Prepared in cooperation with the White Bear Lake Conservation District, Minnesota Pollution Control Agency, Minnesota Department of Natural Resources, Minnesota Board of Water and Soil Resources, Twin Cities Metropolitan Council, and the Groundwater/Surface-Water Interaction Partners

\title{
Groundwater and Surface-Water Interactions near White Bear Lake, Minnesota, through 2011
}
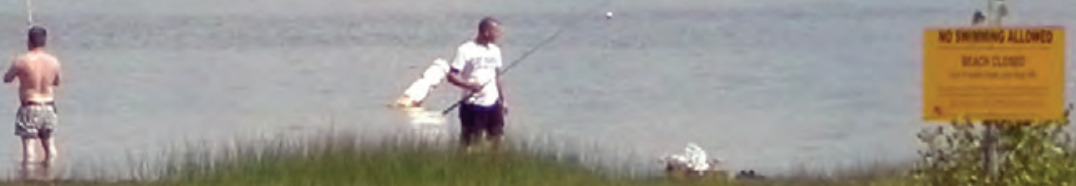

Scientific Investigations Report 2013-5044

U.S. Department of the des. 4.S. Geological survey 
Cover. White Bear Lake at Ramsey County beach, August 7, 2011 (photograph by Perry M. Jones, U.S. Geological Survey). 


\section{Groundwater and Surface-Water Interactions near White Bear Lake, Minnesota, through 2011}

By Perry M. Jones, Jared J. Trost, Donald O. Rosenberry, P. Ryan Jackson, Jenifer A. Bode, and Ryan M. O'Grady

Prepared in cooperation with the White Bear Lake Conservation District, Minnesota Pollution Control Agency, Minnesota Department of Natural Resources, Minnesota Board of Water and Soil Resources, Twin Cities Metropolitan Council, and the Groundwater/Surface-Water Interaction Partners

Scientific Investigations Report 2013-5044 


\title{
U.S. Department of the Interior SALLY JEWELL, Secretary
}

\section{U.S. Geological Survey Suzette M. Kimball, Acting Director}

\author{
U.S. Geological Survey, Reston, Virginia: 2013
}

For more information on the USGS - the Federal source for science about the Earth, its natural and living resources, natural hazards, and the environment, visit http://www.usgs.gov or call 1-888-ASK-USGS.

For an overview of USGS information products, including maps, imagery, and publications, visit http://www.usgs.gov/pubprod

To order other USGS information products, visit http://store.usgs.gov

Any use of trade, firm, or product names is for descriptive purposes only and does not imply endorsement by the U.S. Government.

Although this information product, for the most part, is in the public domain, it also may contain copyrighted materials as noted in the text. Permission to reproduce copyrighted items must be secured from the copyright owner.

Suggested citation:

Jones, P.M., Trost, J.J., Rosenberry, D.O., Jackson, P.R., Bode, J.A., and O'Grady, R.M., 2013, Groundwater and surface-water interactions near White Bear Lake, Minnesota, through 2011: U.S. Geological Survey Scientific Investigations Report 2013-5044, 73 p. 


\section{Contents}

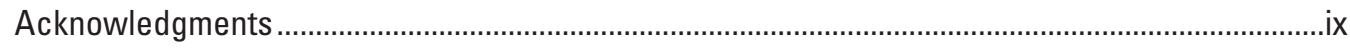

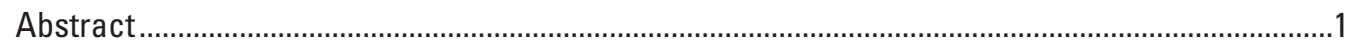

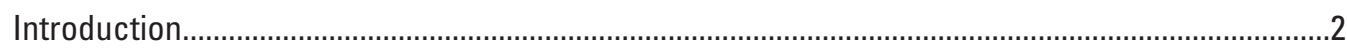

Purpose and Scope .................................................................................................

Description of Study Area, Hydrology, and Hydrogeology ...................................................

Previous Investigations.....................................................................................................

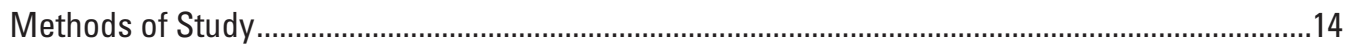

Historical Hydrologic Data ......................................................................................... 14

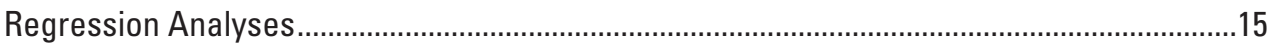

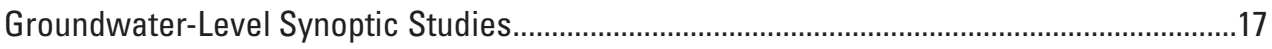

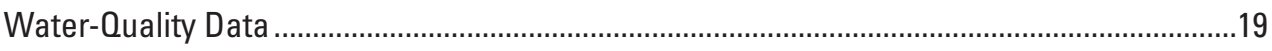

Autonomous, Underwater Vehicle Survey ……………................................................19

Lake-Sediment Temperature Surveys ......................................................................20

Water-Quality Sample Collection, Handling, Analysis, and Quality Control ...................21

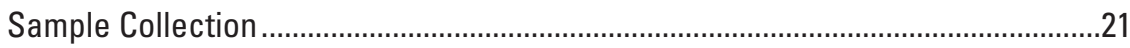

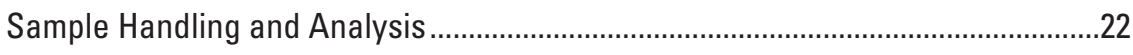

Quality Assurance/Quality Control.........................................................................23

Near-Shore Hydraulic-Head Differences, Seepage Rates, and Lake-Sediment

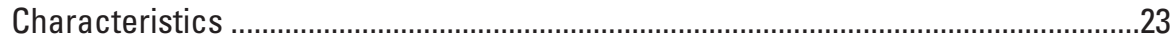

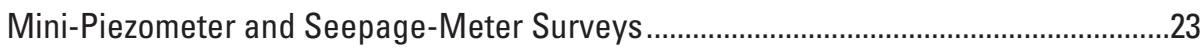

Lake-Sediment Coring/Penetration Probe _.......................................................................24

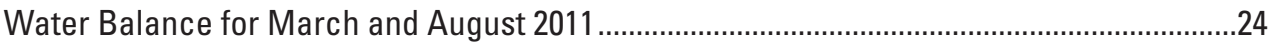

Groundwater and Surface-Water Interactions .............................................................................27

Historical Changes in Lake Level and Volume of White Bear Lake and Their

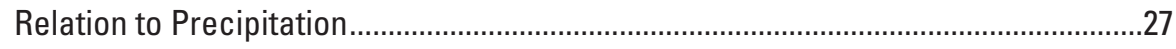

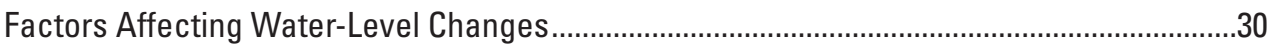

Relations Between Groundwater Levels and Lake Levels ............................................30

Trends in Groundwater Withdrawals .........................................................................31

Relations Between Water-Balance Components, Groundwater Withdrawals, and Water Levels...........................................................................................32

Groundwater Flow and Regional Surface-Water and Groundwater-Level Changes

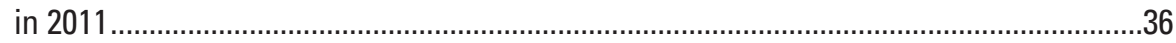

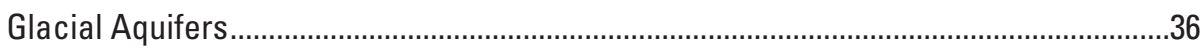

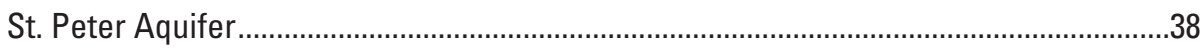

Prairie du Chien-Jordan Aquifer .................................................................................38

Precipitation Effects on 2011 Groundwater Levels ......................................................38

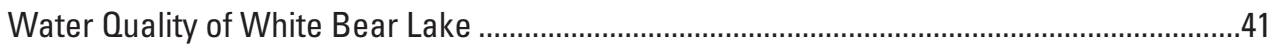

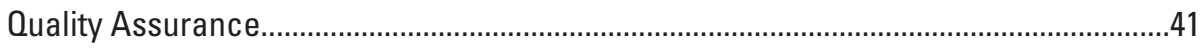

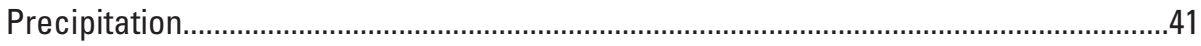

Surface-Water Quality ........................................................................................... 41

Autonomous, Underwater Vehicle Survey ……………………………………......5

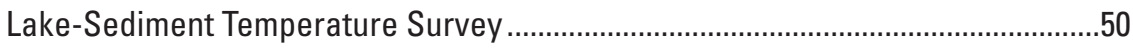

Properties, Major Constituents, and Stable Isotopes...............................................53 


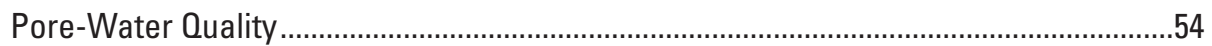

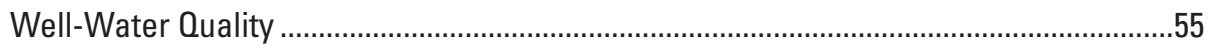

Near-Shore Hydraulic-Head Differences, Seepage Rates, and Lake-Sediment

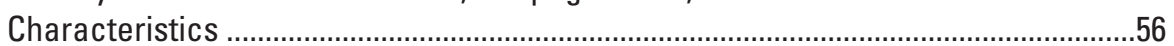

Mini-Piezometer/Seepage-Meter Surveys ..............................................................56

Lake-Sediment Coring/Penetration Probe.......................................................................58

Water Balance for March and August 2011 …….............................................................60

Implications of Groundwater and Surface-Water Interactions ...................................................61

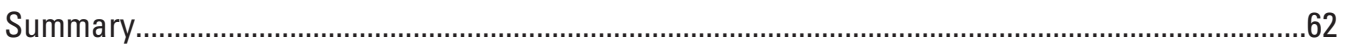

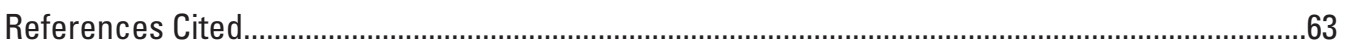

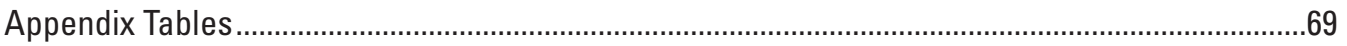

\section{Figures}

1. Map showing location of study area, observation wells, and upper bedrock geology, northeast Twin Cities Metropolitan Area, Minnesota

2. Graphs showing water-level elevations for and annual precipitation and pan-estimated lake-surface evaporation near White Bear Lake, northeast Twin Cities Metropolitan Area, Minnesota.

3. Map showing locations of study sites and lines of equal water depth for White Bear Lake, northeast Twin Cities Metropolitan Area, Minnesota ......................................6

4. Geologic cross section for White Bear Lake, northeast Twin Cities Metropolitan Area, Minnesota 6

5. Map showing locations of wells and lakes where water levels were measured in March/April and August 2011, northeast Twin Cities Metropolitan Area, Minnesota ....18

6. Schematic showing water-balance components for White Bear Lake, northeast Twin Cities Metropolitan Area, Minnesota.

7. Graphs showing analysis of lake-level and precipitation data for White Bear Lake, northeast Twin Cities Metropolitan Area, Minnesota

8. Graph showing water-level elevations for White Bear Lake, northeast Twin Cities Metropolitan Area, Minnesota, and Minnesota Department of Natural Resources observation wells open to either the glacial aquifers or the Prairie du Chien-Jordan aquifer, 1980-2011

9. Graphs showing groundwater withdrawals by high-capacity wells near White Bear Lake, northeast Twin Cities Metropolitan Area, Minnesota .....

10. Map showing potentiometric surface of the glacial water-table aquifer and lake levels in the northeast Twin Cities Metropolitan Area, Minnesota, March/April 2011

11. Map showing potentiometric surface of the Prairie du Chien-Jordan aquifer in the northeast Twin Cities Metropolitan Area, Minnesota, March/April 2011

12. Map showing groundwater-level changes in the Prairie du Chien-Jordan aquifer in the northeast Twin Cities Metropolitan Area, Minnesota, between March/April and August 2011

13. Graphs showing comparison of oxygen-18/oxygen-16 ratios and deuterium/protium ratios for snow, bulk precipitation, surface water, well water, and pore water sampled at or near White Bear Lake with meteoric waterline for snow and bulk precipitation, White Bear Lake evaporation trend line, and groundwater/lake-water isotope mixing model for White Bear Lake area. 
14. Maps and vertical profiles showing water-quality anomalies and vertical profiles measured in White Bear Lake, northeast Twin Cities Metropolitan Area, Minnesota, July 11-14, 2011

15. Map showing lake-sediment temperatures, hydraulic-head differences, and seepage-meter median flux rates along the shore of White Bear Lake, Goose Lake, and Bald Eagle Lake, northeast Twin Cities Metropolitan Area, Minnesota, July through September 2011

16. Map showing oxygen-18/oxygen-16 ratios and deuterium/protium ratios and percentage contribution from groundwater and surface water for well-water samples near White Bear Lake, northeast Twin Cities Metropolitan Area, Minnesota

\section{Tables}

1. Geologic units in the White Bear Lake area, northeast Twin Cities Metropolitan Area, Minnesota

2. Number of wells and lakes where water levels were measured in synoptic studies in the White Bear Lake area in March/April and August 2011, northeast Twin Cities Metropolitan Area, Minnesota...

3. Summary of autonomous, underwater vehicle survey missions completed on White Bear Lake, northeast Twin Cities Metropolitan Area, Minnesota, July $11-14,2011$

4. Summaries of linear regression models between annual changes in lake level or volume and precipitation for White Bear Lake, northeast Twin Cities Metropolitan Area, Minnesota, 1978-2011

5. Cumulative precipitation, evaporation, lake-level change, and groundwater withdrawals for three periods between 1980 and 2010, northeast Twin Cities Metropolitan Area, Minnesota

6. Total annual and seasonal municipal groundwater withdrawals in 1980, 1990, 2000, and 2010 for the municipalities of Centerville, Columbus, Forest Lake, Hugo, Lino Lakes, Mahtomedi, North St. Paul, Vadnais Heights, White Bear Lake, and White Bear Township, northeast Twin Cities Metropolitan Area, Minnesota...

7. Summary of quality-assurance data for sequential replicate samples and equipment blank samples collected at or near White Bear Lake, northeast Twin Cities Metropolitan Area, Minnesota, July through October 2011.

8. Water-quality data for lake water, groundwater, and pore water collected at or near White Bear Lake, northeast Twin Cities Metropolitan Area, Minnesota, July through September 2011

9. Water-quality data for precipitation, lake water, groundwater, and pore water collected at or near White Bear Lake, northeast Twin Cities Metropolitan Area, Minnesota, November 2010 through September 2011

10. Lithology of lake-sediment core collected from White Bear Lake, northeast Twin Cities Metropolitan Area, Minnesota

11. Penetration-probe measurements for lake sediments from White Bear Lake, northeast Twin Cities Metropolitan Area, Minnesota

12. Monthly water balance for March and August 2011 for White Bear Lake, northeast Twin Cities Metropolitan Area, Minnesota 


\section{Appendix Tables}

1-1. Summaries of analysis of covariance models used for estimating annual lake-level changes for White Bear Lake, northeast Twin Cities Metropolitan Area, Minnesota

1-2. Summaries of analysis of covariance models used for estimating annual or seasonal lake-volume changes for White Bear Lake, northeast Twin Cities Metropolitan Area, Minnesota.

1-3. Summaries of multiple linear regression models used for estimating annual changes in level or volume of White Bear Lake and estimating annual and seasonal groundwater withdrawals from the Prairie du Chien-Jordan aquifer in the northeast Twin Cities Metropolitan Area, Minnesota

1-4. Analysis of variance table comparing the sequential addition of explanatory variables used to explain annual lake-volume change, White Bear Lake, northeast Twin Cities Metropolitan Area, Minnesota, 1980-2010.

1-5. Groundwater-level data collected during synoptic studies in March/April 2011, northeast Twin Cities Metropolitan Area, Minnesota

1-6. Groundwater-level data collected during synoptic studies in August 2011, northeast Twin Cities Metropolitan Area, Minnesota

1-7. Surface-water-level data collected by Minnesota Department of Natural Resources during synoptic studies in March/April 2011, northeast Twin Cities Metropolitan Area, Minnesota .....

1-8. Surface-water-level data collected by Minnesota Department of Natural Resources during synoptic studies in August 2011, northeast Twin Cities Metropolitan Area, Minnesota .

1-9. Temperature measurements made in surface water and lake sediment of White Bear Lake, northeast Twin Cities Metropolitan Area, Minnesota, July through August 2011

1-10. Seepage flux measurements and hydraulic-head measurements on the shore of White Bear Lake, northeast Twin Cities Metropolitan Area, Minnesota, 2011 


\section{Conversion Factors and Datums}

Inch/Pound to SI

\begin{tabular}{|c|c|c|}
\hline Multiply & By & To obtain \\
\hline \multicolumn{3}{|c|}{ Length } \\
\hline inch (in.) & 2.54 & centimeter $(\mathrm{cm})$ \\
\hline inch (in.) & 25,400 & micrometer $(\mu \mathrm{m})$ \\
\hline foot $(\mathrm{ft})$ & 0.3048 & meter $(\mathrm{m})$ \\
\hline mile (mi) & 1.609 & kilometer $(\mathrm{km})$ \\
\hline \multicolumn{3}{|c|}{ Area } \\
\hline acre & 4,047 & square meter $\left(\mathrm{m}^{2}\right)$ \\
\hline acre & 0.4047 & hectare (ha) \\
\hline square foot $\left(\mathrm{ft}^{2}\right)$ & 0.09290 & square meter $\left(\mathrm{m}^{2}\right)$ \\
\hline square mile $\left(\mathrm{mi}^{2}\right)$ & 259.0 & hectare (ha) \\
\hline square mile $\left(\mathrm{mi}^{2}\right)$ & 2.590 & square kilometer $\left(\mathrm{km}^{2}\right)$ \\
\hline \multicolumn{3}{|c|}{ Volume } \\
\hline ounce, fluid (fl. oz) & 29.57 & milliliter $(\mathrm{mL})$ \\
\hline gallon (gal) & 3.785 & liter $(\mathrm{L})$ \\
\hline gallon (gal) & 0.003785 & cubic meter $\left(\mathrm{m}^{3}\right)$ \\
\hline gallon (gal) & 3.785 & cubic decimeter $\left(\mathrm{dm}^{3}\right)$ \\
\hline million gallons (Mgal) & 3,785 & cubic meter $\left(\mathrm{m}^{3}\right)$ \\
\hline cubic foot $\left(\mathrm{ft}^{3}\right)$ & 0.02832 & cubic meter $\left(\mathrm{m}^{3}\right)$ \\
\hline acre-foot (acre-ft) & 1,233 & cubic meter $\left(\mathrm{m}^{3}\right)$ \\
\hline \multicolumn{3}{|c|}{ Flow rate } \\
\hline million gallons per year (Mgal/yr) & 3,785 & cubic meter per year $\left(\mathrm{m}^{3} / \mathrm{yr}\right)$ \\
\hline \multicolumn{3}{|c|}{ Hydraulic conductivity } \\
\hline foot per day (ft/d) & 0.3048 & meter per day $(\mathrm{m} / \mathrm{d})$ \\
\hline
\end{tabular}

Temperature in degrees Celsius $\left({ }^{\circ} \mathrm{C}\right)$ may be converted to degrees Fahrenheit $\left({ }^{\circ} \mathrm{F}\right)$ as follows:

$$
{ }^{\circ} \mathrm{F}=\left(1.8 x^{\circ} \mathrm{C}\right)+32
$$

Temperature in degrees Fahrenheit $\left({ }^{\circ} \mathrm{F}\right)$ may be converted to degrees Celsius $\left({ }^{\circ} \mathrm{C}\right)$ as follows:

$$
{ }^{\circ} \mathrm{C}=\left({ }^{\circ} \mathrm{F}-32\right) / 1.8
$$

Vertical coordinate information is referenced to the North American Vertical Datum of 1988 (NAVD 88) or the National Geodetic Vertical Datum of 1929 (NGVD 29).

Horizontal coordinate information is referenced to the North American Datum of 1983 (NAD 83).

Elevation, as used in this report, refers to distance above the vertical datum.

Specific conductance is given in microsiemens per centimeter at 25 degrees Celsius $(\mu \mathrm{S} / \mathrm{cm}$ at $\left.25^{\circ} \mathrm{C}\right)$.

Concentrations of chemical constituents in water are given either in milligrams per liter (mg/L)or micrograms per liter $(\mu \mathrm{g} / \mathrm{L})$. 


\section{Abbreviations, Acronyms, and Symbols}

$\begin{array}{ll}\text { ANCOVA } & \text { analysis of covariance } \\ \text { AUV } & \text { autonomous underwater vehicle } \\ \text { CORS } & \begin{array}{l}\text { Continuously Operating Reference Station (Minnesota Department of } \\ \text { Transportation) }\end{array} \\ \text { CWI } & \text { Minnesota County Well Index } \\ \text { GIS } & \text { geographic information system } \\ \text { GPS } & \text { global positioning system } \\ \text { LacCore } & \text { National Lacustrine Core Facility } \\ \text { LiDAR } & \text { light detection and ranging } \\ \text { MDNR } & \text { Minnesota Department of Natural Resources } \\ \text { MnDOT } & \text { Minnesota Department of Transportation } \\ \text { NWIS } & \text { National Water Information System (U.S. Geological Survey database) } \\ \text { NWOL } & \text { National Water Quality Laboratory } \\ \text { RTK GPS } & \text { real-time kinematic global positioning system } \\ \text { TCMA } & \text { Twin Cities Metropolitan Area } \\ \text { USGS } & \text { U.S. Geological Survey } \\ > & \text { greater than } \\ < & \text { less than } \\ \pm & \text { plus or minus } \\ \text { B } & \text { registered trademark } \\ \text { TM } & \text { trade mark } \\ & \end{array}$




\section{Acknowledgments}

This report presents a compilation of information supplied by many agencies and individuals. The authors would like to thank the Minnesota Department of Natural Resources, Minnesota Pollution Control Agency, Minnesota Board of Water and Soil Resources, and Metropolitan Council for assistance with field aspects of the study. The authors would like to thank the Groundwater/Surface-water Interaction Partners, a group of State, county, municipal, and regional planning agencies, watershed organizations, and private organizations concerned about White Bear Lake, for their support for the study. The Groundwater/Surface-water Interaction Partners consisted of the following organizations: White Bear Lake Conservation District, Minnesota Department of Natural Resources, Minnesota Pollution Control Agency, Minnesota Board of Water and Soil Resources, Metropolitan Council, Washington County Public Health and Environment, Ramsey County Public Works, the city of White Bear Lake, the city of Mahtomedi, the city of Birchwood Village, the city of Dellwood, White Bear Township, Rice Creek Watershed District, Vadnais Lake Area Water Management Organization, White Bear Lake Home Owners Association, and the Veterans of Foreign Wars of White Bear Lake, Post 1782.

The authors would like to thank property owners around White Bear Lake for providing access to the lake through their property.

The authors would like to thank Dr. Kerry Keen, University of Wisconsin-River Falls, for assistance with data analysis and field aspects of the study.

Abigail Tomasek, Erich Kessler, Josh Ayers, Aliesha Diekoff, Michael Menheer, Andrew Berg, and David Dupre of the U.S. Geological Survey are acknowledged for assistance with office and field aspects of the study. Melinda Erickson and Briant Kimball of the U.S. Geological Survey are acknowledged for their technical reviews of the report. 



\title{
Groundwater and Surface-Water Interactions near White Bear Lake, Minnesota, through 2011
}

\author{
By Perry M. Jones ${ }^{1}$, Jared J. Trost', Donald 0. Rosenberry' ${ }^{1}$ P. Ryan Jackson' ${ }^{1}$, Jenifer A. Bode ${ }^{1}$, and \\ Ryan M. O'Grady²
}

\section{Abstract}

The U.S. Geological Survey, in cooperation with the White Bear Lake Conservation District, the Minnesota Pollution Control Agency, the Minnesota Department of Natural Resources, and other State, county, municipal, and regional planning agencies, watershed organizations, and private organizations, conducted a study to characterize groundwater and surface-water interactions near White Bear Lake through 2011. During 2010 and 2011, White Bear Lake and other lakes in the northeastern part of the Twin Cities Metropolitan Area were at historically low levels. Previous periods of lower water levels in White Bear Lake correlate with periods of lower precipitation; however, recent urban expansion and increased pumping from the Prairie du Chien-Jordan aquifer have raised the question of whether a decline in precipitation is the primary cause for the recent water-level decline in White Bear Lake. Understanding and quantifying the amount of groundwater inflow to a lake and water discharge from a lake to aquifers is commonly difficult but is important in the management of lake levels. Three methods were used in the study to assess groundwater and surface-water interactions on White Bear Lake: (1) a historical assessment (1978-2011) of levels in White Bear Lake, local groundwater levels, and their relation to historical precipitation and groundwater withdrawals in the White Bear Lake area; (2) recent (2010-11) hydrologic and water-quality data collected from White Bear Lake, other lakes, and wells; and (3) water-balance assessments for White Bear Lake in March and August 2011.

An analysis of covariance between average annual lake-level change and annual precipitation indicated the relation between the two variables was significantly different from 2003 through 2011 compared with 1978 through 2002, requiring an average of 4 more inches of precipitation per year to maintain the lake level. This shift in the linear relation between annual lake-level change and annual precipitation indicated the net effect of the non-precipitation terms on the water balance has changed relative to precipitation. The

\footnotetext{
${ }^{1}$ U.S. Geological Survey.
}

${ }^{2}$ University of Minnesota. average amount of precipitation required each year to maintain the lake level has increased from 33 inches per year during 1978-2002 to 37 inches per year during 2003-11. The combination of lower precipitation and an increase in groundwater withdrawals can explain the change in the lake-level response to precipitation. Annual and summer groundwater withdrawals from the Prairie du Chien-Jordan aquifer have more than doubled from 1980 through 2010. Results from a regression model constructed with annual lake-level change, annual precipitation minus evaporation, and annual volume of groundwater withdrawn from the Prairie du Chien-Jordan aquifer indicated groundwater withdrawals had a greater effect than precipitation minus evaporation on water levels in the White Bear Lake area for all years since 2003. The recent (2003-11) decline in White Bear Lake reflects the declining water levels in the Prairie du Chien-Jordan aquifer; increases in groundwater withdrawals from this aquifer are a likely cause for declines in groundwater levels and lake levels.

Synoptic, static groundwater-level and lake-level measurements in March/April and August 2011 indicated groundwater was potentially flowing into White Bear Lake from glacial aquifers to the northeast and south, and lake water was potentially discharging from White Bear Lake to the underlying glacial and Prairie du Chien-Jordan aquifers and glacial aquifers to the northwest. Groundwater levels in the Prairie du Chien-Jordan aquifer below White Bear Lake are approximately 0 to 19 feet lower than surface-water levels in the lake, indicating groundwater from the aquifer likely does not flow into White Bear Lake, but lake water may discharge into the aquifer. Groundwater levels from March/April to August 2011 declined more than 10 feet in the Prairie du Chien-Jordan aquifer south of White Bear Lake and to the north in Hugo, Minnesota.

Water-quality analyses of pore water from nearshore lake-sediment and well-water samples, seepage-meter measurements, and hydraulic-head differences measured in White Bear Lake also indicated groundwater was potentially flowing into White Bear Lake from shallow glacial aquifers to the east and south. Negative temperature anomalies determined in shallow waters in the water-quality survey conducted in White Bear Lake indicated several shallow-water areas 
where groundwater may be flowing into the lake from glacial aquifers below the lake. Cool lake-sediment temperatures (less than 18 degrees Celsius) were measured in eight areas along the northeast, east, south, and southwest shores of White Bear Lake, indicating potential areas where groundwater may flow into the lake.

Stable isotope analyses of well-water, precipitation, and lake-water samples indicated wells downgradient from White Bear Lake screened in the glacial buried aquifer or open to the Prairie du Chien-Jordan aquifer receive a mixture of surface water and groundwater; the largest surface-water contributions are in wells closer to White Bear Lake. A wide range in oxygen-18/oxygen-16 and deuterium/protium ratios was measured in well-water samples, indicating different sources of water are supplying water to the wells. Well water with oxygen-18/ oxygen-16 and deuterium/protium ratios that plot close to the meteoric water line consisted mostly of groundwater because deuterium/protium ratios for most groundwater usually are similar to ratios for rainwater and snow, plotting close to meteoric water lines. Well water with oxygen-18/oxygen-16 and deuterium/protium ratios that plot between the meteoric water line and ratios for the surface-water samples from White Bear Lake consists of a mixture of surface water and groundwater; the percentage of each source varies relative to its ratios. White Bear Lake is the likely source of the surface water to the wells that have a mixture of surface water and groundwater because (1) it is the only large, deep lake near these wells; (2) these wells are near and downgradient from White Bear Lake; and (3) these wells obtain their water from relatively deep depths, and White Bear Lake is the deepest lake in that area. The percentages of surface-water contribution to the three wells screened in the glacial buried aquifer receiving surface water were 16,48 , and 83 percent. The percentages of surface-water contribution ranged from 5 to 79 percent for the five wells open to the Prairie du Chien-Jordan aquifer receiving surface water; wells closest to White Bear Lake had the largest percentages of surface-water contribution. Water-balance analysis of White Bear Lake in March and August 2011 indicated a potential discharge of 2.8 and 4.5 inches per month, respectively, over the area of the lake from the lake to local aquifers. Most of the sediments from a 12.4-foot lake core collected at the deepest part of White Bear Lake consisted of silts, sands, and gravels likely slumped from shallower waters, with a very low amount of low-permeability, organic material.

\section{Introduction}

White Bear Lake and other lakes in Ramsey and Washington Counties in the northeastern part of the Twin Cities Metropolitan Area (TCMA; fig. 1) are at historically low levels. As of June 21, 2012, the water level in White Bear Lake was 921.12 feet (ft) above the North American Vertical Datum of 1988 (NAVD 88), $4.23 \mathrm{ft}$ below the ordinary highwater level, and $1.33 \mathrm{ft}$ above the lowest recorded water level on November 13, 2010 (Minnesota Department of Natural Resources, 2012). Since 1924, water levels in the lake have ranged from 927.15 to $919.79 \mathrm{ft}$ above NAVD 88; periods of low water levels were measured during 1924-1939, 19881993, and 2008-11 (fig. 2; Minnesota Department of Natural Resources, 2012). Other lakes in Ramsey and Washington Counties at low levels include Birch, Mann, South School Section, and Sunset Lakes (fig. 1) (Minnesota Department of Natural Resources, 2012). The low water levels in White Bear Lake have resulted in the closure of a county beach for 4 years and limitation of boat access to the lake through local marinas and lakefront properties.

The recent (2003-11) water-level decline in White Bear Lake may be the result of lower precipitation, lower amounts of groundwater discharge to the lake, or increased amounts of lake-water discharge to aquifers than during previous years. Groundwater levels in glacial and bedrock aquifers declined between 2005 and 2011 near White Bear Lake (Minnesota Department of Natural Resources, 2011a) and correlated with the lake-level decline that began in 2003. These groundwaterlevel declines can result in a decrease in rates of groundwater flow to the lake and an increase in water discharge from the lake to the local aquifers.

Historically, periods of low water levels in White Bear Lake correspond with periods of low precipitation (fig. 2). However, recent urban expansion and associated activities in Ramsey and Washington Counties have put into question whether a decline in precipitation is the primary cause for the recent water-level decline in White Bear Lake. Groundwater withdrawals and routing of surface water out of the watershed, which are associated with recent urban expansion, have increased north of White Bear Lake (Minnesota Department of Natural Resources, 2011b). An increase in groundwater withdrawals within the groundwater watershed for White Bear Lake could reduce groundwater levels and seepage into the lake. Routing of surface water out of the watershed could reduce the amount of leakage or recharge to local groundwater systems, reducing groundwater levels and seepage into the lake.

An understanding of the lake water balance and the lakelevel response to changes in water-balance variables is needed to assess the effectiveness of any water-level augmentation plan. Local government agencies and residents are concerned that low water levels in White Bear Lake may be long-term and affect the local economy with the limitation of water access to beaches and marinas. To increase water levels, local government agencies and residents are considering augmenting the lake level of White Bear Lake by pumping water from local bedrock wells or by diverting surface water from the Mississippi River through a chain of lakes to White Bear Lake. Groundwater was pumped from bedrock aquifers into the lake to augment water levels during periods of low water levels from the early 1900's to 1977 (Minnesota Department of Natural Resources, 1998). To address these concerns and questions, the U.S. Geological Survey (USGS), in cooperation with the White Bear Lake Conservation District, the Minnesota Pollution Control Agency, the Minnesota Department of 


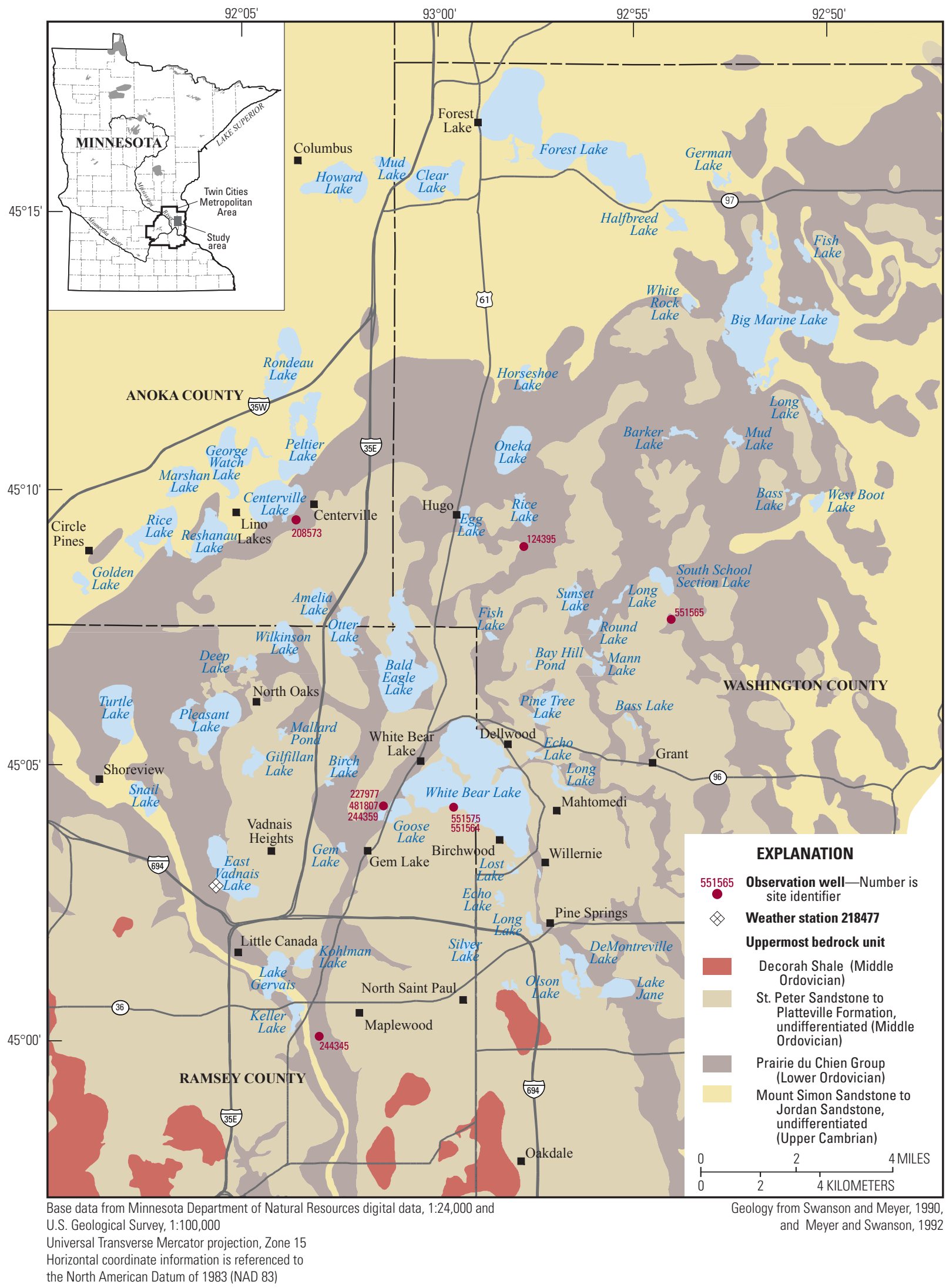

Figure 1. Location of study area, observation wells, and upper bedrock geology, northeast Twin Cities Metropolitan Area, Minnesota. 
A. Water-level elevations for White Bear Lake, 1924-2011

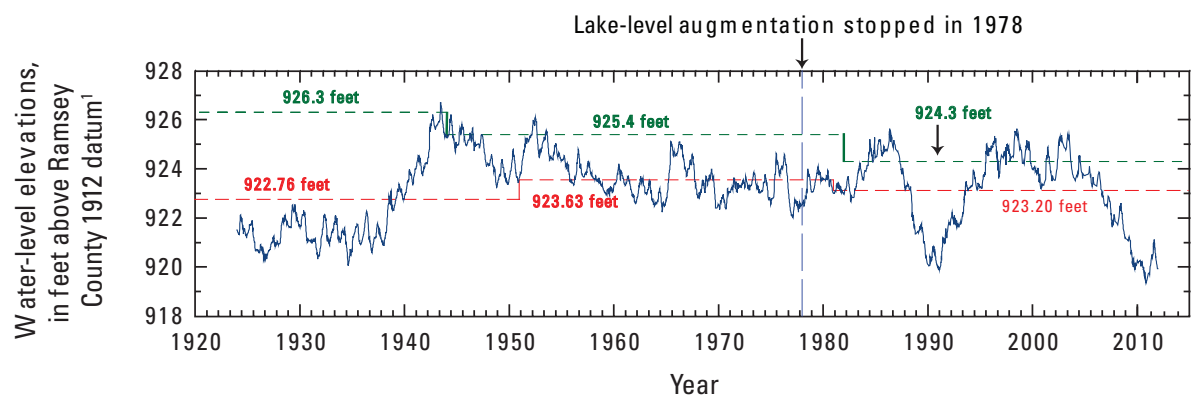

B. Annual precipitation near White Bear Lake, 1924-2011

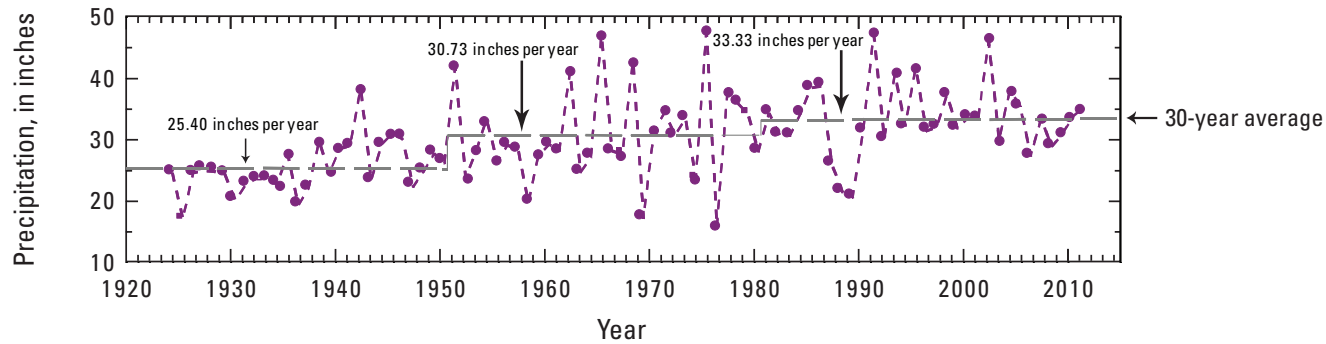

C. Water-level elevations for White Bear Lake, 1978-2011

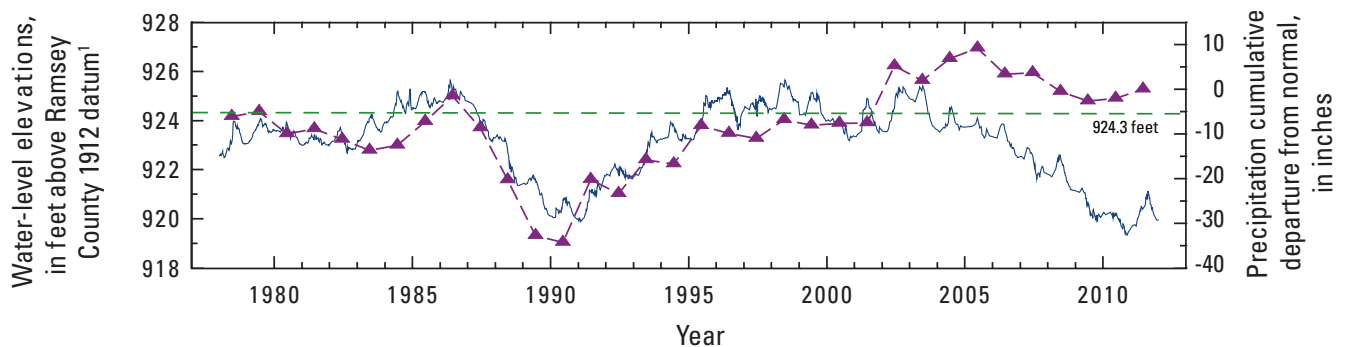

D. Annual precipitation and pan-estimated lake-surface evaporation near White Bear Lake, 1978-2011

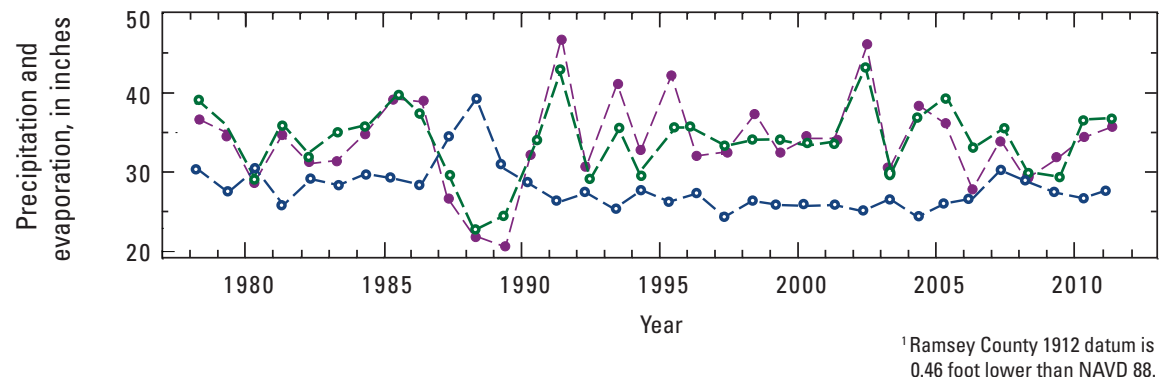

EXPLANATION

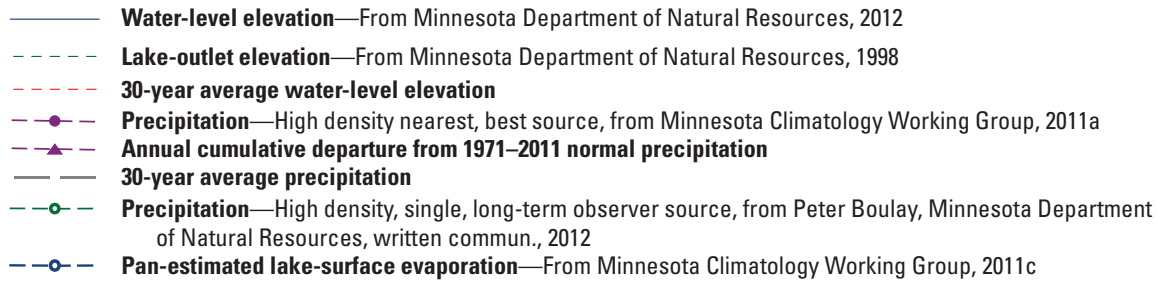

Figure 2. Water-level elevations for and annual precipitation and pan-estimated lake-surface evaporation near White Bear Lake, northeast Twin Cities Metropolitan Area, Minnesota. $A$, Water-level elevations,1924-2011; B, Annual precipitation, 1924-2011; C, Water-level elevations, 1978-2011; and D, Annual precipitation and pan-estimated lake-surface evaporation, 1978-2011. 
Natural Resources (MDNR), and the Groundwater/Surfacewater Interaction Partners (described in the "Acknowledgments" section), completed a study to evaluate groundwater and surface-water interactions near White Bear Lake.

Lakes with small watershed-to-lake area ratios and no major surface-water inlets or outlets during low lake levels, such as White Bear Lake, depend on a hydrologic balance between precipitation, evaporation, and groundwater inflow and lake-water discharge to aquifers to maintain water levels (Horne and Goldman, 1994). Rainfall contributes water to the lake as direct rainfall on the lake surface, recharge to the local groundwater systems that eventually seeps into the lake, and runoff from the land surface and from local storm sewer systems. Snowmelt in the spring contributes water to the lake through runoff from the land surface and local storm sewers and recharges the local groundwater system. Field studies in Wisconsin, Minnesota, and Nebraska indicate lakes with small watersheds can receive groundwater from shallow flow systems that extend far beyond their surface watershed and can also receive groundwater from deeper aquifers (Winter and others, 2003). Residents and local divers swimming in White Bear Lake have reported cool waters indicative of groundwater inflow to the lake (Donahower, 1994).

The amount of groundwater inflow to a lake and lakewater discharge from a lake to aquifers is usually difficult to understand and quantify but is needed to manage lake levels and assess any water-level augmentation plan. The amount of groundwater inflow to a lake and lake-water discharge to aquifers depends on the permeability of sediments from which groundwater is entering or water is leaving a lake and the hydraulic gradient between the groundwater system and lake (Winter and others, 1998). Groundwater inflow to and water discharge from a lake can be estimated directly by measuring water seepage into and out of the lake or indirectly by measuring the permeability of and water levels in lake sediments and aquifer materials surrounding the lake (Rosenberry and LaBaugh, 2008). Measurements of groundwater levels and lake levels also can be used to delineate the groundwater watershed for a lake, determining sources of groundwater that enter a lake. Differences in water temperatures and other water-quality characteristics along the lake shoreline can be used with measurements of pore water and lake level to identify locations of springs and areas where groundwater is flowing into a lake (Jones, 2006; Rosenberry and LaBaugh, 2008).

\section{Purpose and Scope}

This report describes the assessment of groundwater and surface-water interactions near White Bear Lake using three different methods. The three methods summarized to assess groundwater and surface-water interactions on White Bear Lake are (1) a historical assessment (1978-2011) of White Bear Lake levels, local groundwater levels, and their relation to historical precipitation and groundwater withdrawals in the White Bear Lake area; (2) an assessment of recent (2010-11) hydrologic and water-quality data collected from White Bear Lake, other lakes, and wells used to assess groundwater and surface-water interactions near White Bear Lake; and (3) monthly water-balance assessments for White Bear Lake in March and August 2011.

Existing precipitation, groundwater-level, and lake-level data collected from 1978 through 2011 were analyzed to gain a basic understanding of precipitation/groundwater relations to the water level of the lake and assess potential causes for the recent (2003-11) water-level decline in White Bear Lake. Groundwater levels in existing wells and water levels in White Bear Lake and nearby lakes were measured in March/April and August 2011 to determine groundwater levels and watershed-scale groundwater flow directions in the glacial aquifers, the St. Peter Sandstone aquifer, and the Prairie du Chien-Jordan aquifer. A localized, detailed assessment of groundwater flow into White Bear Lake was completed in 2011 using three techniques: (1) a temperature survey of the lake shoreline to determine areas of groundwater inflow, (2) mini-piezometer surveys along the lakeshore and deeper parts of the lake to collect hydraulic-head data and water-quality samples to confirm groundwater inflow, and (3) seepage-meter surveys along the lakeshore to collect water-flow data into and out of the lake. A series of surface-water, rainwater, and snow samples were collected from White Bear Lake and nearby lakes to determine if surface-runoff/snowmelt contributions to the lake can be determined from major constituents and isotopic signatures of the lake water and snow. Water balances were computed for the months of March and August 2011 using precipitation and evaporation data collected by State and local agencies and using groundwater-level and groundwater-flow data collected as part of this study.

\section{Description of Study Area, Hydrology, and Hydrogeology}

White Bear Lake is in the gently rolling, glaciated landscape of western Ramsey and eastern Washington Counties in the northeastern part of the TCMA (fig. 1). The lake is the third largest lake in the TCMA. The cities of White Bear Lake, Birchwood, Mahtomedi, and Dellwood, and the township of White Bear are located along the lakeshore. White Bear Lake is part of a chain of lakes that formed from the melting of glacial ice blocks lodged in bedrock valleys (Meyer and Swanson, 1992). The origin of the name "White Bear Lake" comes from a Native American legend where a Chippewa brave fought a great white bear for the protection of his Sioux maiden (Thayer 1883). The lake consists of three main bays divided by Manitou Island, which is in the west-central part of the lake, and a peninsula that stretches from the east shore of White Bear Lake toward Manitou Island (fig. 3). Land use along the lake shoreline consists of residential and commercial properties in the cities of White Bear Lake and Mahtomedi and small municipal and private beaches. The lake is used extensively for recreation, including fishing, boating, and swimming. 


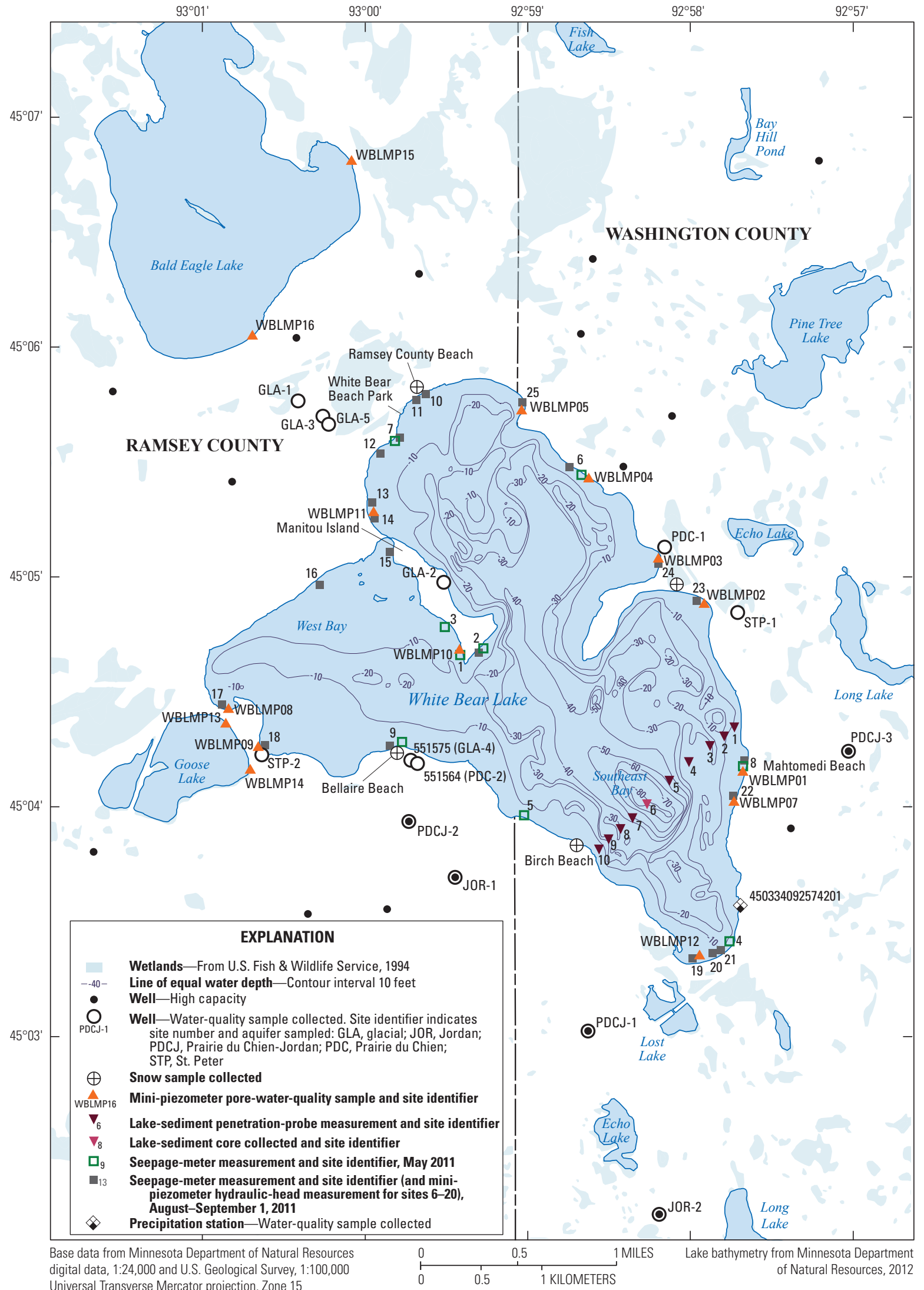

Universal Transverse Mercator projection, Zone 15

Horizontal coordinate information is referenced to

the North American Datum of 1983 (NAD 83)

Figure 3. Locations of study sites and lines of equal water depth for White Bear Lake, northeast Twin Cities Metropolitan Area, Minnesota. 
Ramsey County Beach is a large county beach along the northwest shore of White Bear Lake (fig. 3) that was closed to swimmers during 2008 through 2012. Land use in the watershed consists mainly of residential, agricultural, and open space.

The watershed for White Bear Lake is dominated by high- to low-developed urban lands with areas of evergreen and deciduous forest to the west and a mixture of urban lands, pasture, croplands, and evergreen and deciduous forest to the east. White Bear Lake is in the western part of the St. PaulBaldwin Plains and Moraines Ecological Subsection of the Eastern Broadleaf Forest Province of Minnesota (Minnesota Department of Natural Resources, 2011c), which is dominated by the St. Croix Moraine and areas of outwash. Shrub and wooded swamps commonly attached to lakes are present in the northern and eastern parts of the lake watershed. Eurasian water milfoil and the Eurasian and Northern milfoil hybrid are the most common aquatic plants in White Bear Lake (McComas and Stuckert, 2009).

The climate of White Bear Lake is continental, with cold winters and warm summers. The mean air temperature in July for the Minneapolis/St. Paul International Airport, Minnesota, is about 73.8 degrees Fahrenheit $\left({ }^{\circ} \mathrm{F}\right)$; the mean air temperature in January is about $15.6^{\circ} \mathrm{F}$ (National Climatic Data Center, 2013). Mean annual precipitation (1981-2010) is about 30.6 inches (in.) (National Climatic Data Center, 2013).

White Bear Lake is one of the largest and deepest lakes in the northeastern part of the TCMA, but its watershed is relatively small. The lake covers approximately 2,100 to 3,100 acres, depending on the water level (Minnesota Department of Natural Resources, 1998). Recent (2011) estimates of the lake and watershed areas are 2,401 and 4,704 acres, respectively (Rice Creek Watershed District, 2011). The watershed-to-lake area ratio (approximately 2:1) is small compared to most lakes in Minnesota. White Bear Lake has a maximum depth of more than $80 \mathrm{ft}$; the deeper depths are in the southeast part of the lake (fig. 3). The lake is a mesotrophic lake, being moderately clear with an intermediate level of productivity (Minnesota Pollution Control Agency, 2011).

White Bear Lake is a closed-basin lake with no major natural surface-water inlets or outlets (rivers or streams). One small ephemeral stream discharges water to the lake along the east shoreline during precipitation events. The only outlet from the lake consists of a channel and culverts at Ramsey County Beach (Minnesota Department of Natural Resources, 1998), where water is discharged to a wetland north of the beach (fig. 3). The outlet elevation is $924.76 \mathrm{ft}$ above NAVD 88 (Minnesota Department of Natural Resources, 1998). Water levels in the lake typically are below the outlet elevation. Thirty-seven storm sewer drains discharge water from local streets and wetlands into the lake. At water levels below the outlet elevation, water leaves White Bear Lake as discharge to surrounding aquifers or evaporation from the lake surface.

Large water-level fluctuations take place in White Bear Lake because of the relatively small watershed for the lake and its status as a closed-basin lake (Minnesota Department of Natural Resources, 1998). Since 1924, water levels in the lake have ranged from 927.15 to $919.79 \mathrm{ft}$ above NAVD 88, with periods of low water levels during 1924-1939, 1988-1993, and 2008-11 (fig. 2). Between 1906 and 2011, lake levels varied by more than $7 \mathrm{ft}$; the lowest level on record, $919.79 \mathrm{ft}$ above NAVD 88, was on November 13, 2010. The water level of White Bear Lake was artificially maintained with groundwater augmentation for most years between the early 1900's and 1977 (Minnesota Department of Natural Resources, 1998). During multi-year droughts, as in the 1930s and 1987-89, the lake level substantially declined (fig. 2).

In Minnesota, lakes with lake-to-watershed area ratios of less than 5 typically have wide ranges of water-level fluctuations, as much as 5 to $10 \mathrm{ft}$ (Minnesota Department of Natural Resources, 1998). Water levels in closed-basin lakes tend to fluctuate more than lakes with outlets under steady-state hydrologic conditions (Almendinger, 1990). Slight shifts in climatic or other hydrologic conditions can change the steady-state water levels in closed-basin lakes by several feet (Almendinger, 1990). Large fluctuations in lake levels have been recorded in other closed-basin lakes in Ramsey and Washington Counties (Brown, 1985, 1986).

A strong correlation exists between temporal variations in water levels of the lake and of local aquifers (Minnesota Department of Natural Resources, 1998), indicating the local groundwater system is an important factor controlling the lake levels. Groundwater inflow to and lake-water discharge from White Bear Lake is from glacial water-table and buried aquifers in Quaternary deposits (fig. 4). Local residents have indicated the presence of cooler waters in lake sediments at many locations along the shore and at deeper depths, indicating potential areas of groundwater inflow. Groundwater inflow to lakes commonly takes place at shallow depths where organic sediment thicknesses are smaller than at deeper depths. Water levels in wells near the lake indicate groundwater from the glacial material flows downward into the St. Peter Sandstone and Prairie du Chien Group, the uppermost bedrock units below the lake (figs. 1 and 4) (Minnesota Department of Natural Resources, 1998; Setterholm, 1991).

The geology of the White Bear Lake area and most of the TCMA consists of Precambrian and Paleozoic bedrock underlying glacial material of pre-Wisconsin and Wisconsin age (figs. 1 and 4; table 1). The Solor Church Formation of Middle Proterozoic age underlies Cambrian and Ordovician sedimentary bedrock of the Twin Cities basin (Meyer and Swanson, 1992; Swanson and Meyer, 1990). The Solor Church Formation consists of reddish-brown shale interbedded with reddishbrown feldspathic sandstone (Morey, 1972). The formation underlies the Mount Simon Sandstone of Upper Cambrian age, which contains the lowermost aquifer of the CambrianOrdovician aquifer system in the TCMA (table 1) (Meyer and Swanson, 1992; Swanson and Meyer, 1990). The lower part of the Mount Simon Sandstone is principally a fine- to coarsegrained sandstone that is moderately to poorly cemented, and the upper part of the Mount Simon Sandstone consists of equal parts of thin beds of siltstone and shale and very fine-grained sandstone (Runkel, Tipping, Alexander, and others, 2003). 


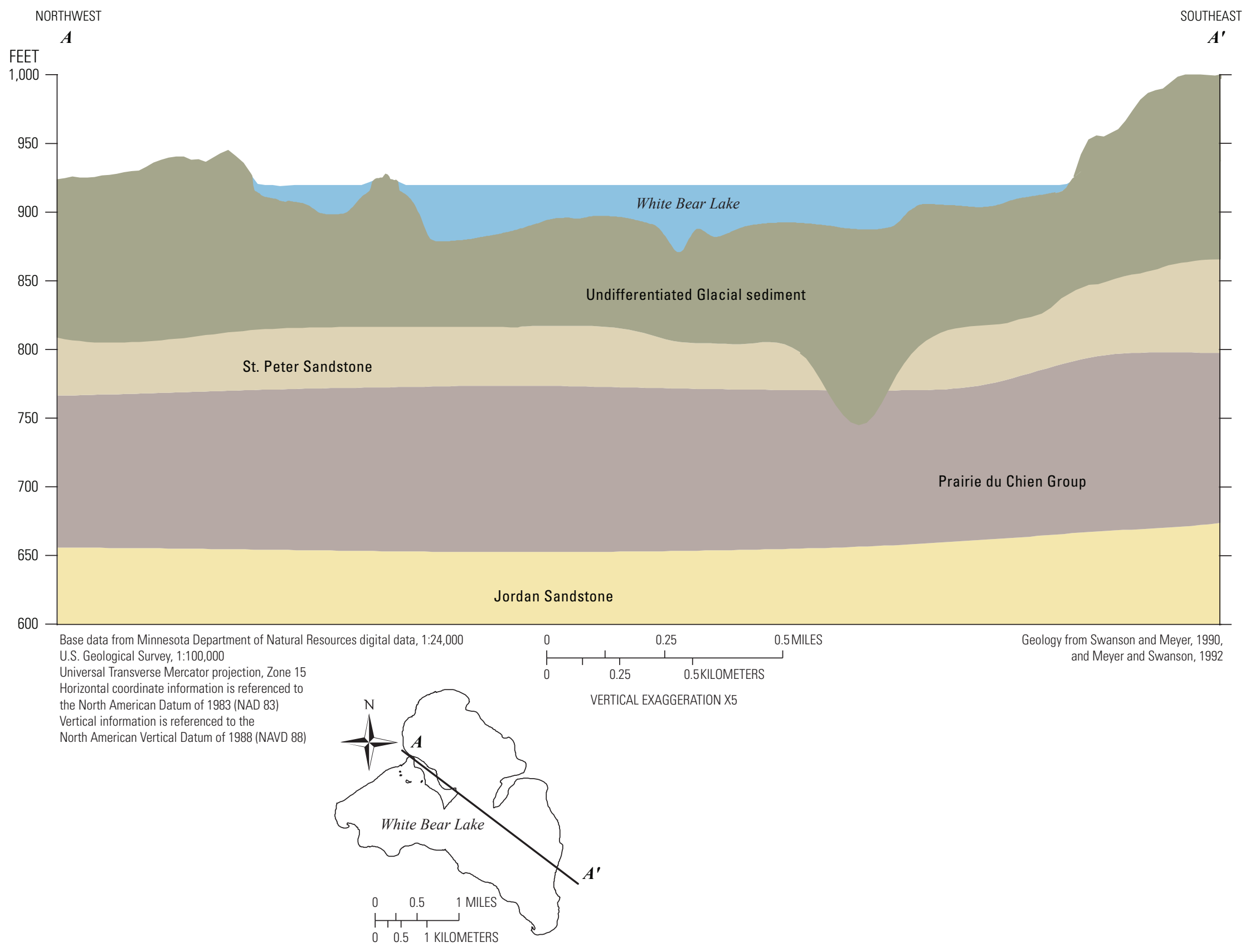

Figure 4. Geologic cross section for White Bear Lake, northeast Twin Cities Metropolitan Area, Minnesota. 
Table 1. Geologic units in the White Bear Lake area, northeast Twin Cities Metropolitan Area, Minnesota.

[Aquifer nomenclature follows the geologic nomenclature of the U.S. Geological Survey. ft/d, feet per day]

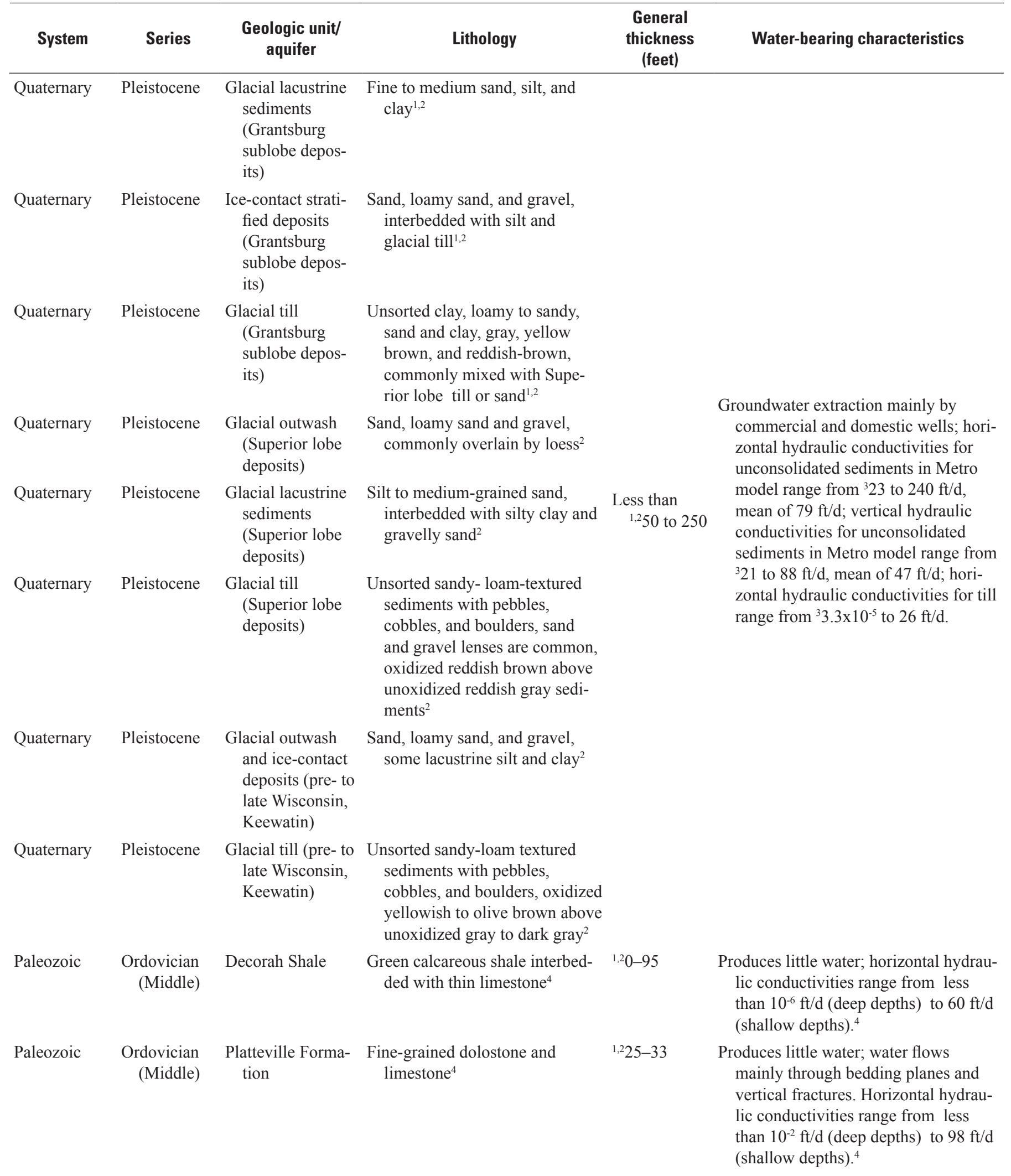


Table 1. Geologic units in the White Bear Lake area, northeast Twin Cities Metropolitan Area, Minnesota.-Continued

[Aquifer nomenclature follows the geologic nomenclature of the U.S. Geological Survey. ft/d, feet per day]

\begin{tabular}{|c|c|c|c|c|c|}
\hline System & Series & $\begin{array}{l}\text { Geologic unit/ } \\
\text { aquifer }\end{array}$ & Lithology & $\begin{array}{l}\text { General } \\
\text { thickness } \\
\text { (feet) }\end{array}$ & Water-bearing characteristics \\
\hline Paleozoic & $\begin{array}{l}\text { Ordovician } \\
\text { (Middle) }\end{array}$ & $\begin{array}{l}\text { Glenwood Forma- } \\
\text { tion }\end{array}$ & Thin, green sandy shale ${ }^{4}$ & $1,23-6$ & $\begin{array}{l}\text { Produces little water; horizontal hydrau- } \\
\text { lic conductivity of } 10^{-2} \mathrm{ft} / \mathrm{d} \text { (shallow } \\
\text { and deep depths). }{ }^{4}\end{array}$ \\
\hline Paleozoic & $\begin{array}{l}\text { Ordovician } \\
\text { (Middle) }\end{array}$ & $\begin{array}{l}\text { St. Peter Sand- } \\
\text { stone (St. Peter } \\
\text { aquifer) }\end{array}$ & $\begin{array}{l}\text { Fine- and medium-grained } \\
\text { sandstone in the upper part, } \\
\text { mudstone, siltstone and shale } \\
\text { interbedded with very coarse } \\
\text { sandstone in the lower part }{ }^{4}\end{array}$ & $1,2146-166$ & $\begin{array}{l}\text { Major aquifer in southeastern Minneso- } \\
\text { ta; horizontal hydraulic conductivities } \\
\text { range from } 10^{-3} \mathrm{ft} / \mathrm{d} \text { to greater than } \\
49 \mathrm{ft} / \mathrm{d} \text {; vertical hydraulic conduc- } \\
\text { tivities range from } 2 \times 10^{-3} \text { to } 92 \mathrm{ft} / \mathrm{d} \text {; } \\
\text { effective porosity ranges from } 0.28 \text { to } \\
0.3 \text {; storativity ranges from } 9 \times 10^{-5} \text { to } \\
9.8 \times 10^{-3} \text {. }\end{array}$ \\
\hline Paleozoic & $\begin{array}{l}\text { Ordovician } \\
\text { (Lower) }\end{array}$ & $\begin{array}{l}\text { Prairie du Chien } \\
\text { Group - Oneota } \\
\text { Dolomite (Prai- } \\
\text { rie du Chien } \\
\text { aquifer) }\end{array}$ & $\begin{array}{l}\text { Thick beds of very fine-grained } \\
\text { dolostone, fine and coarse } \\
\text { clastic interbeds in the lower } \\
\text { part of the formation }{ }^{4}\end{array}$ & $\begin{array}{l}\text { du Chien } \\
\text { Group) }\end{array}$ & $\begin{array}{l}\text { Part of major aquifer in southeastern } \\
\text { Minnesota; horizontal hydraulic } \\
\text { conductivities range from }{ }^{4} 1.5 \times 10^{-4} \text { to } \\
740 \mathrm{ft} / \mathrm{d} \text {; vertical hydraulic con- } \\
\text { ductivities range from }{ }^{4} 1.5 \times 10^{-4} \text { to } \\
10^{-3} \mathrm{ft} / \mathrm{d} \text {; effective porosity of }{ }^{3} 0.06 \text {; } \\
\text { storativity ranges from }{ }^{3} 1.1 \times 10^{-5} \text { to } \\
3.4 \times 10^{-4} \text {. }\end{array}$ \\
\hline Paleozoic & $\begin{array}{l}\text { Cambrian } \\
\text { (Upper) }\end{array}$ & $\begin{array}{l}\text { St. Lawrence } \\
\text { Formation }\end{array}$ & $\begin{array}{l}\text { Interbedded fine clastic (sand- } \\
\text { stone, siltstone, shale) and } \\
\text { carbonate (dolostone) } \text { rock }^{4}\end{array}$ & $1,230-60$ & $\begin{array}{l}\text { Not used as a source of water in the } \\
\text { White Bear Lake area; horizontal } \\
\text { hydraulic conductivities range from } \\
\text { less than }{ }^{3,4} 10^{-2} \text { to } 46 \mathrm{ft} / \mathrm{d} \text {; vertical } \\
\text { hydraulic conductivities range from } \\
3,410^{-4} \text { to } 1.8 \mathrm{ft} / \mathrm{d} \text {; effective porosity } \\
\text { ranges from } 0.15 \text { to } 0.203 \text {. }\end{array}$ \\
\hline Paleozoic & $\begin{array}{l}\text { Cambrian } \\
\text { (Upper) }\end{array}$ & $\begin{array}{l}\text { Tunnel City Group } \\
\text { (formerly Fran- } \\
\text { conia Forma- } \\
\text { tion }^{6} \text { ) }\end{array}$ & $\begin{array}{l}\text { Shale, siltstone, and fine-grained } \\
\text { sandstone with beds of lime- } \\
\text { stone and dolostone }\end{array}$ & 1,2116-166 & $\begin{array}{l}\text { Aquifer in southeastern Minnesota; } \\
\text { horizontal hydraulic conductivities } \\
\text { range from less than }{ }^{3,4} 10^{-3} \text { to } 98 \mathrm{ft} / \mathrm{d} \text {; } \\
\text { vertical hydraulic conductivities } \\
\text { range from }{ }^{3,4} 10^{-4} \text { to } 9.8 \mathrm{ft} / \mathrm{d} \text {. }\end{array}$ \\
\hline
\end{tabular}


Table 1. Geologic units in the White Bear Lake area, northeast Twin Cities Metropolitan Area, Minnesota.—Continued

[Aquifer nomenclature follows the geologic nomenclature of the U.S. Geological Survey. $\mathrm{ft} / \mathrm{d}$, feet per day]

\begin{tabular}{|c|c|c|c|c|c|}
\hline System & Series & $\begin{array}{l}\text { Geologic unit/ } \\
\text { aquifer }\end{array}$ & Lithology & $\begin{array}{l}\text { General } \\
\text { thickness } \\
\text { (feet) }\end{array}$ & Water-bearing characteristics \\
\hline Paleozoic & $\begin{array}{r}\text { Cambrian } \\
\text { (Upper) }\end{array}$ & $\begin{array}{l}\text { Wonewoc Sand- } \\
\text { stone (formerly } \\
\text { the Ironton } \\
\text { and Galesville } \\
\text { Sandstone }{ }^{6} \text { ) }\end{array}$ & $\begin{array}{l}\text { Silty, fine- to coarse-grained } \\
\text { poorly sorted sandstones in the } \\
\text { upper part, fine- to medium- } \\
\text { grained sandstone in the lower } \\
\text { part }^{4}\end{array}$ & $1,242-67$ & $\begin{array}{l}\text { Aquifer in southeastern Minnesota; } \\
\text { horizontal hydraulic conductivities } \\
\text { range from }{ }^{3,4} 0.2 \text { to } 102 \mathrm{ft} / \mathrm{d} \text {; vertical } \\
\text { hydraulic conductivities range from } \\
3,410^{-3} \text { to } 8 \mathrm{ft} / \mathrm{d} \text {; effective porosity } \\
\text { of } 0.253 \text {; storativity ranges from } \\
{ }^{3} 2.7 \times 10^{-5} \text { to } 5.9 \times 10^{-5} \text {. }\end{array}$ \\
\hline Paleozoic & $\begin{array}{r}\text { Cambrian } \\
\text { (Upper) }\end{array}$ & $\begin{array}{l}\text { Eau Claire For- } \\
\text { mation }\end{array}$ & $\begin{array}{l}\text { Siltstone, fine- to medium- } \\
\text { grained glauconitic sand- } \\
\text { stones, and shales }{ }^{4}\end{array}$ & ${ }^{1,2} 63-114$ & $\begin{array}{l}\text { Not used as a source of water in the } \\
\text { White Bear Lake area; horizontal } \\
\text { hydraulic conductivities range from } \\
\text { less than }{ }^{3,4} 10^{-3} \text { to } 0.3 \mathrm{ft} / \mathrm{d} \text {; vertical } \\
\text { hydraulic conductivities range from } \\
3,410^{-4} \text { to } 3 \times 10^{-3} \mathrm{ft} / \mathrm{d} \text {; effective poros- } \\
\text { ity ranges from } 0.28 \text { to } 0.353 \text {. }\end{array}$ \\
\hline Precambrian & $\begin{array}{r}\text { Proterozoic } \\
\text { (Middle) }\end{array}$ & $\begin{array}{l}\text { Solor Church For- } \\
\text { mation of the } \\
\text { Keweenawan } \\
\text { Supergroup }\end{array}$ & $\begin{array}{l}\text { Reddish-brown shale interbed- } \\
\text { ded with reddish-brown } \\
\text { feldspathic sandstone }{ }^{5}\end{array}$ & Unknown & $\begin{array}{l}\text { Not used as a source of water in the } \\
\text { White Bear Lake area; hydraulic } \\
\text { conductivities and other hydrologic } \\
\text { parameters unknown. }\end{array}$ \\
\hline
\end{tabular}

${ }^{1}$ From Meyer and Swanson, 1992.

${ }^{2}$ From Swanson and Meyer, 1990.

${ }^{3}$ From Metropolitan Council, 2012.

${ }^{4}$ From Runkel, Tipping, Alexander, and others, 2003.

${ }^{5}$ From Morey, 1972.

${ }^{6}$ From Mossler, 2008.

Siltstones, fine- to medium-grained glauconitic sandstones, and shales of the Eau Claire Formation of Upper Cambrian age overlie the Mount Simon Sandstone (table 1) (Meyer and Swanson, 1992; Swanson and Meyer, 1990). The formation is 63 to $114 \mathrm{ft}$ thick in Ramsey and Washington Counties (Meyer and Swanson, 1992; Swanson and Meyer, 1990) and commonly is considered a confining unit. However, the formation has been used for water supplies where it is shallow and fractured (Runkel, Tipping, and Mossler, 2003).

The Wonewoc Sandstone [formerly the Ironton and Galesville Sandstones (Mossler, 2008)] of Upper Cambrian age overlies the Eau Claire Formation and is divided into two parts: an upper silty, fine- to coarse-grained, poorly sorted sandstone and lower more sorted, fine- to medium-grained sandstone (table 1) (Meyer and Swanson, 1992; Swanson and Meyer, 1990). The sandstones contain an aquifer used in the TCMA and range from 42 to $67 \mathrm{ft}$ thick in Ramsey and Washington Counties (Meyer and Swanson, 1992; Swanson and Meyer, 1990).
The Tunnel City Group [formerly the Franconia Formation (Mossler, 2008)] of Upper Cambrian age overlies the Wonewoc Sandstone. The group consists of shales, siltstones, and fine-grained sandstones with beds of carbonate strata (table 1) (Runkel, Tipping, Alexander, and others, 2003). The upper member of the group, Mazomanie Member, is a fine- to medium-grained sandstone that is widely used as an aquifer in the TCMA (Runkel and others, 2006). The middle and lower parts of the group consist of low permeability, fine clastic units that are considered a confining unit between the upper member and the Wonewoc Sandstone aquifer.

The St. Lawrence Formation of Upper Cambrian age lies between two formations that contain aquifers used for water supplies: the Jordan Sandstone and the Tunnel City Group (table 1). The St. Lawrence Formation consists of interbeds of the fine clastic and carbonate rocks, mostly sandstones, siltstones, dolostones, and shales (Mossler, 2008). In most of southeastern Minnesota, dolostone is the dominant rock type in the upper part of the formation; clastic sediments dominate 
the lower part (Runkel, Tipping, Alexander, and others, 2003). In the TCMA, the formation is thickest in the southwest, as thick as $90 \mathrm{ft}$, and thins to the northeast (30 to $40 \mathrm{ft}$ thick) (Runkel and others, 2006). Although historically considered a confining unit, recent hydrologic studies of the St. Lawrence Formation found that groundwater can travel at relatively high flow rates through bedding planes and fractures in the formation (Green and others, 2008, 2010; Runkel and others, 2006).

The Jordan Sandstone of Upper Cambrian age consists of coarse to fine clastic sediments, with fractures at various depths below the land surface (table 1) (Runkel, Tipping, Alexander, and others, 2003). Values of hydraulic conductivity for the Jordan aquifer generally are higher and more variable at shallow depths, indicating groundwater flow through fractures is more prevalent at shallow depths (Runkel, Tipping, Alexander, and others, 2003). The Jordan Sandstone is part of the Prairie du Chien-Jordan aquifer, which is a major aquifer used in the White Bear Lake area and the TCMA.

The Prairie du Chien Group, St. Peter Sandstone, Glenwood Formation, Platteville Formation, and Decorah Shale of Ordovician age are the uppermost bedrock units in the White Bear Lake area (figs. 1 and 4; table 1). The Prairie du Chien Group of Lower Ordovician age overlies the Jordan Sandstone and consists of two formations: the Oneota Dolomite and the Shakopee Formation. The Oneota Dolomite is primarily thick beds of very fine-grained dolostone, and fine and coarse clastic interbeds are common in the lower part of the formation (Runkel, Tipping, Alexander, and others, 2003). The overlying Shakopee Formation consists of thin to medium beds of dolostone, shale, and minor amounts of siliciclastic sandstone (Runkel, Tipping, Alexander, and others, 2003). Solutionenhanced cavities along bedding planes and fractures are pronounced in the Shakopee Formation and along its contact with the Oneota Dolomite (Runkel, Tipping, Alexander, and others, 2003). Where karst features are present, the Prairie $\mathrm{du}$ Chien-Jordan aquifer is sensitive to contamination (Minnesota Pollution Control Agency, 1999). The farthest northern extent of the Prairie du Chien Group is in northern Washington County and southern Anoka County (fig. 1).

The Prairie du Chien Group is the uppermost bedrock unit under the deeper parts of White Bear Lake where a buried bedrock valley exists (figs. 1 and 4). This bedrock valley trends below the lake from the northwest near Ramsey County Beach to the southeast part of the lake. The depth of the bedrock below the lake ranges from less than $30 \mathrm{ft}$ on the southwest shore to greater than $200 \mathrm{ft}$ on the northeast shore (Minnesota Department of Natural Resources, 1998).

The St. Peter Sandstone of Middle Ordovician age unconformably overlies the Prairie du Chien Group (fig. 1; table 1). The St. Peter Sandstone is discontinuous within the study area and under much of White Bear Lake (fig. 4). The upper one-half to two-thirds of the formation consists of fine- and medium-grained, quartz sandstone that is massive to thick bedded; the lower part of the formation consists of multicolored mudstones, siltstones, and shales interbedded with very coarse sandstone (Meyer and Swanson, 1992; Swanson and Meyer,
1990). The St. Peter Sandstone, which contains the St. Peter aquifer, is an important source of water for southeastern Minnesota and can be hydraulically connected to the underlying Prairie du Chien-Jordan aquifer, functioning as a single aquifer (Minnesota Pollution Control Agency, 1999; Delin, 1991). However, water levels in the St. Peter aquifer and the Prairie du Chien-Jordan aquifer in the TMCA indicate that the St. Peter aquifer is hydraulically separated from the underlying Prairie du Chien-Jordan aquifer in the TCMA (Runkel, Tipping, Alexander, and others, 2003). No known geologic logs or geophysical data have been collected to determine the presence or absence of the St. Peter aquifer below White Bear Lake.

The Glenwood Formation, Platteville Formation, and Decorah Shale of Middle Ordovician age overlie the St. Peter Sandstone as the uppermost bedrock units of bedrock highs in the White Bear Lake area (fig. 1; table 1). The three units generally are less than $50 \mathrm{ft}$ thick in the White Bear Lake area and are not used for sources of water. The Glenwood Formation consists of thin, green, sandy shales ranging from 3 to $6 \mathrm{ft}$ thick, and the overlying Platteville Formation consists of fine-grained dolostone and limestone approximately $25 \mathrm{ft}$ thick (Meyer and Swanson, 1992; Swanson and Meyer, 1990). The Decorah Shale overlies the Platteville Formation as thin caps in the southern parts of the study area and consists of green, calcareous shale interbedded with thin limestone (Meyer and Swanson, 1992; Swanson and Meyer, 1990).

Quaternary-age glacial material overlies Ordovicianage bedrock throughout the White Bear Lake area (figs. 1 and 4; table 1) (Meyer and Swanson, 1992; Swanson and Meyer, 1990). The surficial geology in the area consists of glacial sandy lake sediments, outwash, and tills associated with the Grantsburg sublobe of the late-Wisconsin age Des Moines lobe and glacial tills and outwash associated with the St. Croix end moraine deposited by Wisconsin-age Superior lobe (Meyer and Swanson, 1992; Swanson and Meyer, 1990). Grantsburg glacial material overlies the Superior lobe material on the eastern, southwestern, and northern parts of the lakeshore, and Superior lobe material overlies pre- to late-Wisconsin Keewatin glacial till on the southeastern and eastern part of the lakeshore (Meyer and Swanson, 1992; Swanson and Meyer, 1990). Grantsburg sublobe outwash underlying the western part of the lake is the edge of the southern extent of the Anoka Sand Plain. Organic materials associated with wetlands commonly are on the land surface.

\section{Previous Investigations}

Previous hydrologic and hydrogeologic investigations have assessed low lake levels in White Bear Lake. Coates (1924) evaluated the hydrology of lakes, including White Bear Lake, in Ramsey County, Minnesota; the effects of low water levels in the lakes in the 1920s on development and recreational use; and potential changes to the lakes to increase water levels. Coates' (1924) estimated annual seepage from White Bear Lake in 1924 ranged from 5.7 to $7.2 \mathrm{in.}$ 
Setterholm (1991) completed a hydrologic assessment of factors, including groundwater withdrawals, controlling lake levels on White Bear Lake for the White Bear Lake Conservation District. In the study, Setterholm recognized that glacial deposits surrounding the lake have the highest static water levels and successive bedrock aquifers below the deposits and the lake have lower water levels, with water from the glacial deposits recharging the underlying Prairie du Chien-Jordan aquifer in the White Bear Lake area. The MDNR conducted a lake/groundwater interaction study of White Bear Lake following a period of low lake-water levels associated with a drought during 1988 and 1989 (Minnesota Department of Natural Resources, 1998). Results from this study indicated net annual groundwater exchange with White Bear Lake between 1981 and 1990 ranged from an 11.4-in. loss to local aquifers to a 4.4-in. gain to the lake; the average exchange was a 5-in. loss to local aquifers (Minnesota Department of Natural Resources, 1998). Groundwater-flow modeling for the 1998 study of the White Bear Lake area indicated increased groundwater withdrawals from high-capacity municipal wells decreased groundwater levels. Barr Engineering (2010) completed a potential vulnerability analysis of the TCMA surfacewater features, including White Bear Lake, for the Metropolitan Council. Results from the analysis classified White Bear Lake as a flow-through lake connected to groundwater and potentially vulnerable to groundwater withdrawals. The lake was classified as having a wide and shallow littoral zone, increasing the potential effects of groundwater withdrawals on lake-level changes.

Lake levels, water balance, and groundwater/surfacewater interactions have been studied in lakes in the northeastern part of the TCMA. Winter and Pfannkuch (1976) characterized the hydrologic interconnections between lakes and lateral groundwater flow within shallow deposits of the Anoka Sand Plain and patterns of groundwater flow between surficial, valley fill, and bedrock aquifers in a buried valley near Lino Lakes, Minnesota. Brown (1985) investigated hydrologic factors affecting lake-level fluctuations in Big Marine Lake in Washington County, Minnesota, defining interactions between the lake and local groundwater systems. Hydrogeologic and geochemical data collected in this study indicated lake-level fluctuations in the closed-basin lake were controlled primarily by groundwater discharge to and seepage from the lake, and changes in the potentiometric surface of the bedrock aquifer had minor effects on lake-level changes. Brown (1986) estimated the groundwater contribution in hydrologic and phosphorus budgets for seven lakes in the TCMA, including Square Lake, Eagle Point Lake, and Lake Elmo in Washington County, east of the study area. Seasonal hydrologic budgets to Square Lake and Lake Elmo indicated a net groundwater inflow to the lakes during all seasons of the year; net annual groundwater inflows were approximately 39 and 69 million cubic feet, respectively. Ruhl (1994) investigated groundwater/lake interactions for Vadnais Lake in northern Ramsey County and determined that groundwater inflow and lake-water discharge to aquifers represented a small percentage of the total water budget for the lake. Alexander and others (2001) assessed groundwater flows to Big Marine Lake (fig. 1), Big Carnelian Lake, Square Lake, and Little Carnelian Lake in the Carnelian-Marine Watershed District, Washington County. Big Carnelian Lake, Square Lake, and Little Carnelian Lake are east of the study area. They determined groundwater contribution to Big Marine Lake and Big Carnelian Lake was very small; most water entering the lakes came from precipitation. Groundwater inflow, however, was a major contributor to Square Lake and, to a lesser extent, Little Carnelian Lake. St. Croix Watershed Management Organization (2002) monitored groundwater inflow to Square Lake using seepage meters and determined that 70 percent of the water inflow to the lake was coming from local shallow groundwater, whereas only 9 percent of the water leaving the lake discharges to aquifers. The Minnesota Pollution Control Agency (2008) assessed the movement of trichloroethylene and cis-1,2-dichloroethylene in shallow groundwater flowing into Long Lake in New Brighton, Minnesota, west of the study area.

Several studies have documented changes in groundwater levels and flow in the Prairie du Chien-Jordan and other bedrock aquifers underlying the TCMA. Reeder (1966) compiled maps documenting changes in groundwater levels and flow for the Prairie du Chien-Jordan aquifer for selected periods from 1885 to 1965 . Norvitch and others (1973) delineated potentiometric surfaces for the winter of 1970-71, groundwater-level changes from December 1970 to August 1971, and long-term groundwater-level changes from winter 1965 to winter 1970 for the Prairie du Chien-Jordan aquifer to assess natural flow conditions and the effects of groundwater withdrawals on the aquifer. Larson-Higdem and others (1975) described vertical groundwater leakage rates from overlying aquifers to the Prairie du Chien-Jordan aquifer in the TCMA using potentiometric surfaces developed by Norvitch and others (1973). Their estimate of vertical leakage accounts for 10-20 percent of the increases in summer groundwater withdrawals in 1971 in the TCMA. Schoenberg (1984) and Guswa and others (1982) described groundwater flow for 1971-80 and changes in groundwater levels for the 1980s in the Prairie du Chien-Jordan aquifer. Delin and Woodward (1984) delineated a potentiometric surface for the Prairie du Chien-Jordan aquifer for southeastern Minnesota, including the Twin Cities basin. Horn (1983) investigated annual and seasonal groundwater withdrawal rates from the Prairie du Chien-Jordan aquifer between 1880 and 1980 in the TCMA. Schoenberg (1990) assessed the effect of groundwater withdrawal rates on groundwater levels in the TCMA in the 1970s. Andrews and others (1995) investigated groundwater-level declines and associated groundwater withdrawals from the Prairie du Chien-Jordan aquifer in the TCMA from 1980 to 1990. Sanocki and others (2009) determined potentiometric surfaces and groundwater-level changes in the Prairie du Chien-Jordan, the Franconia-Ironton-Galesville, and the Mount Simon-Hinckley aquifers in the TCMA for March and August 2008. 


\section{Methods of Study}

Hydrologic and water-quality data were collected and analyzed to understand the interactions between White Bear Lake and groundwater in the glacial sediments, the St. Peter aquifer, and the Prairie du Chien-Jordan aquifer. Existing lake-level, precipitation, evaporation, groundwater-level, and groundwater-withdrawal data from 1980 to 2010 were examined to assess temporal changes in relations between the lake, precipitation, and groundwater. Static water levels were measured in wells and surface-water bodies in March, April, and August 2011 to determine regional potentiometric surfaces and groundwater-flow gradients in the glacial water-table and buried aquifers, St. Peter, and Prairie du Chien-Jordan in the northeast TCMA. A variety of physical properties and chemical constituents were measured in precipitation, surface water, pore water in lake sediments, and groundwater to characterize groundwater/surface-water interactions in White Bear Lake. Three water-quality methods were used to identify potential locations of groundwater inflow to the lake and lake-water discharge to the aquifers: (1) differences in surface-water quality were measured using an autonomous, underwater vehicle (AUV) with a water-quality probe, (2) temperatures were measured in littoral-zone sediments, and (3) pore-water samples were collected for analysis of major constituents and stable isotopes. At these locations, hydraulic-head differences between White Bear Lake and lake sediments and seepage rates across the sediment-lake-water interface were measured to determine the amount of groundwater/lake-water exchange. A lake-sediment core was collected at the deepest part of White Bear Lake, and penetration-probe measurements were made to estimate the thickness of organic sediments that may restrict the amount of water flow between the lake and the underlying aquifers.

\section{Historical Hydrologic Data}

Historical hydrologic data from the White Bear Lake area, including lake levels, groundwater levels, precipitation, evaporation, and groundwater withdrawals, were compiled and examined to assess trends that might be associated with water-level changes in White Bear Lake. Annual data were evaluated by calendar year. Seasonal comparisons for each year were based on the following seasons: (1) winter (January, February, and December); (2) spring (March, April, and May); (3) summer (June, July, and August); and (4) fall (September, October, and November).

Water-level measurements for White Bear Lake between 1924 and 2011 and groundwater-level data for observation wells within the study area between 1980 and 2011 were acquired from the MDNR (Minnesota Department of Natural Resources, 2011d, 2012). The observation wells were completed in glacial water-table or buried aquifers or in the Prairie du Chien-Jordan aquifer (Minnesota Department of Natural Resources, 2011d). Historical water-level measurements for
White Bear Lake were in reference to the Ramsey County 1912 datum, and historical groundwater levels were in reference to the NAVD 88. Measurements in reference to the Ramsey County 1912 datum were converted to NAVD 88 by adding $0.46 \mathrm{ft}$ (Minnesota Department of Natural Resources, 2012).

Daily precipitation data $(P)$ from 1924 through 2011 were compiled from the Minnesota high-density volunteer observation network and the National Weather Service network (Minnesota Climatology Working Group, 2011a). Daily precipitation data for 1958 through 2011 were selected from the high-density observation site closest to the approximate geographic center of White Bear Lake (45.07703 decimal degrees latitude, 92.98331 decimal degrees longitude) with no more than three missing daily observations per month (Minnesota Climatology Working Group, 2011a). High-density network data were not available before 1958 and were missing for brief periods from 1958 through 2011 (Minnesota Climatology Working Group, 2011a). Data from the closest National Weather Service station were used for these data gaps (Minnesota Climatology Working Group, 2011a). The compiled precipitation data were compared to the precipitation record from a "single, long-term" observation site approximately 4 miles (mi) southwest of White Bear Lake (Peter Boulay, Minnesota Department of Natural Resources, written commun., January 13, 2012) and a "wetland delineation precipitation data retrieval from a gridded database" determined by the Minnesota Climatology Working Group (Minnesota Climatology Working Group, 2012a) to identify any periods of systematic "observer bias." Annual precipitation was calculated by summing all precipitation within a calendar year. Cumulative departure from normal precipitation was determined on an annual basis with the high-density network data from 1971 through 2011. Seasonal precipitation was determined by summing all precipitation events within a given season, as previously defined, each year.

Monthly evaporation totals $(E)$ for April through October during 1972 through 2011 were compiled from the nearest class A evaporation-pan monitoring site approximately 12 mi southwest of White Bear Lake (Minnesota Climatology Working Group, 2011b). Evaporation from the surface of White Bear Lake was estimated by multiplying the monthly evaporation-pan totals by a coefficient of 0.75 . This coefficient is the mid-point in the typical range ( 0.65 to 0.85 ) of class A evaporation-pan coefficients (American Society of Civil Engineers, 1996). Pan evaporation usually peaks several months before peak evaporation from deep lakes because of differing thermal characteristics between the pan and the lakes. Using values of pan evaporation may distort the seasonal distribution of estimates of lake-surface evaporation (American Society of Civil Engineers, 1996). To avoid this seasonal distortion, most of the analyses performed in this report used annual evaporation totals.

Groundwater-withdrawal data from 1980 through 2010 were acquired from the MDNR Water Appropriations Permit Program (Minnesota Department of Natural 
Resources, 2011b). All water users withdrawing more than 10,000 gallons (gal) of water per day or 1 million gallons per year (Mgal/yr) are required by the State of Minnesota to obtain a water-use (appropriation) permit and report monthly wateruse amounts to the MDNR (Minnesota Department of Natural Resources, 2011b). Only annual groundwater withdrawals were available for each permit from 1980 through 1987; monthly groundwater withdrawals were available for each permit from 1988 through 2010. Groundwater withdrawal data were summarized by aquifer, use, and season. No distinction was made between wells extracting water from glacial watertable aquifers and buried aquifers; all withdrawals were classified as being from glacial aquifers. Wells open to the Prairie $\mathrm{du}$ Chien Group, the Jordan Sandstone, or both were classified as completed in the Prairie du Chien-Jordan aquifer. In this study, wells withdrawing water from multiple aquifers or bedrock aquifers deeper than the Prairie du Chien-Jordan aquifer were classified as multiple-aquifer wells. Water use for the permitted wells was categorized into two groups: municipal and other. Water withdrawn for the municipalities of Centerville, Columbus, Forest Lake, Hugo, Lino Lakes, Mahtomedi, North St. Paul, Vadnais Heights, White Bear Lake, and White Bear Township were included in the municipal category. All other permitted withdrawals in the study area were classified as "other" uses, including water used for industrial processing, construction dewatering, and irrigation of golf courses. Total seasonal groundwater withdrawals were calculated according to the seasons previously defined from 1988 through 2010 .

Annual per capita groundwater withdrawals were determined for 1980, 1990, 2000, and 2010 by dividing the average groundwater withdrawal for the 3 years of available data closest to the decadal census by the population at each census. For the per capita withdrawal estimate of 1980, withdrawals during 1980-82 were averaged; for 1990, withdrawals during 1989-91 were averaged; for 2000, withdrawals during 1999-2001 were averaged; and for 2010, withdrawals during 2008-10 were averaged. Seasonal per capita groundwater withdrawals were determined for the census years of 1990 , 2000 , and 2011 by dividing the seasonal average groundwater withdrawal for the 3 years of available data closest to the decadal census by the population at each census.

Daily lake levels of White Bear Lake were estimated for 1978 through 2011 by linear interpolation between successive lake-level observations. A relation between lake elevation and volume and a relation between lake elevation and area for White Bear Lake developed by the Minnesota Department of Natural Resources (1998) were used to convert interpolated daily lake levels into daily lake volumes and daily lake areas, respectively. Annual changes in lake level and lake volume $(\triangle L W)$ were calculated for each year between 1978 and 2011 by subtracting the lake level or volume on January 1 of a calendar year from the corresponding value on December 31 of the same calendar year. Seasonal changes in lake level and lake volume were calculated by summing the daily changes of each value within each season of each year from 1978 through 2011.
Daily surface-outflow volumes $(\mathrm{SO})$ from the lake through the outflow structures near Ramsey County Beach were calculated. Lake levels were converted to outflow volume on a daily basis with a surface-outflow rating curve, developed by the MDNR, for the structures near Ramsey County Beach (Minnesota Department of Natural Resources, 1998). Zero outflow was assumed whenever the lake level was below $924.3 \mathrm{ft}$ above Ramsey County 1912 datum. Surface outflows also were expressed in terms of feet of lake level lost by dividing the outflow volume by the lake area on a daily basis. Daily surface-outflow values were then summed on an annual or a seasonal basis for further analysis.

Precipitation $(P)$ on the lake surface was converted to volume on a daily basis by multiplying the precipitation depth by the lake area. Evaporation from the lake surface $(E)$ was converted to volume on a monthly basis by multiplying the evaporation depth by the monthly average lake area. These volumes were then summed on an annual or a seasonal basis for further analysis.

\section{Regression Analyses}

A series of regression analyses were done to determine the significance of different components of the water balance in explaining changes in the water level and volume of White Bear Lake. These analyses were done for years after 1977 to avoid years when the lake level was augmented with groundwater from underlying aquifers (Minnesota Department of Natural Resources, 1998). The water balance of White Bear Lake is described by the following equation:

$$
\Delta L W=P+S R-E-S O+G W_{e x},
$$

where

$$
\begin{aligned}
& \Delta L W \text { is the change in lake level or volume, } \\
& P \text { is the total precipitation falling on lake surface, } \\
& S R \text { is the surface runoff into the lake, } \\
& E \text { is the evaporation from the lake surface, } \\
& S O \text { is the surface-water outflow through structures } \\
& \text { near Ramsey County Beach, and } \\
& G W_{e x} \text { is the net groundwater exchange, including all } \\
& \text { inputs to and losses from White Bear Lake. }
\end{aligned}
$$

Because White Bear Lake is a closed-basin lake, its level has likely responded to local precipitation. The relation of the annual change in the water level (or volume) of White Bear Lake to annual precipitation was examined with the following equation:

$$
\Delta L W_{i}=b_{0}+\left(b_{1} \times P_{i}\right)+\varepsilon_{i},
$$

where

$$
\begin{aligned}
& \Delta L W_{i} \quad \text { is the change in White Bear Lake level, in } \\
& \text { feet, or volume, in millions of gallons; } \\
& b_{0} \quad \text { is the intercept, in units of lake change (feet or } \\
& \text { millions of gallons); }
\end{aligned}
$$


$b_{1} \quad$ is the slope coefficient for the precipitation explanatory variable, in units of lake change (feet or millions of gallons) per inch of precipitation;

$P_{i} \quad$ is the observed cumulative precipitation depth on lake surface, in inches; and

$\varepsilon_{i} \quad$ is the random error (residual) for observation $i$, in units of lake change (feet or millions of gallons).

Analysis of covariance (ANCOVA) (Helsel and Hirsch, 2002) was used to test the hypothesis that the relation between the change in water level (and volume) of White Bear Lake and precipitation is significantly different between two periods: (0) 1978-2002, and (1) 2003-11. The two periods were identified through examination of the water-level data for White Bear Lake. The most recent major lake-level decline began in 2003 and continued through 2011. The goal of the ANCOVA was to compare the relation between lake-level change and precipitation during the recent decline (2003-11) with an earlier period. ANCOVA models were constructed with precipitation $(P)$ and time period $(T p)$ as explanatory variables for annual and seasonal changes in lake level and lake volume:

$$
\Delta L W_{i}=b_{0}+\left(b_{1} \times P_{i}\right)+\left(b_{2} \times T_{p}\right)+\varepsilon_{i},
$$

where

$$
\begin{aligned}
& \Delta L W_{i} \quad \text { is the change in lake level or lake volume, in } \\
& \text { feet or millions of gallons; } \\
& b_{0} \quad \text { is the intercept, in units of lake change (feet or } \\
& \text { millions of gallons); } \\
& b_{1} \quad \text { is the slope coefficient for the precipitation } \\
& \text { explanatory variable, in units of lake } \\
& \text { change (feet or millions of gallons) per } \\
& \text { inch of precipitation; } \\
& P_{i} \quad \text { is the observed cumulative precipitation depth } \\
& \text { on lake surface, in inches; } \\
& b_{2} \quad \text { is the slope coefficient for the time-period } \\
& \text { explanatory variable, in units of lake } \\
& \text { change (feet or millions of gallons); } \\
& T_{p} \quad \text { is the time-period binary variable, either } 0 \\
& \text { (for 1978-2002) or } 1 \text { (for 2003-11) for } \\
& \text { observation } i \text {, dimensionless; and } \\
& \varepsilon_{i} \quad \text { is the random error (residual) for observation } \\
& i \text {, in units of lake change (feet or millions } \\
& \text { of gallons). }
\end{aligned}
$$

ANCOVA models allow for the incorporation of qualita-

tive factors, defined by binary, or dummy, variables, and blend regression and analysis of variance (Helsel and Hirsch, 2002). The ANCOVA models in this report do not provide a mechanistic explanation for any differences between periods. The binary variables assigned to the two periods are 0 and 1 for 1978-2002 and 2003-11, respectively. In all ANCOVA models in this report that utilize the time-period binary variable $\left(T_{p}\right)$, the $b_{2}$ coefficient (eqs. 3 and 4) represents the shift or difference between the two periods. For 1978-2002, the time-period binary variable is 0 , and equation 3 , for example, simplifies to $\Delta L W_{i}=b_{0}+\left(b_{1} \times P_{i}\right)+\varepsilon_{i}$. For 2003-11, the binary variable is 1 , and equation 3 simplifies to $\Delta L W_{i}=\left(b_{0}+b_{2}\right)+\left(b_{1} \times P_{i}\right)+\varepsilon_{i}$.

Additional ANCOVA models were constructed and included estimates of lake-surface evaporation and surfacewater outflow through the outflow structures near Ramsey County Beach:

$$
\left(\Delta L W_{i}+S O_{i}\right)=b_{0}+\left[b_{1} \times\left(P_{i}-E_{i}\right)\right]+\left(b_{2} \times T_{p}\right)+\varepsilon_{i},
$$

where

$$
\begin{array}{cc}
\Delta L W_{i} & \text { is the change in White Bear Lake volume or } \\
& \text { level, in feet or millions of gallons; } \\
S O_{i} & \text { is the cumulative surface-water outflow, in } \\
& \text { feet of lake level or millions of gallons; } \\
b_{0} & \text { is the intercept, in units of lake change plus } \\
& \text { surface outflow (feet or millions of gallons); } \\
b_{1} & \text { is the slope coefficient for the precipitation } \\
& \text { minus evaporation explanatory variable, in } \\
& \text { units of lake change plus surface outflow } \\
& \text { (feet or millions of gallons) per inch of } \\
& \text { precipitation minus evaporation; } \\
P_{i} & \text { is the observed cumulative precipitation depth } \\
& \text { on lake surface, in inches; } \\
E_{i} & \text { is the cumulative depth of pan-estimated } \\
& \text { evaporation from the lake surface, in inches; } \\
b_{2} & \text { is the slope coefficient for the time-period } \\
& \text { explanatory variable, in units of lake } \\
& \text { change plus surface-water outflow (feet or } \\
& \text { millions of gallons); } \\
T_{p} & \text { is the time-period binary variable, either } 0 \\
& \text { (for 1978-2002) or 1 (for 2003-11) for } \\
& \text { observation } i, \text { dimensionless; and } \\
\varepsilon_{i} & \text { is the random error (residual) for observation } \\
& i, \text { in units of lake change plus surface } \\
& \text { outflow (feet or millions of gallons). }
\end{array}
$$

The $\left(\Delta L W_{i}+S O_{i}\right)$ term accounts for the observed change in lake level or volume $\left(\Delta L W_{i}\right)$ and the change in lake level or volume that would have been observed had the outflow structures not been in place. The $\left(P_{i}-E_{i}\right)$ term adjusts total annual direct precipitation input to the lake surface by the amount of lake-surface evaporation.

Multiple linear regression was used to identify possible explanations for annual changes in lake level and volume for 1980 through 2010. Multiple linear regression models were of the following form (the subscript, $i$, has been omitted to simplify the notation):

$$
\Delta L W=b_{0}+b_{1} x_{1}+\mathrm{b}_{2} x_{2}+\ldots+\mathrm{b}_{k} x_{k}+\varepsilon,
$$

where

$$
\begin{aligned}
\Delta L W & \text { is the change in White Bear Lake volume or level, } \\
b_{0} & \text { is the intercept, } \\
b_{1}, b_{2}, \ldots, b_{k} & \text { is the slope coefficients for explanatory } \\
& \text { variables } x_{1}, x_{2}, \ldots, x_{k}, \text { and } \\
\varepsilon & \text { is the random error in the data. }
\end{aligned}
$$


Candidate explanatory variables of precipitation $(P)$, evaporation $(E)$, surface-water outflow $(S O)$, and annual groundwater withdrawals from the Prairie du Chien-Jordan aquifer $\left(W_{P D C J}\right)$ were used in multiple linear regression models to explain annual changes in lake level and volume. Candidate explanatory variables of precipitation and time (year) were used in multiple linear regression models to explain annual and seasonal trends in groundwater withdrawals from the Prairie du Chien-Jordan aquifer. The adjusted R-squared value, Mallow's Cp statistic, and the prediction error sum of squares of each model and the significance of explanatory variable coefficients at an alpha of 0.05 were the criteria used to identify the most reasonable regression model for a given response variable (Helsel and Hirsch, 2002). After a reasonable regression model that explained the annual lake-volume changes was identified, sequential sum of squares was used to determine if the continuous explanatory variables in the multiple regression model explained any significant difference between the two periods of the ANCOVA model that was used to explain annual lake-volume changes (Helsel and Hirsch, 2002).

\section{Groundwater-Level Synoptic Studies}

Regional hydraulic gradients of the glacial aquifers (water-table and buried), St. Peter aquifer, and Prairie du Chien-Jordan aquifer were determined through groundwaterlevel synoptic studies during two seasons, spring and summer, in 2011 across a network of wells and surface-water bodies. A groundwater-level synoptic study involves the measurement of groundwater levels in many wells over a short time period to provide a "snapshot" of hydraulic gradients in one or more aquifers. In this study, the spring synoptic waterlevel study was between March 21 and April 7, 2011, and the summer synoptic water-level study was between August 9 and August 23, 2011. In the TCMA, groundwater use typically is low in the spring months of March and April and high during the summer months of June, July, and August (Metropolitan Council, 2004). Water levels in these two synoptic studies were compared to see if groundwater levels and hydraulic gradients changed between the different groundwater-use periods.

Groundwater levels for 224 municipal, domestic, and observation wells and surface-water levels from 66 lakes in the northeast TCMA were measured in the spring (March/ April 2011) synoptic study (fig. 5; table 2). The summer synoptic study (August 2011) consisted of measurements for 230 wells and 68 surface-water levels. The selection of wells for the synoptic studies was based on the availability of construction and geologic information for the well, the aquifer from which the well obtained water, the location of the well relative to other wells in the study, and the approval of the well owner to measure water levels. Construction and geologic data for the wells were obtained from the Minnesota County Well Index (CWI) (Minnesota Department of Health/ Minnesota Geological Survey, 2011). All wells listed in CWI that were (1) open to the glacial aquifers, St. Peter aquifer, or
Prairie du Chien-Jordan aquifer, and (2) within the approximate White Bear Lake groundwater watershed area were identified as potential wells for the synoptic studies. The selected wells measured in the study were accessible, only open to one aquifer, and distributed as evenly as possible throughout the study area. The study area was defined by an approximate groundwater watershed for White Bear Lake delineated by MDNR (Minnesota Department of Natural Resources, 1998).

The selected wells were located in the field, and their latitude/longitude coordinates were acquired using a realtime, kinematic global positioning system (RTK-GPS). Land-surface elevation at each well was determined using the RTK-GPS. A real-time correction of the latitude/longitude coordinates and elevations was made using the Minnesota Department of Transportation (MnDOT) Continuously Operating Reference Station (CORS) Network (Minnesota Department of Transportation, 2012). All locations were determined in reference to the North American Datum of 1983 (NAD 83), and elevations were determined in reference to the NAVD 88. Elevations and latitude/longitude coordinates could not be determined for five wells because of poor satellite coverage at the well locations. Light detection and ranging (LiDAR) data obtained from the Rice Creek Watershed District (Rice Creek Watershed District, 2011) were used to estimate the landsurface elevations at these five wells. The MDNR supplied the land-surface elevations for the MDNR observation wells (Minnesota Department of Natural Resources, 2011d).

Groundwater levels were measured using a steel or electrical tape to the nearest $0.01 \mathrm{ft}$. Measurements were made when the wells were not pumping. Groundwater levels were measured in the high-capacity wells after the well pumps had been shut off for at least 2 hours, assuming the water levels would have time to recover before measuring. For each well, the height of an established measuring point (top of well casing) above the land surface was subtracted from the water-level measurement to obtain the depth to water below land surface. The depth to water was then subtracted from the land-surface elevation to obtain the groundwater elevation (hydraulic head).

Lake levels were measured on 68 lakes within the study area; most of the lakes were part of the MDNR lake-level monitoring program (Minnesota Department of Natural Resources, 2012). Lakes in this program have a staff gage that is periodically measured. Water levels were measured in the lakes in both synoptic studies using RTK-GPS to the nearest $0.05 \mathrm{ft}$; corrections were provided through the MnDOT CORS Network (Minnesota Department of Transportation, 2012).

Potentiometric surfaces and seasonal water-level change maps were constructed using the groundwater-level and lake-level elevations measured in March/April 2011 and August 2011 for four aquifers: two glacial aquifers (watertable and buried), St. Peter aquifer, and Prairie du ChienJordan aquifer. Potentiometric surfaces show the elevation at which water would have stood in a tightly cased well open to the respective aquifer and are used to better understand groundwater flow. 


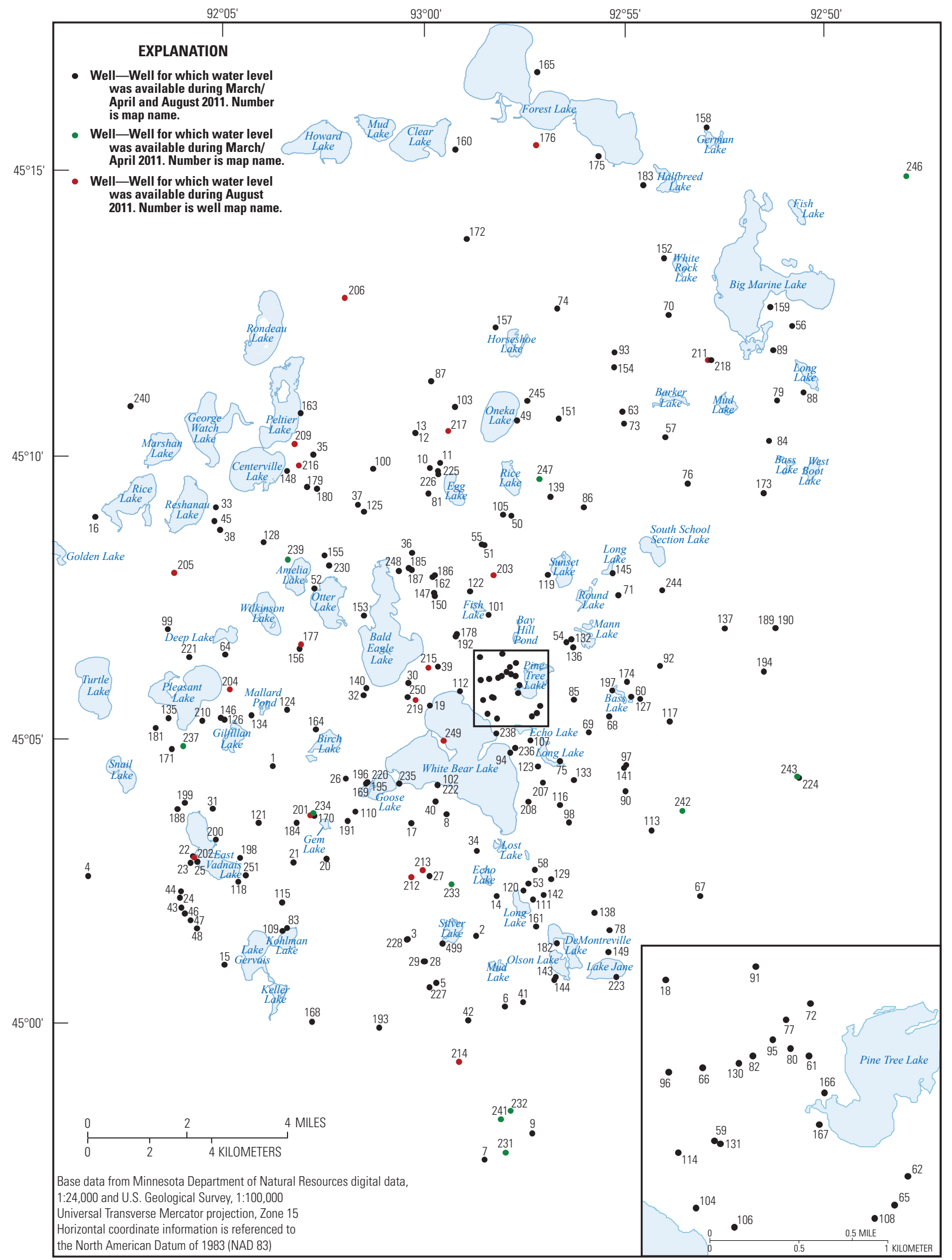

Figure 5. Locations of wells and lakes where water levels were measured in March/April and August 2011, northeast Twin Cities Metropolitan Area, Minnesota. 
Table 2. Number of wells and lakes where water levels were measured in synoptic studies in the White Bear Lake area in March/April and August 2011, northeast Twin Cities Metropolitan Area, Minnesota.

\begin{tabular}{lcc}
\hline \multicolumn{1}{c}{ Aquifer/water body } & $\begin{array}{c}\text { March/April } \\
\mathbf{2 0 1 1}\end{array}$ & $\begin{array}{c}\text { August } \\
\mathbf{2 0 1 1}\end{array}$ \\
\hline Glacial aquifer (water table) & 13 & 13 \\
Glacial aquifer (buried) & 46 & 51 \\
St. Peter aquifer & 50 & 49 \\
Prairie du Chien Group-Jordan aquifer & 115 & 117 \\
Lakes & 66 & 68 \\
\hline
\end{tabular}

\section{Water-Quality Data}

Various water-quality data were collected in 2011 to assess groundwater and surface-water interactions at White Bear Lake. An AUV equipped with water-quality probes was used to determine the spatial distributions of basic waterquality characteristics in White Bear Lake. Surface-water and lake-sediment temperatures were measured along the lakeshore; small and large differences between the two temperature measurements indicated potential locations for surfacewater outflow to local groundwater systems and groundwater inflow to lakes. Several physical and chemical water-quality constituents were measured in precipitation, surface-water, lake-sediment pore-water, and groundwater samples to characterize these different water sources and identify potential connections between the sources.

\section{Autonomous, Underwater Vehicle Survey}

Water quality of White Bear Lake was surveyed July 11 through July 14, 2011, using an AUV equipped with waterquality probes. The Ecomapper ${ }^{\mathrm{TM}} \mathrm{AUV}$ generates a large quantity of water-quality data that can be used to generate high-resolution maps of water-quality characteristics and bathymetry throughout a surface-water body. Seven waterquality sensors, an echo sounder, and a side-scan sonar on the AUV were used to continuously measure water depth, water temperature, specific conductance, dissolved oxygen, $\mathrm{pH}$, turbidity, total chlorophyll concentration, and blue-green algae concentration. The water-quality sensors on the AUV were calibrated following procedures outlined in the USGS National Field Manual for the Collection of Water-Quality Data (U.S. Geological Survey, variously dated) and outlined by the manufacturer of the probes. All sensors were calibrated before deployment, and calibrations were checked for drift following the survey. When possible, all calibrations were completed in the controlled environment of a laboratory. A differentially corrected global positioning system (GPS) was used to guide the AUV through the lake along pre-programmed survey lines called missions.

A series of seven missions were completed with the AUV in the north, central, and southeast parts of the lake (table 3). The survey was completed in the summer when temperature differences between lake water and local groundwater were high and offered an opportunity to identify locations of possible groundwater inflow. During each mission, water temperature, specific conductance, dissolved oxygen, $\mathrm{pH}$, turbidity,

Table 3. Summary of autonomous, underwater vehicle (AUV) survey missions completed on White Bear Lake, northeast Twin Cities Metropolitan Area, Minnesota, July 11-14, 2011.

[CDT, Central daylight-savings time]

\begin{tabular}{|c|c|c|c|c|c|c|}
\hline $\begin{array}{l}\text { Mission } \\
\text { number }\end{array}$ & Date & $\begin{array}{l}\text { Start time } \\
\text { (CDT) }\end{array}$ & $\begin{array}{l}\text { End time } \\
\text { (CDT) }\end{array}$ & Location & Survey technique & Comments \\
\hline 1 & July 11,2011 & $11: 07$ & $12: 19$ & North bay of south lobe & Constant depth, surface & $\begin{array}{l}\text { Reconnaissance survey along } \\
\text { shoreline. }\end{array}$ \\
\hline 3 & July 13, 2011 & $8: 28$ & $10: 20$ & North bay of south lobe & $\begin{array}{l}\text { Constant height above } \\
\text { bottom }\end{array}$ & Sweep pattern through bay. \\
\hline 5 & July 14, 2011 & $8: 14$ & $10: 00$ & $\begin{array}{l}\text { Middle of the lake } \\
\text { between lobes }\end{array}$ & $\begin{array}{l}\text { Undulate surface to } \\
\text { near bed }\end{array}$ & $\begin{array}{l}\text { Sensor data failed to } \log \text { on the } \\
\text { data logger. }\end{array}$ \\
\hline 6 & July 14, 2011 & $10: 15$ & $11: 17$ & $\begin{array}{l}\text { Deep line from south } \\
\text { lobe to north lobe }\end{array}$ & $\begin{array}{l}\text { Constant height above } \\
\text { bottom }\end{array}$ & Connects survey zones (lobes). \\
\hline
\end{tabular}


chlorophyll, and blue-green algae were measured once every second as the AUV moved along the survey lines. The AUV was run at water depths varying from 0 to $60 \mathrm{ft}$ below the water surface and completed a variety of survey methods, including constant depth, constant height above bottom, and undulation depth techniques.

One limitation to the use of the AUV to assess groundwater inflow to White Bear Lake was the ability of the vehicle to get close to the sediment-water interface in shallow waters where abundant milfoil was present. This aquatic vegetation covered large areas of the shallower parts of the lake, growing as much as $15 \mathrm{ft}$ above the lake bottom and emerging from the water surface at some locations. During the first 2 days of the survey, the AUV was run at the water surface in water depths shallower than $6 \mathrm{ft}$ and was allowed to dive to depths $6 \mathrm{ft}$ above the water-sediment interface when water depths were deep enough to prevent milfoil growth. During a mission on the second day of the survey, the AUV was snagged by milfoil while it was maintaining a height of $6 \mathrm{ft}$ above the lake bottom. To avoid being snagged by milfoil in subsequent missions, the AUV was operated at the water surface in water depths shallower than $20 \mathrm{ft}$. At water depths greater than $20 \mathrm{ft}$, the AUV was programmed to maintain a height of $15 \mathrm{ft}$ above the lake bottom to ensure the AUV stayed above the milfoil. Milfoil growth was not observed during this survey in areas of the lake having water depths greater than $20 \mathrm{ft}$. At water depths greater than $20 \mathrm{ft}$, this mid-survey programming change allowed the vehicle to travel closer to the sedimentwater interface where groundwater interaction might take place.

Some of the AUV water-quality data required omission and careful interpretation because of inherently noisy sensors and sensor malfunction. Data collected by the chlorophyll and blue-green algae sensors are inherently noisy, particularly in turbid waters (Gons, 1999); therefore, the data were interpreted with caution. Both sensors were calibrated with a one-point calibration in deionized water (zero); therefore, values were not absolute concentrations but were relative to the calibration value. Turbidity data collected after July 12 were omitted because the sensor malfunctioned.

A series of post-processing steps were followed to correct the water-quality and depth data before data analysis. Post-processing corrections were made for AUV drift, depth adjustments for sensor offsets, and removal of outlying values from the data. AUV drift during dives generally was induced by compass errors and was identified by screening the vehicle track for jumps in position greater than $16.4 \mathrm{ft}$ $(5 \mathrm{~m})$ in 1 second. Jumps generally were recorded when the vehicle surfaced and corrected its computed position on the basis of GPS data in its track log. Any identified drift was corrected by applying a linear correction between the dive point and the surface point assuming a constant heading and speed. After applying the drift correction, a depth correction was applied to the total water-column depth to account for the offset of the vertical beam from the water surface. After applying the corrections, the time-series data were plotted and screened manually to identify outliers and remove them from the data. Once all outliers were removed, time-series data for turbidity, chlorophyll, and blue-green algae were filtered using an iterative process to minimize noise in the data. The filter was a simple, moving average applied to the data with a user-defined window size that would minimize the noise yet maintain the true oscillations of the data. Temporal corrections to each of the water-quality properties or constituents were applied as needed to account for lags in the response time of the sensor. Such corrections commonly are applied in oceanography (for example, Johnson and others, 2007) and are used to ensure that measurements are coincident on the same parcel of water for every sample when response times vary between sensors.

Anomalies were computed for each of the water-quality characteristics, and corrected data were used to generate water-quality data files compatible with geographic information systems (GIS) for analysis. Median vertical profiles were calculated for each water-quality characteristic during each of the AUV surveys. Non-diving surveys computed the median surface-water characteristics. The median vertical profiles were computed by dividing the extent of the verticalprofile data into discrete depth intervals and computing the median value for each depth interval. Anomalies were computed by taking the difference between an observed value at a specific point and the median value for that sample depth. The anomalies were used to identify any observed data that were inconsistent with the median value for that depth in the water body being surveyed. Not only does this effectively eliminate the depth-dependence of the data, but it also collapses the data by allowing display of all the data on a two-dimensional plan-view figure with no need to extract and visualize data for different depth planes. Using this technique, any potential groundwater inflows that produce uncharacteristic water-quality signatures at a specific depth will be highlighted as an anomaly because the difference between the inflow water-quality value and the water-quality value for the remainder of the lake were plotted at that specific depth. For missions where all data were collected at the surface, the computed anomalies were simply the difference between the observed value at a point and the median value for the entire data.

\section{Lake-Sediment Temperature Surveys}

In situ temperature was measured in lake sediments along the shores of White Bear, Bald Eagle, and Goose Lakes (figs. 1 and 3). In situ temperature measurements of lake sediment are indicative of pore-water and sediment temperatures. Lake-sediment temperature measurements have been used in similar studies to identify potential groundwater-inflow areas where water-quality samples could be collected and seepage rates measured to further confirm and quantify the inflow of groundwater (Jones, 2006). Lake-sediment temperatures were measured along the shorelines because groundwater inflow 
to lakes has been observed to decrease exponentially with distance from shore (Lee, 1977; Fellows and Brezonik, 1980; Erickson, 1981; Attanayake and Waller, 1988; Rosenberry, 1990). Other studies report the decrease in groundwater inflow with distance from a lakeshore is not exponential because of heterogeneity of the sediment (Woessner and Sullivan, 1984; Krabbenhoft and Anderson, 1986), but it was beyond the scope of this study to collect sediment temperature data for entire lakes.

A handheld temperature probe was used to measure the temperatures. The probe consisted of a thermocouple at the end of a pointed 6-ft stainless-steel hollow tube connected to a handheld, digital display. The thermocouple probe was calibrated before the collection of temperature data using a thermally regulated water bath and a registered thermometer.

Temperature was measured from July 20 through August 29, 2011, when the difference between lake-water and groundwater temperatures was thought to be the greatest. At areas of groundwater inflow to the lake, the sediment temperatures are cooler than surface-water temperatures. At areas with either discharge from the lake to aquifers or little to no groundwater inflow, sediment temperatures are similar to surface-water temperatures. Surface-water temperatures were measured in the middle of the water column at approximately half-hour intervals. Sediment temperatures were measured every 100 to $300 \mathrm{ft}$ along the shoreline. At each measurement location, the probe was pushed into the lake sediment by hand as deep as possible. The water-column depth to the sediment interface (lake-water depth), the depth of probe insertion into the sediment, and the GPS latitudelongitude coordinates were recorded at each location. Lakewater depths ranged from 0 to $2.0 \mathrm{ft}$ at each measurement location, and insertion depths into the sediment ranged from 0.5 to $4.5 \mathrm{ft}$, with most depths greater than $1.0 \mathrm{ft}$. At Shingobee Lake in northern Minnesota (Rosenberry and others, 2000) and in three lakes of northeastern Minnesota (Jones, 2006), areas of groundwater discharge could be mapped effectively by measuring temperature less than 1 in. beneath the lakebed along the shoreline. Temperature stabilization in the surface water and lake sediment took approximately 30 seconds at each location.

\section{Water-Quality Sample Collection, Handling, Analysis, and Quality Control}

Physical and chemical water-quality characteristics were measured in 7 precipitation, 28 surface-water, 15 lake-sediment pore-water, and 16 groundwater samples to characterize and identify potential connections between different sources of water to White Bear Lake. All precipitation, surfacewater, pore-water, and groundwater samples were collected in 2010-11 following USGS protocols outlined in the USGS National Field Manual for the Collection of Water-Quality Data (U.S. Geological Survey, variously dated).

\section{Sample Collection}

Bulk precipitation and snowpack samples were collected for analysis of oxygen-18/oxygen-16 ratios and deuterium/protium ratios to determine a meteoric water line for the White Bear Lake area to be used in the analysis of ratios for groundwater and lake-water samples. Bulk precipitation samples were collected at a precipitation station on the east shore of White Bear Lake (USGS station 450334092574201) (fig. 3). The samples were collected in 4-L amber glass jars through plastic funnels during precipitation events on July 14, August 31, and October 12, 2011. Total precipitation amounts recorded at the nearest high-density observation site during these events were $0.20,0.16$, and 0.55 in., respectively (Minnesota Climatology Working Group, 2011a). The amber glass bottles used to collect the precipitation samples were deployed within 24 hours of the start of anticipated precipitation and were collected within 24 hours following the end of precipitation. Each precipitation sample was immediately transferred from the collection jar to a $60-\mathrm{mL}$ clear glass bottle, which was then capped with a polyseal cap and wrapped in electrical tape. Snowpack samples were collected from four sites around White Bear Lake on March 14, 2011 (fig. 3). An open 2-in. diameter polycarbonate tube was pushed through the snowpack, and the collected snow was emptied into a 4-L plastic container. Several snow cores were composited at each site. Each plastic container was covered, and the snow sample in each container was melted for 24 hours at room temperature. After the sample had completely melted, the meltwater was transferred to a $60-\mathrm{mL}$ clear glass bottle that was then capped with a polyseal cap and wrapped in electrical tape.

Surface-water samples were collected from 11 lakes in the northeast TCMA to assess potential water-quality differences associated with water-level differences between the lakes. The lakes were Bald Eagle, Birch, Echo, Goose, Long, Lost, Mann, Pine Tree, Sunset, Turtle, and White Bear Lake (fig. 1). The surface-water samples were analyzed for physical properties, major constituents (anions and cations), oxygen-18/oxygen-16 ratios, and deuterium/protium ratios. The lakes were selected on the basis of their proximity to White Bear Lake, the availability of water-level data, or the occurrence of recently declining water levels. Samples were collected from the littoral zone of each lake, either by wading into the water or from an existing dock. Onsite waterquality measurements of surface water were made in situ by lowering a multiprobe meter into the middle two-thirds of the lake-water column. These measurements were specific conductance, $\mathrm{pH}$, water temperature, and dissolved oxygen concentration; barometric pressure also was recorded. A peristaltic pump was used to draw water near the center of the water column through a 0.19-in. inside-diameter C-Flex ${ }^{\circledR}$ tubing.

Samples of lake-sediment pore water were collected for analysis of physical properties, major constituents (cations and anions), oxygen-18/oxygen-16 ratio, and deuterium/ 
protium ratio to characterize groundwater and lake-water interactions and identify potential areas where groundwater flows into White Bear Lake. Pore-water sampling sites were selected to confirm groundwater inflow and lake-water discharge to aquifers at areas identified during the lake-sediment temperature survey. Onsite water-quality of pore water was measured using a multiprobe meter and a flow-through cell receiving water pumped from lake sediments. A peristaltic pump was used to draw water from lake sediments through 0.19-in. inside-diameter C-Flex ${ }^{\circledR}$ tubing connected to a minipiezometer screened in the lake sediments. Mini-piezometers or hydraulic potentiomanometers are portable drive probes that are used with manometers to measure head differences between pore waters in lake sediments and lake water and can be used to collect pore-water samples from lake sediments (Rosenberry and LaBaugh, 2008). The mini-piezometer consisted of two parts: (1) an inner 5-ft long stainless-steel tube connected to a 4-in. long screen with a drive point, and (2) an outer 4.5 -ft long stainless-steel sheath. To collect a pore-water sample, the screened part of the inner tube was covered with the sheath, and the mini-piezometer was pushed by hand to between 0.5 and $4 \mathrm{ft}$ into the lakebed. The outer sheath was then pulled up, exposing the screen to the lake sediments. Pore water was pumped slowly to minimize surface-water intrusion into the pore-water sample. The field water-quality properties of $\mathrm{pH}$, temperature, specific conductance, and dissolved oxygen concentration were monitored for at least 3 minutes before collecting a sample for laboratory chemical analyses and checked again following sample collection to document potential surface-water intrusion into the pore water.

Groundwater samples were collected from observation, municipal, and domestic wells for analysis of physical properties, major constituents, oxygen-18/oxygen-16 ratio, and deuterium/protium ratio to identify potential surfacewater contribution to the wells. Samples from eight wells in proximity to White Bear Lake were analyzed for major constituents and stable isotopes: four screened in the glacial aquifer, two open to the St. Peter aquifer, and two open to the Prairie du Chien-Jordan aquifer. Samples from an additional six wells open to the glacial, Prairie du Chien-Jordan, or Jordan aquifers were analyzed only for stable isotopes. Submersible pumps already in the wells were used to collect water samples from the domestic and municipal wells. A peristaltic pump was used to collect water samples from the observation wells when the depth to water below the measuring point was less than $25 \mathrm{ft}$. A submersible pump was used to collect water samples from the observation wells when the depth to water below the measuring point was greater than $25 \mathrm{ft}$. Before collecting samples for laboratory analyses, at least three well volumes were pumped from the wells and field properties had stabilized according to the guidelines in the USGS National Field Manual (U.S. Geological Survey, variously dated).

\section{Sample Handling and Analysis}

Onsite water-quality characteristics (water temperature, dissolved oxygen concentration, $\mathrm{pH}$, and specific conductance) were measured for all water samples (except precipitation samples) with a YSI 6820 water-quality multiprobe meter before the collection of samples for laboratory analyses. The specific conductance, $\mathrm{pH}$, and dissolved oxygen probes on the multiprobe meter were calibrated on each of the sampling dates before sampling.

Water samples collected for analysis of anions, dissolved solids, and alkalinity were filtered during sampling through a $0.45-\mu \mathrm{m}$ pore-sized capsule filter and stored in $250-\mathrm{mL}$ polyethylene bottles. Water samples collected for cation analyses were filtered during sampling through a $0.45-\mu \mathrm{m}$ pore-sized capsule filter, preserved with sufficient nitric acid to maintain the $\mathrm{pH}$ at less than 2.0 standard units, and stored in $250-\mathrm{mL}$ acid-rinsed, polyethylene bottles. Unfiltered, unpreserved water samples were collected in $250-\mathrm{mL}$ polyethylene bottles for determining specific conductance and $\mathrm{pH}$ at the USGS National Water-Quality Laboratory (NWQL). All samples were chilled immediately following collection and shipped within 48 hours to the NWQL in Denver, Colorado. Cation and anion concentrations were determined at the NWQL according to methods described in Fishman (1993). Concentrations of alkalinity and bicarbonate were determined by USGS hydrologic technicians through inflection-point titrations performed within 24 hours after sampling (U.S. Geological Survey, variously dated).

Unfiltered, unpreserved samples for determining oxygen-18/oxygen-16 and deuterium/protium (hydrogen-2/hydrogen-1) ratios were collected into $60-\mathrm{mL}$ clear glass bottles, which were capped with polyseal caps, wrapped in electrical tape, and shipped to the USGS Reston Stable Isotope Laboratory in Reston, Virginia. Oxygen-18/oxygen-16 and deuterium/ protium ratios were determined according to the methods described by Révész and Coplen (2008). These isotopes are not measured directly because their concentrations are very low. The oxygen-18/oxygen-16 and hydrogen-2/hydrogen-1 ratios are expressed as values relative to the Vienna Standard Mean Ocean Water-Standard Light Antarctic Precipitation (SLAP) isotope scales (Joint Committee for Guides in Metrology, 2008). The zero of the hydrogen- 2 and oxygen- 18 scales are normalized to the SLAP values of -428 per mil and -55.5 per mil, respectively (Gonfiantini, 1978). Results are reported in units of per mil (parts per thousand). The ratios of the isotopes of oxygen and hydrogen present in water were used to distinguish sources of water when the degree of isotopic fractionation of the water is different for different sources of water. Hydrologic studies have used isotopic ratios in waters to identify groundwater discharge to lakes and sources of waters to wells (Dincer, 1968; Sacks, 2002; Jones, 2006; Rosenberry and LaBaugh, 2008). These isotopes are useful because they are part of the water and not solutes dissolved in the water. If the isotopic compositions of different sources of water are distinct, simple mixing models can be used to identify sources of water. 


\section{Quality Assurance/Quality Control}

Quality assurance and quality control are high priorities for USGS laboratories. The USGS NWQL has a rigorous set of procedures for assuring and controlling the quality of received water samples and analytical results determined by the laboratory (Pirkey and Glodt, 1998). The USGS Reston Stable Isotope Laboratory has an internal quality-assurance policy and works directly with the USGS NWQL to assure the quality of their analytical results (Révész and Coplen, 2008). All the water-quality data and sampling-site information, including quality-assurance and control-sample information, are stored in the USGS National Water Information System (NWIS) database (U.S. Geological Survey, 2012). Field logbooks and electronic field sample forms were used to record onsite water-quality measurements, lake-sediment temperature data, and water-quality instrument calibration data.

Sequential replicate samples were collected following the collection of one groundwater sample, two pore-water samples, and three surface-water samples. A split replicate sample was collected for one precipitation sample. A sequential replicate sample is collected consecutively following the collection of the environmental sample to assess variability among samples resulting from sample collection, processing, shipping, and laboratory procedures performed at different sampling times (U.S. Geological Survey, variously dated). A split replicate sample serves the same purpose but is split from the same water as the original sample rather than being collected following the original sample (U.S. Geological Survey, variously dated). By splitting the replicate sample from the same water as the environmental sample, the split replicate sample can be used to assess sample variability not associated with sample collection. An equipment blank sample also was collected by running inorganic blank water through the mini-piezometer. An equipment blank sample is collected to measure the magnitude of contaminant concentrations that might have been introduced into the sample as a result of using the sample-collection and processing equipment (U.S. Geological Survey, variously dated), which would include the mini-piezometer and sample tubing. The replicate and blank samples were collected following protocols outlined in the USGS National Field Manual for the Collection of Water-Quality Data (U.S. Geological Survey, variously dated).

\section{Near-Shore Hydraulic-Head Differences, Seepage Rates, and Lake-Sediment Characteristics}

Hydraulic-head differences and areas of cool pore water were determined with mini-piezometers and temperature probes along the near-shore perimeter of White Bear Lake. Seepage rates between surface-water and groundwater also were measured in the near-shore margins of the lake. Measurement of head differences and seepage rates provided further information to confirm the location of shallow groundwater inflow to the lake and lake-water discharge to the aquifers. A lake-sediment core was collected from a deeper part of White Bear Lake, and penetration-probe measurements were taken to characterize the thickness and type of lake sediments that may control the amount of lake water flowing to underlying aquifers.

\section{Mini-Piezometer and Seepage-Meter Surveys}

Mini-piezometers were used with manometers to measure hydraulic-head differences between pore waters in lake sediments and lake water (Rosenberry and LaBaugh, 2008). The mini-piezometers provide a comparison between the stage of a surface-water body, such as a lake, and the hydraulic head (water-level elevation) beneath the surface-water body at the depth to which the screen at the end of the probe is driven (Winter and others, 1988). The difference in hydraulic head divided by the distance between the screen and the sedimentwater interface is a measurement of the vertical hydraulic-head gradient. By itself, the device does not give a direct indication of seepage flux. However, hydraulic-head measurements from mini-piezometers can be used in combination with water-flux measurements from a seepage meter to yield information about the hydraulic conductivity of the sediments (Kelly and Murdoch, 2003; Zamora, 2006).

Hydraulic-head differences were measured at 19 of the 25 sites along the lakeshore of White Bear Lake from August 2 through September 1, 2011, where seepage-meter measurements were made (fig. 3). At some sites, multiple measurements of hydraulic-head differences were made. For each measurement, the probe was inserted by hand into the lake sediments as deep as possible and connected to a manometer. The manometer measured small hydraulic-head differences between the pore and lake water. Probe insertion depths into the lake sediments ranged from 0.5 to $4.4 \mathrm{ft}$; the deeper insertion depths were at locations with thick deposits of organic materials. Once the probe was pushed beneath the sedimentwater interface, the outer pipe of the mini-piezometer was retracted to expose the screen. A plastic tube was inserted into the top of the mini-piezometer to connect the probe to one end of a manometer. Another plastic tube connected to the manometer was placed in the lake. A vacuum pump was connected to the manometer to fill the tubing with water from the probe and the surface water. The tubing to the lake was clamped prior to the measurements to develop sufficient suction to pull water through the mini-piezometer screen and tubing. Air bubbles trapped in water in the tubing were removed by physically moving the tubing to aid in bubble release through buoyancy. Once the tubing was full of water and free of bubbles, air was bled into the top of the manometer through the tubing until the menisci are visible in the tubing on both sides of the manometer. The difference in height of the menisci was recorded. This difference equals the difference between hydraulic head in the sediment pore water at the screen and the stage of the lake. 
The flux of water across the sediment-water interface was measured directly using half-barrel, seepage meters between May and September 2011 at 25 sites along the shore of White Bear Lake (fig. 3). Seepage meters are devices that isolate a small area of the bed of a surface-water body and measure the flow of water across that area (Rosenberry and LaBaugh, 2008). A half-barrel, seepage meter consists of a cut-off end of a 55-gal steel (or plastic) storage drum to which a plastic bag is attached to register the change in water volume over the time of bag attachment (Lee, 1977; Lee and Cherry, 1978). At each site, one to six seepage meters were submerged in the lake and placed in the sediment to contain the seepage that crosses that part of the sediment-water interface. A bag containing a known volume of water was attached to the submerged drum for a measured amount of time, after which the bag was removed and the volume of water contained in the bag was remeasured. The change in volume during the time the bag was attached to the drum represented the volumetric rate of flow through the part of the bed covered by the drum (volume per time). The volumetric rate of flow was divided by the approximately 2.7 square foot $\left(\mathrm{ft}^{2}\right)$ area covered by the chamber to yield seepage as a flux velocity (distance per time). Flux velocity normalizes the area covered by the seepage meter and allows comparisons of results with other studies (and other sizes of seepage meters).

One to six seepage meters were installed at each of the 25 sites at White Bear Lake. Each meter made multiple measurements to obtain an average seepage flux rate for each site. A total of 87 seepage-meter measurements were made at 9 sites (fig. 3) from May 1 through 5, 2011. A total of 198 seepage-meter measurements were made at 21 sites from August 2 through September 11, 2011, along the lakeshore of White Bear Lake (site numbers 2, 6, 7-25; table 1-10; gray squares on fig. 3). A median flux was calculated for each site. At the 19 sites where seepage fluxes and hydraulic-head differences were measured, the values of vertical hydraulic conductivity were calculated by applying the following version of Darcy's law:

$$
K_{v}=v \div(H \div d)
$$

where

$\begin{array}{cl}K_{v} & \text { is the vertical hydraulic conductivity, in feet } \\ & \text { per day; } \\ v & \text { is the seepage-meter median flux velocity, in } \\ & \text { feet per day; } \\ H & \text { is the hydraulic-head difference, in feet; and } \\ d & \text { is the mini-piezometer insertion depth, in feet. }\end{array}$

\section{Lake-Sediment Coring/Penetration Probe}

A lake-sediment core was collected and a set of penetration-probe measurements was made by the University of Minnesota, National Lacustrine Core Facility (LacCore) on March 16, 2011, in the southeast part of White Bear Lake (fig. 3). The core was collected and measurements were made to characterize the type of sediments and estimate the maximum thickness of the organic sediments in a deep part of the lake. Commonly, seepage across the sediment-water boundary is limited at deeper depths because thicker accumulations of low-permeable, organic sediment are present (Rosenberry and others, 2000). The core was collected and penetration-probe measurements were made from the top of ice when the lake was frozen.

A bathymetric survey of White Bear Lake completed by the MDNR (Minnesota Department of Natural Resources, 2012) indicated the lake-sediment core was collected near the deepest part of the lake where a steep slope rises toward the east shore (fig. 3). The water depth measured during coring from the bottom of the lake ice was $75.8 \mathrm{ft}$ at the core location. The core was $12.4 \mathrm{ft}$ long and was collected in sections using a Wright-modified Livingstone-type drive rod, piston corer (Wright, 1967); LacCore standard sampling procedures were followed (University of Minnesota, National Lacustrine Core Facility, 2012). Density, electrical resistivity, and magnetic susceptibility logs were performed on the core sections at LacCore. The core sections were then split lengthwise, imaged, and logged for high-resolution, magnetic susceptibility. A composite, depth scale was constructed for the core sections by referencing field notes on the core intervals and correlating similar lithologies from the images of the overlapping sections of the cores. The cores, images, and analytical data were archived in the core archives at LacCore.

A penetration probe was used at 10 sites along a 5,250-ft, northeast-southwest transect in the southeast part of White Bear Lake (fig. 3) to determine maximum penetration depths in the sediments. The penetration probe consisted of a set of connected metal rods that were pushed into the lake sediments at each site until the rods would no longer advance into the sediments. When the rods would no longer advance, the rods were removed, and the total length of penetration was determined from the water surface by subtracting the water depth from the total rod length inserted into the lake and lake sediments. The total length of rod penetration into the sediments was assumed to represent the maximum thickness of the organic sediments on the bottom of the lake. At sites where the water depth was greater than $42.7 \mathrm{ft}$, the rods were inserted into aluminum casing that was placed from the ice surface down to the lake-water-sediment interface to prevent the rods from flexing, thus allowing maximum penetration to be achieved.

\section{Water Balance for March and August 2011}

Monthly water balances for White Bear Lake for the months of March and August 2011 were used to estimate the amount of lake water discharging to glacial buried and bedrock aquifers from the lake for those months. These 2 months were selected for water-balance assessments because groundwater-level data were available from the two synoptic studies 
to estimate the amounts of groundwater inflow to the lake and lake water discharging to shallow aquifers from the lake. Monthly values were determined in acre-feet from hydrologic data collected for the following parameters for the water balance: (1) total precipitation falling directly on the lake $(P)$, (2) total evaporation from the lake surface $(E),(3)$ surfacewater runoff to the lake $(S R)$, (4) groundwater inflow to the lake from glacial water-table aquifers $\left(G W_{i n}\right)$, (5) lake-water discharge to the glacial water-table aquifer $\left(L W_{\text {out } \text { shallow })}\right)$, and (6) change in lake-water volume ( $\triangle L W$ ) (fig. 6). The following water-balance equation (similar to the water-balance equation previously defined for White Bear Lake) was used to estimate the amount of lake water discharging to glacial buried and bedrock aquifers $\left(L W_{\text {out(deep })}\right)$ :

$$
\begin{aligned}
L W_{\text {out (deep })} & =P-\Delta L W+S R+G W_{\text {in }}-E \\
& -L W_{\text {out }(\text { shallow })} \pm E R,
\end{aligned}
$$

where

$$
E R \quad \text { is the water-balance uncertainties. }
$$

Water-balance uncertainties associated with data collection and estimation typically can vary widely (Winter, 1981; Winter and Rosenberry, 2009) depending on the parameter and the methods used to collect the data. For this study, the combined uncertainty for all terms affecting the water balance was assumed to be plus or minus ( \pm ) 10 percent. Monthly values in acre-feet were converted to values in inches over the lake area by dividing the values in acre-feet by a lake area of 2,401 acres (Rice Creek Watershed District, 2011) and multiplying by 12 .

Surface-runoff and evaporation values were only determined for the monthly water balance for August 2011 for White Bear Lake. The lake was frozen for the entire month of March 2011; therefore, these variables were assumed to not contribute or remove water from the lake. Monthly precipitation for March and August 2011 was determined by summing the best daily precipitation data from the high-density network of observation sites closest to White Bear Lake. Monthly surface runoff for August 2011 was estimated by multiplying the direct surface-runoff contributing area to White Bear Lake by a ratio of surface-water runoff to precipitation contributed to the lake determined by MDNR (Minnesota Department of Natural Resources, 1998) and the monthly total precipitation. The direct surface-runoff contributing area for the lake was determined by the Rice Creek Watershed District to be 3,087 acres (Matt Kocian, Rice Creek Watershed District, oral commun., March 24, 2012). An average ratio for 1981-1990 of surface-water runoff to precipitation was determined from results of the MDNR Water Balance Model for White Bear Lake (Minnesota Department of Natural Resources, 1998). This average ratio was multiplied by the monthly precipitation and the direct surface-runoff contributing area to produce an estimate for the monthly surface runoff for August 2011. Monthly evaporation for August 2011 was estimated from daily evaporation data collected from the nearest long-term, class A evaporation pan located approximately $12 \mathrm{mi}$ southwest of White Bear Lake (Minnesota Climatology Working Group, 2011b). The daily evaporation data were totaled for the month and multiplied by an evaporation-pan coefficient of 0.75 to produce a monthly estimate of evaporation from the lake. Class A evaporation-pan coefficients typically range from 0.65 to 0.85 (American Society of Civil Engineers, 1996).

Monthly changes in lake-water volume were estimated for March and August 2011 from water-level data for White Bear Lake obtained from the MDNR (Minnesota Department of Natural Resources, 2012). Monthly changes in water level were determined by estimating water levels on the first and last day of the months. These estimated water levels were compared to the curve of the relation between lake-water volume and lake-water elevation determined by MDNR for White Bear Lake (Minnesota Department of Natural Resources, 1998) to estimate the lake-water volume on the first and last day of March and August 2011. Changes in lake-water volume were estimated by subtracting the volume on the last day from the volume on the first day for the 2 months.

Groundwater inflow to the lake from glacial watertable aquifers was determined for the east and south shores, and lake-water discharge to the glacial water-table aquifer was determined for the west and north shores of White Bear Lake for March and August 2011. Darcy's law was applied to determine groundwater inflow to the lake from glacial water-table aquifers (equation 8 ) and lake-water discharge to glacial water-table aquifers (equation 9) using the following equations:

$$
\begin{gathered}
G W_{\text {in }}=-\frac{K A_{\text {in }} d h}{d l}, \\
L W_{\text {out (shallow) }}=-\frac{K A_{\text {out }} d h}{d l},
\end{gathered}
$$

where

$$
\begin{gathered}
K \quad \begin{array}{c}
\text { is the hydraulic conductivity of the } \\
\text { Quaternary sediments, } \\
A_{\text {in }} \quad \text { is the cross-sectional area to groundwater } \\
\text { inflow from the glacial water-table aquifer } \\
\text { to the lake, }
\end{array} \\
\begin{array}{c}
\text { is the cross-sectional area to lake-water } \\
\text { discharge to the glacial water-table aquifer, } \\
\text { and }
\end{array} \\
\text { is the hydraulic gradient for the glacial water- } \\
\text { table aquifer at the lake. }
\end{gathered}
$$

An average hydraulic conductivity value for Quaternary sediment for the White Bear Lake area was determined from hydraulic conductivity values in the Metro Model 2, a groundwater flow model for the TCMA (Metropolitan Council, 2012) and was used to determine groundwater inflow to the lake and lake-water discharge to the glacial water-table aquifer. The cross-sectional area of groundwater inflow was estimated by multiplying the length of lakeshore where groundwater flows from the glacial water-table aquifer to the lake by the average thickness of the glacial water-table aquifer. Similarly, the 


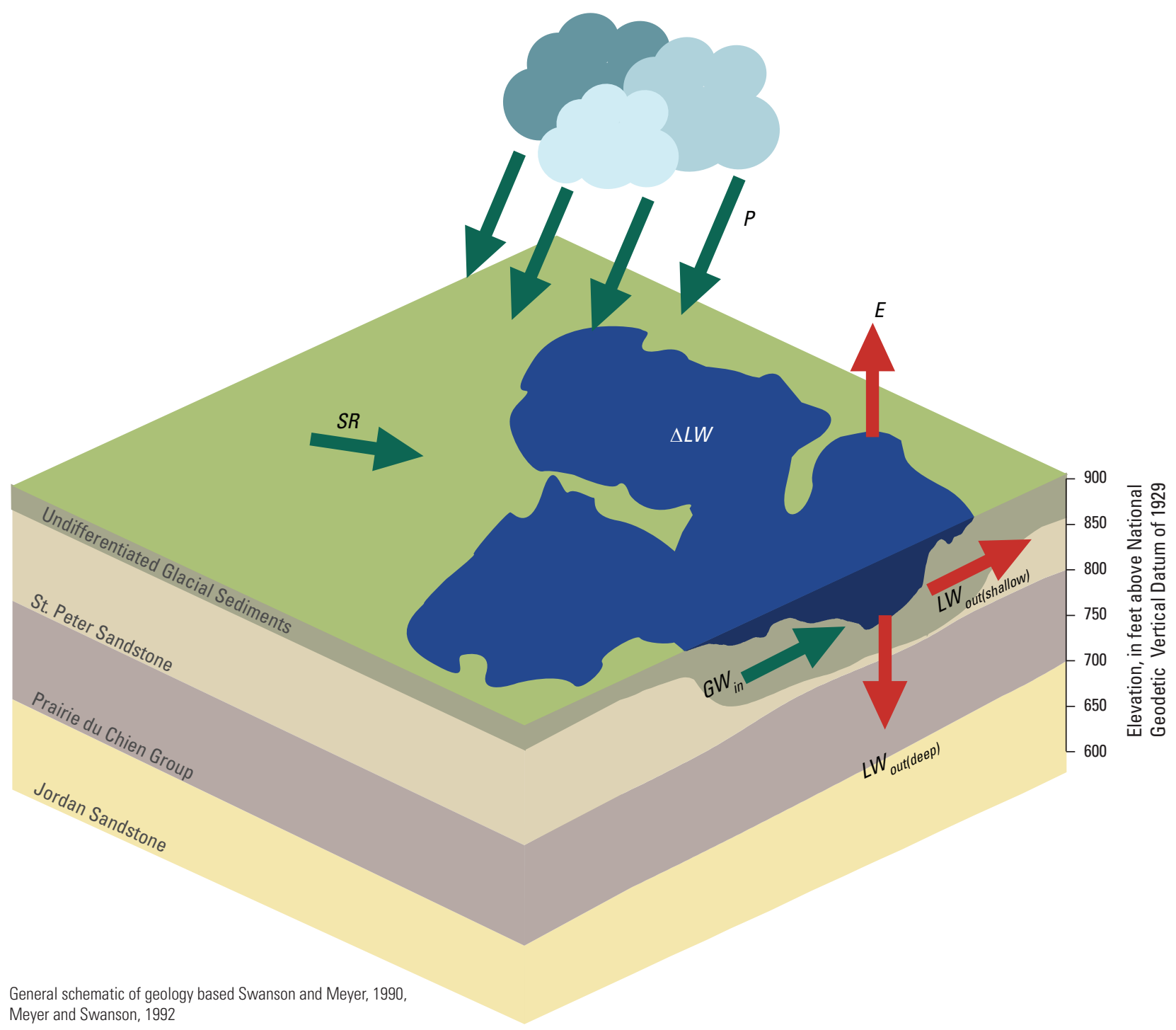

EXPLANATION

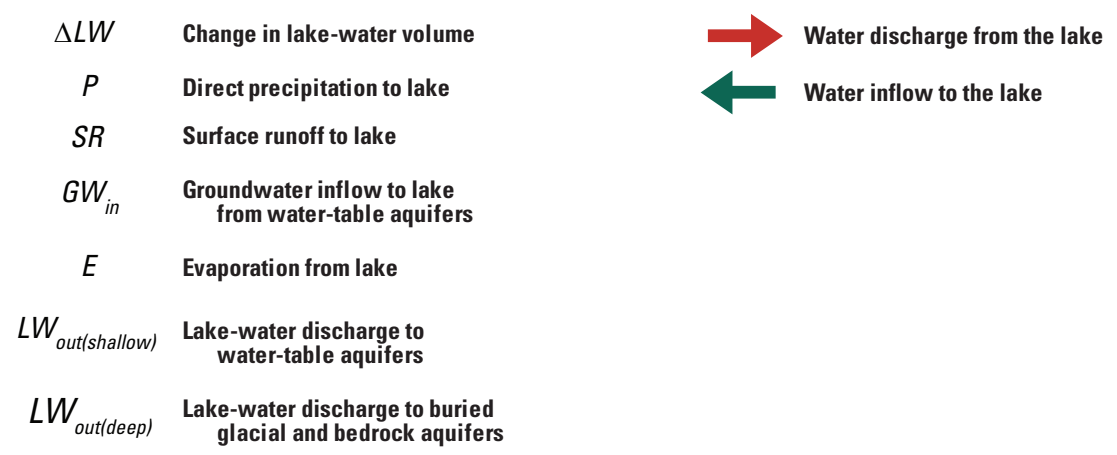

Figure 6. Schematic showing water-balance components for White Bear Lake, northeast Twin Cities Metropolitan Area, Minnesota. 
cross-sectional area of lake-water discharge to aquifers was estimated by multiplying the length of lakeshore where lake water discharges to the glacial water-table aquifer by the average thickness of the glacial water-table aquifer. Potentiometric contours for the glacial water-table aquifer from the March/ April and August 2011 groundwater synoptic studies were compared to the lake level during the synoptic and the existing lakeshore to determine the length of lakeshore where groundwater flow from the glacial water-table aquifer entered the lake and where lake water flowed to the glacial water-table aquifer. The average thickness of the glacial water-table aquifer (24 ft) was determined from geologic logs for wells near White Bear Lake. The hydraulic gradient for the glacial aquifer was determined at 15 locations along the east shore of the lake and 13 locations along the south shore of the lake where groundwater flows into the lake and 8 locations along the west and north shore of the lake where lake water flows to the glacial water-table aquifer. These values were used to determine average hydraulic gradients for east, south, and west/north shores. The average hydraulic gradients were used to estimate groundwater inflows to the lake on the east and south shores and lake-water discharges to the glacial water-table aquifer on the west/north shore.

\section{Groundwater and Surface-Water Interactions}

Analysis of existing long-term lake-level, precipitation, evaporation, groundwater-level, and groundwater-withdrawal data from 1978 to 2011 indicated below normal precipitation could not fully explain the lake-level decline in White Bear Lake from 2003 through 2011. Synoptic, static groundwaterlevel, and lake-level measurements collected in March/April and August 2011 indicated groundwater was potentially flowing into White Bear Lake from glacial aquifers from the northeast and south, and lake water was potentially discharging from White Bear Lake to glacial aquifers to the northwest. Water-quality analyses of pore-water samples in nearshore lake sediments and well-water samples, seepage-meter measurements, and mini-piezometer hydraulic-head measurements also indicated groundwater was potentially flowing into White Bear Lake from glacial aquifers. Static groundwaterlevel measurements in the Prairie du Chien-Jordan aquifer indicated groundwater in the aquifer does not flow into White Bear Lake, but rather lake water likely discharges into the aquifer from the lake. Stable isotope analyses of water samples collected from wells, precipitation, and water from White Bear Lake indicate some wells, completed in either glacial or the Prairie du Chien-Jordan aquifers, downgradient from White Bear Lake were receiving surface water. The lake-core and penetration-probe measurements indicated the amount of organic material generally was low compared to other Minnesota lakes; most of the 12.4-ft core consisted of silts, sands, and gravels that likely slumped from shallower waters. The low amount of organic material and the presence of more permeable, slumped sands and gravels suggested the lakebed may be more permeable in the deep waters than found in many lakes in Minnesota. Water-balance analysis of White Bear Lake in March/April and August 2011 indicates potential discharges of 2.8 and 4.5 in. per month, respectively, over the area of the lake from the lake to the local aquifers.

\section{Historical Changes in Lake Level and Volume of White Bear Lake and Their Relation to Precipitation}

A series of regression analyses were done using historical data to determine the significance of different components of the water balance in explaining historical changes in the water level (and volume) of White Bear Lake. The annual changes in the water level and volume of White Bear Lake during the years 1978 through 2011 were highly correlated [p-values less than $(<) 0.0001]$ with annual precipitation totals measured near the lake (table 4, models 1 and 2), indicating annual fluctuations in lake level (and volume) were highly dependent on local, recent precipitation. Larger amounts of precipitation resulted in larger increases in lake level (and volume) on an annual basis (table 4). Local precipitation input can be an important mechanism in changing the lake level of closed-basin lakes like White Bear Lake (Almendinger, 1990). In the water balance (eq. 1), annual changes in lake level were explained more by the total annual precipitation than by other variables. Surface-water outflow $(S O)$ and lake-surface evaporation $(E)$ were not significant explanatory variables [ $p$-values greater than $(>) 0.05$ ] when included as separate explanatory variables along with precipitation in a multiple linear regression model to explain annual volume change (model in the form of equation 5).

Cumulative lake-level change, precipitation, and evaporation from the lake surface over two example 8-year periods, 1980-1987 and 2003-10, indicate factor(s) other than abnormally dry weather contributed to the most recent lake-level decline. The total precipitation that fell in the White Bear Lake area from 2003 through 2010 was 257.2 in., nearly identical to the total precipitation of 260.8 in. that fell during same length of time between 1980 and 1987 (table 5). Despite this similarity in total precipitation, lake levels decreased by 5.30 $\mathrm{ft}$ from 2003 through 2010 and decreased by only $0.29 \mathrm{ft}$ from 1980 through 1987. Cumulative evaporation totals during 1980-1987 were greater than in 2003-11 (table 5) and do not explain the difference in lake-level change. The region did not undergo a severe drought between 2003 and 2011 (Minnesota Climatology Working Group, 2012b), but the magnitude of the lake-level decline over this period was similar to the decline during the 1987-90 drought (fig. 2; table 5).

ANCOVA (Helsel and Hirsch, 2002) was used to test the hypothesis that the relation between the change in water level (and volume) of White Bear Lake and precipitation is significantly different between two periods: (1) 1978-2002, and 
Table 4. Summaries of linear regression models (significant at alpha $=0.05$ ) between annual changes in lake level or volume and precipitation for White Bear Lake, northeast Twin Cities Metropolitan Area, Minnesota, 1978-2011.

$\left[\mathrm{R}^{2}\right.$, coefficient of determination; $<$, less than $]$

\begin{tabular}{|c|c|c|c|c|c|c|c|c|}
\hline $\begin{array}{l}\text { Model }^{1} \\
\text { number }\end{array}$ & Lake-change source & $\begin{array}{c}\text { Continuous explanatory } \\
\text { variable }\end{array}$ & $\begin{array}{l}\text { Model } \\
\text { adjusted } \\
\mathbf{R}^{2}\end{array}$ & $\begin{array}{l}\text { Model } \\
\text { residual } \\
\text { standard } \\
\text { error }\end{array}$ & Coefficient & Value & $\begin{array}{l}\text { Standard } \\
\text { error }\end{array}$ & $p$-value \\
\hline 1 & $\begin{array}{l}\Delta L W ; \text { annual level } \\
\text { change 1978-2011, } \\
\text { feet }\end{array}$ & $\begin{array}{l}P \text {; High-density pre- } \\
\quad \text { cipitation, nearest, best } \\
\quad \text { available }^{2}\end{array}$ & 0.69 & 0.478 & $\begin{array}{l}b_{0} \\
b_{1}\end{array}$ & -4.29 & 0.49 & $\begin{array}{l}<0.0001 \\
<0.0001\end{array}$ \\
\hline 2 & $\begin{array}{l}\Delta L W ; \text { annual volume } \\
\text { change } 1978-2011, \\
\text { millions of gallons }\end{array}$ & $\begin{array}{l}P \text {; High-density pre- } \\
\quad \text { cipitation, nearest, best } \\
\quad \text { available }^{2}\end{array}$ & 0.48 & 617 & $b_{0}$ & -3090 & 0.24 & $<0.0001$ \\
\hline
\end{tabular}

${ }^{1}$ Model form: $\Delta L W=b_{0}+\left(b_{1} \times P\right)+\varepsilon_{\text {; }}$; where $\Delta L W=$ annual change in lake level or lake volume between January 1 and December 31 of a calendar year; $P=$ precipitation, in inches; $b_{i}=$ estimated coefficients where $b_{0}=$ intercept and $b_{l}=$ slope; and $\varepsilon_{\mathrm{i}}=$ random error (residual), in units of lake change (feet or millions of gallons).

${ }^{2}$ Minnesota Climatology Working Group, 2011a.

Table 5. Cumulative precipitation, evaporation, lake-level change, and groundwater withdrawals for three periods between 1980 and 2010, northeast Twin Cities Metropolitan Area, Minnesota.

\begin{tabular}{lcccccc}
\hline \multicolumn{1}{|c}{ Date range } & Years & $\begin{array}{c}\text { Change in } \\
\text { lake level } \\
\text { (feet) }\end{array}$ & $\begin{array}{c}\text { Precipitation } \\
\text { (inches) }\end{array}$ & $\begin{array}{c}\text { Evaporation } \\
\text { (inches) }\end{array}$ & $\begin{array}{c}\text { Precipitation } \\
\text { minus evapora- } \\
\text { tion (inches) }\end{array}$ & $\begin{array}{c}\text { Withdrawals from Prairie } \\
\text { du Chien-Jordan aquifer } \\
\text { (billions of gallons) }\end{array}$ \\
\hline January 1, 1980, to December 31, 1987 & 8 & -0.29 & 260.8 & 230.0 & 30.8 & 18.8 \\
January 1, 1987, to December 31, 1990 & 4 & -4.81 & 99.5 & 130.0 & -30.5 & 12.4 \\
January 1, 2003, to December 31, 2010 & 8 & -5.30 & 257.2 & 211.5 & 45.7 & 33.9 \\
\hline
\end{tabular}

(2) 2003-11. The fitted $b_{2}$ coefficient of the time-period binary variable $\left(T_{p}\right)$, (eqs. 3 and 4 ) represents the shift or difference between the two periods. For years between 1978 and 2002, the time-period binary variable is 0 , and equation 3 , for example, simplifies to $\Delta L W_{i}=b_{0}+\left(b_{1} \times P_{i}\right)+\varepsilon_{i}$. For years between 2003 and 2011, the binary variable is 1 , and equation 3 simplifies to $\Delta L W_{i}=\left(b_{0}+b_{2}\right)+\left(b_{1} \times P_{i}\right)+\varepsilon_{i}$. The $b_{1}$ coefficient within each ANCOVA model was the same for both periods (tables 1-1 and 1-2 in the appendix).

ANCOVA models constructed with annual data support the likelihood that factor(s) other than abnormally dry weather contributed to the 2003-11 decline in the lake level. The linear relation between the annual change in the lake level at White Bear Lake and annual precipitation is shifted significantly lower $(0.5 \mathrm{ft})$ for the period 2003-11 compared to 1978-2002 (fig. 7A; table $1-1$, model $1, b_{2}$ coefficient). The $-0.5-\mathrm{ft}$ shift corresponds to an average greater loss of $490 \mathrm{Mgal} / \mathrm{yr}$ over the period 2003-11 compared to 1978-2002 at a given annual precipitation amount (table $1-2$, model $1, b_{2}$ coefficient).

The change in the linear relation between lake level and precipitation indicates the average annual amount of precipitation required to maintain the lake level has increased from
33 in. per year during 1978-2002 to 37 in. per year during 2003-11 (fig. 7A). This change is demonstrated by the intersection of the ANCOVA model line for each period with the zero line in figure $7 A$. The zero line represents no net change in lake level between January 1 and December 31 of a calendar year.

The average increased loss of $490 \mathrm{Mgal} / \mathrm{yr}$ from White Bear Lake during 2003-11 (table 1-2, model 1, $b_{2}$ coefficient) indicates other variables in the lake water balance (eq. 1) including surface runoff into the lake $(S R)$, evaporation from the lake surface $(E)$, surface outflow from the lake $(S O)$, and groundwater exchange $\left(G W_{e x}\right)$ have changed relative to precipitation. Since 2003, precipitation amounts that historically maintained the lake level have not been sufficient to maintain the lake at a stable level. Many explanations are possible for this shift, including (1) alterations to the surface watershed that may have reduced the surface runoff $(S R)$ input to the lake, (2) increases in lake-surface evaporation relative to precipitation, and (3) increases in groundwater withdrawals that may have reduced the amount of groundwater inflow to the lake or increased the amount of lake-water discharge to the aquifers, causing a net reduction in the groundwater exchange $\left(G W_{e x}\right)$. 
A. Relation between observed annual (January through December) lake-level changes and precipitation and model fit of analysis of covariance (ANCOVA), 1978-2011

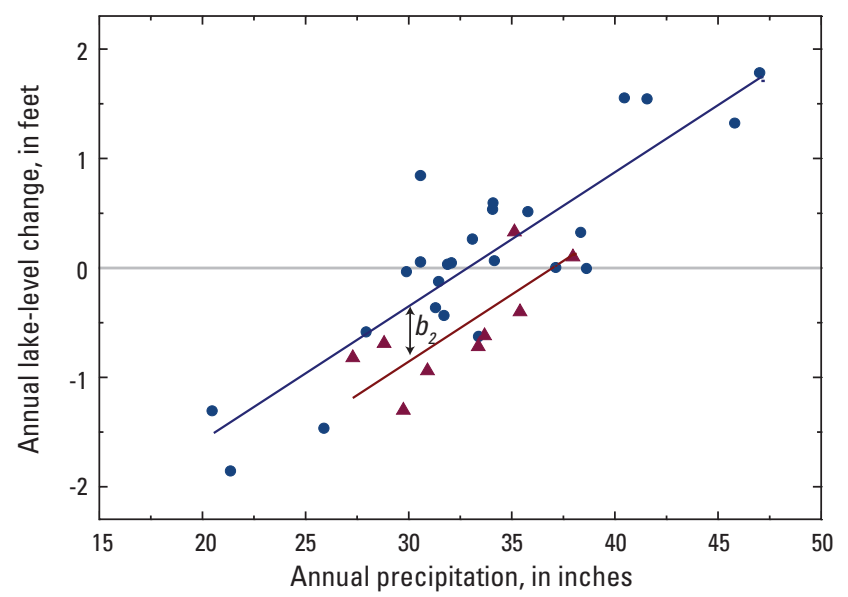

\section{EXPLANATION}

- Observed annual lake-level changes, 1978-2002

A Observed annual lake-level changes, 2003-2010

- ANCOVA model fit, 1978-2002

- ANCOVA model fit, 2003-11

$b_{2}=\mathbf{0 . 5}$ foot (coefficient indicating the intercept difference between periods)

B. Relation between observed annual (January through December) lake-level changes and precipitation minus lake-surface evaporation and ANCOVA model fit, 1978-2011

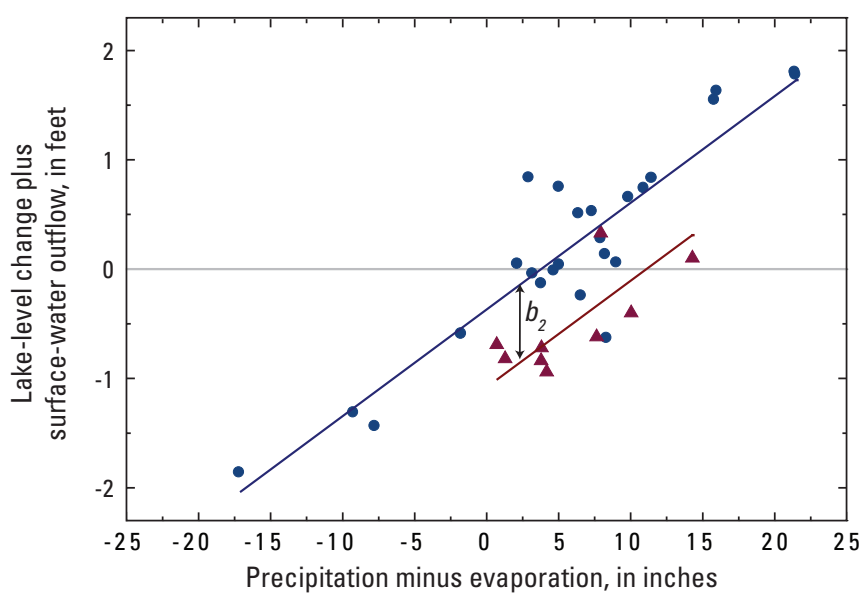

\section{EXPLANATION}

- Observed annual lake-level changes, 1978-2002

A Observed annual lake-level changes, 2003-11

- ANCOVA model fit, 1978-2002

- ANCOVA model fit, 2003-11

$b_{2}=\mathbf{0 . 7}$ foot (coefficient indicating the intercept difference between periods)

C. Observed and model-predicted lake levels, 2003-11

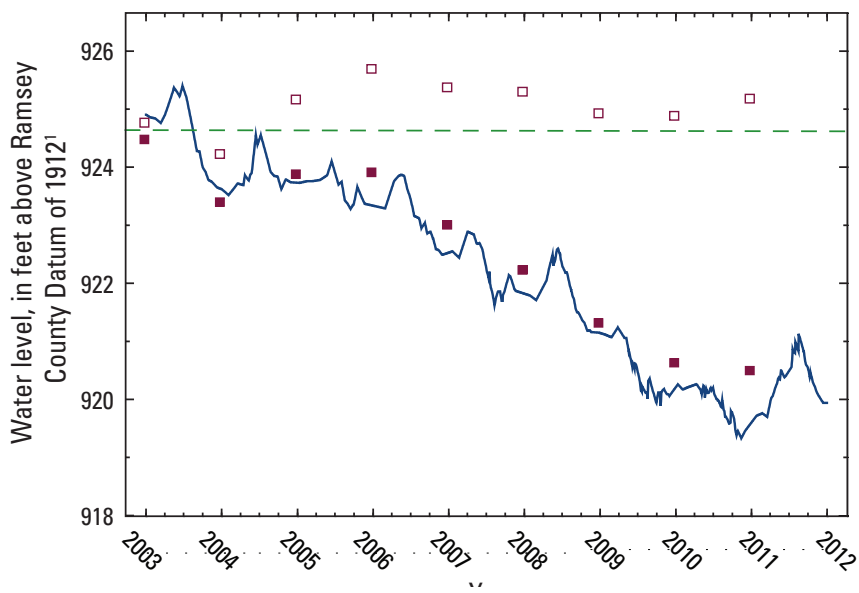

\section{EXPLANATION}

Observed lake level

Lake outflow (924.3 feet above Ramsey County Datum of 1912)

- Predicted lake level on January 1 of each year. 2003-11, using reported annual high-capacity well withdrawals from the Prairie du Chien-Jordan aquifer

ㅁ Predicted lake level on January 1 of each year, 2003-11, using the average annual 1978-2002 high-capacity well withdrawals from the Prairie du Chien-Jordan aquifer

${ }^{1}$ Ramsey County 1912 datum is 0.46 foot lower than NAVD 88.

Figure 7. Analysis of lake-level and precipitation data for White Bear Lake, northeast Twin Cities Metropolitan Area, Minnesota. $A$, Relation between observed annual (January through December) lake-level changes and precipitation and model fit of analysis of covariance (ANCOVA), 1978-2011; $B$, Relation between observed annual (January through December) lake-level changes and precipitation minus lake-surface evaporation and ANCOVA model fit, 1978-2011; and C, Observed and model-predicted lake levels, 2003-11. 
Surface outflow $(S O)$ and evaporation $(E)$ did not explain the increase in volume loss from the lake during 2003-11. This is supported by the significance of the $b_{2}$ coefficient $(p$-value $=0.0008)$ in an ANCOVA model containing $S O$ and $E$ (eq. 4, fig. $7 B$, table 1-2, model 2). An average of $690 \mathrm{Mgal} / \mathrm{yr}$ more was lost from White Bear Lake during the 2003-11 period compared to 1978-2002 with the same amount of precipitation in excess of lake-surface evaporation $(P-E)$ (fig. $7 B$; table 1-2, model 2, $b_{2}$ coefficient). Evaporative losses from the lake surface, estimated by applying a coefficient to measurements of evaporation from the nearest class A pan for the period 2003-11 were not consistently greater than the period 1978-2002 (fig. 2). If evaporative losses had increased relative to precipitation for the period 2003-11, the annual $P-E$ values would be more negative and shifted to the left in figure $7 B$, and the difference between the periods $\left(b_{2}\right.$ coefficient) would be small. The volume difference between the periods, $690 \mathrm{Mgal} / \mathrm{yr}$, corresponds to an average lake-level decline of $0.7 \mathrm{ft}$ (fig. $7 B$; table $1-1$, model $2, b_{2}$ coefficient) that is not explained by precipitation or evaporation.

The increased annual lake-level decline and volume loss from White Bear Lake is concentrated in the spring and summer. During the period 2003-11, an average of $250 \mathrm{Mgal}$ more water was lost each spring than during the period 1978-2002, even though annual precipitation in excess of lake-surface evaporation $(P-E)$ was similar during both periods (table $1-2$, model $3, b_{2}$ coefficient). Similarly, during the period 2003-11, an average of $340 \mathrm{Mgal}$ more water was lost each summer than during the period 1978-2002 (table 1-2, model $4, b_{2}$ coefficient). On average, from 1978 through 2011, the White Bear Lake region received the most precipitation during the summer (13.8 in.), followed by spring ( $8.7 \mathrm{in}$.), fall (7.9 in.), and winter (3.0 in.), which is typical for the region as a whole (Baker and Kuehnast, 1978).

\section{Factors Affecting Water-Level Changes}

Factors affecting water-level changes were evaluated using changes in hydraulic heads and relations between water levels and various water-balance components. Relations between groundwater levels and lake levels, between groundwater withdrawals and water levels, and between other water-balance components and water levels are described.

\section{Relations Between Groundwater Levels and Lake Levels}

Groundwater and lake levels in the White Bear Lake area indicate the lake level in White Bear Lake is strongly associated with the groundwater level in the Prairie du Chien-Jordan aquifer (Minnesota Department of Natural Resources, 1998). Any factor affecting groundwater levels in the Prairie du Chien-Jordan aquifer near White Bear Lake will likely affect the lake level in White Bear Lake. The average annual hydraulic-head difference between White Bear Lake and well 551564 (fig. 1; completed in Prairie du Chien Group) is $15.3 \mathrm{ft}$ for the period of water-level record for that well (1995 through 2011) (figs. 1 and 8). The positive hydraulic-head difference of $15.3 \mathrm{ft}$ indicates the potential for water to discharge from White Bear Lake to the Prairie du Chien-Jordan aquifer.

Groundwater levels in the Prairie du Chien-Jordan aquifer have been responsive to precipitation extremes and groundwater withdrawals and have declined since 2003. Groundwater levels in the Prairie du Chien-Jordan aquifer declined substantially during the 1987-89 drought, as did the water level in White Bear Lake (fig. 8). From 1990 through 1995, water levels in the Prairie du Chien-Jordan aquifer recovered more quickly than the water levels in White Bear Lake and the glacial aquifers (fig. 8, well 244359). In 2002, the region received 45.9 in. of precipitation, causing water levels in White Bear Lake and most observation wells completed in the Prairie du Chien-Jordan aquifer to recover to 1995 levels (fig. 8). In most of the groundwater hydrographs for wells in the Prairie du Chien-Jordan and glacial aquifers, the highest water level before the present downward trend was recorded in 2003 (fig. 8). Short periods of rising water levels have been observed since 2003, but in general, the water levels in White Bear Lake, the glacial aquifers, and the Prairie du Chien-Jordan aquifer have declined.

The hydraulic heads in Prairie du Chien-Jordan aquifer are highest northeast of White Bear Lake and declined the most in that area between 1995 and 2010 despite very wet conditions (fig. 2B). Groundwater levels in observation well 551565 declined by $15.3 \mathrm{ft}$ between October 1995 and October 2010 (fig. 8). This observation well is approximately $5 \mathrm{mi}$ to the northeast of White Bear Lake (fig. 1) and had the highest hydraulic head in the observation wells open to the Prairie du Chien-Jordan aquifer in the northeast TCMA.

Observation wells completed in the Prairie du ChienJordan aquifer near White Bear Lake with periods of record of more than 15 years show evidence of recently being affected by high-capacity groundwater withdrawals in the summer (fig. 8). Water levels observed in the summer have been lower relative to water levels in other seasons within each year from 2003 through 2010. This trend is apparent in several observation wells open to the Prairie du Chien-Jordan aquifer, including observation wells 124395, 208573, 551564, and 481807 (figs. 1 and 8). For each year since 1990, the lowest groundwater levels in these wells typically were observed during June, July, or August. A repeating pattern of summer drawdown was rarely observed before 1990 in the wells with long-term records (fig. 8, wells 124395 and 208573). The nearest high-capacity wells extracting water from the Prairie du Chien-Jordan aquifer in relation to the observation wells are $1.8 \mathrm{mi}$ for observation well 124395, $0.8 \mathrm{mi}$ for well 208573, $0.3 \mathrm{mi}$ for well 551564, and $0.5 \mathrm{mi}$ for well 481807 (fig. 3). 

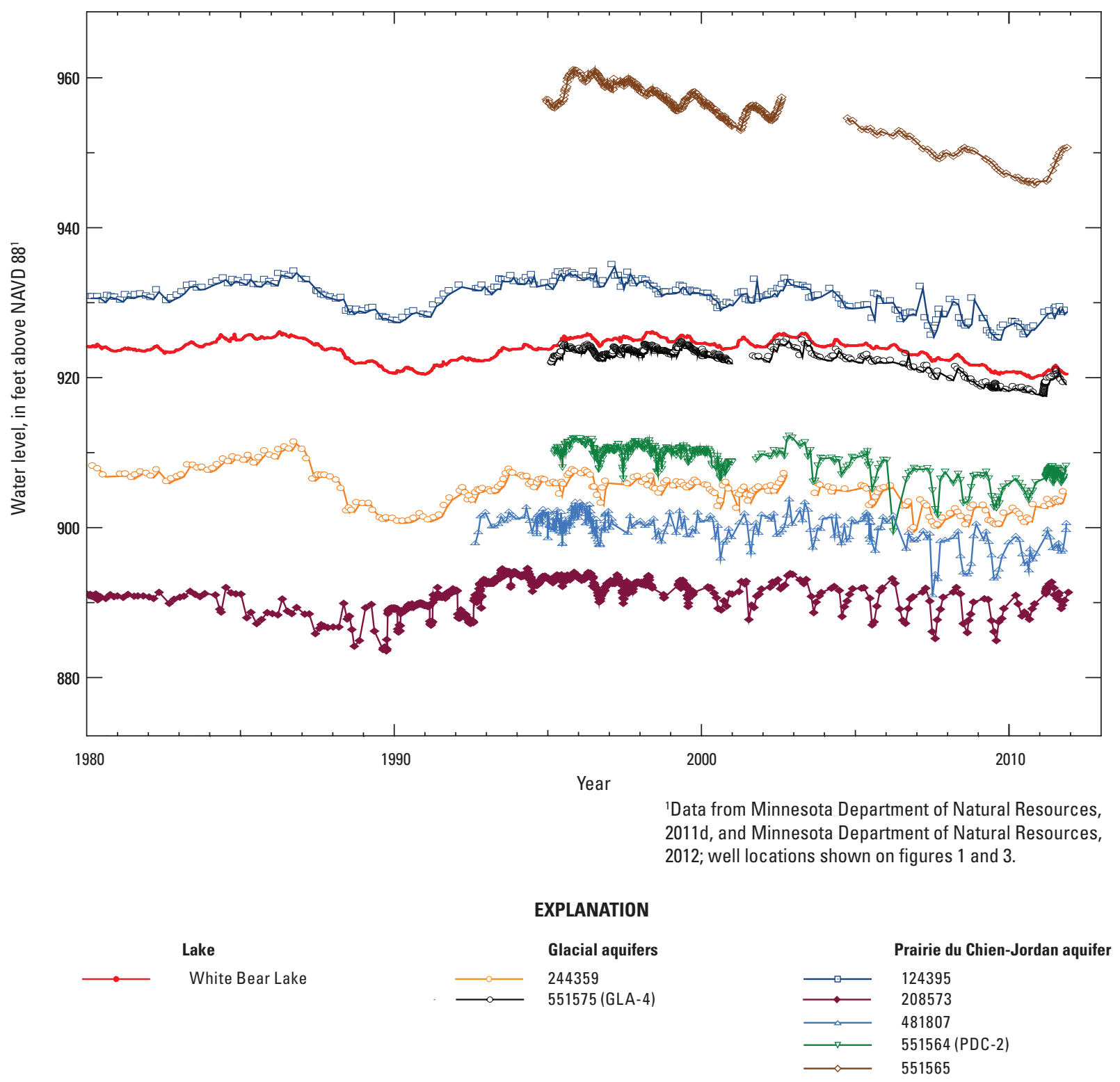

Figure 8. Water-level elevations for White Bear Lake, northeast Twin Cities Metropolitan Area, Minnesota, and Minnesota Department of Natural Resources observation wells open to either the glacial aquifers or the Prairie du Chien-Jordan aquifer, 1980-2011.

Hydraulic-head differences between White Bear Lake and the Prairie du Chien-Jordan aquifer also have increased during the summer months. From 1995 through 2011, the average annual maximum hydraulic-head difference between White Bear Lake and well 551564 (Prairie du Chien Group, portion of the Prairie du Chien-Jordan aquifer) in the summer was $17.6 \mathrm{ft}$; the average difference during non-summer months was $14.9 \mathrm{ft}$. The increased hydraulic-head difference during the summer months potentially increases the amount of leakage of water from overlying aquifers and lakes, including White Bear Lake, to the Prairie du Chien-Jordan aquifer. Increased leakage from White Bear Lake potentially decreases the net groundwater exchange $\left(G W_{\mathrm{ex}}\right)$ for the lake during the summer compared to the other seasons.

\section{Trends in Groundwater Withdrawals}

Total annual groundwater withdrawals through highcapacity wells in the study area increased from a minimum of 2,607 Mgal in 1980 to a maximum of 6,053 Mgal in 2007 (figs. $9 A$ and $9 B$ ). For comparison, the average volume of White Bear Lake from 1980 to 2010 was 14,670 Mgal. Groundwater withdrawals by municipalities have accounted for an increasing percentage of high-capacity withdrawals. The percentage of total groundwater withdrawals by the northeast TCMA municipalities (Centerville, Columbus, Forest Lake, Hugo, Lino Lakes, Mahtomedi, North St. Paul, Vadnais Heights, White Bear Lake, and White Bear Township) from the total high-capacity well withdrawals in the study 
area increased from 67 percent in 1980 to 86 percent in 2010 . Annual groundwater withdrawals for non-municipal uses have not substantially increased since 1980 (fig. 9A). Annual groundwater withdrawals from high-capacity wells open to the glacial aquifers, St. Peter aquifer, and multiple aquifers showed no substantial increase since 1980 (fig. 9B).

The increase in municipal groundwater withdrawals was associated with a higher demand from a growing population in the northeast TCMA that used more water per person (table 6). From 1980 to 2010, the combined population total of the northeast TCMA municipalities nearly doubled (table 6; U.S. Census Bureau, 2012). During this same time, the annual per capita municipal groundwater withdrawals from all aquifers increased from 77 gal per person per day in 1980 to $92 \mathrm{gal}$ per person per day in 2010 . Since 1990 , per capita municipal groundwater withdrawals increased much more in the summer than in the other seasons (table 6).

Most of the groundwater withdrawals in the study area were from the Prairie du Chien-Jordan aquifer. Annual groundwater withdrawals from the Prairie du Chien-Jordan aquifer have more than doubled from 1980 through 2010, increasing from a minimum of $1,873 \mathrm{Mgal}$ in 1980 to a maximum of 4,557 Mgal in 2007 (fig. 9B). From 1980 through 2010, 83 percent of the total groundwater withdrawn within the study area was from the Prairie du Chien-Jordan aquifer. Municipal groundwater withdrawals account for 84 percent of the total Prairie du Chien-Jordan withdrawals from 1980 through 2010; the other 16 percent was withdrawn for other uses, such as industrial processing and irrigation of golf courses (fig. 9B).

Increases in groundwater withdrawals from the Prairie du Chien-Jordan aquifer are correlated with time and dry weather (table 1-3 in the appendix, models 3-7). From 1980 through 2010, annual groundwater withdrawals from the Prairie du ChienJordan aquifer increased by an average of $82 \mathrm{Mgal} / \mathrm{yr}$ (table 1-3, model $3, b_{1}$ coefficient). Annual groundwater withdrawals from the Prairie du Chien-Jordan aquifer also increased under dry conditions, averaging an increase of $25 \mathrm{Mgal}$ (table 1-3, model 3, $b_{2}$ coefficient) for every inch of precipitation less than the 1980 2010 record high of $47.09 \mathrm{in}$., which occurred in 1991.

Groundwater withdrawals from the Prairie du ChienJordan aquifer during the summer accounted for more of the annual increase in withdrawals than any other season (fig. $9 \mathrm{C}$ ). From 1988 through 2010, groundwater withdrawals during the summer accounted for 39 percent of the total groundwater withdrawals from the Prairie du Chien-Jordan aquifer; spring, fall, and winter withdrawals accounted for 22, 23, and 17 percent of the total, respectively. From 1988 through 2010, groundwater withdrawals from the Prairie du Chien-Jordan aquifer increased each year by an average of $37 \mathrm{Mgal}$ in the summer, $17 \mathrm{Mgal}$ in the fall, $13 \mathrm{Mgal}$ in the spring, and $6 \mathrm{Mgal}$ in the winter (table 1-3, models 4-7, $b_{1}$ coefficients). In the TCMA, summer water demand averages 2.6 times the winter demand; most of the summer peak demand was for landscape irrigation (Minnesota Department of Natural Resources, 2005).

Seasonal groundwater withdrawals increased as seasonal precipitation decreased, especially in the summer.
Groundwater withdrawals from the Prairie du Chien-Jordan aquifer during the summer increased by an average of $32 \mathrm{Mgal}$ (table 1-3, model 5, $b_{2}$ coefficient) for every inch of precipitation below the maximum 1988-2010 summer precipitation total of 24.39 in., which was in 1993. Groundwater withdrawals from the Prairie du Chien-Jordan aquifer during the spring increased by an average of $12 \mathrm{Mgal}$ (table 1-3, model 4, $\mathrm{b}_{2}$ coefficient) for every inch of precipitation below the maximum 1988-2010 spring precipitation total of 16.41 in., which was in 1991. Groundwater withdrawals from the Prairie du Chien-Jordan aquifer during the fall tended to increase by an average of $12 \mathrm{Mgal}$ (table $1-3$, model $6, b_{2}$ coefficient) for every inch of precipitation below the maximum 1988-2010 fall precipitation total of 14.27 in., which was in 1991.

\section{Relations Between Water-Balance Components, Groundwater Withdrawals, and Water Levels}

Annual groundwater withdrawals from the Prairie du Chien-Jordan aquifer $\left(W_{P D C J, i}\right)$ near White Bear Lake were used in place of time period $\left(T_{p}\right)$ in equation 4 to explain the annual lake-volume changes according to the following multiple linear regression model:

$$
\begin{gathered}
\left(\Delta L W_{i}+S O_{i}\right)=b_{0}+\left[b_{1} \times\left(P_{i}-E_{i}\right)\right]+ \\
{\left[b_{2} \times W_{P D C J, i}\right]+\varepsilon_{i},} \\
i=1980,1981, \ldots, 2010
\end{gathered}
$$

where

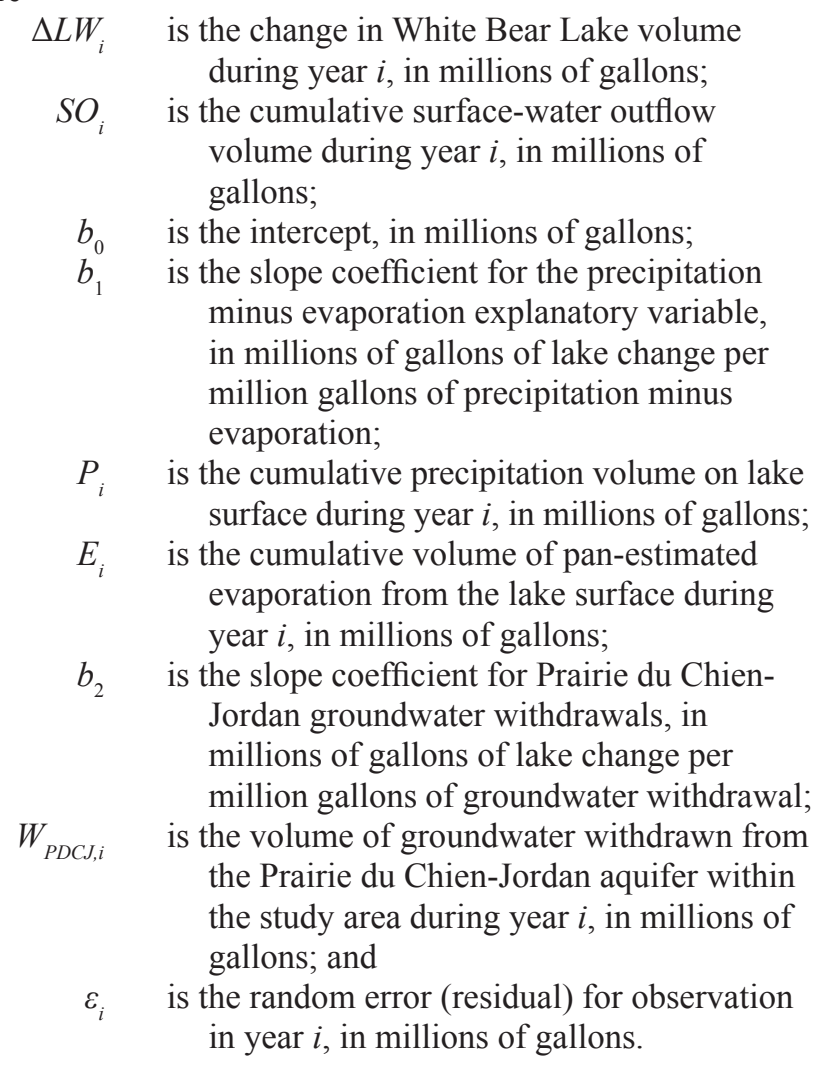


A. Annual groundwater withdrawals by high-capacity wells for municipal and other uses, 1980-2010

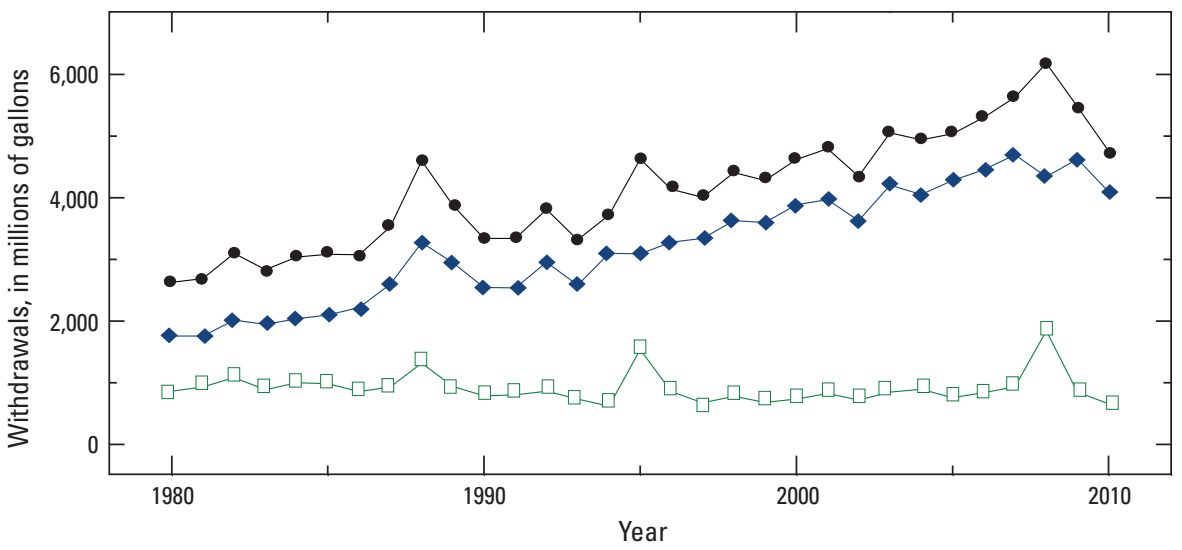

EXPLANATION

- Total

- Municipal

$\square$ Other

B. Annual groundwater withdrawals by high-capacity wells from Quaternary, St. Peter, Prairie du Chien-Jordan, and multiple aquifers, 1980-2010

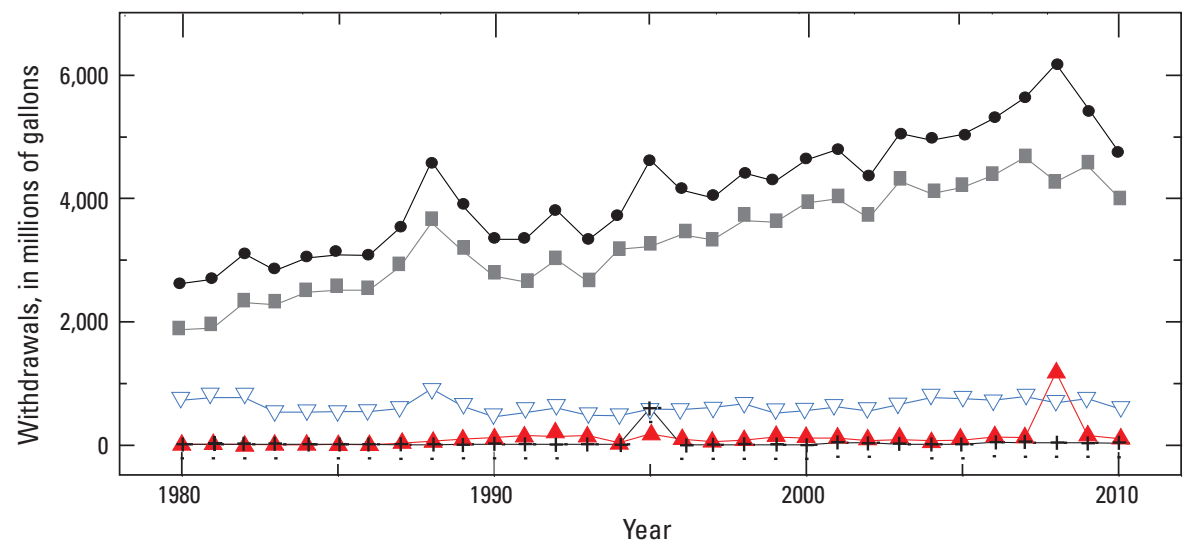

EXPLANATION

- Total

- Glacial aquifers

+ St. Peter aquifer

- Prairie du ChienJordan aquifer

Multiple aquifers

C. Seasonal groundwater withdrawals by high-capacity wells from the Praire du Chien-Jordan aquifer 1988-2010

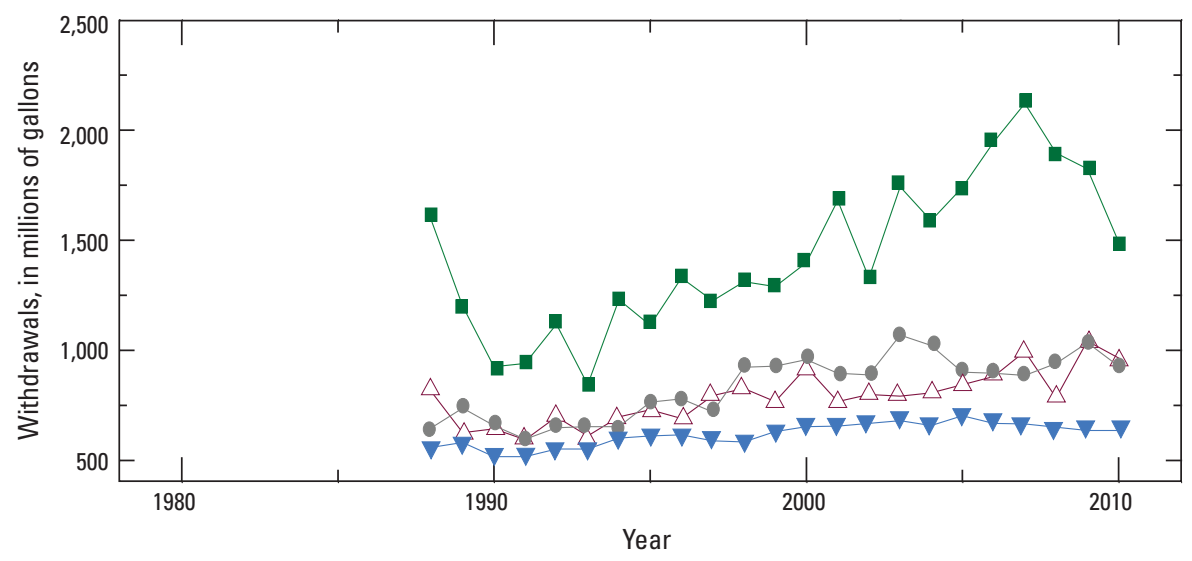

EXPLANATION

Spring (March, April, May)

- Sum mer (June, July, August)

- Fall (September, October, November)

$\nabla$ W inter (December, January, February)

Figure 9. Groundwater withdrawals by high-capacity wells near White Bear Lake, northeast Twin Cities Metropolitan Area, Minnesota (data from Minnesota Department of Natural Resources, 2011b). A, Annual withdrawals for municipal and other uses, 1980-2010; B, Annual withdrawals from glacial, St. Peter, Prairie du Chien-Jordan, and multiple aquifers, 1980-2010; and C, Seasonal withdrawals from the Prairie du Chien-Jordan aquifer, 1988-2010. 
Table 6. Total annual and seasonal municipal groundwater withdrawals in 1980, 1990, 2000, and 2010 for the municipalities of Centerville, Columbus, Forest Lake, Hugo, Lino Lakes, Mahtomedi, North St. Paul, Vadnais Heights, White Bear Lake, and White Bear Township, northeast Twin Cities Metropolitan Area, Minnesota.

$[--$, no data $]$

\begin{tabular}{|c|c|c|c|c|c|c|}
\hline \multirow{2}{*}{ Year } & \multirow{2}{*}{ Population ${ }^{1}$} & Annual & Spring & Summer & Fall & Winter \\
\hline & & \multicolumn{5}{|c|}{ Per capita withdrawals, in gallons per day ${ }^{2}$} \\
\hline 1980 & 64,317 & 77 & -- & -- & -- & -- \\
\hline 1990 & 85,640 & 85 & 78 & 113 & 81 & 68 \\
\hline 2000 & 105,348 & 98 & 86 & 141 & 96 & 71 \\
\hline 2010 & 125,813 & 92 & 81 & 141 & 85 & 61 \\
\hline
\end{tabular}

${ }^{1}$ From U.S. Census Bureau, 2012.

${ }^{2}$ From Minnesota Department of Natural Resources, 2011b.

Equation 10 demonstrates that two variables, annual precipitation minus evaporation $\left(P_{i}-E_{i}\right)$ and annual withdrawals from the Prairie du Chien-Jordan aquifer $\left(W_{P D C J, i}\right)$, were important for explaining annual changes in the lake volume (including surface outflow) for 1980-2010 (eq. 10; table 1-3, model 1). The coefficients of these explanatory variables were highly significant in equation 10 with $p$-values of $<0.0001$ and 0.0035 , (table $1-3$, model $1, b_{1}$ and $b_{2}$ coefficients). Equation 10 explained more variability in the annual changes in lake level than a model only containing the precipitation minus evaporation variable $\left(P_{i}-E_{i}\right)$; the addition of groundwater withdrawn from the Prairie du Chien-Jordan aquifer $\left(W_{P D C J, i}\right)$ improved the model $\mathrm{R}^{2}$ from 0.64 to 0.72 .

Groundwater withdrawals at near-average precipitation can explain the increased volume loss from White Bear Lake during 2003-10. The previously discussed ANCOVA models identified a significantly greater volume loss from White Bear Lake during 2003-11 compared to 1978-2002 (tables 1-1 and 1-2). These models did not identify a reasonable cause for that difference, just that a difference existed. Equation 10 identified a significant correlation between annual changes in lake volume (including surface outflow) and two variables:

(1) precipitation minus evaporation $\left(P_{i}-E_{i}\right)$ and (2) withdrawals from the Prairie du Chien-Jordan aquifer $\left(W_{P D C J, i}\right)$. The time period variable $\left(T_{p}\right)$ was not significant $(p$-value $=0.10)$ when added to equation 10 as an explanatory variable. Furthermore, an analysis of variance (ANOVA) on the sequential addition of explanatory variables indicates that time period $\left(T_{P}\right)$ does not significantly improve the model that already includes the $(P-E)$ and $W_{P D C J}$ variables (table $1-4$ in the appendix). These statistical tests indicate withdrawals from the Prairie du ChienJordan aquifer can explain the increased volume loss from White Bear Lake during 2003-10.

The significance of annual groundwater withdrawals from the Prairie du Chien-Jordan aquifer (near White Bear Lake) in explaining annual changes in lake level agrees with the following previously discussed observations: (1) a strong association exists between the water levels in White
Bear Lake and the Prairie du Chien-Jordan aquifer (fig. 8), (2) lower groundwater elevations were measured in the Prairie $\mathrm{du}$ Chien-Jordan aquifer during the summers since 2003 (fig. 8), and (3) groundwater withdrawals have increased from the Prairie du Chien-Jordan aquifer from 1980 through 2010 (fig. 9). Groundwater withdrawals from the Prairie du Chien-Jordan aquifer during 2003-10 were the highest ever recorded (fig 9). The withdrawals, coupled with near-average precipitation, during 2003-10 could have caused the lowering of the potentiometric surface of the Prairie du Chien-Jordan aquifer over that period and the lowering of White Bear Lake. In equation 10, the effect of the groundwater withdrawals on the lake level is realized through a more negative groundwater exchange $\left(G W_{e x}\right)$ in the lake water balance (eq. 1).

The coefficients from a lake-level regression model similar to equation 10 were used to predict annual lake-level changes plus surface outflow (in feet of lake level) for the period beginning January 1, 2002, through January 1, 2011 (table 1-3, model 2, fig. 7C). The following equation utilized the coefficients estimated in model 2 (table 1-3) to predict the water level in White Bear Lake on January 1 of each year from 2003 through 2011:

$$
\begin{gathered}
\hat{L}_{i+1}=\mathrm{L}_{2002}+0.85(i+1)+0.099 \sum_{i=0}^{n}\left(P_{i}-E_{i}\right)- \\
4.3 \times 10^{-4} \sum_{i=0}^{n} W_{P D C J, i}-\sum_{i=0}^{n} S O_{i}
\end{gathered}
$$

where

$$
\begin{aligned}
& \hat{L}_{i+1} \quad \text { is the predicted lake level, including surface } \\
& \mathrm{L}_{2002} \text { is the interpolated lake level of } 923.59 \mathrm{ft}
\end{aligned}
$$

Equation 11 predicted the amount of precipitation in excess of evaporation was not sufficient to increase the lake level for 6 of the 9 years between January 1, 2002, and January 1, 2011, at reported groundwater withdrawal volumes from the Prairie du Chien-Jordan aquifer. 
Equation 11 predicted a cumulative change in lake level of -2.94 ft between January 1, 2002, and January 1, 2011. When the average annual groundwater withdrawal volume of 2,982 Mgal for the period 1980-2002 was used in equation 11 in place of the reported groundwater withdrawals, the predicted cumulative change in lake level was $1.65 \mathrm{ft}$ over the same period. The difference between these two predictions in cumulative lake-level change (-2.94 and $1.65 \mathrm{ft})$ is $4.59 \mathrm{ft}$, which corresponds to about $0.5 \mathrm{ft}$ of lake-level loss per year explained by groundwater withdrawals above the 1980-2002 annual average (fig. $7 \mathrm{C}$ ).

The surface runoff $(S O)$ term was not explicitly tested separate from the $G W_{e x}$ term in this regression model because (1) no known historical surface-runoff measurements were collected between 1980 and 2010 to quantify the amount of surface runoff entering the lake, and (2) previous studies indicated surface runoff to White Bear Lake is a minor component to the overall water budget of the lake. Using a lake water-balance model, the Minnesota Department of Natural Resources (1998) determined surface runoff contributed 16 percent of the total average inflow of water to the lake between 1981 and 1990. This total average inflow was equal to the sum of the average annual direct precipitation and surface runoff to the lake and did not include the amount of groundwater entering the lake. The watershed area for White Bear Lake includes many closed basins that do not contribute surface runoff directly to White Bear Lake. The contributing area for surface runoff for White Bear Lake was estimated to be 3,087 acres (Matt Kocian, Rice Creek Watershed District, oral commun., March 24, 2012), which represents approximately 66 percent of the entire watershed area for White Bear Lake.

The regression model constructed with annual lake-level change, precipitation minus evaporation, and groundwater extracted from the Prairie du Chien-Jordan aquifer provides a reasonable explanation of level changes in White Bear Lake, but it is not intended to be a predictive tool. Precipitation and groundwater withdrawals affect groundwater levels, which, in turn, affect the White Bear Lake levels. The model is a simple correlation between variables that have a reasonable basis for affecting lake levels, but it does not account for spatial and temporal differences in these parameters. Other models, such as a groundwater flow model derived from physical flow equations, would be needed to account for the spatial and temporal effects of groundwater extracted from the Prairie du Chien-Jordan aquifer on the lake level. The regression model assumes that the lake-level change each year is independent and considers all pumping wells equally within the study area, no matter the distance from the lake. High-capacity wells closer to the lake likely would affect the lake levels more than wells farther from the lake. The regression model also does not take into account the possible effects of broader regional withdrawals from beyond the study area that may affect the potentiometric surface in the Prairie du Chien-Jordan aquifer and subsequently the lake levels.

Groundwater inflow, surface-water runoff, evaporation, and other hydrologic variables in the water balance of the lake likely play a smaller role in the recent lake-level decline compared to groundwater withdrawals. Since 2003, groundwater levels in the glacial water-table and buried aquifers in the White Bear Lake area decreased more than $4 \mathrm{ft}$ in MDNR observation wells south of the lake (Minnesota Department of Natural Resources, 2011d), potentially decreasing groundwater inflow to White Bear Lake. Because no synoptic groundwaterlevel and surface-water outflow data were available for 2003 in the White Bear Lake area, it is difficult to estimate changes in total groundwater inflow rates to the lake from 2003 through 2011. However, an estimate of the changes in total groundwater inflow rates to the lake from 2003 to 2011 was made on the basis of the following assumptions: (1) groundwater levels in the glacial water-table aquifer were $4 \mathrm{ft}$ higher in 2003 than in 2011 , (2) a thickness of $4 \mathrm{ft}$ of additional glacial material could contribute more groundwater to the lake in 2003 than in 2011, and (3) the lake maintained a water level equal to the lake outlet elevation of $924.3 \mathrm{ft}$ (fig. 2). Making these assumptions and following the procedures for determining groundwater inflow rates to the lake described in the Water Balance for March and August 2011 section of this report, estimates of monthly groundwater inflow from the glacial water-table aquifer to the lake for March and August 2003 would be 2.4 and 2.3 in., respectively, over the area of White Bear Lake (2,401 acres, Rice Creek Watershed District, 2011). These 2003 monthly groundwater inflows would only account for 5 and 6 percent of additional water to the estimates of total monthly inflow to the lake for March and August 2011, respectively. These estimates are relatively small changes to the overall water balance of the lake.

Installation of rain gardens and other infiltration basins, and changes in stormwater/sewer discharge to White Bear Lake may have reduced the amount of surface-water runoff reaching the lake, but only to a minor extent. Only approximately 3 percent ( 85 acres) of the total surface-water runoff contributing area of White Bear Lake (3,087 acres) is affected by infiltration practices associated with rain gardens, infiltration basins, pervious pavement, and other infiltration methods (Matt Kocian, Rice Creek Watershed District, written commun., February 13, 2012). Water that enters rain gardens or infiltration basins leaves the gardens or basins either through evaporation, transpiration of plants, or seepage into local groundwater. Water seeping from rain gardens or infiltration basins into local groundwater within the groundwater watershed of White Bear Lake will flow toward and eventually enter the lake as groundwater inflow. Municipal storm-sewer maps for communities discharging stormwater to White Bear Lake indicate very few changes in the routing of discharge since 1980.

Results from the ANCOVA model using data for annual and seasonal lake levels and precipitation minus evaporation indicated changes in evaporation from the lake surface could not alone account for the decline in the water level for White Bear Lake. Evaporation rates from the lake surface did vary seasonally and annually. Annual pan-evaporation rates at the St. Paul Campus Climatological Observatory from 
1980 to 2010 ranged from 23.7 to 38.6 in. (Minnesota Climatology Working Group, 2011b). When these annual evaporation variations were included in the ANCOVA model using data for annual lake levels and annual precipitation minus evaporation, a significant difference existed in the relation from 2003 through 2011 compared with 1978 through 2002. This indicates changes in the annual precipitation and evaporation could not fully explain the annual lake-level changes.

\section{Groundwater Flow and Regional Surface-Water and Groundwater-Level Changes in 2011}

Groundwater levels of the glacial aquifers (water-table and buried), St. Peter aquifer, and Prairie du Chien-Jordan aquifer and surface-water levels were determined through groundwater-level synoptic studies during two seasons, spring (March/April) and summer (August), in 2011 across a network of wells and lakes (table 2; fig. 5, tables 1-5, 1-6, 1-7, and 1-8 in the appendix). Potentiometric contour maps for each of the four aquifers were constructed from these data. The potentiometric contours were used to indicate the direction of groundwater flow near White Bear Lake. The differences in water levels between March/April and August 2011 were calculated to determine differences in hydraulic gradients.

\section{Glacial Aquifers}

Potentiometric contours for the glacial water-table aquifer indicate groundwater tends to flow toward White Bear Lake from the south, east, and northeast, and groundwater flows to the northwest away from the lake on the north and northwest end of the lake toward Bald Eagle Lake (fig. 10). The potentiometric map for the glacial water-table aquifer for March/ April 2011 was constructed from water levels measured in 13 wells and 66 lakes in March and April 2011 (tables 2, 1-5, and 1-7). The potentiometric map constructed using water levels in 13 wells and 68 lakes in August 2011 was similar to the March/April 2011 potentiometric map and is not shown. The highest water levels measured for both March/April $(995.92 \mathrm{ft}$ above NAVD 88) and August (996.26 ft above NAVD 88) were in Echo Lake approximately $2 \mathrm{mi}$ south-southeast of White Bear Lake (fig. 10). The lowest water levels were in Kohlman Lake in March/April (859.12 ft above NAVD 88; fig. 10) and in Kohlman Lake and Keller Lake in August (858.48 ft above NAVD 88; fig. 10). Kohlman Lake and Keller Lake are connected by surface-water channels to Lake Gervais (fig. 1). The groundwater contributing area for White Bear Lake for the glacial water-table aquifer incorporates approximately 12.7 and 12.8 square miles $\left(\mathrm{mi}^{2}\right)$ for March/April and August 2011, respectively, around the lake. The highest hydraulic gradients in the glacial aquifer were between Echo Lake and White Bear Lake (fig. 10).

Small rises or declines (less than $2 \mathrm{ft}$ ) were observed in the groundwater levels for the water-table aquifer throughout most of the study area between March/April and August
2011. The large amount of precipitation in July and early August 2011 may have reduced the amount of change in the groundwater levels. The largest increase in groundwater level (3.9 ft) between March/April and August 2011 was recorded in a well in the southern part of the study area; the largest decline in water level (1.2 ft) was recorded near East Vadnais Lake. The city of St. Paul draws a part of their municipal water supply from East Vadnais Lake, which, with high summer water demand, may explain the large water-level decline in the lake and surrounding water-table aquifer.

A potentiometric map for the glacial buried aquifer (not shown) was constructed from groundwater levels measured in 46 and 51 wells in March/April and August 2011, respectively (table 2). All the potentiometric contours determined for this aquifer were only estimated contours because the hydrologic connection between the glacial water-table aquifer and glacial buried aquifer was not known through much of the study area. A comparison of potentiometric contours between the glacial water-table aquifer and glacial buried aquifer indicated groundwater levels generally were 10 to $25 \mathrm{ft}$ higher in the water-table aquifer than in the buried aquifer. At the nested MDNR observation wells west of Goose Lake (fig. 1), the groundwater levels in the well screened in the water-table aquifer (observation well 227977, fig. 1) were 16.06 and $17.42 \mathrm{ft}$ higher than groundwater levels in the well screened in the buried aquifer (observation well 244359, fig. 1) in March/ April and August 2011, respectively. The highest groundwater levels in the glacial buried aquifer were measured in a well in the southern part of the study area near Silver Lake, approximately 3.5 mi south of White Bear Lake (fig. 1). In March/ April and August, water levels in this well were 971.75 and $978.34 \mathrm{ft}$ above NAVD 88, respectively. The lowest groundwater levels in the aquifer in March/April (839.36 ft above NAVD 88) and August (841.02 ft above NAVD 88) were in observation well 244345 in Maplewood, Minnesota in the southwestern part of the study area approximately $2 \mathrm{mi}$ southeast of Keller Lake (fig. 1).

Groundwater in the glacial buried aquifer flows from east, southeast, and south toward White Bear Lake, and groundwater to the northwest flows away from the lake. The groundwater contributing area for White Bear Lake for the buried aquifer was smaller than the contributing area for the watertable aquifer, incorporating approximately 4.3 and $5.6 \mathrm{mi}^{2}$ for March/April and August 2011, respectively (contributing area for March/April 2011 shown in fig. 10). Accounting for the overlapped parts of the contributing areas between both glacial aquifers, the total groundwater contributing area to White Bear Lake from the glacial aquifers was approximately 13.0 and $13.1 \mathrm{mi}^{2}$ for March/April and August 2011, respectively.

Similar to the glacial water-table aquifer, only small rises or declines (less than $2 \mathrm{ft}$ ) were observed in the groundwater levels for the glacial buried aquifer throughout most of the study area between March/April and August 2011. Groundwater levels rose more than $2 \mathrm{ft}$ in the buried aquifer south of White Bear Lake; groundwater levels declined west of White Bear Lake and in Circle Pines and Lino Lakes 


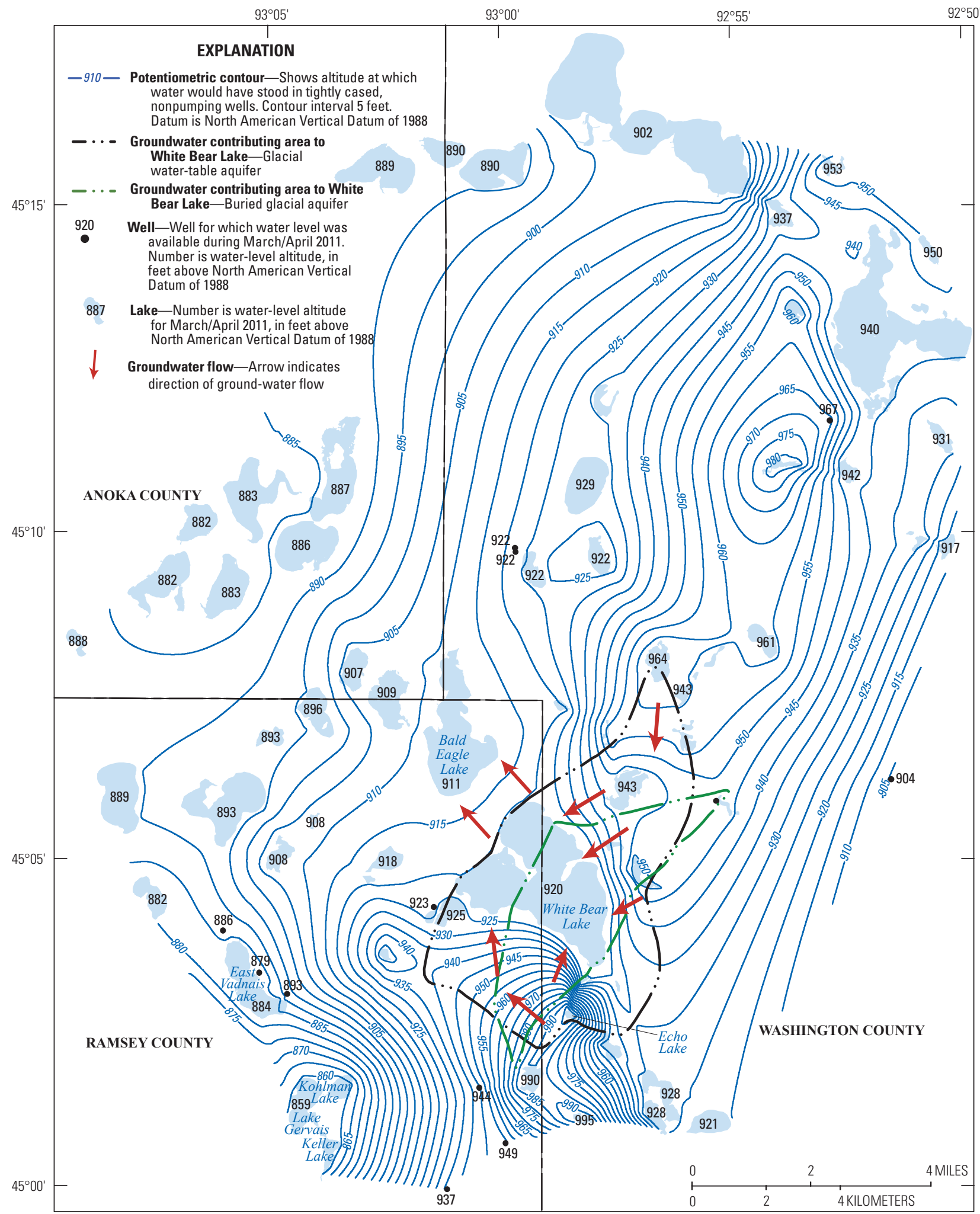

Base data from Minnesota Department of Natural Resources digital data, 1:24,000 and U.S. Geological Survey, 1:100,000

Universal Transverse Mercator projection, Zone 15

Horizontal coordinate information is referenced to

the North American Datum of 1983 (NAD 83)

Figure 10. Potentiometric surface of the glacial water-table aquifer and lake levels in the northeast Twin Cities Metropolitan Area, Minnesota, March/April 2011. 
(fig. 1). The largest rise in groundwater level (6.59 ft) was in the well near Silver Lake that had the highest groundwater level. The largest decline in groundwater level $(2.96 \mathrm{ft})$ was in a well 3.5 mi west of White Bear Lake.

\section{St. Peter Aquifer}

The potentiometric maps for the St. Peter aquifer were determined from groundwater levels measured in 50 and 49 wells in March/April and August 2011, respectively (tables 2, 1-5, and 1-6). Groundwater levels in the St. Peter aquifer around White Bear Lake are lower than the surfacewater elevation for White Bear Lake, except for a small part of the eastern lakeshore near Mahtomedi, Minnesota (fig. 1). Potentiometric contours for the St. Peter aquifer (not shown) indicated groundwater in the aquifer near White Bear Lake flows from the northeast near Sunset, Round, and Long Lakes to the southwest toward Goose Lake (fig. 1). Groundwater levels indicate groundwater from the St. Peter aquifer may potentially enter White Bear Lake from a small area of the eastern side of the lake, and lake water may flow into the St. Peter aquifer under the rest of the lake where the aquifer is present. The highest groundwater levels in the St. Peter aquifer for March/April (946.52 ft above NAVD 88) and August (949.06 ft above NAVD 88) were in the northeast part of the study area near Long Lake about 4 mi northeast of White Bear Lake (fig. 1). The lowest groundwater levels in this aquifer for March/April (859.07 ft above NAVD 88) and August (860.32 ft above NAVD 88 ) were in a well in the southeast part of the study area adjacent to Kohlman Lake (fig. 1).

Small rises or declines (less than $2 \mathrm{ft}$ ) were observed in the groundwater levels for the St. Peter aquifer throughout most of the study area between March/April and August 2011. Groundwater levels rose more than $2 \mathrm{ft}$ southeast of White Bear Lake; none of the water levels measured in wells completed in the St. Peter aquifer for the synoptic studies had a water-level decline of $2 \mathrm{ft}$ or more. A well near Centerville Lake (fig. 1), approximately $7 \mathrm{mi}$ northwest of White Bear Lake, had the largest decline (1.3 ft) between March/April and August 2011. The largest rise in groundwater level $(4.7 \mathrm{ft})$ was in a well near Long Lake about $1.5 \mathrm{mi}$ southeast of the White Bear Lake (fig. 1).

\section{Prairie du Chien-Jordan Aquifer}

The potentiometric maps for the Prairie du Chien-Jordan aquifer were determined from groundwater levels measured in 115 and 117 wells in March/April and August 2011, respectively (fig. 11; tables 2, 1-5, and 1-6). Water-level differences between the Prairie du Chien-Jordan aquifer and White Bear Lake (elevation of $920 \mathrm{ft}$ above NAVD 88 in March/ April 2011 as shown in figure 10) indicate groundwater from the Prairie du Chien-Jordan aquifer likely does not flow into White Bear Lake, but flows in the aquifer beneath the lake. Lake water may potentially flow downward into the Prairie du Chien-Jordan aquifer under the lake. The potentiometric map for the aquifer indicates groundwater levels in the Prairie du Chien-Jordan aquifer below White Bear Lake are approximately 0 to $19 \mathrm{ft}$ lower than surface-water levels in the lake (fig. 11). Near White Bear Lake, groundwater in this aquifer flows toward the lake from the east and northeast and flows away from the lake south and southwest (fig. 11) but does not flow into the lake. The highest groundwater levels in the Prairie du Chien-Jordan aquifer in March/April (952.38 ft above NAVD 88) and August (953.52 ft above NAVD 88) were in well 93 (fig. 5), about 7.5 mi northeast of White Bear Lake (fig. 11). From the areas with the highest groundwater levels, groundwater in the aquifer flows to the west, southwest, and southeast, with some flow going to the north and northeast where the aquifer ends (fig. 11). The lowest groundwater levels in this aquifer in March (832.68 ft above NAVD 88) and August (833.71 ft above NAVD 88) were in a municipal well in the southwestern part of the study area, approximately 0.5 mi west of Lake Gervais (fig. 11).

Groundwater levels between March/April and August 2011 declined more than $10 \mathrm{ft}$ in the Prairie du Chien-Jordan aquifer south of White Bear Lake and to the north in Hugo, Minnesota (fig. 12). Summer declines in groundwater levels in the Prairie du Chien-Jordan aquifer are common because the Prairie du Chien-Jordan aquifer is the most heavily used aquifer in the White Bear Lake area and the TCMA, especially in summer. The largest decline in groundwater level (11.8 ft) was in a municipal well about $2 \mathrm{mi}$ south of White Bear Lake (fig. 12). Groundwater levels rose as much as $3.1 \mathrm{ft}$ between March/April and August 2011 to the north, northeast, east, and southeast of White Bear Lake (fig. 12). The largest rise in groundwater level (3.9 ft) was in a well about $1 \mathrm{mi}$ south of White Bear Lake in the city of Pine Springs, Minnesota (fig. 12).

\section{Precipitation Effects on 2011 Groundwater Levels}

Higher than normal precipitation in July in the TCMA likely resulted in less of a decline in groundwater levels recorded between the synoptic studies in March/April and August 2011 than generally would be expected. Monthly total precipitation for a high-density precipitation station in Vadnais Heights, Minnesota (station no. 218477, fig. 1), approximately 4.3 miles west of White Bear Lake, for July 2011 was 8.17 in. The 30-year normal (1981-2010) monthly precipitation for the same precipitation station for July was 4.4 in. (National Climatic Data Center, 2013).

Groundwater levels in observation wells 124395 and 481807 (figs. 1 and 8), both open to the Prairie du ChienJordan aquifer, indicate the observed groundwater-level changes between March/April and August 2011 in the Prairie du Chien-Jordan aquifer (fig. 12) generally were less than the typical water-level change over this 5- to 6-month period. The water level in well 124395, approximately $5 \mathrm{mi}$ north-northeast of White Bear Lake, rose by $0.99 \mathrm{ft}$ from April through August of 2011 (fig. 8), although the water 


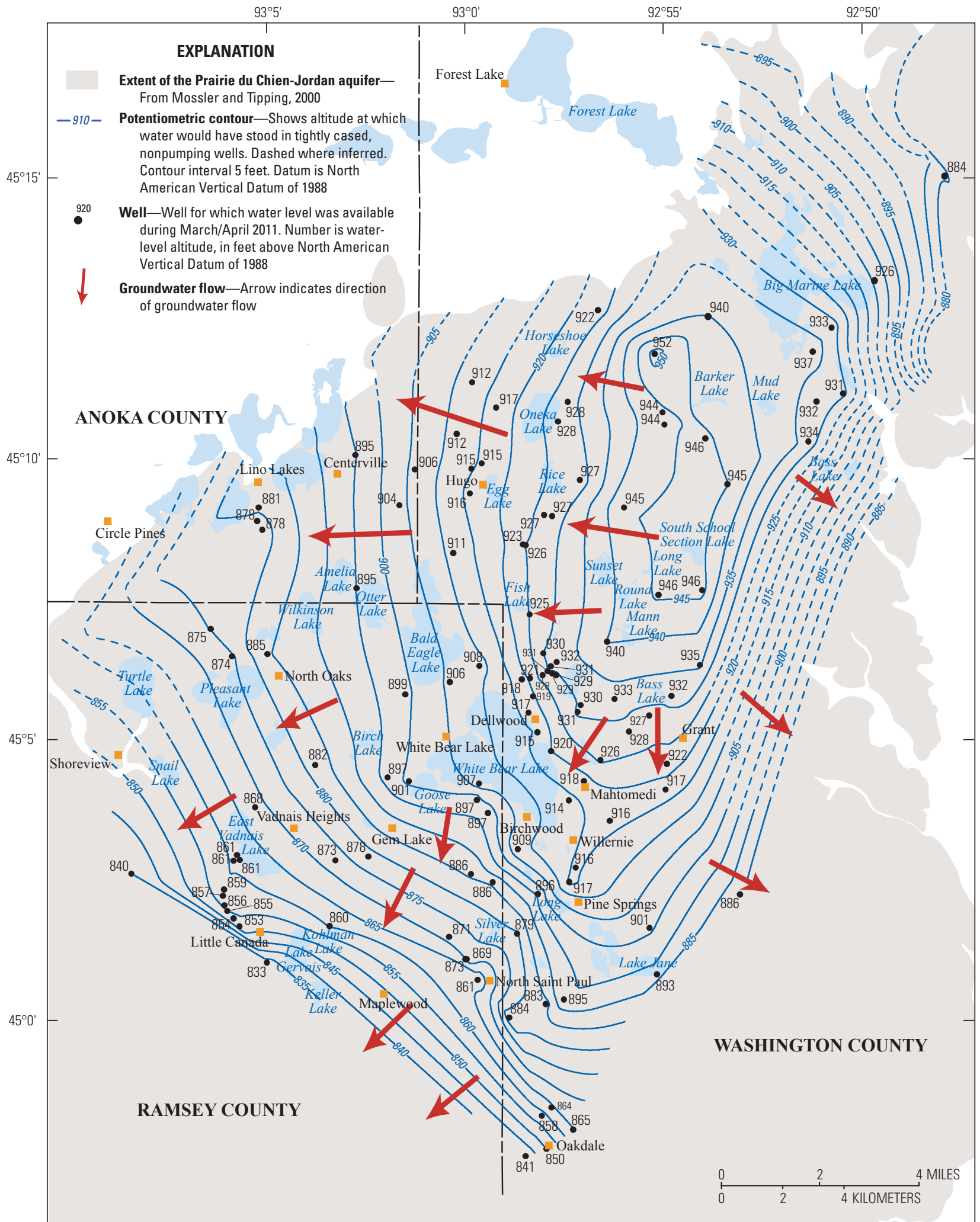

Base data from Minnesota Department of Natural Resources digital data, 1:24,000 and U.S. Geological Survey, 1:100,000

Universal Transverse Mercator projection, Zone 15

Horizontal coordinate information is referenced to the North American Datum of 1983 (NAD 83)

Figure 11. Potentiometric surface of the Prairie du Chien-Jordan aquifer in the northeast Twin Cities Metropolitan Area, Minnesota, March/April 2011. 


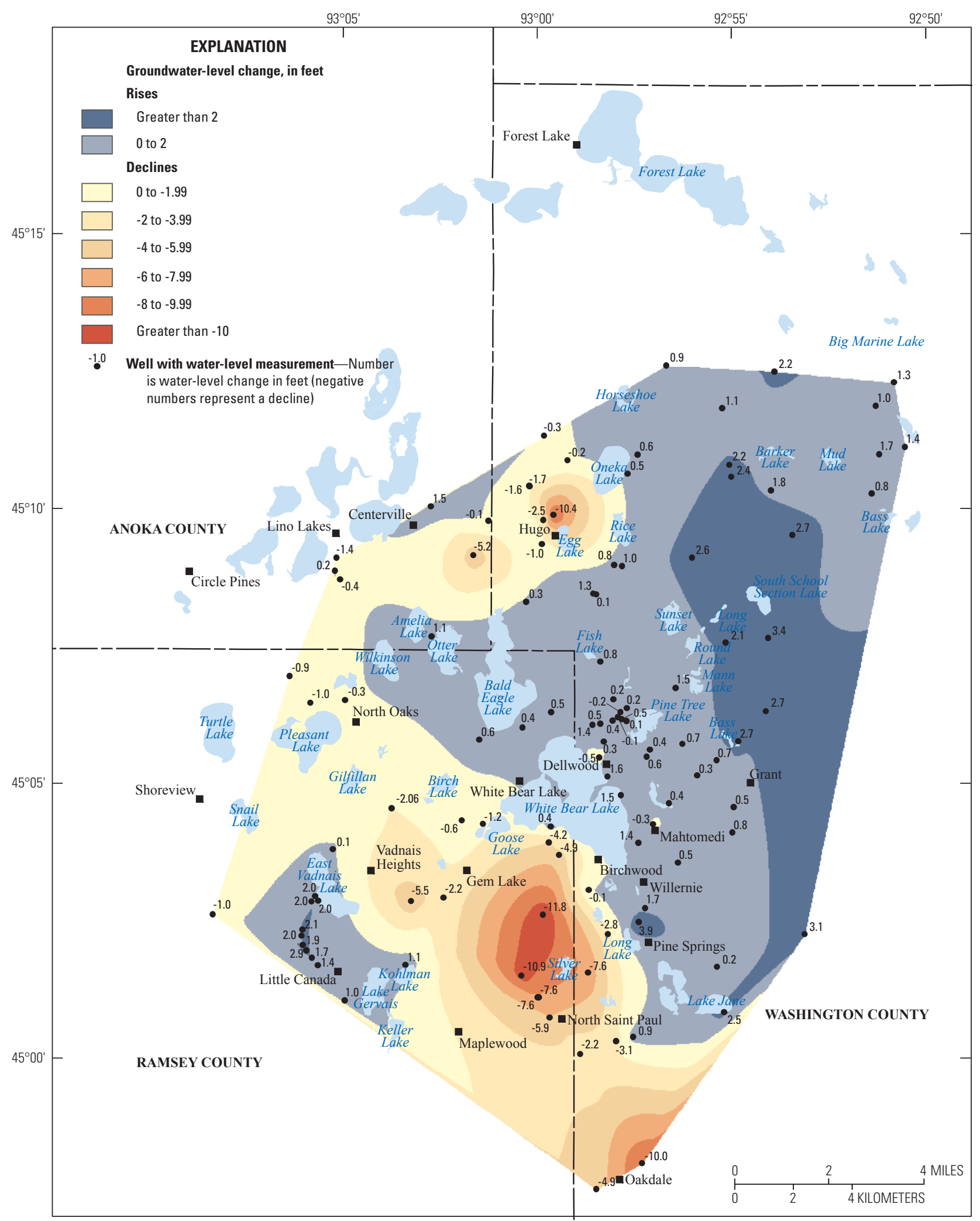

Base data from Minnesota Department of Natural Resources digital data, 1:24,000 and

U.S. Geological Survey, 1:100,000

Universal Transverse Mercator projection, Zone 15

Horizontal coordinate information is referenced to

the North American Datum of 1983 (NAD 83)

Figure 12. Groundwater-level changes in the Prairie du Chien-Jordan aquifer in the northeast Twin Cities Metropolitan Area, Minnesota, between March/April and August 2011. 
level typically declined during normal precipitation years. Similarly, the water-level decrease of $1.21 \mathrm{ft}$ from March/ April to August 2011 in well 481807, less than $1 \mathrm{mi}$ southwest of White Bear Lake (figs. 1 and 8), was less than two-thirds of observed decreases between March and August in previous years since 1992. Thus, the water-level changes between March/April and August 2011 shown in figure 12 probably were less than what would have taken place under normal precipitation conditions.

\section{Water Quality of White Bear Lake}

A total of 34 field samples were collected and analyzed for physical properties, major constituents, oxygen-18/oxygen-16 ratios, and deuterium/protium (hydrogen-2/hydrogen-1) ratios. These samples comprised 12 surface-water samples, 14 pore-water samples, and 8 well-water samples. With the exception of Bald Eagle Lake, all the lakes sampled for major constituents were either closed-basin lakes or have no major surface-water inlet. An additional 28 water samples were collected and analyzed for oxygen-18/oxygen-16 and deuterium/protium ratios: 4 snow samples, 3 precipitation samples, 13 surface-water samples, 1 porewater sample, and 7 well-water samples. The water-quality survey using the AUV was completed in the southeast, east, and northeast parts of White Bear Lake, covering approximately 43 percent of the total area of White Bear Lake. A total of 397 measurements were made in the lake-sediment temperature survey: 298 measurements in White Bear Lake, 59 measurements in Bald Eagle Lake, and 40 measurements in Goose Lake.

\section{Quality Assurance}

The percentage differences between environmental and replicate samples for concentrations of major constituents and stable isotope ratios indicated little variability resulting from sample collection, processing, shipping, and laboratory procedures performed at different sampling times. The percentage differences between environmental and replicate samples for concentrations of major constituents and stable isotope ratios were less than \pm 5 percent for all the constituents except for concentrations of dissolved manganese and iron in one surfacewater environmental/replicate sample set collected from White Bear Lake on July 29, 2011 (table 7). For this sample, the percentage differences for concentrations of dissolved manganese and iron were 24 and 20, respectively (table 7). The concentrations of dissolved manganese and iron in this environmental/ replicate sample set were less than 10 micrograms per liter $(\mu \mathrm{g} / \mathrm{L})$, and the dissolved iron concentration for the environmental sample was an estimated concentration, less than the laboratory reporting level and greater than the long-term method detection level (Childress and others, 1999). At these low concentrations, small changes in concentrations can result in large percentage differences. Hem (1985) stated that for constituent concentrations greater than 100 milligrams per liter $(\mathrm{mg} / \mathrm{L})$, percentage differences should be less than \pm 5 percent; for concentrations less than $1 \mathrm{mg} / \mathrm{L}$, percentage differences generally are not less than \pm 10 percent and can be higher.

Concentrations in the equipment blank sample for the mini-piezometer were greater than the laboratory reporting levels only for dissolved calcium, dissolved manganese, and dissolved barium (table 7), indicating the magnitude of contaminant concentration introduced into the sample as a result of using the sample-collection and processing equipment was low. Dissolved calcium concentration in the blank sample $(0.05 \mathrm{mg} / \mathrm{L})$ was less than two orders of magnitude lower than concentrations measured in all the pore-water samples (table 8). The concentrations of dissolved manganese and dissolved barium in the blank sample $(0.4$ and $0.6 \mu \mathrm{g} / \mathrm{L}$, respectively) were at or slightly greater than the laboratory reporting levels of 0.32 and 0.6 , respectively. Concentrations of dissolved manganese and dissolved barium in all the pore-water samples (table 8) were more than one order of magnitude higher than the concentrations in the blank sample (table 7).

\section{Precipitation}

All the oxygen-18/oxygen-16 and deuterium/protium ratios for the snow and bulk precipitation samples plot relatively close to a meteoric waterline determined by Landon and others (2000) for precipitation in Princeton, Minnesota (fig. 13A). Because most of the ratios are relatively close to this meteoric waterline, the meteoric waterline was used to assess the oxygen and hydrogen isotopes for the surfacewater, pore-water, and groundwater samples. Oxygen-18/ oxygen-16 ratios for snow samples collected at the four shoreline sites around White Bear Lake ranged from -21.9 to -18.5 per mil (fig. $13 \mathrm{~A}$; table 9 ); deuterium/protium ratios ranged from -162 to -137 per mil. Oxygen-18/oxygen-16 ratios for bulk precipitation samples collected at the precipitation station along the east shore of White Bear Lake ranged from -8.6 to -6.1 per mil (fig. $13 A$; table 9), and the deuterium/protium ratios ranged from -52.0 to -36.5 per mil.

\section{Surface-Water Quality}

Surface-water quality was evaluated by using an AUV survey, lake-sediment temperature surveys, and major constituents and stable isotopes. The surface-water-quality data collected as part of this study were used to evaluate groundwater/surface-water interactions. 
Table 7. Summary of quality-assurance data for sequential replicate samples and equipment blank samples collected at or near White Bear Lake, northeast Twin Cities Metropolitan Area, Minnesota, July through October 2011.

[Values in parentheses are percentage differences between concentrations in environmental samples and replicate samples; mg/L, milligrams per liter; $\mu \mathrm{g} / \mathrm{L}$, micrograms per liter; ${ }^{\circ} \mathrm{C}$, degrees $\mathrm{Celsius;}<$, less than; --, no data]

\begin{tabular}{|c|c|c|c|c|c|c|c|}
\hline Constituent & 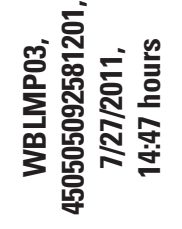 & 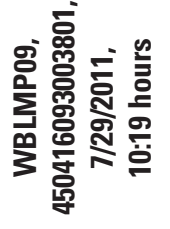 & 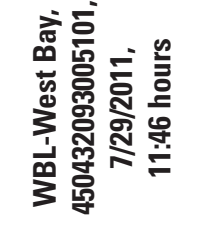 & 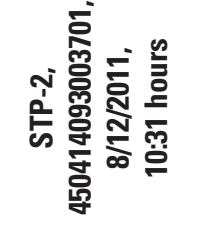 & 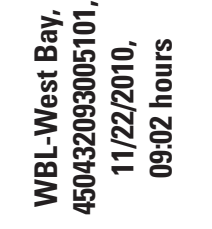 & 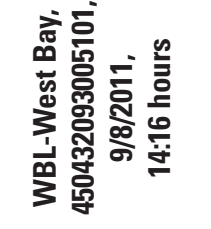 & 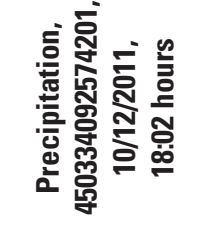 \\
\hline Sample type & $\begin{array}{c}\text { Pore-water } \\
\text { replicate }\end{array}$ & $\begin{array}{c}\text { Equipment } \\
\text { blank }\end{array}$ & $\begin{array}{l}\text { Surface-water } \\
\text { replicate }\end{array}$ & $\begin{array}{l}\text { Groundwater } \\
\text { replicate }\end{array}$ & $\begin{array}{l}\text { Surface-water } \\
\text { replicate }\end{array}$ & $\begin{array}{l}\text { Surface-water } \\
\text { replicate }\end{array}$ & $\begin{array}{c}\text { Bulk precipita- } \\
\text { tion replicate }\end{array}$ \\
\hline Hardness, water (mg/L) & $447(0.2)$ & $<0.17$ & $82(0.3)$ & $409(1.1)$ & -- & -- & -- \\
\hline Dissolved oxygen, water, unfiltered, percent of saturation & $9(0)$ & -- & $120(0)$ & -- & -- & -- & -- \\
\hline Dissolved calcium (mg/L) & $120(0)$ & 0.05 & $18(0.3)$ & $100(1.5)$ & -- & -- & -- \\
\hline Dissolved magnesium (mg/L) & $36(0.1)$ & $<0.008$ & $9.0(0.9)$ & $38(0.7)$ & -- & -- & -- \\
\hline Dissolved manganese $(\mu \mathrm{g} / \mathrm{L})$ & $1,060(0.5)$ & 0.4 & $2.3(24)$ & $62(0.4)$ & -- & -- & -- \\
\hline Dissolved sodium (mg/L) & $258(0.2)$ & $<0.06$ & $19(0.8)$ & $24(0.4)$ & -- & -- & -- \\
\hline Dissolved potassium (mg/L) & $3.4(0.4)$ & $<0.02$ & $1.2(1.2)$ & $1.85(0.3)$ & -- & -- & -- \\
\hline Bicarbonate, water, filtered, inflection-point titration (mg/L) & $322(0)$ & -- & $73(4.7)$ & $361(1.9)$ & -- & -- & -- \\
\hline Carbon dioxide, water, unfiltered (mg/L) & $217(3.6)$ & -- & $0.1(0)$ & $53(4.5)$ & -- & -- & -- \\
\hline Carbonate, water, filtered, inflection-point titration (mg/L) & $0.1(0)$ & -- & $3.1(1.6)$ & $0.2(0)$ & -- & -- & -- \\
\hline Alkalinity, water, filtered, fixed endpoint ( $\mathrm{pH} 4.5$ ) titration (mg/L) & -- & -- & $73(0.7)$ & $282(4.4)$ & -- & -- & -- \\
\hline Alkalinity, water, filtered, inflection-point titration $(\mathrm{mg} / \mathrm{L})$ & $264(0)$ & -- & $65(4.5)$ & $296(2.0)$ & -- & -- & -- \\
\hline Dissolved sulfate (mg/L) & $44(0.5)$ & $<0.09$ & $3.9(0.1)$ & $43(0.5)$ & -- & -- & -- \\
\hline Dissolved chloride (mg/L) & $551(0.1)$ & $<0.06$ & $36(0.1)$ & $71(0.1)$ & -- & -- & -- \\
\hline Dissolved silica (mg/L) & $31(0)$ & $<0.03$ & $3.0(1.7)$ & $23(0.9)$ & -- & -- & -- \\
\hline Dissolved iron $(\mu \mathrm{g} / \mathrm{L})$ & $21,800(0.2)$ & $<3$ & $9(20)$ & $78(1.3)$ & -- & -- & -- \\
\hline Dissolved barium $(\mu \mathrm{g} / \mathrm{L})$ & $228(0.4)$ & 0.6 & $34(0.3)$ & $32(1.1)$ & -- & -- & -- \\
\hline Dissolved strontium $(\mu \mathrm{g} / \mathrm{L})$ & $209(0.2)$ & $<0.2$ & $48(0.2)$ & $127(0.8)$ & -- & -- & -- \\
\hline Dissolved solids dried at $180^{\circ} \mathrm{C}$, water $(\mathrm{mg} / \mathrm{L})$ & $1,320(0.4)$ & $<12$ & $162(3.9)$ & $533(0.1)$ & -- & -- & -- \\
\hline Oxygen-18/oxygen-16 ratio, unfiltered water, per mil & $-10.62(-0.1)$ & -- & $-2.34(-2.1)$ & $-8.49(-0.3)$ & $-2.16(-1.4)$ & $-2.18(-0.5)$ & $-50.8(-0.2)$ \\
\hline Deuterium/protium ratio, unfiltered water, per mil & $-76.4(-0.2)$ & -- & $-28.3(-0.9)$ & $-59.3(-1.3)$ & $-27.7(-0.2)$ & $-26.6(-1.7)$ & $-8.64(0)$ \\
\hline
\end{tabular}


Table 8. Water-quality data for lake water, groundwater, and pore water collected at or near White Bear Lake, northeast Twin Cities Metropolitan Area, Minnesota, July through September 2011.

[mm, millimeters; $\mathrm{Hg}$, mercury; $\mu \mathrm{S} / \mathrm{cm}$ at $25^{\circ} \mathrm{C}$, microsiemens per centimeter at 25 degrees Celsius; ${ }^{\circ} \mathrm{C}$, degrees Celsius; mg/L, milligrams per liter; $\mu \mathrm{g} / \mathrm{L}$, micrograms per liter; $<$, less than; E, estimated; $\mathrm{M}$, presence verified but not quantified; --, no data]

\begin{tabular}{|c|c|c|c|c|c|c|c|c|c|c|c|}
\hline $\begin{array}{l}\text { Water-quality } \\
\text { sampling site }\end{array}$ & Site number & $\begin{array}{c}\text { Date } \\
\text { (month/day/ } \\
\text { year) }\end{array}$ & $\begin{array}{c}\text { Time } \\
\text { (24-hour) }\end{array}$ & $\begin{array}{c}\text { Sample } \\
\text { type }\end{array}$ & $\begin{array}{l}\text { Barometric } \\
\text { pressure, on } \\
\text { site }(\mathrm{mm} \mathrm{Hg})\end{array}$ & $\begin{array}{c}\text { Specific } \\
\text { conductance, } \\
\text { on site } \\
(\mu \mathrm{S} / \mathrm{cm} \text { at } \\
\left.25^{\circ} \mathrm{C}\right)\end{array}$ & $\begin{array}{c}\text { Specific } \\
\text { conductance, } \\
\text { laboratory } \\
(\mu \mathrm{S} / \mathrm{cm} \text { at } \\
\left.25^{\circ} \mathrm{C}\right)\end{array}$ & $\begin{array}{c}\text { pH, } \\
\text { on site } \\
\text { (standard } \\
\text { units) }\end{array}$ & $\begin{array}{c}\text { pH, } \\
\text { laboratory } \\
\text { (standard } \\
\text { units) }\end{array}$ & $\begin{array}{c}\text { Air } \\
\text { temperature } \\
\left({ }^{\circ} \mathrm{C}\right)\end{array}$ & $\begin{array}{c}\text { Water } \\
\text { temperature } \\
\left({ }^{\circ} \mathrm{C}\right)\end{array}$ \\
\hline Bald Eagle Lake & 450650093000801 & $8 / 3 / 2011$ & 1030 & Lake & 739 & 404 & 386 & 8.0 & 8.3 & 23 & 25.2 \\
\hline Birch Lake & 450456093020801 & $8 / 3 / 2011$ & 0945 & Lake & 739 & 362 & 352 & 7.5 & 7.3 & 18 & 25.2 \\
\hline Echo Lake & 450512092574901 & $8 / 3 / 2011$ & 1600 & Lake & 739 & 76 & E76 & 6.3 & E6.6 & 29 & 28.0 \\
\hline Goose Lake & 450424093005701 & $7 / 29 / 2011$ & 1330 & Lake & 740 & 368 & 361 & 9.5 & 9.8 & -- & 27.6 \\
\hline Long Lake & 450437092564101 & $8 / 3 / 2011$ & 1645 & Lake & 739 & 246 & 240 & 7.1 & 7.3 & 28.5 & 33.0 \\
\hline Lost Lake & 450306092575901 & $8 / 3 / 2011$ & 1730 & Lake & 739 & 311 & 303 & 7.0 & 7.4 & -- & 25.7 \\
\hline Mann Lake & 450641092554601 & $8 / 3 / 2011$ & 1345 & Lake & 739 & 125 & 125 & 7.8 & 7.3 & 28.5 & 28.7 \\
\hline Pine Tree Lake & 450618092572001 & $8 / 3 / 2011$ & 1215 & Lake & 739 & 134 & 132 & 9.3 & 9.0 & 26 & 27.4 \\
\hline Sunset Lake & 450743092563101 & $8 / 3 / 2011$ & 1445 & Lake & 739 & 181 & 172 & 9.2 & 9.2 & 28.5 & 29.4 \\
\hline Turtle Lake & 450534093075101 & $8 / 3 / 2011$ & 0845 & Lake & 739 & 321 & 313 & 8.4 & 8.3 & 18 & 25.0 \\
\hline WBL-Mahtomedi Beach & 450410092574101 & $7 / 26 / 2011$ & 1430 & Lake & 732 & 291 & 291 & 8.9 & 8.8 & -- & 28.1 \\
\hline WBL-West Bay & 450432093005101 & $7 / 29 / 2011$ & 1145 & Lake & 740 & 265 & 262 & 9.2 & 9.0 & -- & 27.3 \\
\hline WBLMP01 & 450409092574101 & $7 / 26 / 2011$ & 1400 & Pore water & 732 & 910 & 892 & 6.3 & 6.7 & -- & 19.2 \\
\hline WBLMP02 & 450453092575501 & $7 / 27 / 2011$ & 1300 & Pore water & 732 & 480 & 407 & 6.7 & 6.9 & -- & 17.1 \\
\hline WBLMP03 & 450505092581201 & $7 / 27 / 2011$ & 1445 & Pore water & 739 & 2,220 & 2,120 & 6.3 & 6.8 & -- & 20.3 \\
\hline WBLMP04 & 450526092583701 & $7 / 28 / 2011$ & 0945 & Pore water & 737 & 1,120 & 1,100 & 6.9 & 7.3 & -- & 18.2 \\
\hline WBLMP05 & 450544092590201 & $7 / 28 / 2011$ & 1145 & Pore water & 737 & 1,120 & 959 & 6.9 & 7.1 & -- & 22.2 \\
\hline WBLMP07 & 450401092574401 & $7 / 28 / 2011$ & 1440 & Pore water & 737 & 915 & 916 & 6.2 & 6.7 & -- & 18.6 \\
\hline WBLMP08 & 450426093005001 & $7 / 28 / 2011$ & 1645 & Pore water & 737 & 424 & 416 & 6.7 & 7.3 & -- & 14.9 \\
\hline WBLMP09 & 450416093003801 & $7 / 29 / 2011$ & 1020 & Pore water & 740 & 760 & 730 & 6.6 & 7.0 & -- & 17.4 \\
\hline WBLMP11 & 450517092595701 & $8 / 24 / 2011$ & 1545 & Pore water & 732 & 890 & 877 & 7.0 & 7.3 & -- & 25.2 \\
\hline WBLMP12 & 450322092575701 & $8 / 25 / 2011$ & 1340 & Pore water & 739 & 662 & 636 & 6.7 & 7.0 & -- & 18.6 \\
\hline GLMP13 & 450422093005101 & $8 / 30 / 2011$ & 1430 & Pore water & 737 & 650 & 613 & 7.8 & 7.4 & -- & 23.4 \\
\hline GLMP14 & 450410093004201 & $8 / 31 / 2011$ & 1330 & Pore water & 736 & 397 & 360 & 7.7 & 7.3 & -- & 23.4 \\
\hline BELMP15 & 450649093000501 & $8 / 31 / 2011$ & 1540 & Pore water & 736 & 1,920 & 1,630 & 6.6 & 6.9 & -- & 22.9 \\
\hline BELMP16 & 450603093004201 & 9/1/2011 & 1020 & Pore water & 733 & 916 & 807 & 6.9 & 7.2 & -- & 23.4 \\
\hline GLA-1 & 450546093002401 & 8/9/2011 & 1220 & Well water & 732 & 928 & 953 & 7.4 & 8.1 & -- & 11.5 \\
\hline GLA-2 & 450459092593001 & $8 / 9 / 2011$ & 1400 & Well water & 732 & 444 & 428 & 7.2 & 7.9 & -- & 11.2 \\
\hline GLA-3 & 450542093001501 & $8 / 9 / 2011$ & 1605 & Well water & 732 & 594 & 605 & 7.6 & 8.1 & -- & 10.5 \\
\hline GLA-4 & 450412092594002 & $8 / 23 / 2011$ & 1345 & Well water & 732 & 473 & 453 & 6.6 & 6.9 & -- & 10.9 \\
\hline STP-2 & 450414093003701 & $8 / 12 / 2011$ & 1030 & Well water & 735 & 898 & 915 & 7.0 & 7.4 & -- & 11.5 \\
\hline STP-1 & 450451092574201 & $8 / 12 / 2011$ & 1300 & Well water & 735 & 453 & 456 & 7.5 & 7.7 & -- & 9.7 \\
\hline PDC-1 & 450508092580901 & $8 / 22 / 2011$ & 1645 & Well water & 740 & 460 & 465 & 7.8 & 7.7 & -- & 9.9 \\
\hline PDC-2 & 450412092594001 & $8 / 30 / 2011$ & 1300 & Well water & 737 & 353 & 345 & 7.4 & 7.8 & -- & 11.8 \\
\hline
\end{tabular}


Table 8. Water-quality data for lake water, groundwater, and pore water collected at or near White Bear Lake, northeast Twin Cities Metropolitan Area, Minnesota, July through September 2011.-Continued

[mm, millimeters; $\mathrm{Hg}$, mercury; $\mu \mathrm{S} / \mathrm{cm}$ at $25{ }^{\circ} \mathrm{C}$, microsiemens per centimeter at 25 degrees Celsius; ${ }^{\circ} \mathrm{C}$, degrees Celsius; $\mathrm{mg} / \mathrm{L}$, milligrams per liter; $\mu \mathrm{g} / \mathrm{L}$, micrograms per liter; <, less than; E, estimated; $\mathrm{M}$, presence verified but not quantified; --, no data]

\begin{tabular}{|c|c|c|c|c|c|c|c|c|c|c|c|}
\hline $\begin{array}{l}\text { Water-quality } \\
\text { sampling site }\end{array}$ & Site number & $\begin{array}{c}\text { Date } \\
\text { (month/day/ } \\
\text { year) }\end{array}$ & $\begin{array}{c}\text { Time } \\
\text { (24-hour) }\end{array}$ & $\begin{array}{l}\text { Sample } \\
\text { type }\end{array}$ & $\begin{array}{c}\text { Hardness, } \\
\text { water } \\
\text { (mg/L) }\end{array}$ & $\begin{array}{l}\text { Dissolved } \\
\text { oxygen, } \\
\text { on site } \\
\text { (mg/L) }\end{array}$ & $\begin{array}{l}\text { Dissolved oxygen, } \\
\text { water, unfiltered, } \\
\text { percent of } \\
\text { saturation }\end{array}$ & $\begin{array}{l}\text { Dissolved } \\
\text { calcium } \\
\text { (mg/L) }\end{array}$ & $\begin{array}{c}\text { Dissolved } \\
\text { magnesium } \\
(\mathrm{mg} / \mathrm{L})\end{array}$ & $\begin{array}{c}\text { Dissolved } \\
\text { manganese } \\
(\mu \mathrm{g} / \mathrm{L})\end{array}$ & $\begin{array}{l}\text { Dissolved } \\
\text { sodium } \\
\text { (mg/L) }\end{array}$ \\
\hline Bald Eagle Lake & 450650093000801 & $8 / 3 / 2011$ & 1030 & Lake & 146 & 5.0 & 63 & 36 & 13.7 & 2.1 & 21 \\
\hline Birch Lake & 450456093020801 & $8 / 3 / 2011$ & 0945 & Lake & 42 & 6.3 & 79 & 10 & 3.9 & 8 & 51 \\
\hline Echo Lake & 450512092574901 & $8 / 3 / 2011$ & 1600 & Lake & 14 & 3.9 & 51 & 3 & 1.7 & 20.3 & 7.6 \\
\hline Goose Lake & 450424093005701 & $7 / 29 / 2011$ & 1330 & Lake & 54 & 8.0 & 105 & 14 & 4.7 & 8 & 46 \\
\hline Long Lake & 450437092564101 & $8 / 3 / 2011$ & 1645 & Lake & 90 & 3.5 & 50 & 22 & 8.6 & 69.2 & 11 \\
\hline Lost Lake & 450306092575901 & $8 / 3 / 2011$ & 1730 & Lake & 82 & 3.0 & 38 & 21 & 6.9 & 13.1 & 28 \\
\hline Mann Lake & 450641092554601 & $8 / 3 / 2011$ & 1345 & Lake & 43 & 6.2 & 82 & 10 & 4.4 & 23.2 & 4.7 \\
\hline Pine Tree Lake & 450618092572001 & $8 / 3 / 2011$ & 1215 & Lake & 51 & 9.4 & 123 & 11 & 5.8 & 6.9 & 5.7 \\
\hline Sunset Lake & 450743092563101 & $8 / 3 / 2011$ & 1445 & Lake & 59 & 8.8 & 119 & 12 & 7 & 7.4 & 9.4 \\
\hline Turtle Lake & 450534093075101 & $8 / 3 / 2011$ & 0845 & Lake & 112 & 6.7 & 83 & 26 & 12 & 2.1 & 20 \\
\hline WBL-Mahtomedi Beach & 450410092574101 & $7 / 26 / 2011$ & 1430 & Lake & 96 & 9.8 & 131 & 23 & 9.4 & 1.9 & 20 \\
\hline WBL-West Bay & 450432093005101 & $7 / 29 / 2011$ & 1145 & Lake & 83 & 9.3 & 120 & 18 & 9.1 & 1.4 & 19 \\
\hline WBLMP01 & 450409092574101 & $7 / 26 / 2011$ & 1400 & Pore water & 192 & 0.9 & 11 & 47 & 18 & 43 & 100 \\
\hline WBLMP02 & 450453092575501 & $7 / 27 / 2011$ & 1300 & Pore water & 177 & 0.9 & 10 & 50 & 12 & 865 & 15 \\
\hline WBLMP03 & 450505092581201 & $7 / 27 / 2011$ & 1445 & Pore water & 445 & 0.8 & 9 & 120 & 36 & 1,050 & 257 \\
\hline WBLMP04 & 450526092583701 & $7 / 28 / 2011$ & 0945 & Pore water & 516 & 1.3 & 14 & 133 & 44 & 1,070 & 24 \\
\hline WBLMP05 & 450544092590201 & $7 / 28 / 2011$ & 1145 & Pore water & 415 & 1.0 & 12 & 106 & 36 & 241 & 48 \\
\hline WBLMP07 & 450401092574401 & $7 / 28 / 2011$ & 1440 & Pore water & 258 & 8.3 & 92 & 62 & 25 & 6.6 & 73 \\
\hline WBLMP08 & 450426093005001 & $7 / 28 / 2011$ & 1645 & Pore water & 62 & 1.2 & 12 & 18 & 4.1 & 156 & 68 \\
\hline WBLMP09 & 450416093003801 & $7 / 29 / 2011$ & 1020 & Pore water & 347 & 1.0 & 11 & 91 & 29 & 923 & 15 \\
\hline WBLMP11 & 450517092595701 & $8 / 24 / 2011$ & 1545 & Pore water & 425 & -- & -- & 121 & 30 & 958 & 17 \\
\hline WBLMP12 & 450322092575701 & $8 / 25 / 2011$ & 1340 & Pore water & 247 & 0.9 & -- & 59 & 24 & 728 & 29 \\
\hline GLMP13 & 450422093005101 & $8 / 30 / 2011$ & 1430 & Pore water & 156 & 0.9 & -- & 50 & 7.4 & 458 & 56 \\
\hline GLMP14 & 450410093004201 & $8 / 31 / 2011$ & 1330 & Pore water & 69 & 1.6 & -- & 20 & 4.2 & 131 & 42 \\
\hline BELMP15 & 450649093000501 & $8 / 31 / 2011$ & 1540 & Pore water & 483 & 3.5 & -- & 146 & 29 & 989 & 117 \\
\hline BELMP16 & 450603093004201 & 9/1/2011 & 1020 & Pore water & 289 & $\mathrm{E} 2.5$ & -- & 82 & 21 & 1,840 & 50 \\
\hline GLA-1 & 450546093002401 & $8 / 9 / 2011$ & 1220 & Well water & 418 & 0.1 & -- & 108 & 36 & 639 & 26 \\
\hline GLA-2 & 450459092593001 & $8 / 9 / 2011$ & 1400 & Well water & 186 & 0.1 & -- & 49 & 15 & 1,140 & 11 \\
\hline GLA-3 & 450542093001501 & 8/9/2011 & 1605 & Well water & 303 & 0.1 & -- & 74 & 28 & 605 & 6 \\
\hline GLA-4 & 450412092594002 & $8 / 23 / 2011$ & 1345 & Well water & 80 & 0.1 & -- & 18 & 8.4 & 342 & 58 \\
\hline STP-2 & 450414093003701 & $8 / 12 / 2011$ & 1030 & Well water & 418 & 2.2 & -- & 103 & 39 & 61.4 & 24 \\
\hline STP-1 & 450451092574201 & $8 / 12 / 2011$ & 1300 & Well water & 227 & 0.01 & -- & 55 & 22 & 871 & 4.6 \\
\hline PDC-1 & 450508092580901 & $8 / 22 / 2011$ & 1645 & Well water & 225 & 0.1 & -- & 58 & 20 & 411 & 6.3 \\
\hline PDC-2 & 450412092594001 & $8 / 30 / 2011$ & 1300 & Well water & 175 & E0.1 & -- & 43 & 16 & 158 & 5.5 \\
\hline
\end{tabular}


Table 8. Water-quality data for lake water, groundwater, and pore water collected at or near White Bear Lake, northeast Twin Cities Metropolitan Area, Minnesota, July through September 2011.-Continued

[mm, millimeters; $\mathrm{Hg}$, mercury; $\mu \mathrm{S} / \mathrm{cm}$ at $25^{\circ} \mathrm{C}$, microsiemens per centimeter at 25 degrees Celsius; ${ }^{\circ} \mathrm{C}$, degrees Celsius; mg/L, milligrams per liter; $\mu \mathrm{g} / \mathrm{L}$, micrograms per liter; $<$, less than; E, estimated; $\mathrm{M}$, presence verified but not quantified; --, no data]

\begin{tabular}{|c|c|c|c|c|c|c|c|c|c|c|c|}
\hline $\begin{array}{l}\text { Water-quality } \\
\text { sampling site }\end{array}$ & Site number & $\begin{array}{c}\text { Date } \\
\text { (month/day/ } \\
\text { year) }\end{array}$ & $\begin{array}{c}\text { Time } \\
\text { (24-hour) }\end{array}$ & $\begin{array}{c}\text { Sample } \\
\text { type }\end{array}$ & $\begin{array}{c}\text { Dissolved } \\
\text { potassium } \\
\text { (mg/L) }\end{array}$ & $\begin{array}{l}\text { Bicarbonate, } \\
\text { water, filtered, } \\
\text { inflection-point } \\
\text { titration } \\
\text { (mg/L) }\end{array}$ & $\begin{array}{l}\text { Carbon } \\
\text { dioxide, } \\
\text { water, } \\
\text { unfiltered } \\
\text { (mg/L) }\end{array}$ & $\begin{array}{c}\text { Carbonate, } \\
\text { water, } \\
\text { filtered, } \\
\text { inflection- } \\
\text { point titration } \\
\text { (mg/L) }\end{array}$ & $\begin{array}{l}\text { Alkalinity, } \\
\text { water, } \\
\text { filtered, } \\
\text { inflection- } \\
\text { point titration } \\
\text { (mg/L) }\end{array}$ & $\begin{array}{c}\text { Alkalinity, } \\
\text { water, filtered, } \\
\text { fixed endpoint } \\
\text { (pH 4.5) } \\
\text { titration } \\
\text { (mg/L) }\end{array}$ & $\begin{array}{l}\text { Dissolved } \\
\text { sulfate } \\
\text { (mg/L) }\end{array}$ \\
\hline Bald Eagle Lake & 450650093000801 & $8 / 3 / 2011$ & 1030 & Lake & 2.8 & 142 & 2.3 & 3.2 & 122 & 124 & 5.1 \\
\hline Birch Lake & 450456093020801 & $8 / 3 / 2011$ & 0945 & Lake & 1.7 & 35 & 2 & -- & 29 & 30 & 5.5 \\
\hline Echo Lake & 450512092574901 & $8 / 3 / 2011$ & 1600 & Lake & 0.8 & 5.8 & 4.6 & -- & 5 & 9 & 2.6 \\
\hline Goose Lake & 450424093005701 & $7 / 29 / 2011$ & 1330 & Lake & 1.8 & 38.8 & $\mathrm{M}$ & 8.3 & 48 & 55 & 1.4 \\
\hline Long Lake & 450437092564101 & 8/3/2011 & 1645 & Lake & 1.5 & 87.9 & 11 & 0.1 & 72 & 71 & 1.5 \\
\hline Lost Lake & 450306092575901 & $8 / 3 / 2011$ & 1730 & Lake & 1.3 & 78 & 12 & 0.1 & 64 & 68 & 1.7 \\
\hline Mann Lake & 450641092554601 & $8 / 3 / 2011$ & 1345 & Lake & 3.1 & 30.1 & 0.8 & -- & 25 & 35 & 1.4 \\
\hline Pine Tree Lake & 450618092572001 & $8 / 3 / 2011$ & 1215 & Lake & 1.6 & 40 & $\mathrm{M}$ & 3.7 & 40 & 43 & 0.53 \\
\hline Sunset Lake & 450743092563101 & $8 / 3 / 2011$ & 1445 & Lake & 1.3 & -- & 0.1 & -- & -- & 46 & 0.4 \\
\hline Turtle Lake & 450534093075101 & $8 / 3 / 2011$ & 0845 & Lake & 1.2 & 111 & 0.7 & 0.7 & 93 & 87 & 7.8 \\
\hline WBL-Mahtomedi Beach & 450410092574101 & $7 / 26 / 2011$ & 1430 & Lake & 1.6 & 91.6 & 0.2 & 5.8 & 86 & -- & 3.9 \\
\hline WBL-West Bay & 450432093005101 & $7 / 29 / 2011$ & 1145 & Lake & 1.2 & 79.9 & 0.1 & 3.2 & 71 & 74 & 3.9 \\
\hline WBLMP01 & 450409092574101 & $7 / 26 / 2011$ & 1400 & Pore water & 3.5 & 176 & 139 & -- & 144 & -- & 16 \\
\hline WBLMP02 & 450453092575501 & $7 / 27 / 2011$ & 1300 & Pore water & 2.1 & 230 & 83 & 0.1 & 189 & -- & 4.3 \\
\hline WBLMP03 & 450505092581201 & $7 / 27 / 2011$ & 1445 & Pore water & 3.4 & 322 & 233 & 0.1 & 264 & -- & 43 \\
\hline WBLMP04 & 450526092583701 & $7 / 28 / 2011$ & 0945 & Pore water & 3.3 & 415 & 87 & 0.2 & 341 & -- & 43 \\
\hline WBLMP05 & 450544092590201 & $7 / 28 / 2011$ & 1145 & Pore water & 1.9 & 479 & 89 & 0.2 & 393 & -- & 56 \\
\hline WBLMP07 & 450401092574401 & $7 / 28 / 2011$ & 1440 & Pore water & 2.4 & 123 & 114 & -- & 101 & -- & 22 \\
\hline WBLMP08 & 450426093005001 & $7 / 28 / 2011$ & 1645 & Pore water & 2.1 & 222 & 65 & 0.1 & 182 & -- & 24 \\
\hline WBLMP09 & 450416093003801 & $7 / 29 / 2011$ & 1020 & Pore water & 3.4 & 429 & 167 & 0.1 & 352 & 353 & 25 \\
\hline WBLMP11 & 450517092595701 & $8 / 24 / 2011$ & 1545 & Pore water & 2.2 & 339 & 50 & 0.4 & 279 & -- & 119 \\
\hline WBLMP12 & 450322092575701 & $8 / 25 / 2011$ & 1340 & Pore water & 3.8 & 274 & 84 & 0.1 & 224 & -- & 1.3 \\
\hline GLMP13 & 450422093005101 & $8 / 30 / 2011$ & 1430 & Pore water & 6.2 & 219 & 5.1 & 0.6 & 181 & -- & 0.71 \\
\hline GLMP14 & 450410093004201 & $8 / 31 / 2011$ & 1330 & Pore water & 2.3 & 88.7 & 3 & 0.1 & 73 & -- & 1.2 \\
\hline BELMP15 & 450649093000501 & $8 / 31 / 2011$ & 1540 & Pore water & 4.2 & 416 & 173 & 0.2 & 342 & -- & $<1.8$ \\
\hline BELMP16 & 450603093004201 & 9/1/2011 & 1020 & Pore water & 9.3 & 424 & 86 & 0.2 & 348 & -- & $<0.09$ \\
\hline GLA-1 & 450546093002401 & $8 / 9 / 2011$ & 1220 & Well water & 2.5 & 366 & 22 & 0.6 & 301 & 302 & 31 \\
\hline GLA-2 & 450459092593001 & $8 / 9 / 2011$ & 1400 & Well water & 2.4 & 219 & 25 & 0.1 & 180 & 176 & 3.9 \\
\hline GLA-3 & 450542093001501 & 8/9/2011 & 1605 & Well water & 2.3 & 316 & 12 & 0.9 & 261 & 268 & 3 \\
\hline GLA-4 & 450412092594002 & $8 / 23 / 2011$ & 1345 & Well water & 5.4 & 140 & 58 & 0.1 & 115 & -- & 15 \\
\hline STP-2 & 450414093003701 & $8 / 12 / 2011$ & 1030 & Well water & 1.8 & 375 & 58 & 0.2 & 308 & 308 & 43 \\
\hline STP-1 & 450451092574201 & $8 / 12 / 2011$ & 1300 & Well water & 1.4 & 277 & 13 & 0.4 & 227 & 229 & 0.83 \\
\hline PDC-1 & 450508092580901 & $8 / 22 / 2011$ & 1645 & Well water & 1.9 & 263 & 7.6 & 0.3 & 216 & -- & 8.1 \\
\hline PDC-2 & 450412092594001 & $8 / 30 / 2011$ & 1300 & Well water & 2.5 & 220 & 13 & 0.2 & 181 & -- & 3.3 \\
\hline
\end{tabular}


Table 8. Water-quality data for lake water, groundwater, and pore water collected at or near White Bear Lake, northeast Twin Cities Metropolitan Area, Minnesota, July through September 2011.-Continued

[mm, millimeters; Hg, mercury; $\mu \mathrm{S} / \mathrm{cm}$ at $25^{\circ} \mathrm{C}$, microsiemens per centimeter at 25 degrees Celsius; ${ }^{\circ} \mathrm{C}$, degrees Celsius; mg/L, milligrams per liter; $\mu \mathrm{g} / \mathrm{L}$, micrograms per liter; <, less than; $\mathrm{E}$, estimated; $\mathrm{M}$, presence verified but not quantified; --, no data]

\begin{tabular}{|c|c|c|c|c|c|c|c|c|c|c|c|}
\hline $\begin{array}{l}\text { Water-quality } \\
\text { sampling site }\end{array}$ & Site number & $\begin{array}{c}\text { Date } \\
\text { (month/day/ } \\
\text { year) }\end{array}$ & $\begin{array}{c}\text { Time } \\
\text { (24-hour) }\end{array}$ & $\begin{array}{c}\text { Sample } \\
\text { type }\end{array}$ & $\begin{array}{l}\text { Dissolved } \\
\text { chloride } \\
\text { (mg/L) }\end{array}$ & $\begin{array}{l}\text { Dissolved } \\
\text { silica } \\
\text { (mg/L) }\end{array}$ & $\begin{array}{c}\text { Dissolved } \\
\text { iron } \\
(\mu \mathrm{g} / \mathrm{L})\end{array}$ & $\begin{array}{c}\text { Dissolved } \\
\text { barium } \\
\text { ( } \mu \mathrm{g} / \mathrm{L})\end{array}$ & $\begin{array}{l}\text { Dissolved } \\
\text { strontium } \\
(\mu \mathrm{g} / \mathrm{L})\end{array}$ & $\begin{array}{c}\text { Dissolved } \\
\text { solids dried at } \\
180^{\circ} \mathrm{C} \text {, water } \\
\text { (mg/L) }\end{array}$ & $\begin{array}{c}\text { Ionic balance } \\
\text { (percent } \\
\text { difference) }{ }^{2}\end{array}$ \\
\hline Bald Eagle Lake & 450650093000801 & $8 / 3 / 2011$ & 1030 & Lake & 42 & 11 & 5 & 50 & 78 & 238 & 2.4 \\
\hline Birch Lake & 450456093020801 & $8 / 3 / 2011$ & 0945 & Lake & 84 & 0.74 & 56 & 21 & 29 & 244 & 0.7 \\
\hline Echo Lake & 450512092574901 & 8/3/2011 & 1600 & Lake & 15 & 0.38 & 230 & 11 & 11 & 57 & 6.2 \\
\hline Goose Lake & 450424093005701 & $7 / 29 / 2011$ & 1330 & Lake & 75 & 3 & 94 & 25 & 32 & 210 & 0.5 \\
\hline Long Lake & 450437092564101 & $8 / 3 / 2011$ & 1645 & Lake & 26 & 4.1 & 257 & 31 & 51 & 137 & 2.2 \\
\hline Lost Lake & 450306092575901 & $8 / 3 / 2011$ & 1730 & Lake & 49 & 2.2 & 208 & 23 & 51 & 176 & 2.8 \\
\hline Mann Lake & 450641092554601 & $8 / 3 / 2011$ & 1345 & Lake & 14 & 1.4 & 28 & 20 & 24 & 77 & 11 \\
\hline Pine Tree Lake & 450618092572001 & $8 / 3 / 2011$ & 1215 & Lake & 13 & 0.8 & 48 & 16 & 28 & 82 & 5.5 \\
\hline Sunset Lake & 450743092563101 & $8 / 3 / 2011$ & 1445 & Lake & 23 & 0.58 & 42 & 11 & 27 & 105 & 1.9 \\
\hline Turtle Lake & 450534093075101 & $8 / 3 / 2011$ & 0845 & Lake & 38 & 2.8 & $<3$ & 50 & 77 & 176 & 0.8 \\
\hline WBL-Mahtomedi Beach & 450410092574101 & $7 / 26 / 2011$ & 1430 & Lake & 37 & 2 & 7 & 38 & 54 & 159 & 0.1 \\
\hline WBL-West Bay & 450432093005101 & $7 / 29 / 2011$ & 1145 & Lake & 36 & 2.9 & E6.1 & 34 & 48 & 150 & -0.1 \\
\hline WBLMP01 & 450409092574101 & $7 / 26 / 2011$ & 1400 & Pore water & 188 & 37 & 43 & 60 & 156 & 505 & -1.2 \\
\hline WBLMP02 & 450453092575501 & $7 / 27 / 2011$ & 1300 & Pore water & 34 & 30 & 23,300 & 124 & 129 & 319 & 2.8 \\
\hline WBLMP03 & 450505092581201 & $7 / 27 / 2011$ & 1445 & Pore water & 550 & 31 & 21,900 & 226 & 208 & 1,310 & -1.7 \\
\hline WBLMP04 & 450526092583701 & $7 / 28 / 2011$ & 0945 & Pore water & 143 & 29 & 904 & 200 & 184 & 642 & -1 \\
\hline WBLMP05 & 450544092590201 & $7 / 28 / 2011$ & 1145 & Pore water & 61 & 27 & 12,000 & 230 & 142 & 590 & 0.6 \\
\hline WBLMP07 & 450401092574401 & $7 / 28 / 2011$ & 1440 & Pore water & 208 & 27 & 18 & 59 & 184 & 578 & 0.2 \\
\hline WBLMP08 & 450426093005001 & $7 / 28 / 2011$ & 1645 & Pore water & 11 & 17 & 4,870 & 58 & 38 & 276 & -0.3 \\
\hline WBLMP09 & 450416093003801 & $7 / 29 / 2011$ & 1020 & Pore water & 23 & 31 & 6,830 & 202 & 197 & 446 & -1.7 \\
\hline WBLMP11 & 450517092595701 & $8 / 24 / 2011$ & 1545 & Pore water & 43 & 41 & 3,530 & 168 & 187 & 593 & 0.9 \\
\hline WBLMP12 & 450322092575701 & $8 / 25 / 2011$ & 1340 & Pore water & 70 & 28 & 11,500 & 166 & 144 & 384 & 1.6 \\
\hline GLMP13 & 450422093005101 & $8 / 30 / 2011$ & 1430 & Pore water & 75 & 15 & 507 & 105 & 122 & 341 & 0.2 \\
\hline GLMP14 & 450410093004201 & $8 / 31 / 2011$ & 1330 & Pore water & 67 & 5.8 & 296 & 37 & 33 & 207 & -1.3 \\
\hline BELMP15 & 450649093000501 & $8 / 31 / 2011$ & 1540 & Pore water & 286 & 46 & 21,000 & 508 & 370 & 969 & 2.4 \\
\hline BELMP16 & 450603093004201 & $9 / 1 / 2011$ & 1020 & Pore water & 59 & 43 & 11,400 & 243 & 176 & 512 & 0.3 \\
\hline GLA-1 & 450546093002401 & 8/9/2011 & 1220 & Well water & 98 & 33 & 4,350 & 318 & 207 & 569 & 1.6 \\
\hline GLA-2 & 450459092593001 & 8/9/2011 & 1400 & Well water & 23 & 29 & 8,840 & 77 & 77 & 284 & 3.1 \\
\hline GLA-3 & 450542093001501 & 8/9/2011 & 1605 & Well water & 28 & 27 & 143 & 138 & 171 & 359 & 2.7 \\
\hline GLA-4 & 450412092594002 & $8 / 23 / 2011$ & 1345 & Well water & 53 & 22 & 10,200 & 107 & 50 & 274 & 6.1 \\
\hline STP-2 & 450414093003701 & $8 / 12 / 2011$ & 1030 & Well water & 71 & 22 & 76 & 31 & 129 & 534 & 2.2 \\
\hline STP-1 & 450451092574201 & $8 / 12 / 2011$ & 1300 & Well water & 6.9 & 17 & 2,720 & 54 & 99 & 260 & 1.4 \\
\hline PDC-1 & 450508092580901 & $8 / 22 / 2011$ & 1645 & Well water & 15 & 20 & 2,910 & 163 & 108 & 264 & 0.1 \\
\hline PDC-2 & 450412092594001 & $8 / 30 / 2011$ & 1300 & Well water & 6.6 & 20 & 335 & 19 & 75 & 190 & -0.8 \\
\hline
\end{tabular}




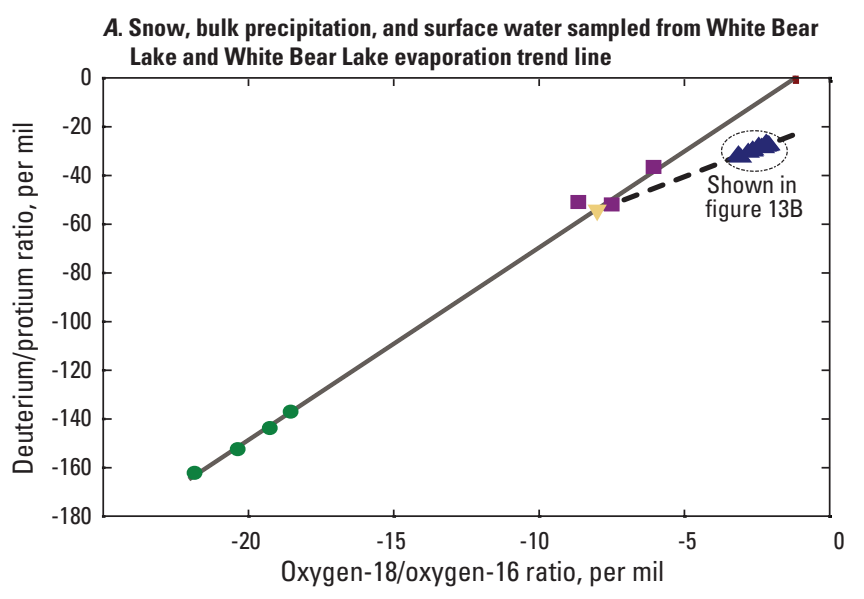

EXPLANATION

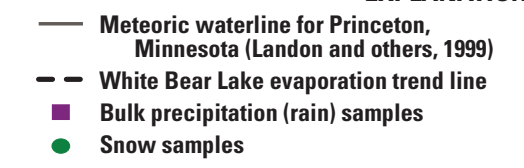

White Bear Lake surfacewater samples

$\checkmark$ Approximate weighted mean isotope compostion of

C. Well water sampled from 14 wells and surface waters sampled from White Bear Lake and groundwater/lake-water isotope mixing model for White Bear Lake area

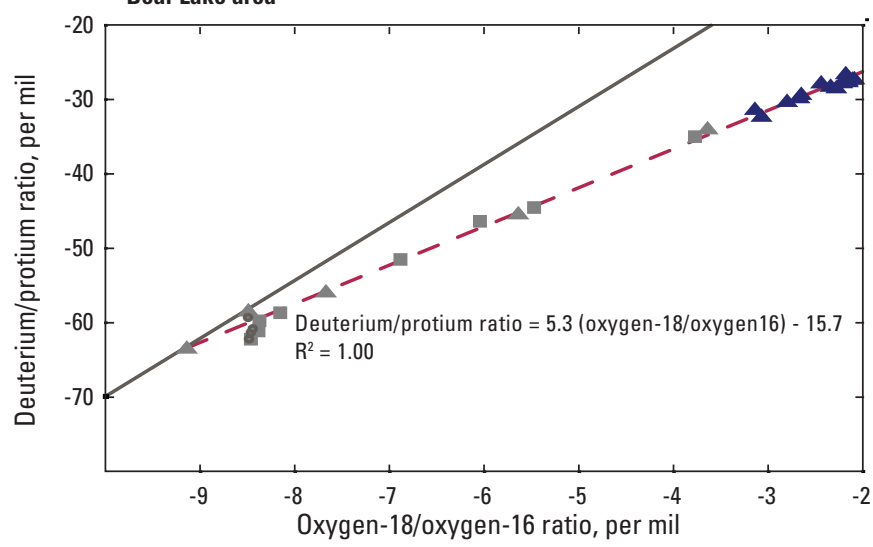

EXPLANATION
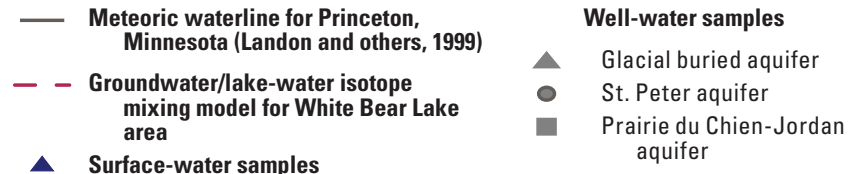

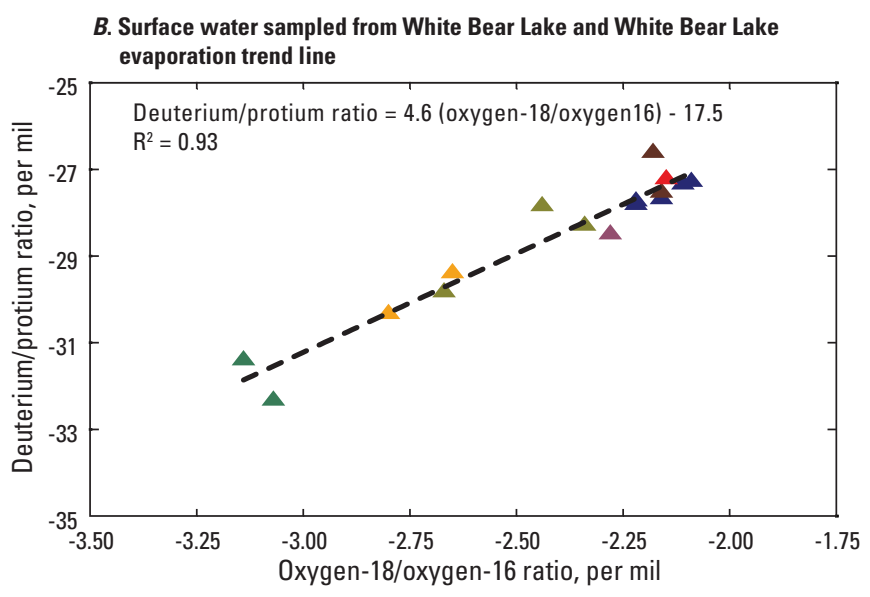

EXPLANATION

- White Bear Lake evaporation trend line

A November $2010 \quad \Delta$ July 2011

$\triangle$ March $2011 \quad \Delta$ September 2011

- May 2011

- October 2011

D. Pore water and surface water sampled from White Bear Lake

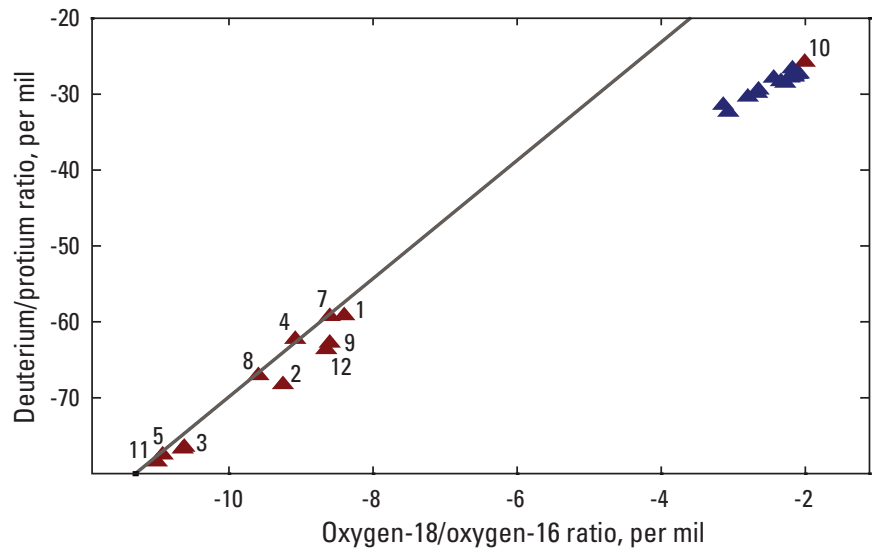

EXPLANATION

- Meteoric waterline for Princeton, Minnesota (Landon and others, 1999)

ore-water samples-Numbers are site identifiers

- Surface-water samples $\begin{array}{lr}1 \text { - WBLMP01 } & 8 \text { - WBLMP08 } \\ 2 \text { - WBLMP02 } & 9 \text { - WBLMP09 } \\ 3 \text { - WBLMP03 } & 10 \text { - WBLMP10 } \\ \text { 4 - WBLMP04 } & 11 \text { - WBLMP11 }\end{array}$

4 - WBLMPO

7 - WBLMP07

Figure 13. Comparison of oxygen-18/oxygen-16 ratios and deuterium/protium ratios with meteoric waterline for $A$, snow, bulk precipitation, and surface water sampled at or near White Bear Lake and White Bear Lake evaporation trend line; $B$, surface water sampled from White Bear Lake and White Bear Lake evaporation trend line; $C$, well water sampled from 14 wells and surface waters sampled from White Bear Lake, and groundwater/lake-water isotope mixing model for White Bear Lake area; and $D$, pore water and surface water sampled from White Bear Lake. 
Table 9. Water-quality data for precipitation, lake water, groundwater, and pore water collected at or near White Bear Lake, northeast Twin Cities Metropolitan Area, Minnesota, November 2010 through September 2011.

[mm, millimeters; $\mathrm{Hg}$, mercury; $\mu \mathrm{S} / \mathrm{cm}$ at $25^{\circ} \mathrm{C}$; microsiemens per centimeter at 25 degrees Celsius; ${ }^{\circ} \mathrm{C}$, degrees Celsius; mg/L, milligrams per liter; per mil, parts per thousand; E, estimated; --, no data]

\begin{tabular}{|c|c|c|c|c|c|c|c|c|c|c|c|c|c|c|}
\hline $\begin{array}{l}\text { Water-quality } \\
\text { sampling site }\end{array}$ & Site number & $\begin{array}{c}\text { Date } \\
\text { (month/ } \\
\text { day/year) }\end{array}$ & $\begin{array}{c}\text { Time } \\
\text { (24-hour) }\end{array}$ & Sample Type & $\begin{array}{c}\text { Baro- } \\
\text { metric } \\
\text { pressure, } \\
\text { on site } \\
\text { (mmHg) }\end{array}$ & $\begin{array}{c}\text { Specific } \\
\text { conductance, } \\
\text { on site } \\
(\mu \mathrm{S} / \mathrm{cm} \text { at } \\
\left.25^{\circ} \mathrm{C}\right)\end{array}$ & $\begin{array}{c}\text { Specific } \\
\text { conduc- } \\
\text { tance, } \\
\text { laboratory } \\
(\mu \mathrm{S} / \mathrm{cm} \text { at } \\
\left.25^{\circ} \mathrm{C}\right)\end{array}$ & $\begin{array}{c}\text { pH, on site } \\
\text { (standard } \\
\text { units) }\end{array}$ & $\begin{array}{l}\mathrm{pH}, \\
\text { labora- } \\
\text { tory }\end{array}$ & $\begin{array}{c}\text { Air } \\
\text { temperature } \\
\left({ }^{\circ} \mathrm{C}\right)\end{array}$ & $\begin{array}{c}\text { Water } \\
\text { temperature } \\
\left(^{\circ} \mathrm{C}\right)\end{array}$ & $\begin{array}{c}\text { Dissolved } \\
\text { oxygen, } \\
\text { on site } \\
\text { (mg/L) }\end{array}$ & $\begin{array}{c}\text { Oxygen-18/ } \\
\text { oxygen-16 } \\
\text { ratio, } \\
\text { unfiltered } \\
\text { water, } \\
\text { per mil }\end{array}$ & $\begin{array}{c}\text { Deuterium/ } \\
\text { protium } \\
\text { ratio, } \\
\text { unfiltered } \\
\text { water, } \\
\text { per mil }\end{array}$ \\
\hline Precipitation & 450334092574201 & $7 / 14 / 2011$ & 1410 & Precipitation & -- & -- & -- & -- & -- & -- & -- & -- & -7.49 & -52 \\
\hline Precipitation & 450334092574201 & $8 / 31 / 2011$ & 1050 & Precipitation & -- & -- & -- & -- & -- & -- & -- & -- & -6.05 & -36.5 \\
\hline Precipitation & 450334092574201 & $10 / 12 / 2011$ & 1800 & Precipitation & -- & -- & -- & -- & -- & -- & -- & -- & -8.64 & -50.8 \\
\hline WBL-Birch Beach & 450350092583901 & $3 / 14 / 2011$ & 1100 & Snow & -- & 11 & -- & -- & -- & -- & -- & -- & -21.85 & -162 \\
\hline $\begin{array}{l}\text { WBL-Ramsey County } \\
\text { Beach }\end{array}$ & 450536092594801 & $3 / 14 / 2011$ & 1015 & Snow & -- & 12 & -- & -- & -- & -- & -- & -- & -20.36 & -152 \\
\hline WBL-Bellaire Beach & 450416092594401 & $3 / 14 / 2011$ & 1120 & Snow & -- & 9 & -- & -- & -- & -- & -- & -- & -19.26 & -144 \\
\hline $\begin{array}{l}\text { Wetland at Peninsula } \\
\text { Road }\end{array}$ & 450458092580601 & $3 / 14 / 2011$ & 1030 & Snow & -- & 7 & -- & -- & -- & -- & -- & -- & -18.54 & -137 \\
\hline Bald Eagle Lake & 450650093000801 & $11 / 23 / 2010$ & 1530 & Lake & 746 & 428 & 428 & 7.2 & 7.2 & -- & 1.5 & 12.2 & -2.77 & -32.6 \\
\hline Bald Eagle Lake & 450650093000801 & 6/16/2011 & 1520 & Lake & 732 & 423 & -- & 8.6 & -- & -- & 21 & 11.8 & -4.2 & -39.7 \\
\hline Bald Eagle Lake & 450650093000801 & $8 / 3 / 2011$ & 1030 & Lake & 739 & 404 & 386 & 8 & 8.3 & 23 & 25.2 & 5 & -3.78 & -37 \\
\hline Birch Lake & 450456093020801 & $8 / 3 / 2011$ & 0945 & Lake & 739 & 362 & 352 & 7.5 & 7.3 & 18 & 25.2 & 6.3 & -3.35 & -31.5 \\
\hline Echo Lake & 450512092574901 & $8 / 3 / 2011$ & 1600 & Lake & 739 & 76 & E76 & 6.3 & E6.6 & 29 & 28 & 3.9 & -2.8 & -34.7 \\
\hline Goose Lake & 450424093005701 & 7/29/2011 & 1330 & Lake & 740 & 368 & 361 & 9.5 & 9.8 & -- & 27.6 & 8 & -3.75 & -37.1 \\
\hline Long Lake & 450437092564101 & 8/3/2011 & 1645 & Lake & 739 & 246 & 240 & 7.1 & 7.3 & 28.5 & 33 & 3.5 & -5.71 & -43.1 \\
\hline Lost Lake & 450306092575901 & $11 / 22 / 2010$ & 1030 & Lake & 730 & 309 & -- & 8.2 & -- & -- & 1.9 & 11.6 & -5.3 & -47.9 \\
\hline Lost Lake & 450306092575901 & $8 / 3 / 2011$ & 1730 & Lake & 739 & 311 & 303 & 7 & 7.4 & -- & 25.7 & 3 & -5.89 & -42.2 \\
\hline Mann Lake & 450641092554601 & $8 / 3 / 2011$ & 1345 & Lake & 739 & 125 & 125 & 7.8 & 7.3 & 28.5 & 28.7 & 6.2 & -4.92 & -44.7 \\
\hline Pine Tree Lake & 450618092572001 & $8 / 3 / 2011$ & 1215 & Lake & 739 & 134 & 132 & 9.3 & 9 & 26 & 27.4 & 9.4 & -3.52 & -36.9 \\
\hline Sunset Lake & 450743092563101 & $8 / 3 / 2011$ & 1445 & Lake & 739 & 181 & 172 & 9.2 & 9.2 & 28.5 & 29.4 & 8.8 & -3.4 & -35.5 \\
\hline Turtle Lake & 450534093075101 & 8/3/2011 & 0845 & Lake & 739 & 321 & 313 & 8.4 & 8.3 & 18 & 25 & 6.7 & -2.71 & -30.2 \\
\hline WBL-Bellaire Beach & 450416092594401 & $5 / 9 / 2011$ & 1600 & Lake & -- & -- & -- & -- & -- & -- & -- & -- & -3.14 & -31.4 \\
\hline WBL-Birch Beach & 450350092583901 & $11 / 22 / 2010$ & 1010 & Lake & 730 & 305 & -- & 8.3 & -- & -- & 2.1 & 12.9 & -2.09 & -27.3 \\
\hline WBL-Mahtomedi Beach & 450410092574101 & $7 / 26 / 2011$ & 1430 & Lake & 732 & 291 & 291 & 8.9 & 8.8 & -- & 28.1 & 9.8 & -2.67 & -29.8 \\
\hline WBL-Manitou Island & 450441092592501 & $11 / 22 / 2010$ & 1320 & Lake & 730 & 308 & -- & 8.3 & -- & -- & 1.4 & 13.3 & -2.22 & -27.7 \\
\hline $\begin{array}{l}\text { WBL-Ramsey County } \\
\text { Beach }\end{array}$ & 450536092594801 & $11 / 22 / 2010$ & 1200 & Lake & 730 & 307 & -- & 8.2 & -- & -- & 2.1 & 12.4 & -2.11 & -27.3 \\
\hline $\begin{array}{l}\text { WBL-Ramsey County } \\
\text { Beach }\end{array}$ & 450536092594801 & $6 / 16 / 2011$ & 1550 & Lake & 733 & 297 & -- & 8.8 & -- & -- & 20.2 & 11.6 & -2.8 & -30.3 \\
\hline $\begin{array}{l}\text { WBL-Southeast Bay (40 } \\
\mathrm{ft} \text { below lake surface) }\end{array}$ & 450358092580601 & $3 / 14 / 2011$ & 1520 & Lake & -- & 342 & -- & -- & -- & -- & 4.6 & -- & -2.37 & -30.2 \\
\hline $\begin{array}{l}\text { WBL-Southeast Bay ( } 5 \mathrm{ft} \\
\text { below lake surface) }\end{array}$ & 450358092580601 & $3 / 14 / 2011$ & 1540 & Lake & -- & 318 & -- & -- & -- & -- & 3.4 & -- & -2.28 & -28.5 \\
\hline $\begin{array}{l}\text { WBL-Southeast Bay (72 } \\
\text { ft below lake suface) }\end{array}$ & 450358092580601 & $3 / 14 / 2011$ & 1500 & Lake & -- & 366 & -- & -- & -- & -- & 5.2 & -- & -2.35 & -29.2 \\
\hline WBL-West Bay & 450432093005101 & $11 / 22 / 2010$ & 0900 & Lake & 730 & 320 & -- & 8.2 & -- & -- & 0.2 & 13.4 & -2.22 & -27.8 \\
\hline WBL-West Bay & 450432093005101 & $5 / 9 / 2011$ & 1540 & Lake & -- & -- & -- & -- & -- & -- & -- & -- & -3.07 & -32.3 \\
\hline WBL-West Bay & 450432093005101 & $6 / 16 / 2011$ & 1630 & Lake & 733 & 296 & -- & 8.8 & -- & -- & 21.4 & 9.4 & -2.65 & -29.4 \\
\hline WBL-West Bay & 450432093005101 & 7/29/2011 & 1145 & Lake & 740 & 265 & 262 & 9.2 & 9 & -- & 27.3 & 9.3 & -2.44 & -27.8 \\
\hline WBL-West Bay & 450432093005101 & 9/8/2011 & 1415 & Lake & -- & 274 & -- & 8.9 & -- & -- & 22.9 & 11.4 & -2.16 & -27.5 \\
\hline
\end{tabular}


Table 9. Water-quality data for precipitation, lake water, groundwater, and pore water collected at or near White Bear Lake, northeast Twin Cities Metropolitan Area, Minnesota, November 2010 through September 2011.-Continued

[mm, millimeters; $\mathrm{Hg}$, mercury; $\mu \mathrm{S} / \mathrm{cm}$ at $25^{\circ} \mathrm{C}$; microsiemens per centimeter at 25 degrees Celsius; ${ }^{\circ} \mathrm{C}$, degrees Celsius; mg/L, milligrams per liter; per mil, parts per thousand; E, estimated; --, no data]

\begin{tabular}{|c|c|c|c|c|c|c|c|c|c|c|c|c|c|c|}
\hline $\begin{array}{l}\text { Water-quality } \\
\text { sampling site }\end{array}$ & Site number & $\begin{array}{c}\text { Date } \\
\text { (month/ } \\
\text { day/year) }\end{array}$ & $\begin{array}{c}\text { Time } \\
\text { (24-hour) }\end{array}$ & Sample Type & $\begin{array}{c}\text { Baro- } \\
\text { metric } \\
\text { pressure, } \\
\text { on site } \\
(\mathrm{mmHg})\end{array}$ & $\begin{array}{c}\text { Specific } \\
\text { conductance, } \\
\text { on site } \\
(\mu \mathrm{S} / \mathrm{cm} \text { at } \\
\left.25^{\circ} \mathrm{C}\right)\end{array}$ & $\begin{array}{l}\text { Specific } \\
\text { conduc- } \\
\text { tance, } \\
\text { laboratory } \\
(\mu \mathrm{S} / \mathrm{cm} \text { at } \\
\left.25^{\circ} \mathrm{C}\right)\end{array}$ & $\begin{array}{c}\text { pH, on site } \\
\text { (standard } \\
\text { units) }\end{array}$ & $\begin{array}{c}\mathrm{pH}, \\
\text { labora- } \\
\text { tory }\end{array}$ & $\begin{array}{c}\text { Air } \\
\text { temperature } \\
\left({ }^{\circ} \mathrm{C}\right)\end{array}$ & $\begin{array}{c}\text { Water } \\
\text { temperature } \\
\left({ }^{\circ} \mathrm{C}\right)\end{array}$ & $\begin{array}{l}\text { Dissolved } \\
\text { oxygen, } \\
\text { on site } \\
\text { (mg/L) }\end{array}$ & $\begin{array}{l}\text { Oxygen-18/ } \\
\text { oxygen-16 } \\
\text { ratio, } \\
\text { unfiltered } \\
\text { water, } \\
\text { per mil }\end{array}$ & $\begin{array}{l}\text { Deuterium/ } \\
\text { protium } \\
\text { ratio, } \\
\text { unfiltered } \\
\text { water, } \\
\text { per mil }\end{array}$ \\
\hline WBL-West Bay & 450432093005101 & $10 / 6 / 2011$ & 1245 & Lake & -- & 296 & -- & 8.8 & -- & -- & 17.3 & 11 & -2.15 & -27.2 \\
\hline WBLMP10 & 450441092592502 & $11 / 22 / 2010$ & 1350 & Pore water & 730 & 438 & -- & 7.3 & -- & -- & 4.4 & 0.2 & -2.01 & -25.7 \\
\hline WBLMP01 & 450409092574101 & 7/26/2011 & 1400 & Pore water & 732 & 910 & 892 & 6.3 & 6.7 & -- & 19.2 & 0.9 & -8.4 & -59.1 \\
\hline WBLMP02 & 450453092575501 & 7/27/2011 & 1300 & Pore water & 732 & 480 & 407 & 6.7 & 6.9 & -- & 17.1 & 0.9 & -9.25 & -68.2 \\
\hline WBLMP03 & 450505092581201 & $7 / 27 / 2011$ & 1445 & Pore water & 739 & 2,220 & 2120 & 6.3 & 6.8 & -- & 20.3 & 0.8 & -10.64 & -76.7 \\
\hline WBLMP04 & 450526092583701 & $7 / 28 / 2011$ & 0945 & Pore water & 737 & 1,120 & 1100 & 6.9 & 7.3 & -- & 18.2 & 1.3 & -9.08 & -62.2 \\
\hline WBLMP05 & 450544092590201 & 7/28/2011 & 1145 & Pore water & 737 & 1,120 & 959 & 6.9 & 7.1 & -- & 22.2 & 1 & -10.92 & -77.5 \\
\hline WBLMP07 & 450401092574401 & 7/28/2011 & 1440 & Pore water & 737 & 915 & 916 & 6.2 & 6.7 & -- & 18.6 & 8.3 & -8.6 & -59.2 \\
\hline WBLMP08 & 450426093005001 & $7 / 28 / 2011$ & 1645 & Pore water & 737 & 424 & 416 & 6.7 & 7.3 & -- & 14.9 & 1.2 & -9.59 & -67 \\
\hline WBLMP09 & 450416093003801 & 7/29/2011 & 1020 & Pore water & 740 & 760 & 730 & 6.6 & 7 & -- & 17.4 & 1 & -8.6 & -62.7 \\
\hline WBLMP11 & 450517092595701 & $8 / 24 / 2011$ & 1545 & Pore water & 732 & 890 & 877 & 7 & 7.3 & -- & 25.2 & -- & -11 & -78.4 \\
\hline WBLMP12 & 450322092575701 & $8 / 25 / 2011$ & 1340 & Pore water & 739 & 662 & 636 & 6.7 & 7 & -- & 18.6 & 0.9 & -8.65 & -63.6 \\
\hline GLMP13 & 450422093005101 & $8 / 30 / 2011$ & 1430 & Pore water & 737 & 650 & 613 & 7.8 & 7.4 & -- & 23.4 & 0.9 & -3.72 & -36.1 \\
\hline GLMP14 & 450410093004201 & $8 / 31 / 2011$ & 1330 & Pore water & 736 & 397 & 360 & 7.7 & 7.3 & -- & 23.4 & 1.6 & -3.33 & -34.4 \\
\hline BELMP15 & 450649093000501 & $8 / 31 / 2011$ & 1540 & Pore water & 736 & 1,920 & 1630 & 6.6 & 6.9 & -- & 22.9 & 3.5 & -8.72 & -62.5 \\
\hline BELMP16 & 450603093004201 & 9/1/2011 & 1020 & Pore water & 733 & 916 & 807 & 6.9 & 7.2 & -- & 23.4 & E2.5 & -4.57 & -43.3 \\
\hline GLA-1 & 450546093002401 & 8/9/2011 & 1220 & Groundwater & 732 & 928 & 953 & 7.4 & 8.1 & -- & 11.5 & 0.1 & -9.14 & -63.5 \\
\hline GLA-2 & 450459092593001 & 8/9/2011 & 1400 & Groundwater & 732 & 444 & 428 & 7.2 & 7.9 & -- & 11.2 & 0.1 & -3.64 & -34 \\
\hline GLA-3 & 450542093001501 & 8/9/2011 & 1605 & Groundwater & 732 & 594 & 605 & 7.6 & 8.1 & -- & 10.5 & 0.1 & -5.64 & -45.4 \\
\hline GLA-4 & 450412092594002 & 8/23/2011 & 1345 & Groundwater & 732 & 473 & 453 & 6.6 & 6.9 & -- & 10.9 & 0.1 & -8.49 & -58.5 \\
\hline GLA-5 & 450540093001201 & 8/11/2011 & 1345 & Groundwater & 737 & 617 & -- & 7.7 & -- & -- & 10.9 & E0 & -7.67 & -55.9 \\
\hline STP-1 & 450451092574201 & $5 / 10 / 2011$ & 1500 & Groundwater & -- & 448 & -- & 7.5 & -- & -- & 10.8 & 0.1 & -8.46 & -61.3 \\
\hline STP-1 & 450451092574201 & $8 / 12 / 2011$ & 1300 & Groundwater & 735 & 453 & 456 & 7.5 & 7.7 & -- & 9.7 & 0.01 & -8.48 & -62.2 \\
\hline STP-2 & 450414093003701 & $8 / 12 / 2011$ & 1030 & Groundwater & 735 & 898 & 915 & 7 & 7.4 & -- & 11.5 & 2.2 & -8.44 & -60.8 \\
\hline JOR-1 & 450342092592601 & $11 / 4 / 2011$ & 0930 & Groundwater & -- & -- & -- & -- & -- & -- & -- & -- & -5.47 & -44.5 \\
\hline JOR-2 & 450214092581201 & $11 / 15 / 2011$ & 0810 & Groundwater & -- & -- & -- & -- & -- & -- & -- & -- & -8.15 & -58.7 \\
\hline PDCJ-1 & 450302092583701 & $11 / 15 / 2011$ & 0825 & Groundwater & -- & -- & -- & -- & -- & -- & -- & -- & -6.04 & -46.4 \\
\hline PDCJ-2 & 450357092594401 & 11/4/2011 & 0910 & Groundwater & -- & -- & -- & -- & -- & -- & -- & -- & -6.88 & -51.5 \\
\hline PDCJ-3 & 450415092570101 & $11 / 15 / 2011$ & 0840 & Groundwater & -- & -- & -- & -- & -- & -- & -- & -- & -8.37 & -59.8 \\
\hline PDC-1 & 450508092580901 & $5 / 11 / 2011$ & 1608 & Groundwater & 735 & 452 & -- & 7.5 & -- & -- & 10.9 & 0.4 & -8.38 & -61.1 \\
\hline PDC-1 & 450508092580901 & $8 / 22 / 2010$ & 1645 & Groundwater & 740 & 460 & 465 & 7.8 & 7.7 & -- & 9.9 & 0.1 & -8.46 & -62.2 \\
\hline PDC-2 & 450412092594001 & $8 / 30 / 2011$ & 1300 & Groundwater & 737 & 353 & 345 & 7.4 & 7.8 & -- & 11.8 & E0.1 & -3.77 & -35 \\
\hline
\end{tabular}




\section{Autonomous, Underwater Vehicle Survey}

Temperatures measured near the shoreline by the AUV correlated with pore-water temperature measurements, indicating potential areas of groundwater inflow to the lake. Negative temperature anomalies measured at shallow water depths in the water-quality survey indicated several shallow-water areas where groundwater may be flowing into the lake. Negative temperature anomalies indicated the observed temperature at a specific location was less than the median value for that sample depth. Temperature anomalies ranging from -0.1 to -0.5 were measured in shallow water areas along the eastern and southern shores of the lake (fig. 14A). Cooler lakesediment temperatures (as indicated by negative anomalies) measured during the lake-sediment temperature survey were recorded at three of the east-shore areas. These negative temperature anomalies were in near-shore waters at water depths generally less than $15 \mathrm{ft}$. At these depths, the AUV generally was operated at the water surface to avoid being snagged by milfoil. If the AUV had been able to survey closer to the sediment-water interface, the AUV may have measured larger negative temperature anomalies. Temperatures less than $15^{\circ} \mathrm{C}$ and dissolved oxygen concentrations near $0 \mathrm{mg} / \mathrm{L}$ were measured at several areas where water depths were greater than $40 \mathrm{ft}$ (figs. $14 A$ and $C$ ). In the deepest part of the lake where the lake core was collected, negative temperature, $\mathrm{pH}$, and dissolved-oxygen anomalies were determined. Cool temperatures, low $\mathrm{pH}$, and low concentrations of dissolved oxygen are common in deeper waters of most temperate-zone lakes that experience strong seasonal climatic changes (Wetzel, 1983). Relatively warm lake-sediment temperatures were recorded in July 2011 at several areas along the eastern shore (fig. 15) where negative temperature anomalies were determined by the AUV at shallow depths. Offshore groundwater inflow or upwelling of cooler lake waters below the thermocline may have taken place at these locations, allowing the cool water temperatures to be measured in the water-quality survey but not in the shoreline sediments.

Specific conductance measured by the AUV provided little indication of groundwater inflows to the lake (fig. 14B). The positive anomalies in specific conductance are offset by similar magnitude negative anomalies indicating noise in the AUV data may be responsible for these anomalies. However, the positive anomalies are primarily in the deepest part of the lake where the maximum specific conductance was measured at the base of the thermocline (about $40 \mathrm{ft}$ ), as shown in the median vertical profile (fig. 14B).

Most of the water-quality data and anomalies determined from the AUV surveys depended mainly on depth, complicating the interpretation of the data and detection of groundwater flows to the lake. Median vertical waterquality profiles measured by the AUV indicated a summer stratification typically seen in most temperate-zone lakes that experience strong seasonal climatic changes (fig. 14; Wetzel, 1983). Generally, water-quality values were uniform from the water surface down to water depths between 16 and $22 \mathrm{ft}$, indicating well-mixed water at shallow depths (surface mixed layer). The thermocline generally extended between 16 and $42 \mathrm{ft}$ below the water surface, with some slight variation across the lake (fig. 14). In the northern part of the lake, the top of the thermocline was at a depth of about $22 \mathrm{ft}$. Within the thermocline, temperatures gradually decreased from approximately 25 to $10^{\circ} \mathrm{C}$, dissolved oxygen concentrations gradually decreased from approximately 9 to $0 \mathrm{mg} / \mathrm{L}$, and $\mathrm{pH}$ values decreased from approximately 8.6 to 7.8. Specific conductance generally increased with depth in the thermocline until reaching a maximum of 315 microsiemens per centimeter at $25^{\circ} \mathrm{C}(\mu \mathrm{S} / \mathrm{cm})$ near the base of the thermocline (fig. 14B). All measured water-quality properties varied little with depth in the surface mixed layer and in the hypolimnion (water depth below $42 \mathrm{ft}$ ) (fig. 14).

Despite applying temporal lag corrections to each of the sensors' data, some residual response time-induced errors remain in the data. "Leopard spot" patterns of alternating positive and negative anomalies were observed in the spatial distributions of anomalies for specific conductance, temperature, and dissolved oxygen (fig. 14). These anomalies are primarily because of the time lags in the sensor response, which cannot be adequately accounted for by applying a constant-value temporal shift. These anomalous, repeated patterns are highly correlated with AUV dive speed, can be easily identified in the data, and are removed from consideration during data interpretation. These issues are most prominent in the deepest part of the lake because of a combination of an increase in the dive speed and dive angle of the AUV in this region to accommodate the desired spatial resolution and extent of the survey within the run-time constraints of the AUV. Interpretation of the data focused on identification of anomalies that were repeatable and larger in magnitude and spatial extent compared to the spotted patterns originating from issues of sensor response time and dive speed.

\section{Lake-Sediment Temperature Survey}

Of the 298 lake-sediment temperatures measured at White Bear Lake, 19 measurements in 8 areas along the northeast, east, south, and southwest shores of White Bear Lake were below $18^{\circ} \mathrm{C}$ (fig. 15), indicating potential areas for groundwater inflow to the lake. Lake-sediment temperatures in White Bear Lake measured between July 20 and August 2, 2011, ranged from 12.2 to $29.9^{\circ} \mathrm{C}$ (table 1-9 in the appendix), averaging $24.4^{\circ} \mathrm{C}$. Surface-water temperatures measured in the lake during the lake-sediment temperature surveys ranged from 19.8 to $33.3^{\circ} \mathrm{C}$ (table 1-9), averaging $28.8^{\circ} \mathrm{C}$. Iron-stained sediments commonly were present at the eight areas where lake-sediment temperatures were below $18^{\circ} \mathrm{C}$. These iron stains were visible at areas of cool temperatures in aerial photos taken during ice-out in April 2006 (Minnesota Geospatial Information Office, 2013). Seepage-meter measurements were made in August following the lake-sediment temperature survey at the eight and other areas where cool lake-sediment temperatures were measured to determine if groundwater might be flowing into the lake at those areas, and if so, the amount of groundwater flow into the lake. 

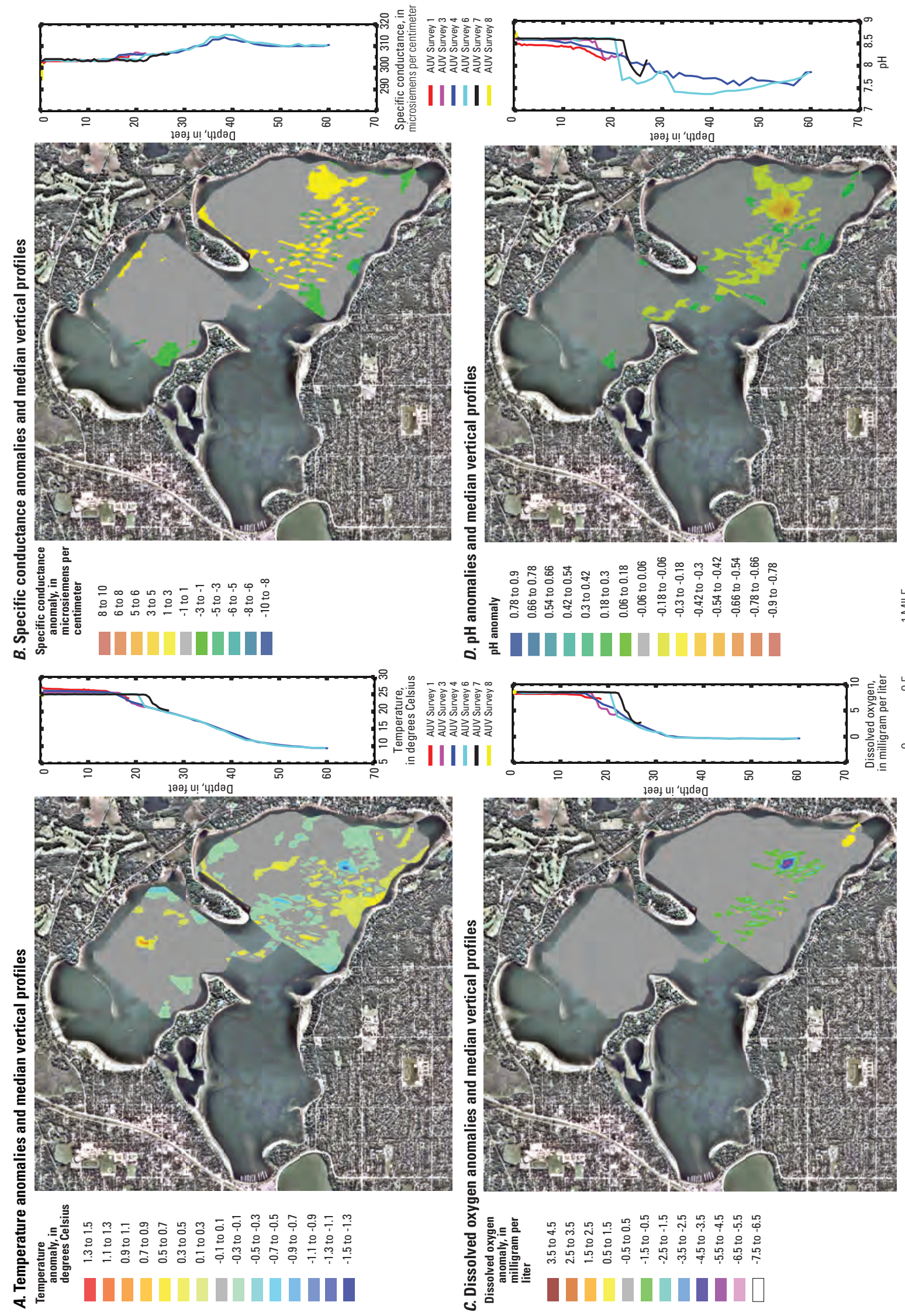

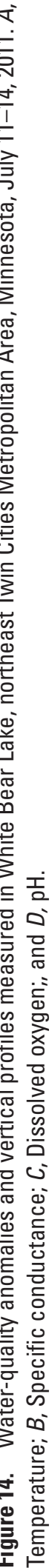




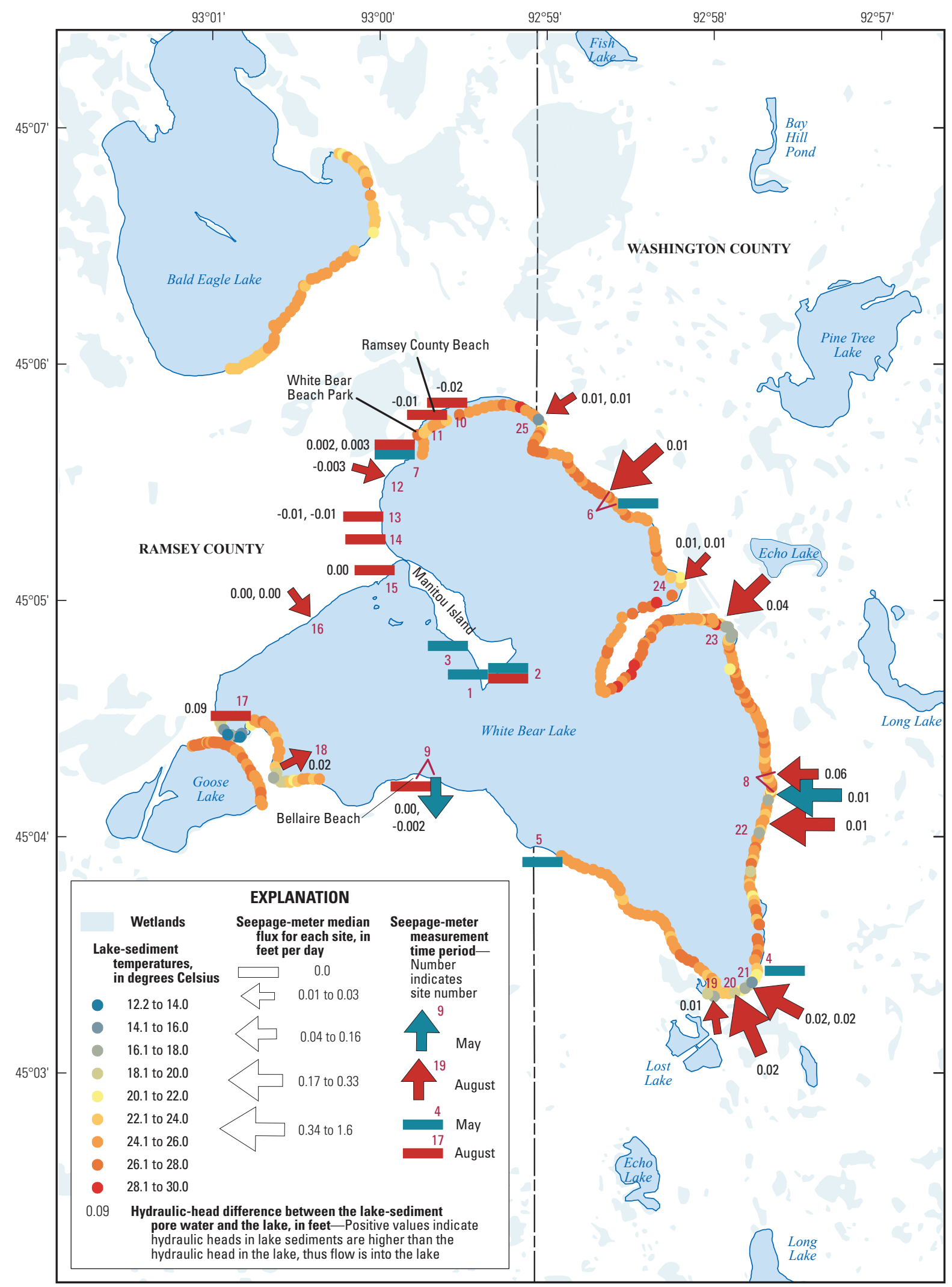

Base data from Minnesota Department of Natural Resources digital data, 1:24,000 and U.S. Geological Survey, 1:100,000

Universal Transverse Mercator projection, Zone 15

Horizontal coordinate information is referenced to

the North American Datum of 1983 (NAD 83)

Figure 15. Lake-sediment temperatures, hydraulic-head differences, and seepage-meter median flux rates along the shore of White Bear Lake, Goose Lake, and Bald Eagle Lake, northeast Twin Cities Metropolitan Area, Minnesota, July through September 2011. 
All lake-sediment temperatures measured in Bald Eagle and Goose Lake were higher than $18^{\circ} \mathrm{C}$. Lake-sediment temperatures in Bald Eagle Lake were measured on August 26 and 29 and ranged from 19.9 to $25.1^{\circ} \mathrm{C}$ (fig. 15; table 1-9), averaging $23.8^{\circ} \mathrm{C}$. Lake-sediment temperatures in Goose Lake were measured on July 27 and ranged from 21.7 to $27.7^{\circ} \mathrm{C}$ (fig. 15; table 1-9), averaging $25.7^{\circ} \mathrm{C}$. Surface-water temperature in Goose Lake was $24.5^{\circ} \mathrm{C}$ on July 27. Although no cool temperatures were measured, groundwater may be flowing into the lakes at areas that were not measured, or inflowing groundwater may be relatively warm if flowing from other surrounding lakes or wetlands prior to reaching these lakes.

\section{Properties, Major Constituents, and Stable Isotopes}

The percentage differences in the ionic balances were less than \pm 5 percent for all but three of the surface-water samples collected at lakes in the northeast TCMA (table 8), indicating the major constituents were in good balance for most of the samples. Surface-water samples collected at Mann Lake, Echo Lake, and Pine Tree Lake had differences of 11, 6.2, and 5.5 percent, respectively. The specific conductances in waters from these three lakes were the lowest values measured in all the sampled lakes (table 8), reflecting very low concentrations of total dissolved ions. Hem (1985) stated that for constituent concentrations greater than $100 \mathrm{mg} / \mathrm{L}$, differences should be less than \pm 5 percent, and for concentrations less than $1 \mathrm{mg} / \mathrm{L}$, differences generally are not less than \pm 10 percent and can be higher. Concentrations for all 17 major constituents (anions and cations) analyzed in the water samples from Mann, Echo, and Pine Tree Lakes were all less than $50 \mathrm{mg} / \mathrm{L}$. The low concentrations of dissolved ions in the surface-water samples from Mann Lake and Pine Tree Lake made it difficult to produce percentage differences in the ionic balances less than \pm 5 percent.

Water sampled from White Bear, Bald Eagle, and Turtle Lakes contained similar concentrations of major constituents and specific conductance (table 8). Water samples from the lakes also had high alkalinity values and similar concentrations of calcium, magnesium, sulfate, and silica (table 8). Water sampled from White Bear Lake at Mahtomedi Beach on the east shore of the lake had slightly higher cation concentrations and a higher alkalinity value than water sampled from the West Bay of White Bear Lake (table 8). These concentration variations may be due in part to 0.42 in. of rainfall added to the lake on July 27 , which may have slightly diluted lake water from the West Bay more than water at Mahtomedi Beach.

Water from lakes that have relatively higher lake-level elevations had low specific conductances and concentrations of major ions. Specific conductance and concentrations of major ions were very low in water from Sunset, Mann, Pine Tree, and Echo Lakes (table 8). Specific conductance in water from these four lakes ranged from 76 to $181 \mu \mathrm{S} / \mathrm{cm}$; specific conductance in water from the other seven lakes sampled ranged from 246 to $404 \mu \mathrm{S} / \mathrm{cm}$. Sunset, Mann, Pine Tree, and
Echo Lakes are relatively high in elevation compared to the other seven sampled lakes, being at or near the top of their watersheds. Lakes in the upper parts of their watershed typically receive a larger part of their water from direct precipitation, which contains low concentrations of dissolved ion (Hem, 1985). Groundwater flowing to these lakes typically is from recently recharged waters from shallow aquifers. This groundwater likely has lower ionic concentrations compared to groundwater contributing to lakes lower in the watersheds because the groundwater has had less contact time with aquifer sediments. The concentrations of dissolved ions originating from the aquifer material are governed by kinetics of mineral dissolution. Concentrations of dissolved ions will tend to increase with longer contact time until equilibrium is reached (Kenoyer and Bowser, 1992).

Water from small lakes bordering a major road had relatively high concentrations of sodium and chloride. Concentrations of sodium and chloride were higher in surface water from Goose, Birch, and Lost Lakes than in surface waters from the other sampled lakes (table 8). These lakes are small and border roads that can be heavily salted during the winter months (fig. 1). Sodium concentrations in these lakes were greater than $25 \mathrm{mg} / \mathrm{L}$, and sodium was the dominant cation in the lakes. Chloride concentrations in these lakes were greater than $45 \mathrm{mg} / \mathrm{L}$. The application of road salt is a likely explanation for the high concentrations of sodium and chloride observed in Goose, Birch, and Lost Lakes.

The oxygen-18/oxygen-16 and deuterium/protium ratios for surface-water samples collected from White Bear Lake plotted along a linear regression trend line, referred to as the evaporation trend line for White Bear Lake for 2011 (figs. 13A and $13 B$ ). Oxygen-18/oxygen-16 ratios for surface-water samples collected from White Bear Lake ranged from -3.14 to -2.09 per mil (figs. $13 A$ and $13 B$ ), and deuterium/protium ratios ranged from -32.3 to -27.2 per mil (table 9 ). The intersection point between the White Bear Lake evaporation trend line and the meteoric water line (fig. 13A) from Landon and others (2009) $(-8.2,-55.4)$ is the approximate weighted mean isotopic composition of local precipitation (Gibson and Edwards, 2002). The slope of this trend line (4.6) was similar to slopes for evaporation trend lines determined for lakes in Wisconsin (Krabbenhoft and others, 1990) and Canada (Gibson and Edwards, 2002).

Oxygen-18/oxygen-16 and deuterium/protium ratios for surface-water samples collected from White Bear Lake varied seasonally with variations in evaporation rates. The lowest ratios were in the May samples following snowmelt; the highest ratios were in late summer and fall (fig. 13B). Snow around White Bear Lake had much lower oxygen-18/oxygen-16 and deuterium/protium ratios than the surface-water samples (fig. 13A; table 9). As the snow melted in early spring, melt waters with low ratios flowed into White Bear Lake, decreasing the ratios for the surface water in May. As temperatures increase in the late spring and summer, evaporation rates on the lake surface gradually increased, preferentially evaporating oxygen-16 over oxygen-18. As a result, oxygen-18/oxygen-16 
and deuterium/protium ratios in the surface water of the lake gradually increased in late spring and summer to the highest ratios in late summer and fall (fig. 13B).

Oxygen-18/oxygen-16 and deuterium/protium ratios for surface-water samples collected from lakes in the northeast TCMA generally were lower than ratios measured in surface waters from White Bear Lake (table 9). Oxygen-18/oxygen-16 ratios ranged from -5.89 to -2.71 per mil, and deuterium/ protium ratios ranged from -47.9 to -30.2 per mil for surfacewater samples collected from lakes in the northeast TCMA (table 9). The ratios from these lakes generally plotted below the evaporation trend line for White Bear Lake.

\section{Pore-Water Quality}

The percentage differences in the ionic balances were less than \pm 5 percent for all the pore-water samples collected at White Bear Lake, Goose Lake, and Bald Eagle Lake (table 8), indicating the major constituents were in good balance for all the pore-water samples. High concentrations of dissolved iron and manganese and low dissolved oxygen concentrations were common in pore-water samples collected in the lake sediments around White Bear Lake. Dissolved iron concentrations were greater than $3.0 \mathrm{mg} / \mathrm{L}$, dissolved manganese concentrations were greater than $0.15 \mathrm{mg} / \mathrm{L}$, and dissolved oxygen concentrations were less than $1.5 \mathrm{mg} / \mathrm{L}$ for 7 of the 10 pore-water samples collected for analyses of major constituents along the shoreline of White Bear Lake (table 8). The locations of these seven samples were not concentrated in any particular part of the shoreline (fig. 3; table 8). High concentrations of iron and manganese are typical in the Superior lobe tills present in the Quaternary sediment in the White Bear Lake area (Swanson and Meyer, 1990; Lively and Thorleifson, 2009). Iron staining is common along the eastern shore of White Bear Lake; evidence of iron precipitation is visible from inflowing groundwater with high concentrations of dissolved iron. When anoxic groundwater containing high concentrations of dissolved iron is exposed to the air, the dissolved iron will oxidize and precipitate out of solution as a reddish-brown, iron-oxide precipitate (Hem, 1985). Iron precipitates were visible at two pore-water sample sites (WBLMP01 and WBLMP07). The pore-water samples at these two sites had concentrations of dissolved iron less than $0.05 \mathrm{mg} / \mathrm{L}$ and concentrations of dissolved manganese less than $0.05 \mathrm{mg} / \mathrm{L}$ (table 8). Pore-water samples at sites WBLMP01 and WBLMP07 had dissolved oxygen concentrations of 0.9 and $8.3 \mathrm{mg} / \mathrm{L}$, respectively. The high concentration of dissolved oxygen at site WBLMP07 was recognized during sample collection and confirmed with a second mini-piezometer insertion. Seepage-meter flux measurements at site WBLMP07 were among the highest groundwater inflow fluxes recorded at White Bear Lake (table 1-10 in the appendix, seepage-meter site 22). Lake sediments at site WBLMP07 consisted of gravels and cobbles, which likely allow lake water to enter the mini-piezometer during porewater sampling, thus the water sample likely is not only pore water, but a mixture of lake water and pore water.
The difference in specific conductance between surface waters in White Bear Lake and pore waters collected in this study ranged from 100 to $1,900 \mu \mathrm{S} / \mathrm{cm}$ (table 8 ). Concentrations of sodium and chloride were greater than 70 and $150 \mathrm{mg} / \mathrm{L}$, respectively, in three pore-water samples (sites WBLMP01, WBLMP03, and WBLMP07) sampled in lake sediments on the eastern shore of White Bear Lake (fig. 3; table 8). Concentrations of sodium and chloride were the largest, 257 and $550 \mathrm{mg} / \mathrm{L}$, respectively, in pore water at site WBLMP03 on the northeast shore of White Bear Lake (fig. 3). Pore waters from this site likely are affected by subsurface flow from a wetland immediately to the east and upgradient from this site. A State highway crosses this wetland, which likely receives substantial sodium and chloride inputs from road-salt application to the highway in the winter months. No direct channel to the lake from the wetland exists, so travel time for sodium and chloride is governed by subsurface flow conditions through the glacial water-table aquifer. The concentrations of sodium, chloride, and other major constituents were not high in the pore-water sample collected at site WBLMP02, which is near site WBLMP03 (fig. 3; table 8). The wetland to the east and upgradient from site WBLMP02 is bordered by fewer roads and, therefore, likely received less sodium chloride from road-salt application. This wetland has a surfacewater outlet to White Bear Lake, and therefore, most of the sodium and chloride that did enter the wetland from winter road salting likely flushed through the wetland and into White Bear Lake during spring snowmelt. Chloride concentrations in White Bear Lake have been steadily increasing over the past five decades (McComas and Stuckert, 2006). In the 1960s, the chloride concentration in White Bear Lake was $5 \mathrm{mg} / \mathrm{L}$ (McComas and Stuckert, 2006); the average concentration determined in this study was $36 \mathrm{mg} / \mathrm{L}$. Seepage fluxes at sites WBLMP01 and WBLMP03 (seepage-meter sites 8 and 24) (fig. 3; table 1-10) were not as high relative to fluxes recorded at many sites around White Bear Lake.

With the exception of samples collected at sites WBLMP08 and WBLMP09, all pore-water samples collected in lake sediments of White Bear Lake had chloride concentrations higher than concentrations in surface-water samples from White Bear Lake (table 8). Background chloride concentrations in groundwater in glacial aquifers in Ramsey County range between 14 and $43 \mathrm{mg} / \mathrm{L}$ (Kanivetsky and Cleland, 1992). Concentrations in 7 of 10 pore-water samples from White Bear Lake sediments were higher than background chloride concentrations.

Oxygen-18/oxygen-16 and deuterium/protium ratios for all the pore-water samples collected from White Bear Lake except for samples from site WBLMP10 were lower than ratios for the surface-water samples for the lake (table 9) and plotted relatively close to the meteoric water line (fig. 13D). With the exception of the sample from site WBLMP10, oxygen-18/oxygen-16 ratios for pore-water samples ranged from -11.0 to -8.4 per mil (fig. $13 D$ ); deuterium/protium ratios ranged from -78.4 to -59.1 per mil (table 9). Oxygen-18/ oxygen-16 and deuterium/protium ratios for site WBLMP10 
were -2.0 and -25.7 , respectively, which were more similar to the surface-water ratios than the other pore-water ratios (fig. 13D). These ratios indicated little groundwater was entering the lake at site WBLMP10, and either lake water is discharging to aquifers at the site or some lake water may have leaked into the lake sediments during sampling. Groundwater was likely flowing into the lake at all the pore-water sample sites except site WBLMP10 because (1) the ratios for all the pore-water samples except the sample from site WBLMP10 plotted relatively close to the meteoric water line, and (2) the ratios for all the pore-water samples except the sample from site WBLMP10 were not similar to ratios for water samples collected from White Bear Lake (fig. 13D). Oxygen-18/ oxygen-16 and deuterium/protium ratios for three pore-water samples (sites WBLMP03, WBLMP05, and WBLMP11) were much lower than the ratios for the other pore-water samples (fig. 13D). The low ratios for the three pore-water samples are closer to the ratios for the snow samples (fig. 13A) than ratios for the other pore-water samples. These ratios may indicate groundwater flowing into the lake at the three pore-water sites may have been recharged in early spring, and groundwater flowing into the lake at the other pore-water sites may have been recharged in late spring and early summer.

\section{Well-Water Quality}

Major constituent concentrations in groundwater from wells open to glacial, St. Peter, and Prairie du Chien-Jordan aquifers generally were higher than in the water samples collected from White Bear Lake (table 8). Concentrations of bicarbonate, carbon dioxide, iron, and manganese were higher in all the well-water samples than in the surface-water samples collected from White Bear Lake (table 8). Concentrations of calcium and magnesium in all but one of the wellwater samples were higher than in the surface-water samples. Specific conductance and alkalinity values also were higher in all the well-water samples than in the surface-water samples (table 8). Dissolved oxygen concentrations were less than $3.0 \mathrm{mg} / \mathrm{L}$ in all the well-water samples; concentrations were less than $0.5 \mathrm{mg} / \mathrm{L}$ in seven of the eight well-water samples (table 8). The three highest concentrations of dissolved iron in well-water samples were from wells screened in the glacial aquifers. As previously mentioned, high iron concentrations are typical in the Superior lobe tills present in Quaternary sediments in the White Bear Lake area (Swanson and Meyer, 1990; Lively and Thorleifson, 2009).

Percentage differences in the ionic balances were less than \pm 5 percent for all but one of the well-water samples collected near White Bear Lake (table 8), indicating the major constituents were in good balance for all but one of the samples. The well-water sample collected from a MDNR observation well extracting water from a glacial buried aquifer (GLA-4) had a difference of 6.1 percent. Concentrations of calcium, magnesium, and bicarbonate were lower and concentrations of carbon dioxide, potassium, and sodium were higher in this well-water sample than concentrations in all the other well-water samples (table 8). The concentrations of calcium and magnesium in the sample from well GLA-4 were more similar to concentrations in surface-water samples collected from White Bear Lake than in the other well-water samples (table 8). These concentrations indicate water from well GLA-4 might be a mixture of surface water and groundwater or water in the well was not hydraulically connected with or isolated from surrounding groundwater.

Oxygen-18/oxygen-16 and deuterium/protium ratios for the water samples collected from wells open to glacial buried, St. Peter, or Prairie du Chien-Jordan (including wells only open to either the Prairie du Chien or Jordan) aquifers around White Bear Lake varied widely, from near the meteoric water line to near ratios for the surface-water samples for White Bear Lake (fig. 13C). The largest ranges in oxygen-18/ oxygen-16 and deuterium/protium ratios were for wells completed in the glacial buried or Prairie du Chien-Jordan aquifer (table 9). These ratios plotted linearly between the meteoric water line and the surface-water samples for White Bear Lake (fig. 13C). Oxygen-18/oxygen-16 ratios for the water samples collected from wells screened in the glacial buried aquifer ranged from -9.1 to -3.6 per mil (fig. $13 C$ ), and deuterium/ protium ratios ranged from -63.5 to -34.0 per mil (table 9 ). Oxygen-18/oxygen-16 ratios for the water samples collected from wells screened in the Prairie du Chien-Jordan aquifer ranged from -8.5 to -3.8 per mil (fig. $13 C$ ), and deuterium/protium ratios ranged from -62.2 to -35.0 per mil (table 9 ). Small differences were measured in the oxygen-18/oxygen-16 ratios for the water samples collected from the two wells open to the St. Peter aquifer, plotting relatively close to the meteoric water line (fig. 13C). Oxygen-18/oxygen-16 ratios for water from these two wells ranged from -8.5 to -8.4 per mil (fig. $13 C$ ), and deuterium/protium ratios ranged from -62.2 to -59.3 per mil (table 9).

The wide range in oxygen-18/oxygen-16 and deuterium/ protium ratios for water sampled from wells completed in the glacial buried aquifer or the Prairie du Chien-Jordan aquifer indicates different sources are supplying these wells with water. Well water with oxygen-18/oxygen-16 and deuterium/ protium ratios that are near the meteoric water line (wells GLA1, GLA-4, PDC-1, and PDCJ-3) consist mostly of groundwater that was recharged relatively quickly following rainfall events, having little time to be affected by evaporation. Well water with oxygen-18/oxygen-16 and deuterium/protium ratios between the meteoric water line and ratios for the surface-water samples for White Bear Lake consists of a mixture of surface water and groundwater; the percentage of each source varies relative to its ratios. Water from three of the five wells that obtain water from glacial buried aquifers and five of the seven wells that obtain water from Prairie du Chien-Jordan aquifer had oxygen-18/oxygen-16 and deuterium/protium ratios that indicated the well water was a mixture of surface water and groundwater (fig. 13C; table 9).

White Bear Lake is the likely source of the surface water to the wells with a mixture of surface water and groundwater because (1) it is the only large, deep lake near these wells, 
(2) these wells are located near and downgradient from White Bear Lake, and (3) these wells obtain their water from relatively deep depths. Wells with a mixture of surface water and groundwater and open to glacial buried aquifers were less than $0.5 \mathrm{mi}$ from White Bear Lake. These wells were screened in the glacial buried aquifer at depths ranging from 101 to $132 \mathrm{ft}$ below the land surface. The five wells with a mixture of surface water and groundwater and open to Prairie $\mathrm{du}$ Chien-Jordan aquifer were at depths ranging from 178 to $470 \mathrm{ft}$ below the land surface and less than $1.5 \mathrm{mi}$ south of White Bear Lake. Of these five wells, four of the wells were open to the aquifer at depths greater than $275 \mathrm{ft}$ below the land surface. Oxygen-18/oxygen-16 and deuterium/protium ratios for water from wells that were upgradient from White Bear Lake indicated the water was only from groundwater and not a mixture of groundwater and surface water.

The linear relation between the oxygen-18/oxygen-16 and deuterium/protium ratios for the well-water samples was used to develop a groundwater/lake-water isotope mixing model to estimate the percentage of surface-water contribution to the well water (fig. 16). Two end points were established for this relation: one point to represent 100 percent groundwater contribution and another point to represent 100 percent surface-water contribution (fig. 16). The average oxygen-18/ oxygen-16 and deuterium/protium ratios for the well-water samples near the meteoric water line were used for the 100 percent groundwater contribution end point. The average oxygen-18/oxygen-16 and deuterium/protium ratios for the surface-water samples for White Bear Lake were used for the 100 percent surface-water contribution end point. Using these end points, the percentage of surface-water contribution to the well water was estimated by comparing the linear distance of the oxygen-18/oxygen-16 and deuterium/protium ratios for the well-water sample from the two end points. Well-water samples with oxygen-18/oxygen-16 and deuterium/protium ratios closer to the average ratios for the surface-water samples had a larger estimated percentage of surface-water contribution; well-water samples with oxygen-18/oxygen-16 and deuterium/ protium ratios closer to the average ratios for the well-water samples near the meteoric water line had a smaller percentage of surface-water contribution.

The percentages of surface-water contribution to the three wells screened in the glacial buried aquifer (fig. 16, wells 2 , 3 , and 5) receiving surface water were 83,48 , and 16 percent. The largest percentage of surface-water contribution ( 83 percent) was for a well on Manitou Island (fig. 16) that extracts water from depths between 122 and $132 \mathrm{ft}$ below the land surface. The other two wells with surface-water contributions are between Bald Eagle Lake and White Bear Lake, downgradient from White Bear Lake, and extract water from depths greater than $100 \mathrm{ft}$ below the land surface.

The percentages of surface-water contribution ranged from 5 to 79 percent for the five wells open to the Prairie du Chien-Jordan aquifer receiving a mixture of groundwater and surface water (fig. 16, wells 9, 10, 11, 13, 14); the largest percentages of surface-water contribution were for wells closer to White Bear Lake. The largest percentage of surfacewater contribution (79 percent) was for a MDNR observation well at Bellaire Beach on the south shore of White Bear Lake (figs. 3 and 16). This well extracts water from depths between 178 and $194 \mathrm{ft}$ below the land surface. The smallest percentage of surface-water contribution (5 percent) was for the well farthest from White Bear Lake (approximately $1.5 \mathrm{mi}$ south of the lake) (fig. 16). This well may have had the lowest surfacewater contribution because the well was on the outer part of the Prairie du Chien-Jordan aquifer receiving surface water from White Bear Lake or far enough from the lake to receive more groundwater than the other wells receiving surface water.

\section{Near-Shore Hydraulic-Head Differences, Seepage Rates, and Lake-Sediment Characteristics}

Hydrologic data indicated groundwater inflow to White Bear Lake was from the northeast, east, southeast, and south shores from glacial aquifers. Hydraulic-head differences were measured at 19 of the 25 locations where seepage fluxes were measured (fig. 3; table 1-10) along the shore of White Bear Lake. These measurements indicated groundwater was flowing into most of the lake along the shoreline from shallow aquifers; the highest flow rates were on the east and southeast parts of the lake. Slumped sediment and $3.7 \mathrm{ft}$ of organic material were present in the lake core collected at one of the deepest locations in White Bear Lake.

\section{Mini-Piezometer/Seepage-Meter Surveys}

Hydraulic-head differences measured in August and September 2011 indicated groundwater was flowing into the lake along the shoreline from shallow aquifers at 12 of the 19 locations where seepage fluxes and hydraulic-head differences were measured. Hydraulic-head differences (hydraulic head of lake-sediment pore water minus hydraulic head of the lake) measured along the shoreline of White Bear Lake ranged from -0.02 to $0.09 \mathrm{ft}$ (fig. 15; table 1-10). Positive differences indicated the hydraulic head is higher in the lake sediments, with potential groundwater inflow to the lake, and negative differences indicated the lake level is higher, with potential lake water discharging into surrounding aquifers. Of the 19 sites where hydraulic-head differences were measured, hydraulic-head differences were positive at 12 sites, equal to zero at 3 sites, and negative at 4 sites (fig. 15; table 1-10). Positive hydraulic-head differences were measured at all locations along the east and southeast shore of the lake (fig. 15). Positive hydraulic-head differences also were measured along the southwest shore and at Ramsey County Beach (fig. 15). The highest positive hydraulic-head difference (0.09) was measured between Goose Lake and White Bear Lake. Negative hydraulic-head differences were measured along the north and northwest shore of the lake and at Bellaire Beach (fig. 15; 


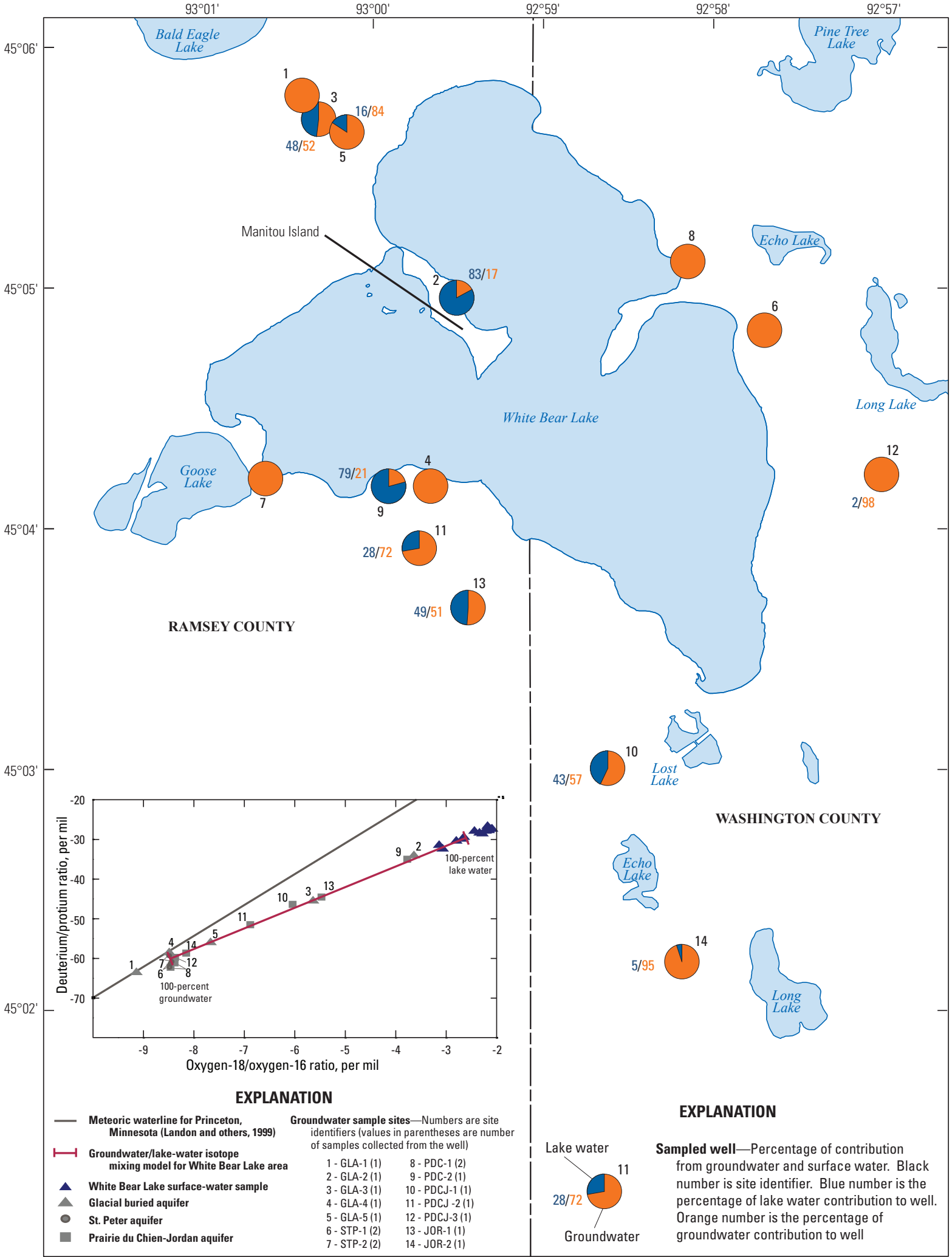

Base data from Minnesota Department of Natural Resources digital data, 1:24,000 and

U.S. Geological Survey, 1:100,000

Universal Transverse Mercator projection, Zone 15

Horizontal coordinate information is referenced to

the North American Datum of 1983 (NAD 83)

Figure 16. Oxygen-18/oxygen-16 ratios and deuterium/protium ratios and percentage contribution from groundwater and surface water for well-water samples near White Bear Lake, northeast Twin Cities Metropolitan Area, Minnesota. 
table 1-10), potentially indicating lake-water discharge along the shoreline to shallow aquifers at these locations. Hydraulic-head differences equal to zero were measured along the west and northwest shore and at Bellaire Beach (fig. 15; table 1-10), indicating minimal to no water movement in the lake sediments.

Positive median fluxes were measured at 10 locations along the northeast, east, northwest, southeast, and southwest shore of the lake (fig. 15). Hydraulic-head differences were positive at 9 of these 10 locations (table 1-10), indicating groundwater inflow to the lake at these locations. Median seepage-meter fluxes at the 25 locations along the shores of White Bear Lake ranged from -0.01 to 1.60 foot per day (ft/d) (table 1-10). Low positive median fluxes and slightly negative hydraulic-head differences were measured south of White Bear Beach Park (fig. 15), likely indicating minor groundwater inflow to the lake and minor lake-water discharge to aquifers at the location at different periods of time. Median fluxes greater than $0.18 \mathrm{ft} / \mathrm{d}$ were measured at five locations, two along the southeast shore and three along the east shore of the lake (fig. 15). Positive hydraulic-head differences were measured at these five locations (table 1-10). Low, negative median fluxes (less than $0.02 \mathrm{ft} / \mathrm{d}$ ) were measured in three of the six seepage meters installed at Bellaire Beach, one seepage meter installed in the southwest part of Manitou Island, and one seepage meter installed southeast of White Bear Beach Park (fig. 15, table 1-10). These low negative median fluxes indicate a small amount of water was discharging from the lake to local aquifers at these locations. Low, negative hydraulic-head differences were measured at Bellaire Beach and southeast of White Bear Beach Park, indicating potential lake-water discharge to shallow aquifers at these locations.

Values of vertical hydraulic conductivity determined from the non-zero hydraulic-head differences and median seepage-flux measurements ranged from 1.5 to $232 \mathrm{ft} / \mathrm{d}$ (table 1-10), with a median and an average of 2.9 and $15 \mathrm{ft} / \mathrm{d}$, respectively. These values are similar to typical values for sands (Domenico and Schwartz, 1990) but are much lower than the average horizontal hydraulic conductivity for the White Bear Lake used for Quaternary sediment in the Metro model (74.1 ft/d) (Metropolitan Council, 2012).

\section{Lake-Sediment Coring/Penetration Probe}

A relatively thin deposit of organic material with more permeable, slumped sands and gravels was found in the lakesediment core collected in the southeastern part of White Bear Lake (fig. 3). The lake core was $12.4 \mathrm{ft}$ long and was collected in five sections on March 16, 2011. It is likely the core did not completely collect the entire Holocene sequence of lake sediments because the length of the core was relatively short compared to cores collected from lakes of similar depth to White Bear Lake (Webb and Webb, 1988; Dean and Gorham, 1998). The lithology of the core was divided into 10 distinct units (table 10) on the basis of nomenclature outlined by Schnurrenberger and others (2003). The upper $2 \mathrm{ft}$ of the core consisted of very dark, massive organic material varying in color from dark gray to black (table 10). The sediment was dominated by centric diatoms, primarily Aulacoseira sp. A layer of fine sand to gravel-size clastics was present between 2.0 and $2.4 \mathrm{ft}$ in the core and likely was sediments slumped to the location. A mixture of organic-rich clay and clastics were present below the upper organic material between 2.4 and $3.7 \mathrm{ft}$. The organic-rich clays and clastics between 2.4 and $3.7 \mathrm{ft}$ were lighter in color than the organic material at the top of the core. Stephanodiscus sp. diatoms dominated the sediments in this interval.

Table 10. Lithology of lake-sediment core collected from White Bear Lake, northeast Twin Cities Metropolitan Area, Minnesota.

\begin{tabular}{|c|c|c|c|c|}
\hline \multirow{2}{*}{$\begin{array}{l}\text { Unit } \\
\text { mumber }\end{array}$} & \multicolumn{2}{|c|}{ Depth below lake bottom (feet) } & \multirow{2}{*}{ Color } & \multirow{2}{*}{ Unit lithology } \\
\hline & Top of unit & Bottom of unit & & \\
\hline 1 & 0 & 2.0 & Dark gray to black & $\begin{array}{l}\text { Massive, very dark, organic material, dominated by centric diatoms, } \\
\text { primarily Aulacoseira sp. }\end{array}$ \\
\hline 2 & 2.0 & 2.4 & Dark and light gray & $\begin{array}{l}\text { Sub-rounded, unsorted, fine sand to gravel; abrupt contacts with } \\
\text { above and below units. }\end{array}$ \\
\hline 3 & 2.4 & 3.7 & Dark gray to black & $\begin{array}{l}\text { Organic-rich clays and clastics, dominated by Stephanodiscus sp. } \\
\text { diatoms. }\end{array}$ \\
\hline 4 & 3.7 & 7.6 & Gray to pink & Thin layers of clay and coarse silt, small black bands common. \\
\hline 5 & 7.6 & 9.1 & Light tan & $\begin{array}{l}\text { Massive coarse silt with thin layer of very fine sand, diffuse contact } \\
\text { with above unit by increase in grain size. }\end{array}$ \\
\hline 6 & 9.1 & 9.5 & Tan & Massive fine sand. \\
\hline 7 & 9.5 & 9.9 & Tan & Fine sand to gravel; similar to unit 2. \\
\hline 10 & 11.1 & 12.4 & Tan & Massive coarse silt to fine sand. \\
\hline
\end{tabular}


Below the upper $3.7 \mathrm{ft}$ of the core were a series of fine to coarse sand and gravel layers separated by massive layers of silt and fine sand (table 10). Numerous thin layers of coarse silt and coarser clastics varying in color from gray to pink were present between 3.7 and $7.6 \mathrm{ft}$, with small black bands common. Sand and gravel layers present between 9.5 and $11.1 \mathrm{ft}$ (table 10) likely represent material that slumped to the location from shallower waters because (1) abrupt contacts were present above and below the units, (2) the core was collected in proximity to the base of a steep slope, and (3) larger, sub-rounded grains and unsorted material were present in these layers. Light tan to tan, massive layers of fine sand or coarse silt with very fine sand were present between 7.6 and $9.5 \mathrm{ft}$ and between 11.1 and $12.4 \mathrm{ft}$ in the core (table 10) and likely were slumped to the location or represent periods of lower water levels in the lake and not glacial in origin.

Penetration-probe measurements ranged from $0 \mathrm{ft}$ near the east shore of the lake to $15 \mathrm{ft}$ approximately $500 \mathrm{ft}$ from the south shore of the lake (fig. 3; table 11). The greatest penetration-probe depths were from approximately 530 to $2,610 \mathrm{ft}$ from the south shore of the lake (table 11). A notable, shallow penetration-probe depth (only $1.5 \mathrm{ft}$ ) occurred at a distance of 3,500 ft from the south shore of the lake (table 11). At the core location (site 6), the penetration probe depth was $7 \mathrm{ft}$, which indicated the probe went through organic material, clay, and slumped sands and gravels (tables 10 and 11). The penetration-probe measurements at the core site may indicate the penetration probe measurements are overestimating the thicknesses of the organic material in the lake.

A lack of thick deposits of organic material and the presence of more permeable, slumped sands and gravels in the lake-sediment core collected in White Bear Lake indicate the lakebed may be more permeable in the deep waters. Minnesota lakes that have persisted for the entire Holocene typically will have approximately 23 to $46 \mathrm{ft}$ ( 7 to $14 \mathrm{~m}$ ) of lake sediments (Webb and Webb, 1988; Dean and Gorham, 1998). The entire length of the White Bear Lake core was only $12.4 \mathrm{ft}$. However, the lake core may not have collected a full record of the Holocene lake sediments, not reaching the Pleistocene glacial sediments. If this is true, additional organic material may be present below the slumped material and massive silt and fine sand, potentially reducing vertical flow between the lake and underlying aquifers. The presence of permeable sands and gravels allows for a hydraulic connection to shallow and deep aquifers. Slumping of sediments tends to create conditions that are more permeable vertically when compared to areas of non-slumping sediments that are flat lying. Slumped sediments in the lake core from White Bear Lake likely indicate sediment movement from shallower water locations to the deeper, coring location. Penetration-probe measurements indicate the maximum potential thicknesses of organic material at the probe locations would be $15 \mathrm{ft}(4.5 \mathrm{~m})$, which is low compared to most Minnesota lakes. However, similar to the lake core, the penetration probes may not have reached the bottom of the lake sediments.

Physical characteristics of White Bear Lake might explain the lack of thick organic lake sediments at deeper depths. Large lakes that receive allocthonous materials, such as slumped sands and gravels, tend to have less organic material per lakebed area compared to smaller lakes (Edward G. Stets, U.S. Geological Survey, written commun., May 17, 2012). Lakes with small watersheds, such as White Bear Lake, tend to have lower rates of sediment accumulation than lakes with larger watersheds. Deeper parts of lakes do not accumulate organic material from macrophytes because they do not tend to exist at depths more than $20 \mathrm{ft}$ below the water surface. Although deeper parts of the lake may not be accumulating organic matter from macrophytes, preservation of autochthonous organic material may be better at the deeper parts of the lake if the bottom waters are anoxic.

Table 11. Penetration-probe measurements for lake sediments from White Bear Lake, northeast Twin Cities Metropolitan Area, Minnesota.

[ft, feet; BWS, below water surface; ft BLB, below lake bottom]

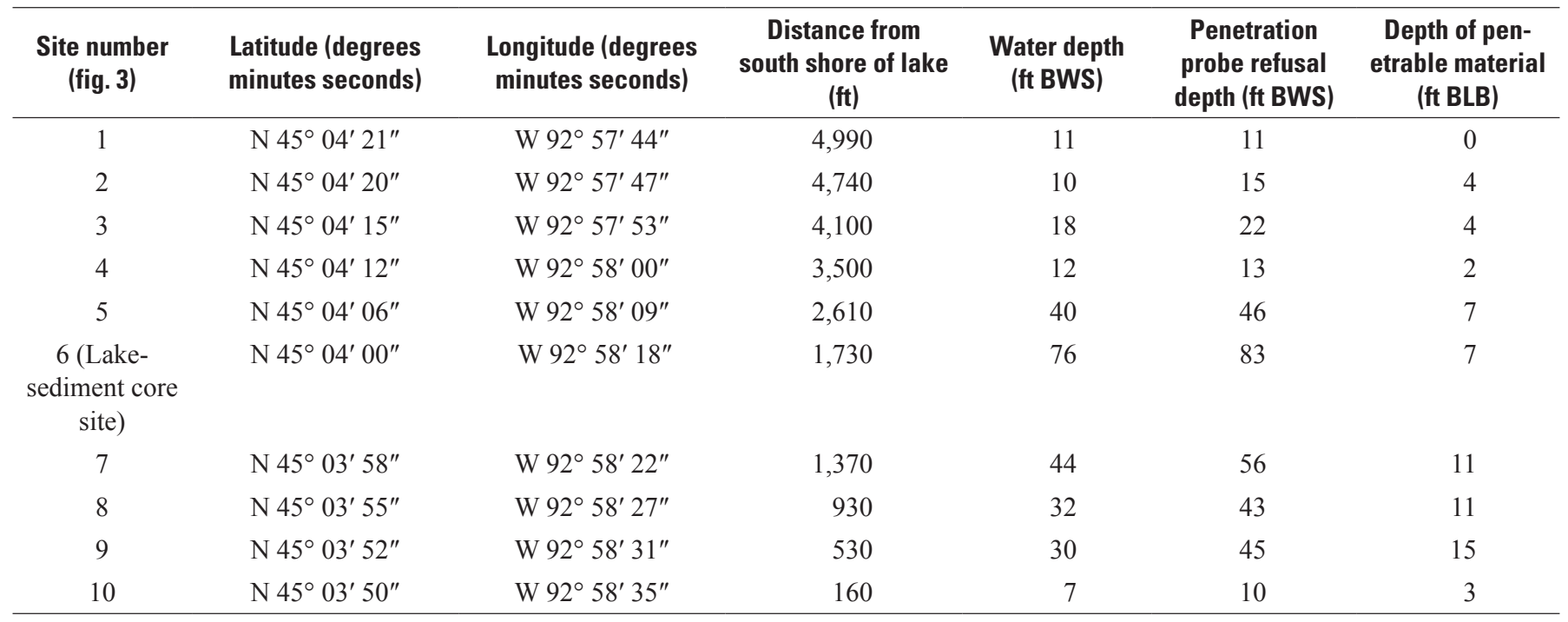




\section{Water Balance for March and August 2011}

Estimates from monthly water balances for White Bear Lake for March and August 2011 indicate groundwater inflow is a main component in the lake water balance, particularly in March, and seasonal differences exist in the amounts of lake water discharging from the lake and entering deeper aquifers. Groundwater inflows to the lake were fairly consistent; monthly volumes only varied by 0.3 in. between March and August 2011.

Monthly estimates for water-balance components (fig. 6) varied widely for White Bear Lake for March and August 2011 (table 12). Total water inflows to the lake for March and August 2011 were 950 and 1,850 acre-feet, respectively, or 4.7 and 9.2 in., respectively, over the area of the lake (table 12). Total water outflows from the lake for March and August 2011 were 11 and 1,011 acre-feet, respectively, or 0.1 and 5.0 in., respectively, over the area of the lake (table 12). In March 2011, water inflow to the lake was from precipitation and groundwater inflow, and water discharge from the lake was to aquifers surrounding the lake. Precipitation falling on the lake surface was the major contributor to the lake in March and August (table 12). In August 2011, the amount of groundwater inflow to the lake from water-table aquifers was similar to the amount of surface-water runoff entering the lake (table 12). For both months, the difference between groundwater inflow from and lake-water discharge to water-table aquifers was approximately 2.0 in. over the area of the lake. Evaporation from the lake surface was the major outflow from the lake in August (table 12).

Comparing the water balances for August and March 2011 for White Bear Lake showed a summer increase in lake-water discharge. The difference between total inflow, total outflow, and change in lake-water volume for March and August 2011 were 579 and 904 acre-feet, respectively, or 2.8 and 4.5 in., respectively, over the area of the lake (table 12). Monthly differences represent the sum of the amount of lake-water discharge to deep glacial and bedrock aquifers and data measurement and estimation errors. The total differences between total inflow, total outflow, and change in lake-water volume in March and August 2011 (2.8 and 4.5 in.) were more than three times the potential errors ( 0.5 and 1.4 , respectively) (table 12). Subtracting and adding the potential error from the total difference between total inflow, total outflow, and change in lake-water volume, the estimated amount of lake-water discharge to deeper glacial and bedrock aquifers in March and August would range from 2.3 to $3.3 \mathrm{in}$. and from 3.1 to $5.9 \mathrm{in}$., respectively, from White Bear Lake. Applying the leakage equation and hydraulic parameters from Larson-Higdem and others (1975) for the Prairie du Chien-Jordan aquifer below White Bear Lake, average monthly leakage from White Bear Lake to glacial and Prairie du Chien-Jordan aquifers was approximately 2.3 in., which is similar to the March 2011 value (2.8 in.).

The summer increase in lake-water discharge could be related to lower groundwater levels and larger groundwater withdrawals in the Prairie du Chien-Jordan aquifer. Large summer groundwater withdrawals have caused groundwater levels to decline in the Prairie du Chien-Jordan aquifer, increasing vertical hydraulic gradients and lake-water discharge from White Bear Lake. This increase in lake-water discharge from White Bear Lake has resulted in a lower mean lake stage (elevation). Lower groundwater levels in the Prairie du Chien-Jordan aquifer near White Bear Lake (figs. 1 and 8), particularly in the summer, create a condition for increased discharge of lake water to deep aquifers. The lower lake-water

Table 12. Monthly water balance for March and August 2011 for White Bear Lake, northeast Twin Cities Metropolitan Area, Minnesota.

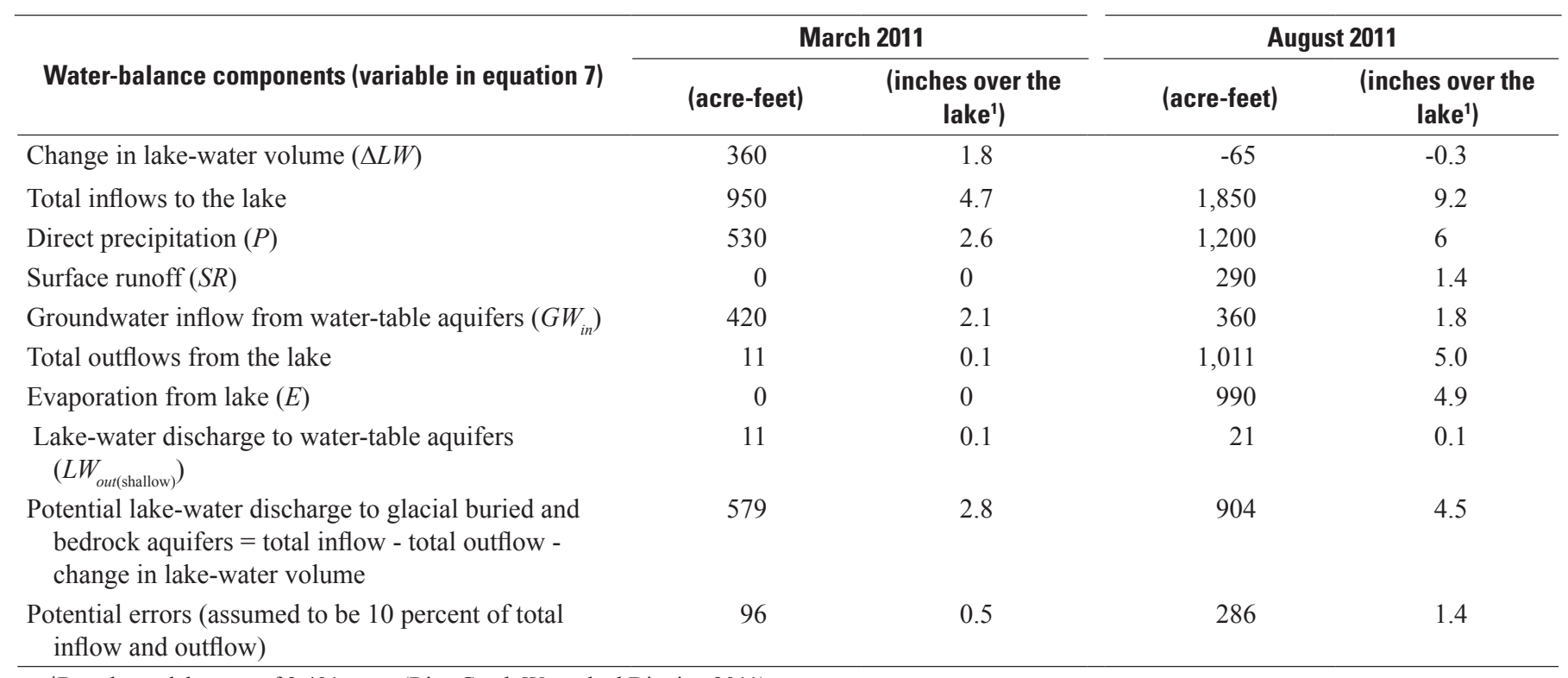

${ }^{1}$ Based on a lake area of 2,401 acres (Rice Creek Watershed District, 2011). 
discharges in March 2011 correlated with high groundwater levels in observation wells open to the Prairie du Chien-Jordan aquifer during March. Groundwater withdrawals from the Prairie du Chien-Jordan aquifer are not a direct measure of any lake-water discharge from White Bear Lake to the aquifer but certainly affects the amount of lake-water discharge to aquifers.

\section{Implications of Groundwater and Surface-Water Interactions}

Water-level and water-quality data indicate water from the lake flows vertically into the underlying aquifers. In both groundwater synoptic surveys, water levels for White Bear Lake were approximately $10 \mathrm{ft}$ higher than groundwater levels in wells open to the Prairie du Chien-Jordan aquifer near the lake, indicating the potential for lake-water discharge to the aquifer. Setterholm (1991) recorded a similar vertical waterlevel difference. Oxygen-18/oxygen-16 and deuterium/protium ratios for water from wells open to the Prairie du Chien-Jordan aquifer south and downgradient from White Bear Lake and some wells screened in glacial aquifers between White Bear Lake and Bald Eagle Lake indicate the presence of a mixture of surface water and groundwater. White Bear Lake likely is the source of the surface water to the wells with a mixture of surface water and groundwater because (1) it is the only large, deep lake near these wells, (2) these wells are near and downgradient from White Bear Lake, and (3) these wells get their water from relatively deep depths. Some of these wells are used for public supply by municipalities near White Bear Lake.

The presence of surface water in wells near White Bear Lake can affect the protection and treatment of water for these public water supplies. Communities in Minnesota and throughout the United States are required to develop and implement wellhead protection plans that safeguard their water sources from contamination (Minnesota Department of Health, 2012). As part of these plans, source-water protection areas must be delineated for each water source. The delineation of a source-water protection area around a public-supply well that withdraws water from aquifers with a mixture of groundwater and surface water should include the source area for the groundwater and the watershed for the surface-water source (U.S. Environmental Protection Agency, 1997). The source areas would be the zone of transport for the well, which may include parts of the aquifer where groundwater is being withdrawn, other aquifers between the lake bottom and the aquifer where groundwater is being withdrawn, and the watershed for the surface-water source. Source-water protection areas for wells withdrawing a mixture of surface water and groundwater typically are larger than for wells that withdraw only groundwater from the same aquifer at similar groundwater volumes. Public-supply wells with a mixture of groundwater and lake water from White Bear Lake may need to include the lake watershed in their source-water protection areas. Commonly, the watershed of a lake may be part of source-water protection areas for multiple public-supply wells, potentially serving multiple communities. For example, municipal wells from the cities of Bovey and Coleraine, Minnesota, likely receive water from the upgradient Canisteo Mine Pit Lake (Jones, 2002; Walsh, 2007). Groundwater flow modeling and isotopic analysis of water from several municipal wells for the cities of Mora, Long Prairie, and Baxter, Minnesota, indicate a direct influence of a lake on water to these wells (Short Elliott Hendrickson Inc., 2012; James F. Walsh, Minnesota Department of Health, written commun., December 5, 2012). In addition, water obtained from public-supply wells that extract a mixture of surface water and groundwater may be at risk of contamination from pathogens and viruses not typically found in groundwater (Oregon Health Authority, 2012). This water can be classified as groundwater under the direct influence of surface water. If classified as such in Minnesota, the well water would need to follow water-treatment practices used for surface waters (Minnesota Office of the Revisor of Statutes, 2012). Because of the potential risk for pathogens and viruses, water-treatment costs are higher for surface water and groundwater under the direct influence of surface water than for groundwater used for drinking water (U.S. Environmental Protection Agency, 2005).

Dissolution features commonly present in the Prairie du Chien-Jordan aquifer underlying White Bear Lake could affect the amount of water discharging from the lake to aquifers, even with glacial sediments lying between the lake bottom and the aquifer. Dissolution features, such as cavities, channels, caves, and sinkholes sometimes associated with fractures, have been identified in the Prairie du Chien Group throughout east-central and southeastern Minnesota (Runkel, Tipping, Alexander, and others, 2003). The presence of slumped material in the lake core collected in White Bear Lake and the deeper, circular bathymetric contours in White Bear Lake thought to be above the bedrock valley where the Prairie du Chien Group is the uppermost bedrock (Swanson and Meyer, 1990) suggest the potential for slumping of lakebed material and glacial sediments into developing or expanding solution features below the lake. Continued dissolution enlarges these karst features with time (Runkel, Tipping, Alexander, and others, 2003), potentially increasing the hydrologic connection of the lake to the aquifer and increasing lake-water discharge from the lake. The production of anoxic, low $\mathrm{pH}$ waters during hydrogen metabolism in lake sediments could increase dissolution, potentially increasing lake-water discharge over time (Conrad and others, 1987; Edward G. Stets, U.S. Geological Survey, written commun., May 17, 2012). Low dissolved oxygen concentrations and $\mathrm{pH}$ values were measured in the water-quality survey in the deepest part of White Bear Lake where the Prairie du Chien Group is thought to be the uppermost bedrock (figs. 3 and 4; Swanson and Meyer, 1990).

Historical precipitation and lake-level data indicate the lake levels in White Bear Lake and other northeast TCMA lakes will not recover unless the area receives abundant 
precipitation or changes water-use and management practices. Potential changes in water-use and management practices involve either increasing the amount of water inputs to the lake or reducing the amount of water discharging from the lake to underlying aquifers. Increasing the amount of water inputs to the lake could include bringing surface water or groundwater from outside the watershed or groundwater watershed. Water imported to the watershed could be pumped directly into the lake or could be used as a source of municipal drinking water, reducing municipal groundwater withdrawals from the Prairie $\mathrm{du}$ Chien-Jordan aquifer and, therefore, reducing lake-water discharge to the aquifer. Importing or diverting surface water from outside the lake watershed may require water treatment. The amount of groundwater withdrawals from the Prairie du Chien-Jordan aquifer could be reduced by (1) reducing water withdrawals from wells that have the greatest effect on lakewater discharge to aquifers, (2) implementing or increasing water-conservation practices, (3) using surface-water sources for municipal use instead of groundwater, and (4) treating and discharging wastewater within the watershed. Identifying and limiting groundwater withdrawals from wells that have the greatest effects on lake-water discharge from White Bear Lake may be done through the application of groundwater flow models and by working directly with municipal water managers to understand their water-use needs and issues. By limiting groundwater withdrawals from wells that have the greatest effect on lake-water discharge to aquifers, groundwater levels in the Prairie du Chien-Jordan aquifer may rise locally, reducing the amount of lake-water discharging to the aquifer. Wastewater from many communities in the northeast TCMA, including the cities of White Bear Lake, Forest Lake, and Hugo (fig. 1), is piped south to the Metropolitan Wastewater Treatment Plant in St. Paul, Minnesota. Treated water from this plant is discharged to the Mississippi River. Treated water from a local wastewater treatment plant within the White Bear Lake watershed could be discharged into infiltration basins upgradient from the lake or directly into the lake, keeping the water within the watershed.

\section{Summary}

The U.S. Geological Survey (USGS), in cooperation with the White Bear Lake Conservation District, the Minnesota Pollution Control Agency, the Minnesota Department of Natural Resources, and other State, county, municipal, and regional planning agencies, watershed organizations, and private organizations, applied a series of hydrologic and water-quality techniques to characterize groundwater and surface-water interactions near White Bear Lake through 2011. During 2010 and 2011, White Bear Lake and other lakes in the northeastern part of the TCMA were at historically low levels. Previous periods of lower water levels in White Bear Lake correlate with periods of lower precipitation; however, recent urban expansion and increased pumping from the Prairie du Chien-Jordan aquifer have put into question whether a decline in precipitation is the primary cause for the recent water-level decline in White Bear Lake. Understanding and quantifying the amount of groundwater inflow to a lake and water discharge from a lake to aquifers is commonly difficult but is important in the management of lake levels. Three methods were used to assess groundwater and surface-water interactions on White Bear Lake: (1) a historical assessment (1978-2011) of levels in White Bear Lake, local groundwater levels, and their relation to historical precipitation and groundwater withdrawals in the White Bear Lake area; (2) recent (2010-11) hydrologic and water-quality data collected from White Bear Lake, other lakes, and wells; and (3) water-balance assessments for White Bear Lake in March and August 2011.

An analysis of covariance between average annual lake-level change and annual precipitation indicated the relation between the two variables was significantly different from 2003 through 2011 compared with 1978 through 2002, requiring an average of 4 more inches of precipitation per year to maintain the lake level. This shift in the linear relation between annual lake-level change and annual precipitation indicated the net effect of the non-precipitation terms on the water balance has changed relative to precipitation. The average amount of precipitation required each year to maintain the lake level has increased from 33 inches per year during 1978-2002 to 37 inches per year during 2003-11. The analysis of covariance of both periods (1978-2002 and 2003-11) using the annual lake-level change, annual precipitation, annual surface outflow, and annual evaporation data indicated the decrease in volume in White Bear Lake between 2003 and 2010 was not explained by surface outflow or evaporation.

The combination of lower precipitation and an increase in groundwater withdrawals can explain the change in the lake-level response to precipitation. Annual and summer groundwater withdrawals from the Prairie du Chien-Jordan aquifer have more than doubled from 1980 through 2010. Results from a regression model constructed with annual lake-level change, annual precipitation minus evaporation, and annual volume of groundwater withdrawn from the Prairie du Chien-Jordan aquifer indicated groundwater withdrawals had a greater effect than precipitation minus evaporation on water levels in the White Bear Lake area for all years since 2003. The recent (2003-11) decline in White Bear Lake reflects the declining water levels in the Prairie du Chien-Jordan aquifer; increases in groundwater withdrawals from this aquifer are a likely cause for declines in groundwater levels and lake levels. Annual pumping from the Prairie du Chien-Jordan aquifer has more than doubled from 1980 through 2010, increasing from a minimum of 1,873 million gallons in 1980 to a maximum of 4,557 million gallons in 2007. The increase in the annual groundwater withdrawals from the Prairie du Chien-Jordan aquifer was due mainly to increases in summer withdrawals and, to a minor extent, increases in spring, fall, and winter withdrawals. 
Synoptic, static groundwater-level and lake-level measurements in March/April and August 2011 indicated groundwater was potentially flowing into White Bear Lake from glacial aquifers to the northeast and south, and lake water was potentially discharging from White Bear Lake to the underlying glacial and Prairie du Chien-Jordan aquifers and glacial aquifers to the northwest. Groundwater levels in the Prairie du Chien-Jordan aquifer below White Bear Lake are approximately 0 to 19 feet lower than surface-water levels in the lake, indicating groundwater from the aquifer likely does not flow into White Bear Lake, but lake water may discharge into the aquifer. Groundwater levels from March/April to August 2011 declined more than 10 feet in the Prairie du Chien-Jordan aquifer south of White Bear Lake and to the north in Hugo, Minnesota.

Water-quality analyses of pore water from nearshore lake-sediment and well-water samples, seepage-meter measurements, and hydraulic-head differences measured in White Bear Lake also indicated groundwater was potentially flowing into White Bear Lake from shallow glacial aquifers to the east and south. Negative temperature anomalies determined in shallow waters in the water-quality survey conducted in White Bear Lake indicated several shallow-water areas where groundwater may be flowing into the lake from glacial aquifers below the lake. Cool lake-sediment temperatures (less than 18 degrees Celsius) were measured in eight areas along the northeast, east, south, and southwest shores of White Bear Lake, indicating potential areas where groundwater may flow into the lake.

Stable isotope analyses of well-water, precipitation, and lake-water samples indicated wells downgradient from White Bear Lake screened in the glacial buried aquifer or open to the Prairie du Chien-Jordan aquifer receive a mixture of surface water and groundwater; the largest surface-water contributions are in wells closer to White Bear Lake. A wide range in oxygen-18/oxygen-16 and deuterium/protium ratios was measured in well-water samples, indicating different sources of water are supplying water to the wells. Well water with oxygen-18/ oxygen-16 and deuterium/protium ratios that plot close to the meteoric water line consisted mostly of groundwater because deuterium/protium ratios for most groundwater usually are similar to ratios for rainwater and snow, plotting close to meteoric water lines. Well water with oxygen-18/oxygen-16 and deuterium/protium ratios that plot between the meteoric water line and ratios for the surface-water samples from White Bear Lake consists of a mixture of surface water and groundwater; the percentage of each source varies relative to its ratios. White Bear Lake is the likely source of the surface water to the wells that have a mixture of surface water and groundwater because (1) it is the only large, deep lake near these wells; (2) these wells are near and downgradient from White Bear Lake; and (3) these wells obtain their water from relatively deep depths, and White Bear Lake is the deepest lake in that area.

The linear relation between the oxygen-18/oxygen-16 and deuterium/protium ratios for the well-water samples was used to estimate the percentage of surface-water contribution to the well water. The percentages of surface-water contribution to the three wells screened in the glacial buried aquifer receiving surface water were 16,48 , and 83 percent. The percentages of surface-water contribution ranged from 5 to 79 percent for the five wells open to the Prairie du Chien-Jordan aquifer receiving surface water; wells closest to White Bear Lake had the largest percentages of surface-water contribution.

A 12.4-foot lake core collected at the deepest part of White Bear Lake and penetration-probe measurements made across a transect in the southeast part of the lake indicated the amount of organic material was low compared to other Minnesota lakes. Most of the core consisted of silts, sands, and gravels likely slumped from shallower waters, with a very low amount of low-permeability, organic material. Penetrationprobe measurements ranged from 0.2 foot near the east shore of the lake to 15 feet approximately 500 feet from the south shore of the lake.

Water-balance analysis of White Bear Lake in March and August 2011 indicated a potential discharge of 2.8 and 4.5 inches per month, respectively, over the area of the lake from the lake to local aquifers. Total water inflows to the lake for March and August 2011 were 4.7 and 9.2 in., respectively, and total water discharges from the lake were 0.1 and $5.0 \mathrm{in.}$., respectively, over the area of the lake.

\section{References Cited}

Alexander, S., Setterholm, D., Tipping, R., and Meyer, G., 2001, The influence of ground water on the quality of lakes in the Carnelian-Marine watershed district: Minnesota Geological Survey, CD ROM, 33 p.

Almendinger, J.E., 1990, Groundwater control of closed-basin lake levels under steady-state conditions: Journal of Hydrology, v. 112, no. 3-4, p. 293-318. (Also available at http:// dx.doi.org/10.1016/0022-1694(90)90020-X.)

American Society of Civil Engineers, 1996, Hydrology handbook ( $2 \mathrm{~d}$ ed.): American Society of Civil Engineers Manuals and Reports on Engineering Practice No. 28, 784 p.

Andrews, W.J., Trotta, L.C., and Schoenberg, M.E., 1995, Water-level declines from 1980-90 in major aquifers in the Twin Cities area: Proceedings of the 31st Annual Conference and Symposia of the American Water Resources Association, Houston, Texas, November 5-9, 1995, p. 63-72.

Attanayake, M.P., and Waller, D.H., 1988, Use of seepage meters in a groundwater-lake interaction study in a fractured rock basin-A case study: Canadian Journal of Civil Engineering, v. 15 , no. 6, p. 984-989. (Also available at $h t t p: / /$ dx.doi.org/10.1139/188-130.)

Baker, D.G., and Kuehnast, E.L., 1978, Precipitation normals for Minnesota-1941-1970: Climate of Minnesota, Part X, University of Minnesota Agricultural Experiment Station, Technical Bulletin 314, $16 \mathrm{p}$. 
Barr Engineering, 2010, Evaluation of groundwater and surface-water interaction - Guidance for resource assessment: Twin Cities Metropolitan Area, Minnesota, prepared for Metropolitan Council, $22 \mathrm{p}$.

Brown, R.G., 1985, Hydrologic factors affecting lake-level fluctuations in Big Marine Lake, Washington County, Minnesota: U.S. Geological Survey Water-Resources Investigations Report 85-4176, 23 p. (Also available at $h t t p: / / p u b s$. usgs.gov/wri/1985/4176/report.pdf.)

Brown, R.G., 1986, Errors in estimating ground-water components of hydrologic and phosphorus budgets of lakes, in Subitzky, Seymour, ed., Selected papers in the hydrologic sciences, 1986: U.S. Geological Survey Water-Supply Paper 2310, p. 53-64.

Childress, C.J.O., Forman, W.T., Connor, B.F., and Maloney, T.J., 1999, New reporting procedures based on longterm method detection levels and some considerations for interpretations of water quality data provided by the U.S. Geological Survey National Water Quality Laboratory: U.S. Geological Survey Open-File Report 99-193, 19 p.

Coates, P.N., 1924, Special report on lake improvement: Ramsey County, Minnesota, Board of County Commissioners, $110 \mathrm{p}$.

Conrad, Ralf, Lupton, F.S., and Zeikus, J.G., 1987, Hydrogen metabolism and sulfate-dependent inhibition of methanogenesis in a eutrophic lake sediment (Lake Mendota): FEMS Microbiology Letters, v. 45, no. 2, p. 107-115. (Also available at $h t t p: / / d x . d o i . o r g / 10.1111 / j .1574-6968.1987$. tb02346.x.)

Dean, W.E., and Gorham, E., 1998, Magnitude and significance of carbon burial in lakes, reservoirs, and peatlands: Geology, v. 26, p. 535-538. (Also available at http:// digitalcommons.unl.edu/usgsstaffpub/299/)

Delin, G.N., 1991, Hydrogeology and simulation of groundwater flow in the Rochester area, southeast Minnesota, 1978-88: U.S. Geological Survey Water-Resources Investigations Report 90-4081, 102 p. (Also available at http://pubs.er.usgs.gov/publication/wri864321.)

Delin, G.N., and Woodward, D.G., 1984, Hydrogeologic setting and the potentiometric surfaces of the regional aquifers of the Hollandale Embayment, southeastern Minnesota, 1970-80: U.S. Geological Survey Water-Supply Paper 2219, 56 p.

Dincer, T., 1968, The use of oxygen 18 and deuterium concentrations in the water balance of lakes: Water Resources Research, v. 4, no. 6, p. 1,289-1,306. (Also available at http://dx.doi.org/10.1029/WR004i006p01289.)
Domenico, P.A., and Schwartz, F.W., 1990, Physical and chemical hydrogeology: New York, John Wiley and Sons, $824 \mathrm{p}$.

Donahower, Channing, 1994, White Bear Lake water level issues are nothing new: White Bear Press, article reprinted on November 11, 2010. (Also available at $h t t p: / / w w w$. presspubs.com/opinion/columnists/article_9711f1d2-53215125-a823-6e5858492376.html.)

Erickson, D.R., 1981, A study of littoral groundwater seepage at Williams Lake, Minnesota, using seepage meters and wells: Minneapolis, Minnesota, University of Minnesota, M.S. thesis, $153 \mathrm{p}$.

Fellows, C.R., and Brezonik, P.L., 1980, Seepage flow into Florida lakes: Journal of the American Water Resources Association, v. 16, no. 4, p. 635-641. (Also available at http://dx.doi.org/10.1111/j.1752-1688.1980.tb02442.x.)

Fishman, M.J., ed., 1993, Methods of analysis by the U.S. Geological Survey National Water Quality Laboratory-Determination of inorganic and organic constituents in water and fluvial sediments: U.S. Geological Survey Open-File Report 93-125, 217 p.

Gibson, J.J., and Edwards, T.W.D., 2002, Regional water balance trends and evaporation-transpiration partitioning from a stable isotope survey of lakes in northern Canada: Global Biogeochemical Cycles, v. 16, no. 2, p. $10-1$ to $10-14$. (Also available at $h t t p: / / d x$.doi. org/10.1029/2001GB001839.)

Gonfiantini, R., 1978, Standards for stable isotope measurements in natural compounds: Nature, v. 271, p. 534-536. (Also available at $h t t p: / / d x$.doi.org/10.1038/271534a0.)

Gons, H.J., 1999, Optical teledetection of chlorophyll a in turbid inland waters: Environmental Science and Technology, v. 33, p. 1,127-1,132. (Also available at $h t t p: / / d x . d o i$. org/10.1021/es9809657.)

Green, J.A., Luhmann, A.J., Peters, A.J., Runkel, A.C., Alexander, E.C., Jr., and Alexander, S.C., 2008, Dye tracing within the St. Lawrence confining unit in southeastern Minnesota, in Yuhr, L.B., Alexander, E.C., Jr., and Beck, B.F., eds., Sinkholes and the engineering and environmental impacts of karst: Reston, Va., American Society of Civil Engineers, Geotechnical Special Publication No. 183 , p. 477-484. (Also available at $h t t p: / / d x . d o i$. org/10.1061/41003(327)45.)

Green, J.A., Peters, A.J., Luhmann, A.J., Alexander, S.C., and Alexander, E.C., Jr., 2010, Karstic flow in the St. Lawrence confining unit: Proceedings from the 44th Annual NorthCentral Section and South-Central Joint Meeting, Branson, Missouri, Geological Society of America Abstracts with Programs, v. 42, no. 2, p. 108. 
Guswa, J.H., Seigel, D.I., and Gillies, D.C., 1982, Preliminary evaluation of the ground-water-flow system in the Twin Cities Metropolitan area, Minnesota: U.S. Geological Survey Water-Resources Investigations Report 82-44, 71 p.

Helsel, D.R., and Hirsch, R.M., 2002, Statistical methods in water resources: U.S. Geological Survey Techniques of Water Resources Investigations, book 4, chapter A3, 522 p.

Hem, J.D., 1985, Study and interpretation of the chemical characteristics of natural water ( $3 \mathrm{~d}$ ed.): U.S. Geological Survey Water-Supply Paper 2254, 263 p., 3 pl.

Horn, M.A., 1983, Ground-water-use trends in the Twin Cities metropolitan area, Minnesota, 1880-1980: U.S. Geological Survey Water-Resources Investigations Report 83-4033, $37 \mathrm{p}$.

Horne, A.J., and Goldman, C.R., 1994, Limnology (2d ed.): New York, McGraw-Hill Co., 576 p.

Johnson, G.C., Toole, J.M., and Larson, N.G., 2007, Sensor corrections for Sea-Bird SBE-41CP and SBE-41 CTDs: Journal of Atmospheric and Oceanic Technology, v. 24, p. 1,117-1,129. (Also available at $h t t p: / / d x$.doi.org/10.1175/ JTECH2016.1.)

Joint Committee for Guides in Metrology, 2008, International vocabulary of metrology-Basic and general concepts and associated terms: International Organization for Standardization, Geneva, Guide 99-12:2007, p. 1-127, accessed January 15, 2013, at http://www.bipm.org/utils/common/ documents/jcgm/JCGM_200_2008.pdf.

Jones, P.M., 2002, Characterization of ground-water flow between the Canisteo Mine Pit and surrounding aquifers, Mesabi Iron Range, Minnesota: U.S. Geological Survey Water-Resources Investigations Report 02-4198, 30 p. (Also available at http://pubs.usgs.gov/wri/wri024198/.)

Jones, P.M., 2006, Ground-water/surface-water interaction in nearshore areas of three lakes on the Grand Portage Reservation, northeastern Minnesota, 2003-04: U.S. Geological Survey Scientific Investigations Report 2006-5034, 49 p. (Also available at http://pubs.usgs.gov/sir/2006/5034/.)

Kanivetsky, R., and Cleland, J.M., 1992, Geologic atlas of Ramsey County, Minnesota: Minnesota Geological Survey County Atlas C-7, plate 6, surficial hydrogeology.

Kelly, S.E., and Murdoch, L.C., 2003, Measuring the hydraulic conductivity of shallow submerged sediments: Ground Water, v. 41, no. 4, p. 431-439.

Kenoyer, G.J., and Bowser, C.J., 1992, Groundwater chemical evolution in a sandy silicate aquifer in northern Wisconsin-1. Patterns and rates of change: Water Resources Research, v. 28, no. 2, p. 579-589. (Also available at http:// dx.doi.org/10.1029/91WR02302.)
Krabbenhoft, D.P., and Anderson, M.P., 1986, Use of a numerical ground-water flow model for hypothesis testing: Ground Water, v. 24, no. 1, p. 49-55. (Also available at http://dx.doi.org/10.1111/j.1745-6584.1986.tb01458.x.)

Krabbenhoft, D.P., Bowser, C.J., Anderson, M.P., and Valley, J.W., 1990, Estimating groundwater exchange with lakes - 1. The stable isotope mass balance method: Water Resources Research, v. 26, no. 10, p. 2,445-2,453. (Also available at $h t t p: / / d x$.doi.org/10.1029/WR026i010p02445.)

Landon, M.K., Delin, G.N., Komor, S.C., and Regan, C.P., 2000, Relation of pathways and transit times of recharge water to nitrate concentrations using stable isotopes: Ground Water, v. 38, no. 3, p. 381-395. (Also available at http://dx.doi.org/10.1111/j.1745-6584.2000.tb00224.x.)

Larson-Higdem, D.C., Larson, S.P., and Norvitch, R.F., 1975, Configuration of the water table and distribution of downward leakage to the Prairie du Chien-Jordan aquifer in the Minneapolis-St. Paul metropolitan area, Minnesota: U.S. Geological Survey Open-File Report 75-342, 33 p. (Also available at http://pubs.usgs.gov/of/1975/0342/report. $p d f$.)

Lee, D.R., 1977, A device for measuring seepage flux in lakes and estuaries: Limnology and Oceanography, v. 22, no. 1, p. $140-147$.

Lee, D.R., and Cherry, J.A., 1978, A field exercise on groundwater flow using seepage meters and mini-piezometers: Journal of Geological Education, v. 27, p. 6-10.

Lively, R.S., and Thorleifson, L.H., 2009, Minnesota soil, till, and ground-water geochemical data: Minnesota Geological Survey Open File Report OFR-09-02, 19 p., 1 poster, 69 atlas pages, 8 digital tables, 1 geodatabase.

Marine on St. Croix Watershed Management Organization, 2002, Diagnostic feasibility study and implementation plan for Square Lake, Washington County, Minnesota: Clean Water Partnership Project Report, 191 p.

McComas, Steve, and Stuckert, Jo, 2006, White Bear Lake data summary and trend analysis through 2005: St. Paul, Minnesota, Blue Water Science, 38 p., accessed December 28, 2012, at http://www.wblcd.org/docs/wbl_trend_ analysis_R05_full.pdf.

McComas, Steve, and Stuckert, Jo, 2009, White Bear Lake aquatic plant surveys, 2009: St. Paul, Minn., Blue Water Science, 12 p., accessed December 28, 2012, at http://www. wblcd.org/docs/WBL_aquatic_plant_surveys_2009.pdf.

Metropolitan Council, 2004, Water demand and planning in the Twin Cities Metropolitan Area-An update to the longterm water supply plan: Publication no. 32-04-021, 26 p., accessed December 28, 2012, at http://metrocouncil.org/ Publications-Resources.asp $x$ ? Category $=\&$ Category $=60$. 
Metropolitan Council, 2012, Metro Model 2: St. Paul, Minnesota, accessed May 10, 2012, at http://metrocouncil.org/ Wastewater-Water/Planning/Water-Supply-Planning/MetroModel-2.aspx.

Meyer, G.N., and Swanson, L., 1992, Geologic atlas of Ramsey County, Minnesota: Minnesota Geological Survey County Atlas Series C-7, accessed January 19, 2012, at http://purl.umn.edu/58233.

Minnesota Climatology Working Group, 2011a, Closest station climate data retrieval: State Climatology Office, accessed December 31, 2011, at http://climate.umn.edu/ hidradius/radius.asp.

Minnesota Climatology Working Group, 2011b, St. Paul Campus Climatological Observatory (Cooperative station ID 21-8450-6) monthly pan evaporation: Department of Soil, Water, \& Climate, accessed December 19, 2011, at http:// climate.umn.edu/img/wxsta/pan-evaporation.htm.

Minnesota Climatology Working Group, 2012a, Wetland delineation precipitation data retrieval from a gridded database: State Climatology Office, accessed February 29, 2012, at http://climate.umn.edu/wetland/.

Minnesota Climatology Working Group, 2012b, Drought 2009: State Climatology Office, accessed February 8, 2012, at http://climate.umn.edu/doc/journal/ drought_2009_091103.htm.

Minnesota Department of Health, 2012, Wellhead protection: accessed June 19, 2012, at http://www.health.state.mn.us/ divs/eh/water/swp/whp/index.htm.

Minnesota Department of Health/Minnesota Geological Survey, 2011, County Well Index online: accessed March through December 2011, at http://www.health.state.mn.us/ divs/eh/cwi/.

Minnesota Department of Natural Resources, 1998, Lakeground water interaction study at White Bear Lake, Minnesota: Report to the Legislative Committee on Minnesota Resources, accessed March 8, 2011, at http://files.dnr.state. mn.us/publications/waters/wbl_98.pdf.

Minnesota Department of Natural Resources, 2005, Water conservation-Wise use and efficiency is everyone's responsibility: accessed November 30, 2012, at http://files. dnr.state.mn.us/waters/groundwater_section/sustainability/ conservation.pdf.

Minnesota Department of Natural Resources, 2011a, Lake levels - White Bear Lake: Presentations given at the Lake Level Forum hosted by the City of White Bear Lake, September 2, 2010, accessed March 9, 2011, at http://whitebearlake.govoffice2.com/index.asp? Type $=B_{-}$ $B A S I C \& S E C=\{273 B 90 A A-5480-41 A A-B B C 7-$ A61F9E6BA5A0\}.
Minnesota Department of Natural Resources, 2011b, Water use-Water Appropriations Permit Program: accessed December 15, 2011, at http://www.dnr.state.mn.us/waters/ watermgmt_section/appropriations/wateruse.html.

Minnesota Department of Natural Resources, 2011c, St. PaulBaldwin Plains and Moraines Subsection: accessed December 15, 2011, at http://www.dnr.state.mn.us/ecs/222Md/ index.html.

Minnesota Department of Natural Resources, 2011d, Ground water level data retrieval: State Climatology Office, accessed December 16, 2011, at http://climate.umn.edu/ ground_water_level/.

Minnesota Department of Natural Resources, 2012, LakeFinder: St. Paul, Minnesota, accessed June 20, 2012, at http://www.dnr.state.mn.us/lakefind/index.html.

Minnesota Department of Transportation, 2012, MnDOT CORS GPS Network: St. Paul, Minn., accessed July 6, 2012, at http://www.dot.state.mn.us/surveying/ CORS/CORS.html.

Minnesota Geospatial Information Office, 2013, USGS High Resolution Orthoimagery, Ramsey County, Minnesota,

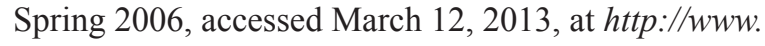
mngeo.state.mn.us/chouse/metadata/doq_ramsey06.html.

Minnesota Office of the Revisor of Statutes, 2012, Minnesota administrative rules - Rule 4720.3920 general requirements for construction of surface water and groundwater under the direct influence of surface water treatment facilities: St. Paul, Minn, accessed December 4, 2012, at https://www. revisor.mn.gov/rules/?id $=4720.3920$.

Minnesota Pollution Control Agency, 1999, Baseline WaterQuality of Minnesota's Principal Aquifers-Region 6, Twin Cities Metropolitan Area, accessed March 12, 2013, at http://www.pca.state.mn.us/index.php/view-document. html? gid $=6296$.

Minnesota Pollution Control Agency, 2008, Trichloroethylene monitoring results and swimming use health consultation: Minnesota Pollution Control Agency Water Quality/Surface Water Report \#1.25, 3 p., accessed December 28, 2012, at http://www.health.state.mn.us/divs/eh/hazardous/sites/ ramsey/longlakeinfo1208.pdf.

Minnesota Pollution Control Agency, 2011, White Bear Lake, Lake and stream water quality data: accessed December 15, 2011, at http://cf.pca.state.mn.us/water/ watershedweb/datasearch/waterUnit.cfm? wid=82-0167$00 \&$ tab $=$ Assesments.

Morey, G.B., 1972, Petrology of Keweenawan sandstones in the subsurface of southeastern Minnesota, in Sims, P.K., and Morey, G.B., eds., Geology of Minnesota-A centennial volume: Minnesota Geological Survey, p. 436-449. 
Mossler, J.H., 2008, Paleozoic stratigraphic nomenclature for Minnesota: Minnesota Geological Survey Report of Investigations $65,83 \mathrm{p} ., 1 \mathrm{pl}$.

Mossler, J.H., and Tipping, R.G., 2000, Bedrock geology and structure of the seven-county Twin Cities Metropolitan Area, Minnesota: Minnesota Geological Survey Miscellaneous Map Series M-104, 1 pl.

National Climatic Data Center, 2013, NOAA's 1981-2010 cli-

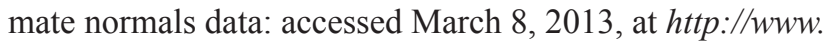
ncdc.noaa.gov/oa/climate/normals/usnormals.html.

Norvitch, R.F., Ross, T.G., and Brietkrietz, Alex, 1973, Water resources outlook for the Minneapolis-Saint Paul Metropolitan Area, Minnesota: U.S. Geological Survey Open-File Report 73-203, 219 p.

Oregon Health Authority, 2012, Groundwater under the direct influence of surface water: accessed December 4, 2012, at http://public.health.oregon.gov/ HEALTHYENVIRONMENTS/DRINKINGWATER/ SOURCEWATER/Pages/gwudi.aspx.

Pirkey, K.D., and Glodt, S.R, 1998, Quality control at the U.S. Geological Survey National Water Quality Laboratory: U.S. Geological Survey Fact Sheet FS-026-98, accessed July 6, 2012, at http://nwql.usgs.gov/FS-026-98.shtml.

Reeder, H.O., 1966, Fourteen maps of the hydrologic system, Minneapolis-St. Paul metropolitan area, Minnesota: U.S. Geological Survey Open-File Report 66-109, 14 pls.

Révész, Kinga, and Coplen, T.B., 2008, Determination of the $\delta\left({ }^{2} \mathrm{H} /{ }^{1} \mathrm{H}\right)$ of water-RSIL lab code 1574: U.S. Geological Survey Techniques and Methods 10-C1, $27 \mathrm{p}$.

Rice Creek Watershed District, 2011, White Bear Lake (82-0167) with watershed: accessed March 7, 2011, at http://www.ricecreekwatershed.govoffice2.com/ vertical/Sites/\%7BF68A5205-A996-4208-96B52C7263C03AA9\%7D/uploads/\%7BDEB1F0DB-2FB04E10-AAD2-261AA0D979FE\%7D.PDF.

Rosenberry, D.O., 1990, Effect of sensor error on interpretation of long-term water-level data: Ground Water, v. 28 no. 6 , p. $927-936$.

Rosenberry, D.O., and LaBaugh, J.W., eds., 2008, Field techniques for estimating water fluxes between surface water and ground water: U.S. Geological Survey Techniques and Methods 4-D2, 128 p. (Also available at http://pubs.usgs. gov/tm/04d02/.)

Rosenberry, D.O., Striegl, R.G., and Hudson, D.C., 2000, Plants as indicators of focused ground water discharge to a northern Minnesota lake: Ground Water, v. 38, no. 2, p. 296-303. (Also available at http://dx.doi. org/10.1111/j.1745-6584.2000.tb00340.x.)
Ruhl, J.F., 1994, Quality of ground water around Vadnais Lake and in Lambert Creek watershed, and interaction of ground water with Vadnais Lake, Ramsey County, Minnesota: U.S. Geological Survey Water-Resources Investigations Report 94-4062, 59 p. (Also available at http://pubs.usgs. gov/wri/1994/4062/report.pdf.)

Runkel, A.C., Tipping, R.G., Alexander, E.C., Jr., Green, J.A., Mossler, J.H., and Alexander, S.C., 2003, Hydrogeology of the Paleozoic bedrock in southeastern Minnesota: Minnesota Geological Survey Report of Investigations 61, 105 p., 2 pls.

Runkel, A.C., Tipping, R.G., and Mossler, J.H., 2003, Geology in support of groundwater management for the northwestern Twin Cities Metropolitan Area: Minnesota Geological Survey Open-File Report 08-4, accessed January 19, 2012, at $h t t p: / / p u r l . u m n . e d u / 108353$.

Runkel, A.C., Mossler, J.H., Tipping, R.G., and Bauer, E.J., 2006, A hydrogeologic and mapping investigation of the St. Lawrence Formation in the Twin Cities Metropolitan Area: Minnesota Geological Survey Open-File Report 06-04, 53 p., accessed January 19, 2012, at http:// purl.umn.edu/108892.

Sacks, L.A., 2002, Estimating ground-water inflow to lakes in central Florida using the isotope mass-balance approach: U.S. Geological Survey Water-Resources Investigations Report 2002-4192, 47 p.

Sanocki, C.A., Langer, S.K., and Menard, J.C. 2009, Potentiometric surfaces and changes in groundwater levels in selected bedrock aquifers in the Twin Cities Metropolitan Area, March-August 2008 and 1988-2008: U.S. Geological Survey Scientific Investigations Report 2009-5226, 67 p. with appendixes. (Also available at http://pubs.usgs.gov/ sir/2009/5226/.)

Schnurrenberger, D., Russell, J., and Kelts, K., 2003, Classification of lacustrine sediments based on sedimentary components: Journal of Paleolimnology, v. 29, no. 2, p. 141-154.

Schoenberg, M.E., 1984, Water levels and water-level changes in the Prairie du Chien-Jordan and Mount Simon-Hinckley aquifers, Twin Cities Metropolitan Area, Minnesota, 197180: U.S. Geological Survey Water-Resources Investigations Report 83-4237, 23 p.

Schoenberg, M.E., 1990, Effects of present and projected ground-water withdrawals on the Twin Cities aquifer system, Minnesota: U.S. Geological Survey Water-Resources Investigations Report 90-4001, 165 p.

Setterholm, D., 1991, Lake level controls and pumpingWhite Bear Lake: Report to White Bear Lake Conservation District. 
Short Elliott Hendrickson Inc., 2012, Part I, Wellhead protection plan for the city of Mora, Minnesota: St. Paul, Minnesota, SHE No. MORA 109696, 71 p., accessed December 28, 2012, at http://www.ci.mora.mn.us/ vertical/sites/\%7B10E9A731-228C-4FE8-9EA3018C1162BBAE\%7D/uploads/MoraPartI_complete.pdf.

Swanson, L., and Meyer, G.N., 1990, Geologic atlas of Washington County, Minnesota: Minnesota Geologic Survey County Atlas Series C-5, accessed January 19, 2012, at http://purl.umn.edu/58492.

Thayer, C.A, 1883, Indian legends of Minnesota: Boston, Massachusetts, J.R. Osgood and Company, p. 583-593.

University of Minnesota, National Lacustrine Core Facility, 2012, LacCore standard lake-sediment coring sampling procedures: accessed May 15, 2012, at http://lrc.geo.umn. edu/laccore/assets/pdf/sops/livingstone-bolivia.pdf.

U.S. Census Bureau, 2012, 2010 population finder: U.S. Department of Commerce, accessed July 6, 2012, at http://www.census.gov/popfinder/.

U.S. Environmental Protection Agency, 1997, State source water assessment and protection programs final guidance: Washington, D.C., U.S. Environmental Protection Agency EPA 816-R-97-009, appendix D.

U.S. Environmental Protection Agency, 2005, Long Term 2 Enhanced Surface Water Treatment Rule: U.S. Environmental Protection Agency Fact Sheet EPA 815-F-05-002, 4 p.

U.S. Fish \& Wildlife Service, 1994, National wetlands inventory digital data, October 1991 to 1994: accessed January 17, 2013, at $h t t p: / / w w w . f w s . g o v / w e t l a n d s$.

U.S. Geological Survey, variously dated, National field manual for the collection of water-quality data: U.S. Geological Survey Techniques of Water-Resources Investigations, book 9, chaps. A1-A9, accessed December 28, 2012, at http://pubs.water.usgs.gov/twri9A.

U.S. Geological Survey, 2012, U.S. Geological Survey National Water Information System, Water Data for Minnesota—Web Interface: accessed July 6, 2012, at http:// waterdata.usgs.gov/mn/nwis/nwis.

Walsh, J.F., 2007, Wellhead protection plan for the city of Coleraine, Minnesota, part 1: Minnesota Department of Health, $40 \mathrm{p}$.

Webb, R. S., and Webb, T., III, 1988, Rates of accumulation in pollen cores from small lakes and mires of eastern North America: Quaternary Research, v. 30, p. 284-297. (Also available at $h t t p: / / d x . d o i . o r g / 10.1016 / 0033-$ 5894(88)90004-X)
Wetzel, R.G., 1983, Limnology (2d ed.): Philadelphia, Pa., Saunders College Publishing, p. 73-213.

Winter, T.C., 1981, Uncertainties in estimating the water balance of lakes: Journal of the American Water Resources Association, v. 17, p. 82-115.

Winter, T.C., Harvey, J.W., Franke, O.L., and Alley, W.M., 1998, Ground water and surface water-A single resource: U. S. Geological Survey Circular 1139, p. 46-49. (Also available at http://pubs.usgs.gov/circ/circ1139/.)

Winter, T.C., and Pfannkuch, H.O., 1976, Hydrogeology of a drift-filled bedrock valley near Lino Lakes, Anoka County, Minnesota: Journal of Research of U.S. Geological Survey, 1976, v. 4, no. 3, p. 267-276. (Also available at http://pubs. usgs.gov/journal/1976/vol4issue3/report.pdf.)

Winter, T.C., and Rosenberry, D.O., 2009, Evaluation of methods and uncertainties in the water budget, in Winter, T.C., and Likens, G.E., eds., Mirror Lake-Interactions among air, land, and water: Berkeley, California, University of California Press, Freshwater Ecology Series, p. 205-224.

Winter, T.C., LaBaugh, J.W., and Rosenberry, D.O., 1988, The design and use of a hydraulic potentiomanometer for direct measurement of differences in hydraulic head between groundwater and surface water: Limnology and Oceanography, v. 33, no. 5, p. 1,209-1,214.

Winter, T.C., Rosenberry, D.O., and LaBaugh, J.W., 2003, Where does the ground water in small watersheds come from?: Ground Water, v. 41, no. 7, p. 989-1,000. (Also available at $h t t p: / / d x$.doi.org/10.1111/j.1745-6584.2003. tb02440.x.)

Woessner, W.W., and Sullivan, K.E., 1984, Results of seepage meter and mini-piezometer study, Lake Mead, Nevada: Ground Water, v. 22, no. 5, p. 561-568. (Also available at http://dx.doi.org/10.1111/j.1745-6584.1984.tb01425.x.)

Wright, H.E., Jr. 1967, A square-rod piston sampler for lake sediments: Journal of Sedimentary Research, v. 37, no. 3, p. 975-976.

Zamora, Celia, 2006, Estimates of vertical flux across the sediment-Water interface by direct measurement and using temperature as a tracer in the Merced River, California: Sacramento, California, California State University, Master's thesis, $90 \mathrm{p}$. 


\section{Appendix Tables}


Table 1-1. Summaries of analysis of covariance (ANCOVA) models (significant at an alpha of 0.05) used for estimating annual lakelevel changes for White Bear Lake, northeast Twin Cities Metropolitan Area, Minnesota.

$\left[\mathrm{R}^{2}\right.$, coefficient of determination; $<$, less than $]$

\begin{tabular}{|c|c|c|c|c|c|c|c|c|}
\hline $\begin{array}{l}\text { Model }^{1} \\
\text { number }\end{array}$ & $\begin{array}{l}\text { Lake- } \\
\text { level change } \\
\text { source }\end{array}$ & $\begin{array}{c}\text { Continuous } \\
\text { explanatory } \\
\text { variable }\end{array}$ & $\begin{array}{c}\text { Model ad- } \\
\text { justed } \text { R }^{2}\end{array}$ & $\begin{array}{l}\text { Model residual } \\
\text { standard error }\end{array}$ & Coefficient & Value & $\begin{array}{l}\text { Standard } \\
\text { error }\end{array}$ & $p$-value \\
\hline \multirow{3}{*}{1} & \multirow{3}{*}{$\begin{array}{l}\Delta L W ; \text { annual } \\
\text { change } \\
1978-2011\end{array}$} & \multirow{3}{*}{$\begin{array}{c}P ; \text { High-density, } \\
\text { nearest, best } \\
\text { available }^{2}\end{array}$} & \multirow{3}{*}{0.76} & \multirow{3}{*}{0.42} & $b_{0}$ & -4.0 & 0.44 & $<0.0001$ \\
\hline & & & & & $b_{1}$ & 0.12 & 0.01 & $<0.0001$ \\
\hline & & & & & $b_{2}$ & -0.5 & 0.17 & 0.004 \\
\hline \multirow{3}{*}{2} & \multirow{3}{*}{$\begin{array}{l}\Delta L W+\mathrm{SO} \\
\quad \text { annual } \\
\text { change } \\
1978-2011\end{array}$} & \multirow{3}{*}{$\begin{array}{l}P-E \text {; High- } \\
\text { density, } \\
\text { nearest, best } \\
\text { available }^{2}\end{array}$} & \multirow{3}{*}{0.83} & \multirow{3}{*}{0.38} & $b_{0}$ & -0.3 & 0.09 & 0.001 \\
\hline & & & & & $b_{1}$ & 0.10 & 0.009 & $<0.0001$ \\
\hline & & & & & $b_{2}$ & -0.7 & 0.15 & $<0.0001$ \\
\hline \multirow{3}{*}{3} & \multirow{3}{*}{$\begin{array}{l}\Delta L W ; \text { annual } \\
\text { change } \\
1978-2011\end{array}$} & \multirow{3}{*}{$\begin{array}{l}P \text {; High-density } \\
\text { single long- } \\
\text { term observer }^{3}\end{array}$} & \multirow{3}{*}{0.64} & \multirow{3}{*}{0.52} & $b_{0}$ & -4.4 & 0.65 & $<0.0001$ \\
\hline & & & & & $b_{1}$ & 0.13 & 0.019 & $<0.0001$ \\
\hline & & & & & $b_{2}$ & -0.7 & 0.20 & 0.003 \\
\hline \multirow{3}{*}{4} & \multirow{3}{*}{$\begin{array}{l}\Delta L W ; \text { annual } \\
\text { change } \\
1978-2011\end{array}$} & \multirow{3}{*}{$\begin{array}{l}P \text {; Wetland } \\
\quad \text { delineation } \\
\text { source }^{4}\end{array}$} & \multirow{3}{*}{0.73} & \multirow{3}{*}{0.45} & $b_{0}$ & -4.6 & 0.55 & $<0.0001$ \\
\hline & & & & & $b_{1}$ & 0.14 & 0.02 & $<0.0001$ \\
\hline & & & & & $b_{2}$ & -0.4 & 0.18 & 0.054 \\
\hline
\end{tabular}

${ }^{1}$ Form for model numbers 1, 3, and 4: $\Delta L W=b_{0}+\left(b^{l} \times P\right)+\left(b_{2} \times T_{p}\right)+\varepsilon$; model number 2: $(\Delta L W+S O)=b_{0}+\left[b_{1} \times(P-E)\right]+\left(b_{2} \times T_{p}\right)+\varepsilon$, where $\Delta L W=$ annual lake-level change between January 1 and December 31 of a calendar year, in feet; $P=$ precipitation on lake surface, in inches; $E=$ pan-estimated evaporation from lake surface, in inches; $T_{p}=$ time-period binary variable, equal to 0 for 1978-2002 and equal to 1 for 2003-11; $S O=$ surface-water outflow, in feet of lake level; $\varepsilon=$ random error (residual) in feet; $b_{i}=$ estimated coefficients where $b_{0}=$ intercept, in feet; $b_{1}=$ slope coefficient for continuous explanatory variable, in feet per inch; and $b_{2}=$ coefficient indicating the intercept difference between 1978-2002 and 2003-11, in feet.

${ }^{2}$ Minnesota Climatology Working Group, 2011a.

${ }^{3}$ Peter Boulay, Minnesota Department of Natural Resources, written commun., January 13, 2012.

${ }^{4}$ Minnesota Climatology Working Group, 2012a. 
Table 1-2. Summaries of analysis of covariance (ANCOVA) models (significant at an alpha of 0.05) used for estimating annual or seasonal lake-volume changes for White Bear Lake, northeast Twin Cities Metropolitan Area, Minnesota.

$\left[\mathrm{R}^{2}\right.$, coefficient of determination; $<$, less than $]$

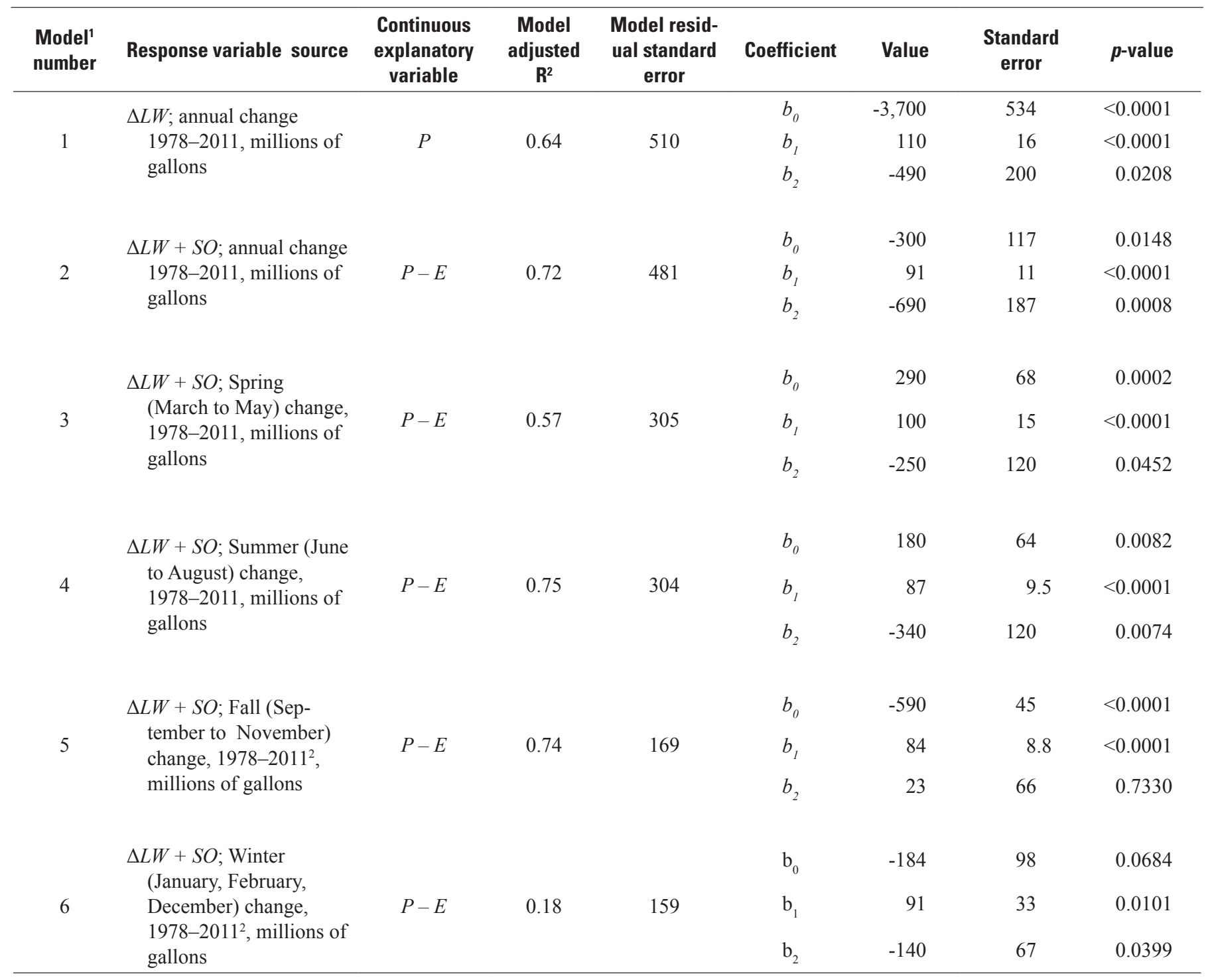

${ }^{1}$ Form for model number $1: \Delta L W=b_{0}+\left(b_{1} \times P\right)+\left(b_{2} \times T_{p}\right)+\varepsilon$; models 2-6: $(\Delta L W+S O)=b_{0}+\left[b_{1} \times(P-E)\right]+\left(b_{2} \times T_{p}\right)+\varepsilon$, where $\Delta L W=$ lake-volume change, in millions of gallons; $P=$ precipitation on lake surface, in inches; $E=$ pan-estimated evaporation from lake surface, in inches; $T_{p}=$ time period binary variable, equal to 0 for 1978-2002 and equal to 1 for 2003-11; $S O=$ surface-water outflow, in millions of gallons; $\varepsilon=$ random error (residual) in millions of gallons; $b_{i}=$ estimated coefficients where $\mathrm{b}_{0}=$ intercept, in millions of gallons; $b_{1}=$ slope coefficient for continuous explanatory variable, in millions of gallons per inch; and $b_{2}=$ coefficient indicating the intercept difference between 1978-2002 and 2003-11, in millions of gallons.

${ }^{2} 1984$ data were excluded because the outflow was blocked (Minnesota Department of Natural Resources, 1998). 
Table 1-3. Summaries of multiple linear regression models (significant at an alpha of 0.05) used for estimating annual changes in level or volume of White Bear Lake and estimating annual and seasonal groundwater withdrawals from the Prairie du Chien-Jordan aquifer in the northeast Twin Cities Metropolitan Area, Minnesota.

$\left[\mathrm{R}^{2}\right.$, coefficient of determination; Mgal, millions of gallons; $<$, less than $]$

\begin{tabular}{|c|c|c|c|c|c|c|c|c|c|}
\hline Model form ${ }^{1}$ & $\begin{array}{l}\text { Model } \\
\text { number }\end{array}$ & Model description' & $\begin{array}{l}\text { Adjusted } \\
\mathbf{R}^{2}\end{array}$ & $\begin{array}{l}\text { Model resid- } \\
\text { ual standard } \\
\text { error }\end{array}$ & $\begin{array}{c}\text { Coeffi- } \\
\text { cient }\end{array}$ & $\begin{array}{l}\text { Coefficient } \\
\text { units }\end{array}$ & Value & $\begin{array}{l}\text { Standard } \\
\text { error }\end{array}$ & $p$-value \\
\hline \multirow{7}{*}{$\begin{array}{c}(\Delta L W+S O)=b_{0}+\left[b_{1} \times(P-E)\right]+ \\
\left(b 2 \times W_{P D C J}\right)+\varepsilon\end{array}$} & \multirow{3}{*}{1} & \multirow{3}{*}{$\begin{array}{l}\text { Annual, 1980-2010, all } \\
\text { variables in millions of } \\
\text { gallons }\end{array}$} & \multirow{4}{*}{0.72} & \multirow{3}{*}{496} & $b_{0}$ & Mgal & 710 & 402 & 0.088 \\
\hline & & & & & $b_{1}$ & Mgal/Mgal & 1.4 & 0.17 & $<0.0001$ \\
\hline & & & & & $b_{2}$ & Mgal & -0.37 & 0.12 & 0.004 \\
\hline & \multirow{4}{*}{2} & \multirow{4}{*}{$\begin{array}{c}\text { Annual, } 1980-2010, \triangle L W \text { in } \\
\text { feet, } S O \text { in feet, } P-E \text { in } \\
\text { inches, } W_{P D C J} \text { in millions } \\
\text { of gallons }\end{array}$} & & & & & & & \\
\hline & & & \multirow{3}{*}{0.82} & \multirow{3}{*}{0.40} & $b_{0}$ & feet & 0.85 & 0.033 & 0.015 \\
\hline & & & & & $b_{1}$ & feet/inch & 0.099 & 0.009 & $<0.0001$ \\
\hline & & & & & $b_{2}$ & Mgal & $-4.3 E-4$ & 0 & 0 \\
\hline \multirow{15}{*}{$W_{P D C J}=b_{0}+\left(b_{1} \times Y\right)+\left(b_{2} \times P\right)+\varepsilon$} & \multirow{3}{*}{3} & \multirow{3}{*}{$\begin{array}{l}\text { Annual, } 1980-2010, Y \text { in } \\
\text { years, } P \text { in inches, } W_{P D C J} \\
\text { in millions of gallons }\end{array}$} & \multirow{3}{*}{0.91} & \multirow{3}{*}{230.90} & $b_{0}$ & Mgal & $-159,000$ & 9,280 & $<0.0001$ \\
\hline & & & & & $b_{1}$ & Mgal/year & 82 & 4.66 & $<0.0001$ \\
\hline & & & & & $b_{2}$ & Mgal/inch & -25 & 7.1 & 0.001 \\
\hline & \multirow{3}{*}{4} & \multirow{3}{*}{$\begin{array}{c}\text { Spring (March, April, May), } \\
\text { 1988-2010, } Y \text { in years, } P \\
\text { in inches, } W_{P D C J} \text { in mil- } \\
\text { lions of gallons }\end{array}$} & \multirow{3}{*}{0.70} & \multirow{3}{*}{63.25} & $b_{0}$ & Mgal & $-24,700$ & 3,990 & $<0.0001$ \\
\hline & & & & & $b_{1}$ & Mgal/year & 13 & 1.99 & $<0.0001$ \\
\hline & & & & & $b_{2}$ & Mgal/inch & -12 & 4.3 & 0.008 \\
\hline & \multirow{3}{*}{5} & \multirow{3}{*}{$\begin{array}{l}\text { Summer (June, July, Au- } \\
\text { gust), 1988-2010, } Y \text { in } \\
\text { years, } P \text { in inches, } W_{P D C J} \\
\text { in millions of gallons }\end{array}$} & \multirow{3}{*}{0.77} & \multirow{3}{*}{159.20} & $b_{0}$ & Mgal & $-72,000$ & 10,000 & $<0.0001$ \\
\hline & & & & & $b_{1}$ & Mgal/year & 37 & 5.01 & $<0.0001$ \\
\hline & & & & & $b_{2}$ & Mgal/inch & -32 & 7.0 & 0 \\
\hline & \multirow{3}{*}{6} & \multirow{3}{*}{$\begin{array}{l}\text { Fall (September, October, } \\
\text { November), 1988-2010, } Y \\
\text { in years, } P \text { in inches, } W_{P-} \\
\quad \text { in millions of gallons }\end{array}$} & \multirow{3}{*}{0.69} & \multirow{3}{*}{77.55} & $b_{0}$ & Mgal & $-33,700$ & 4,900 & $<0.0001$ \\
\hline & & & & & $b_{1}$ & Mgal/year & 17 & 2.5 & $<0.0001$ \\
\hline & & & & & $b_{2}$ & Mgal/inch & -12 & 5.8 & 0.059 \\
\hline & \multirow{3}{*}{7} & \multirow{3}{*}{$\begin{array}{l}\text { Winter (January, February, } \\
\text { December), 1988-2010, } Y \\
\text { in years, } P \text { in inches, } W_{P-} \\
\text { in millions of gallons }\end{array}$} & \multirow{3}{*}{0.59} & \multirow{3}{*}{32.84} & $b_{0}$ & Mgal & 12,300 & 2,440 & 0 \\
\hline & & & & & $b_{1}$ & Mgal/year & 6 & 1.2 & $<0.0001$ \\
\hline & & & & & $b_{2}$ & Mgal/inch & -8 & 8.90 & 0.390 \\
\hline
\end{tabular}

${ }^{1}$ Variables are defined as $\Delta L W=$ annual change in White Bear Lake volume or level; $S O=$ surface-water outflow; $P=$ precipitation on lake surface; $E=$ pan-estimated evaporation from lake surface;

$W_{P D C J}=$ groundwater withdrawals from the Prairie du Chien-Jordan aquifer in the vicinity of White Bear Lake; $Y=$ year; $b_{i}=$ coefficient estimated in regression, $\varepsilon=$ random error (residual). 
Table 1-4. Analysis of variance (ANOVA) table comparing the sequential addition of explanatory variables used to explain annual lake-volume change, White Bear Lake, northeast Twin Cities Metropolitan Area, Minnesota, 1980-2010.

$[<$, less than; --, no data $]$

\begin{tabular}{lcrrrr}
\hline $\begin{array}{c}\text { Model } \\
\text { variable }\end{array}$ & $\begin{array}{c}\text { Degrees } \\
\text { of } \\
\text { freedom }\end{array}$ & $\begin{array}{c}\text { Sum of } \\
\text { squared } \\
\text { errors }\end{array}$ & $\begin{array}{c}\text { Mean } \\
\text { squared } \\
\text { error }\end{array}$ & F-value & p-value \\
\hline$P-E$ & 1 & $17,100,000$ & $17,100,000$ & 72.9 & $<0.0001$ \\
$W_{P D C J}$ & 1 & $2,500,000$ & $2,500,000$ & 10.7 & 0.003 \\
$T_{p}$ & 1 & 665,000 & 665,000 & 2.84 & 0.105 \\
$(P-E) \times T_{p}$ & 1 & 355,000 & 355,000 & 1.51 & 0.230 \\
$W_{P D C J} \times T p$ & 1 & 18 & 18 & 0 & 0.993 \\
Residuals & 25 & $5,860,000$ & 234,000 & -- & -- \\
\hline
\end{tabular}

${ }^{1}$ Statistical model: $(\Delta L W+S O)=\left[(P-E)+W_{P D C J}\right] \times T_{p}$ where $\Delta L W=$ annual lake volume change, in millions of gallons; $S O=$ annual surface-water outflow volume, in millions of gallons; $P=$ annual precipitation volume on lake surface, in millions of gallons; $E$ = annual evaporation volume from lake-surface, in millions of gallons; $W_{P D C J}=$ annual groundwater withdrawal volume from the Prairie du Chien-Jordan aquifer, in millions of gallons; $T_{p}=$ time period binary variable, equal to 0 for 1978-2002 and equal to 1 for 2003-11.

Table 1-5. Groundwater-level data collected during synoptic studies in March/April 2011, northeast Twin Cities Metropolitan Area, Minnesota. The Excel file may be downloaded from http://pubs.usgs.gov/sir/2013/5044/downloads/table_1-5.xlsx.

Table 1-6. Groundwater-level data collected during synoptic studies in August 2011, northeast Twin Cities Metropolitan Area, Minnesota. The Excel file may be downloaded from http://pubs.usgs.gov/sir/2013/5044/downloads/table_1-6.xlsx.

Table 1-7. Surface-water-level data collected by Minnesota Department of Natural Resources during synoptic studies in March/April 2011, northeast Twin Cities Metropolitan Area, Minnesota. The Excel file may be downloaded from http://pubs.usgs.gov/sir/2013/5044/ downloads/table_1-7.xlsx.

Table 1-8. Surface-water-level data collected by Minnesota Department of Natural Resources during synoptic studies in August 2011, northeast Twin Cities Metropolitan Area, Minnesota. The Excel file may be downloaded from http://pubs.usgs.gov/sir/2013/5044/ downloads/table_1-8.xlsx.

Table 1-9. Temperature measurements made in surface water and lake sediment of White Bear Lake, northeast Twin Cities Metropolitan Area, Minnesota, July through August 2011. The Excel file may be downloaded from http://pubs.usgs.gov/sir/2013/5044/ downloads/table_1-9.xlsx.

Table 1-10. Seepage flux measurements and hydraulic-head measurements on the shore of White Bear Lake, northeast Twin Cities Metropolitan Area, Minnesota, 2011. The Excel file may be downloaded from http://pubs.usgs.gov/sir/2013/5044/downloads/table_1-10. $x l s x$. 
Publishing support provided by:

Rolla Publishing Service Center

For more information concerning this publication, contact: Director, USGS Minnesota Water Science Center 2280 Woodale Drive

Mounds View, Minnesota 55112

(763) 783-3100

Or visit the Minnesota Water Science Center Web site at: http://mn.water.usgs.gov/ 

